\title{
Liga Kroniņa
}

\section{BËRNU BAILES UN TRAUKSME ZOBĀRSTNIECĪBĀ UN TO SAISTİBA AR MUTES VESELİBU UN PSIHOSOCIĀLAJIEM FAKTORIEM}

Promocijas darbs medicinnas doktora zinātniskā grāda iegūšanai Specialitāte - zobārstniecība 


\title{
Līga Kroniña
}

\section{BĒRNU BAILES UN TRAUKSME ZOBĀRSTNIECĪBĀ UN TO SAISTİBA AR MUTES VESELĪBU UN PSIHOSOCIĀLAJIEM FAKTORIEM}

\author{
Promocijas darbs \\ medicīnas doktora zinātniskā grāda iegūšanai \\ Specialitāte - zobārstniecība \\ Darba zinātniskās vadītājas: \\ Dr. med. profesore Rūta Care \\ Dr. psych. profesore Malgožata Raščevska
}




\begin{abstract}
ANOTĀCIJA
Darbs veltīts bērnu baiļu un trauksmes izpētei zobārstniecībā, to iemesliem un sekām. Mūsdienās, neskatoties uz modernās zobārstniecības tehnoloǵijām (lāzeru, ozonu, ultraskaņu, sedāciju, Wand un vispārējo anestēziju), joprojām saglabājas augsts baiḷu no zobārsta līmenis, īpaši bērniem. Tāpēc bailes no zobārsta ir aktuāls temats daudzās bērnu zobārstniecības konferencēs un kongresos, meklējot gan cēloṇus, gan saistību ar dažādiem faktoriem, gan veidus, kā labāk pārvarēt bailes. Latvijā šādi pētījumi līdz šim nav veikti. Šì darba mērkis bija izpētīt bērnu bailes no zobārsta, to cēloņus, saistītos faktorus un arī sekas mutes veselībai, ko atstāj bailes no zobārsta. Teorētiskajā daḷā tika precizēti dažādi iekšēji un ārēji cēloṇi, kas varētu būt saistīti ar bērnu bailēm no zobārsta, tai skaitā bērna personība, vecāku bailes no zobārsta, ǵimenes stress, sociālekonomiskie faktori. Tāpat teorētiskajā dậā tika precizēti ārējie cēloṇi, kas saistās ar bērnu iepriekšējo pieredzi un attieksmi pret zobārstiem, ārstiem un zobu kopšanu.
\end{abstract}

Pētījumā tika parādīta baiļu no zobārsta saistība ar dažādiem psihosociālajiem faktoriem. Bailes no zobārsta lielā mērā izskaidroja bērna zobārstniecības pieredze, īpaši sāpes un/vai nepatīkama attieksme no medicīnas personāla puses. Savukārt tādi bērna personības faktori kā vispārējā trauksme un citu, ar zobārstniecību nesaistītu baiḷu skaits, bet jo īpaši attieksme pret ārstiem un zobārstiem, un bērna uzvedība zobārsta kabinetā bija īpaši cieši saistīta ar bērna bailēm no zobārsta. Tāpat liela nozīme bija vecāku attieksmei pret zobārstu (bailēm) un veidam, kādā informācija par zobiem tiek nodota bērnam, un bērna medicīniskajai pieredzei, piemēram, biežiem ārstu apmeklējumiem un traumatiskai pieredzei pie ārstiem, izņemot zobārstus. Nedaudz mazāk bailes no zobārsta izskaidroja ǵimenes sociālekonomiskie/demogrāfiskie faktori, piemēram bērnu, ġimenes locekḷu un mājsaimniecībā dzīvojošo locekḷu lielāks skaits bija saistīts ar zemākām bailēm no zobārsta. Nelielā mērā bērnu bailes no zobārsta bija saistītas arī ar izmainītiem mutes kopšanas paradumiem, piemēram, bērni nelabprāt tīrīja zobus. Ģimenes stresa faktori nebija saistīiti ar bērnu bailēm no zobārsta.

Tomēr viens no būtiskākajiem rezultātiem bija konstatētā saistība starp bērnu bailēm no zobārsta un kariozo zobu skaitu visos sakodiena veidos, kā arī ar vēlāku pirmo apmeklējumu (apskati). Tas parāda, ka bailes no zobārsta ir cieši saistītas ar sliktāku mutes veselību, jo tās attur bērnus un viṇu vecākus savlaicīgi vērsties pie zobārsta. Savukārt, saņemot konsultāciju par zobu veselības jautājumiem, būtu iespējams gan uzlabot zobu veselību, gan samazināt bērnu bailes no zobārsta. 


\section{SUMMARY}

The study is aimed at investigation of the children's dental fear and anxiety, its causes and consequences. Nowadays, in spite of modern dental technologies (laser, ozone, ultrasound, sedation, Wand and general anaesthesia) a high level of dental fear, especially in children, still remains. Therefore, dental fear is a subject of broad and current interest in many paediatric dental conferences in search of both the causes thereof and connection with various factors leading to dental fear and ways for better coping with fear. Until now no such studies have been carried out in Latvia. The aim of this study was to investigate the children's dental fear, its causes, associated factors, and effects of dental fear on oral health. The theoretical part of the study covered description of various internal and external causes leading to the dental fear, including child personality, parents' dental fear, family stress, socio-economic factors. The theoretical part also showed external causes in regard to the children's previous experience with dentists, doctors and oral health.

The study showed relationship between dental fear and various psychosocial factors. Dental fear, to the great extent, can be explained by the child's dental experience, especially pain and/or harsh attitude on part of the medical staff. However, the child's personality factors such as general anxiety and the number of other non-dental fears, but especially attitudes towards doctors and dentists, and the child's behaviour in the dentist's office were particularly closely connected with the child's dental fear. Very important was also the parents' attitude towards the dentist (fear) and the way in which information on dental matters was transferred to the child, as well as the child's medical experience, for instance, frequent doctor appointments and traumatic experience with doctors, excluding dentists. Slightly less dental fear was explained by the family socio-economic/demographic factors, for example, the higher number of children, family members and household members was linked with the lower level of dental fear. To a small extent, the child's dental fear was associated with altered oral care habits, for example, children are reluctant to tooth brushing. Family stress factors were not related to the children's dental fear.

However, one of the most significant finding was the relationship between the children's dental fear and the number of decayed teeth in all types of bites, as well as late first appointment (examination). This shows that dental fear is closely associated with poorer oral health because it discourages children and their parents to make dentist appointment in time. Professional advice on dental health issues would allow improvement of dental health and reduction of the children's dental fear levels. 


\section{SATURS}

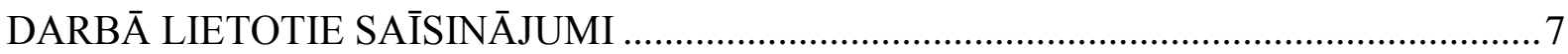

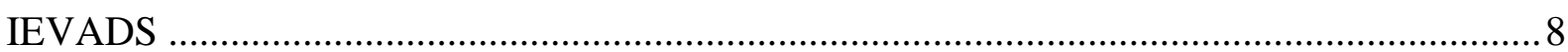

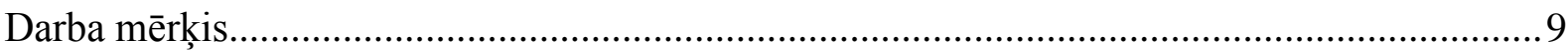

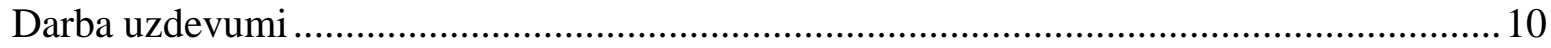

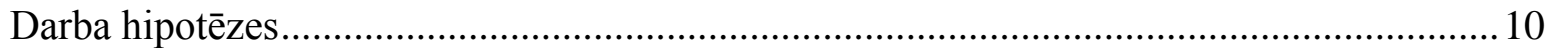

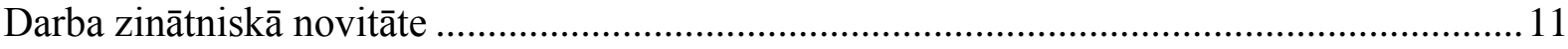

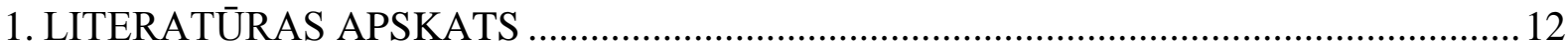

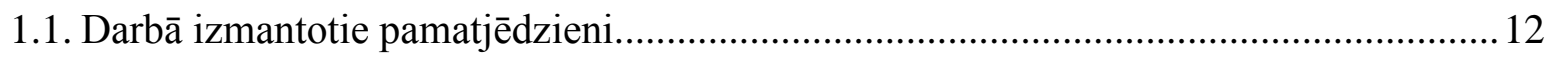

1.2. Baiḷu un trauksmes rašanās mehānismi (patoğenēze) ................................................13

1.3. Iekšējie (endogēnie, indivīdu raksturojošie) faktori, kas ietekmē BTZ .........................16

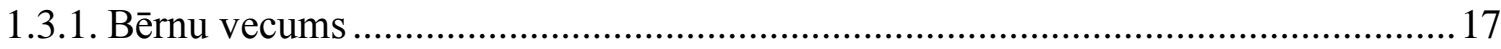

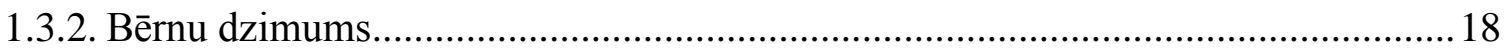

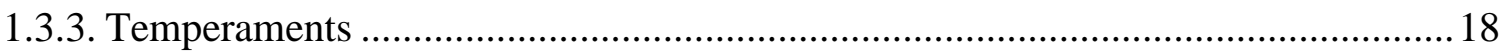

1.3.4. Vispārèjā trauksme un cita veida bailes ..............................................................20

1.3.5. Bērna uzvedības zobārsta kabinetā saistība ar bailēm no zobārsta ..........................21

1.4. Ārējie, ar zobārstniecību saistītie faktori, kas ietekmē BTZ ........................................22

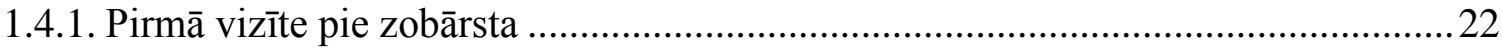

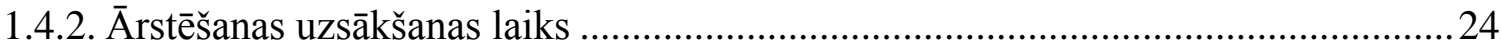

1.4.3. Negatīiva (traumatiska) pieredze pie zobārsta........................................................25

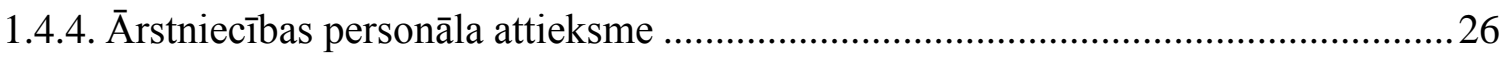

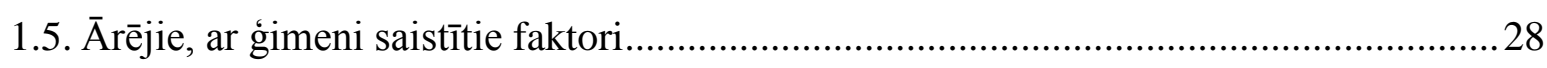

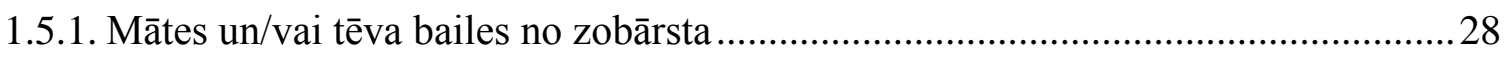

1.5.2. Vecāku sniegtā sagatavojošā informācija........................................................... 31

1.5.3. Stress ğimenē un tā pārvarēšanas veidi .....................................................................33

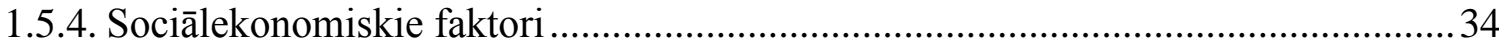

1.6. Ar bailēm no zobārsta un mutes veselību saistītie faktori ..........................................35

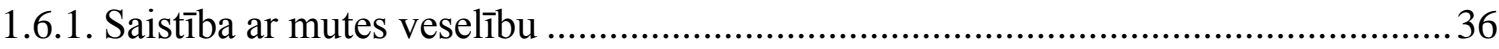

1.6.2. Saistība ar mutes dobuma kopšanas paradumiem ................................................... 38

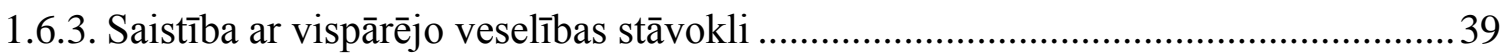

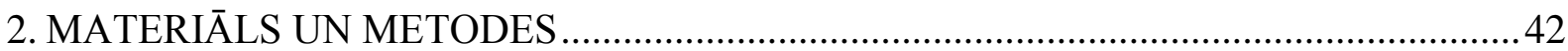

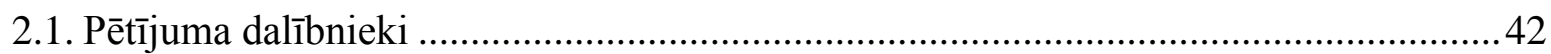

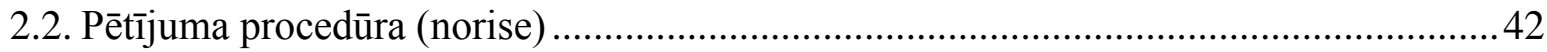

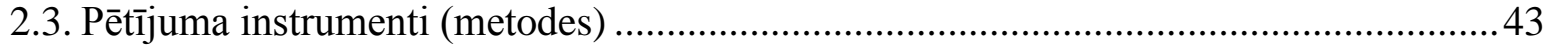

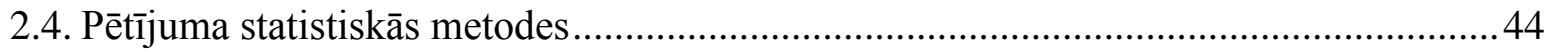




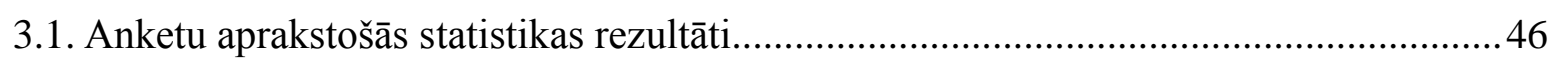

3.1.1. Bērnu baiḷu pārskata zobārstniecības skala (CFSS-DS), ticamība un validitāte ..... 46

3.1.2. Modificētā zobārstniecības trauksmes skala (MDAS) ...........................................47

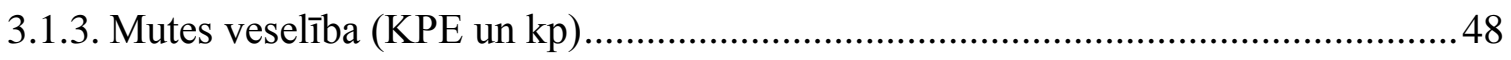

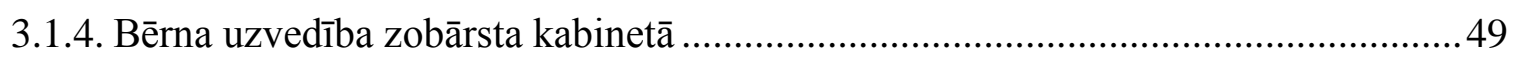

3.1.5. Anketa par bērna attieksmi pret zobārstu (dažādi psihosociālie faktori) .................50

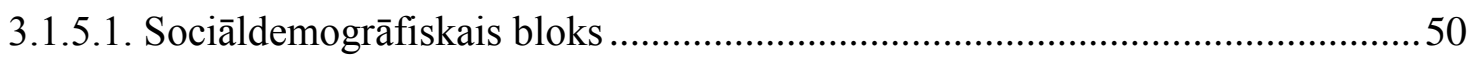

3.1.5.2. Bērna medicīniskās pieredzes un attieksmes bloks ......................................... 52

3.1.5.3. Zobārstniecības pieredzes un attieksmes bloks ............................................. 53

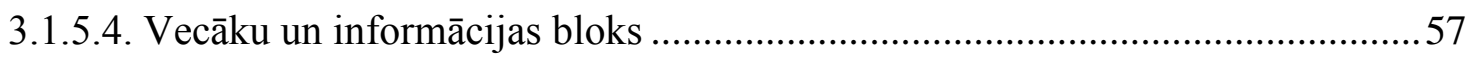

3.1.5.5. Zobu kopšanas paradumu un attieksmes bloks ............................................ 59

3.1.5.6. Bērna rakstura iezīmju un uzvedības bloks ................................................ 60

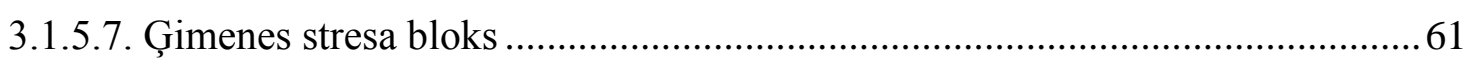

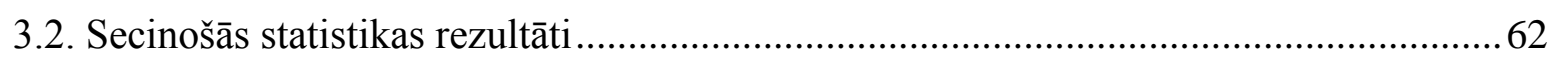

3.2.1. Bērnu bailes no zobārsta (BTZ), bērnu dzimums un vecums ................................ 62

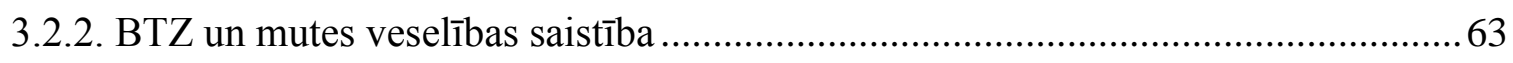

3.2.3. BTZ un bērna uzvedības zobārsta kabinetā saistība..............................................63

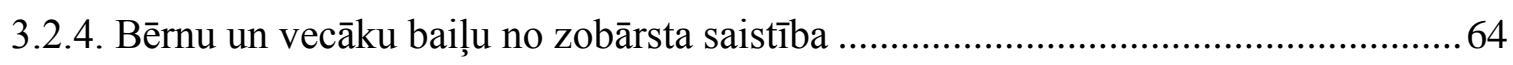

3.2.5. BTZ saistība ar dažādiem psihosociālajiem faktoriem .........................................64

3.2.5.1. Saistība ar sociālekonomiskajiem faktoriem ................................................ 64

3.2.5.2. Saistība ar bērnu medicīnisko pieredzi un attieksmi ....................................... 65

3.2.5.3. Saistība ar bērnu zobārstniecības pieredzi un attieksmi .................................66

3.2.5.4. Saistība ar vecāku un informācijas faktoriem.............................................67

3.2.5.5. Saistība ar bērnu zobu kopšanas paradumiem un attieksmi ............................. 70

3.2.5.6. Saistība ar bērnu personības un uzvedības faktoriem.................................... 70

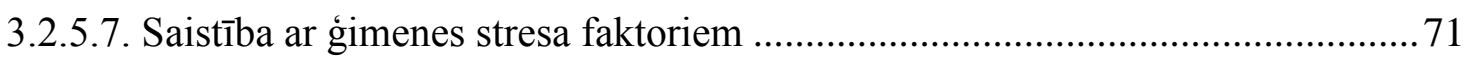

3.2.5.8. BTZ bērniem ar un bez negatīvas pieredzes pie zobārsta ............................... 72

3.2.6. Baiļu no zobārsta un psihosociālo faktoru regresijas analīze................................. 72

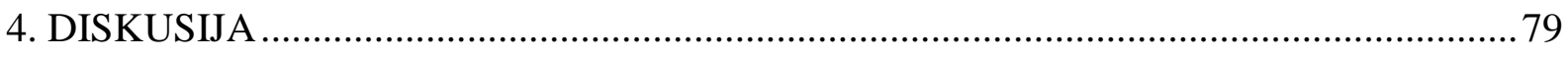

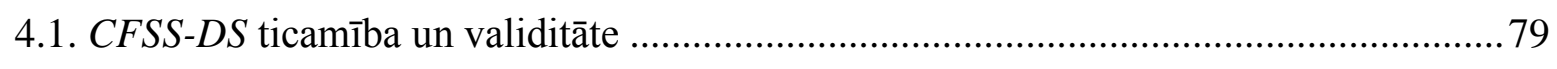

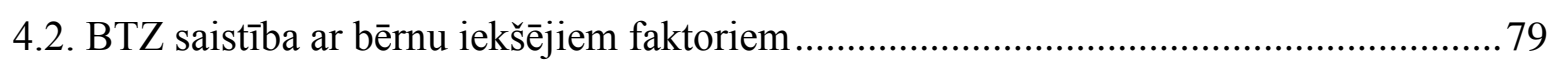

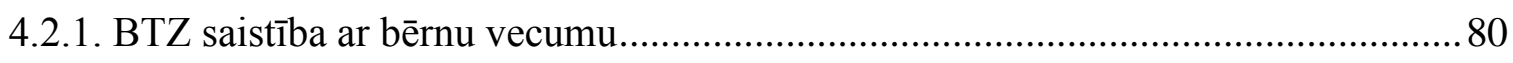

4.2.2. BTZ atšķirības starp dzimumiem ...................................................................... 80

4.2.3. BTZ saistība ar bērna temperamenta iezīmēm ................................................... 81

4.2.4. BTZ saistība ar bērna vispārējo trauksmi .............................................................. 81

4.2.5. BTZ saistība ar bērna citu baiḷu daudzumu ........................................................... 81 
4.2.6. BTZ saistība ar bērna uzvedību pie zobārsta...................................................... 82

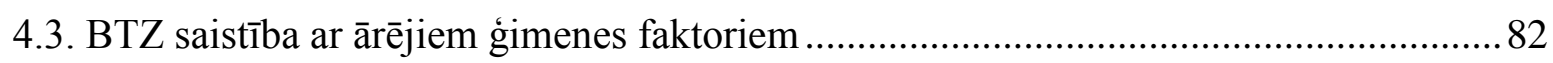

4.3.1. Bērnu un vecāku BTZ savstarpējā saistība.......................................................... 82

4.3.2. BTZ saistība ar vecāku saņemto un bērniem nodoto informāciju...........................84

4.3.3. BTZ saistība ar vecāku sociālekonomiskajiem rādītājiem ....................................85

4.4. BTZ saistība ar ārējiem zobārstniecības faktoriem................................................... 86

4.4.1. BTZ saistība ar bērna pirmo vizīti pie zobārsta (iemeslu un bērna vecumu)..........86

4.4.2. BTZ saistība ar iepriekšējo pieredzi pie zobārsta.................................................. 87

4.4.3. BTZ saistība ar bērnu traumatisku medicīnisko pieredzi .......................................8

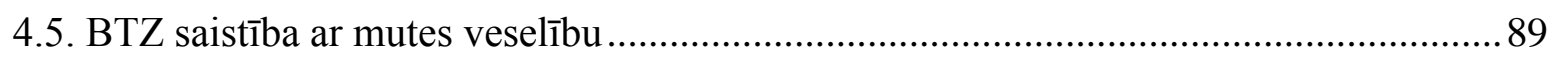

4.6. BTZ izskaidrojošo faktoru regresijas analīze. .........................................................90

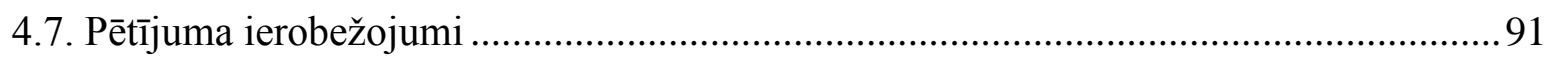

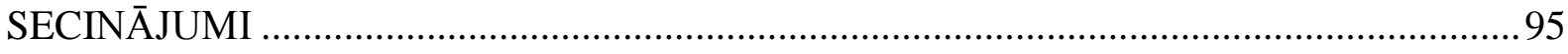

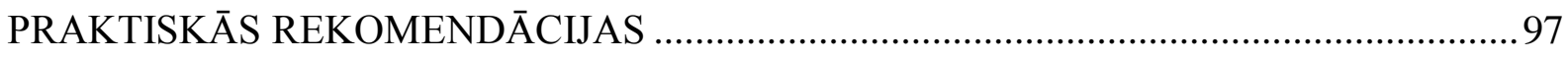

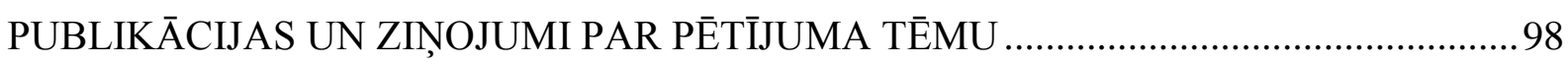

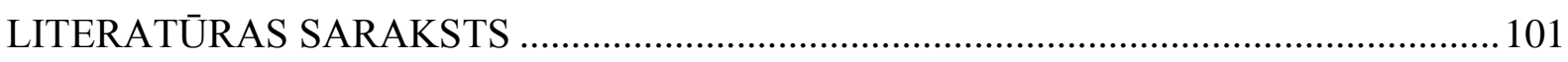

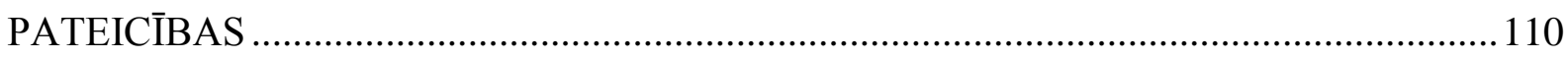

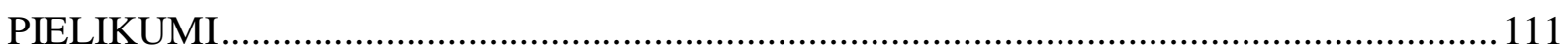




\section{DARBĀ LIETOTIE SĀ̄SINĀJUMI}

ANOVA analysis of variance (variāciju analīze)

ANCOVA analysis of covariance (kovariāciju analīze)

ANCOVA F kritērijs, rāda starpgrupu dispersijas attiecību pret iekšgrupas dispersiju

Beta $(\beta) \quad$ standartizēts regresijas koeficients (raksturo relatīvās vērtības)

B nestandartizēts regresijas koeficients (raksturo absolūtās vērtības)

BII blood-injury-injection phobia (fobija saistībā ar asinīm, ievainojumiem un/vai injekcijām

BTZ bailes un trauksme zobārstniecībā

CFSS-DS Children's Fear Survey Schedule-Dental Subscale (Bērnu baiḷu pārskata zobārstniecības skala)

CFSS-SF Children's Fear Survey Schedule-Short Form (Bērnu bailu pārskata īsā forma)

DFA dental fear and anxiety (bailes un trauksme zobārstniecībā)

DSM IV Diagnostic and Statistical Manual of Mental Disorders, 4th ed. (Garīgo traucējumu diagnostikas un statistikas rokasgrāmatas 4. izd.)

EASI Emotionality-Activity-Sociability-Impulsivity (temperamenta dimensijas: emocionalitāte, aktivitāte, sabiedriskums un impulsivitāte)

ICDAS International Caries Detection and Assessment System (Starptautiskā kariesa atklāšanas un novērtēšanas sistēma)

KPE kariozo, plombēto un ekstrahēto zobu skaits mutē

kp kariozo un plombēto piena zobu skaits mutē

kpe $\quad$ kariozo, plombēto un ekstrahēto piena zobu skaits mutē

M mean (vidējā vērtība)

MDAS Modified Dental Anxiety Scale (Modificētā zobārstniecības baiḷu skala)

N visas izlases respondentu skaits

n apakšizlases respondentu skaits

NP negatīva pieredze

OR odds ratio (varbūtības iespējamība)

p statistical significance (nozīmības līmenis)

PVO Pasaules Veselības organizācija

r korelācijas koeficients

$\mathrm{R}^{2} \quad$ daudzfaktoru korelācijas koeficienta kvadrāts

SD standartdeviation (standartnovirze)

SE standart-error (standartkḷūda)

t Stjūdenta $t$ testa vērtība 


\section{IEVADS}

Bailes no zobārsta visos laikos ir bijusi aktuāla tēma. Diemžēl, neskatoties uz 21. gadsimtā aizvien progresējošām tehnoloǵijām (lāzeru, ozonu, ultraskaņu, sedāciju, Wand un vispārējo anestēziju), bailes no zobārsta joprojām saglabājas, īpaši jaunākajā populācijas dạ̦ā - bērniem. Cilvēkiem bailes no zobārsta atstāj sekas visdažādākajās sfērās fiziologiskajā (svī̌sana, sausa mute, paātrināta sirdsdarbība), kognitīvajā (negatīvas domas, atmiņas, apziņas sašaurināšanās), uzvedības (izvairīšanās no zobārsta, noteiktu produktu ēšanas, noteiktu mediju un filmu skatīšanās), veselības (miega traucējumi, murgi, kā arī mutes veselības pasliktināšanās) un sociālajā (izvairīšanās veidot dziļākas attiecības profesionālajā un personiskajā dzīvē) sfērā (Cohen et al., 1985). Tā kā pacientu bailes un trauksme pie zobārsta nereti ietekmēja gan ārstēšanas kvalitāti, gan pacienta un zobārsta emocionālo labsajūtu, kopš pagājušā gadsimta vidus šai tēmai pakāpeniski sāka pievērst uzmanību gan zobārsti, gan psihologi (Morgan, 1940; Way, 1953; Tuma, 1954; Freidson \& Feldman, 1958; Frankl et al., 1962; Corah, 1969; Kleinknecht et al., 1978, u. c.). Šajā laikā parādījās pirmie raksti un pētījumi par iespējamiem iemesliem, kas varētu izraisīit bailes un trauksmi pie zobārsta, kā arī tika izstrādātas metodes to novērtēšanai (Frankl et al., 1962; Corah, 1969; Kleinknecht et al., 1978).

Pēdējās desmitgadēs izpētīta baiḷu no zobārsta saistība ar visdažādākajiem bērnu un pieaugušo iekšējiem faktoriem, piemēram, bērna vecumu un dzimumu (Winer, 1982; Klingberg \& Broberg, 2007), bērna uztveri un domām ārstēšanas laikā (Carillo-Diaz et al., 2012), sāpju uztveri (McNeil et al., 2011), citām specifiskām bailēm (Berggren, 1992; Klingberg et al., 1995) un jūtīgumu/ ievainojamību (Armfield et al., 2008), trauksmi kā personības iezīmi (Fuentes et al., 2009), bērna temperamentu (Arnrup et al., 2007), bērna uzvedību pie zobārsta (Klingberg et al., 1994), bērna baiļu pārvarēšanas stratēǵijām pie zobārsta (Versloot et al., 2004), lokusa kontroli (Hittner \& Hemmo, 2009), pašvērtējumu (Schuurs et al., 1988), optimismu/pesimismu (Neverlien \& Backer Johnsen, 1991), neirotismu (Schuurs et al., 1986), saskarsmes problēmām (Klaasen et al., 2007), stresa līmeni (Alfayad \& Al-Hadithy, 2012), iedzimtību (Thomson et al., 2009; Ray et al., 2010). Tāpat pētīta baiḷu no zobārsta saistība ar ārējiem faktoriem, kas saistīti ar zobārstniecību, piemēram, ar zobārstniecības komandas uzvedību (Zhou et al., 2010), negatīvu pieredzi pie zobārsta (Locker et al., 1996), ar zobu sāpēm (van Wijk \& Hoogstraten, 2005), bērna pirmo vizīti pie zobārsta (Rantavuori et al., 2002), agrīnu zobu ārstēšanu (Locker et al., 1999). Daudz pētīta arī baiļu no zobārsta saistība ar ārējiem faktoriem, kas nav saistīit ar zobārstniecību, piemēram, vispārējām saslimšanām un biežu ārstēšanos slimnīcā (Wogelius et al, 2003, 
2009), pārdzīvotu vardarbību (Beaton et al., 2014), traumām (De Jongh et al., 2006), ar bērnu un vecāku bailēm (Themessl-Huber et al., 2010), sociāldemogrāfiskajiem faktoriem (Folayan et al., 2004), t.sk., izglītību (Pohjola, 2007) un ienākumu līmeni (Hittner \& Hemmo, 2009), pat bērnu audzināšanas un piesaistes stilu (Krikken et al., 2012) un brīvā laika daudzumu un vecāku dzīvošanu atsevišķi (Gustafsson et al., 2007). Visbeidzot, daudz ir pētīta baiļu no zobārsta saistība ar apmeklējumu regularitāti jeb izvairīšanos no zobārsta (Berggren et al., 1984; Armfield et al., 2007), samazinātu vizīšu skaitu pie zobārsta (Carillo-Diaz et al., 2012), kā arī mutes veselību un ar to saistīto dzīves kvalitāti (Cohen, 1985; Taani et al., 2005; Akbay-Oba et al., 2009; Beena, 2013).

Visbiežāk dažādu faktoru saistība ar bailēm no zobārsta pētīta vienkāršos korelatīvos pētījumos, ir nedaudzi pētījumi, kuros veikti dažu faktoru regresijas analīze (Klingberg et al., 1995; Milgrom et al., 1995; Majstorovič et al., 2001; Milsom et al., 2003; Suprabha et al., 2011; Paryab \& Hosseinbor, 2013), bet maz ir pētījumu par daudzu faktoru vienlaicīgu ieguldījumu baiḷu no zobārsta izskaidrošanā (Armfield et al., 2009), it sevišķi bērniem (Lee et al., 2008). Tāpēc šķita svarīgi pārbaudīt vienlaicīgu, multifaktoriālu saistību ar bērnu bailēm no zobārsta. Balstoties uz iepriekšminētajām publikācijām, tika attīstīta ideja par septiniem psihosociālo faktoru blokiem, kas varētu korelēt ar bailēm no zobārsta un izskaidrot to variāciju.

Latvijā līdz šim nav veikti kvalitatīivi pētījumi ne par bērnu, ne par pieaugušo baiļu un trauksmes līmeni un izplatību zobārstniecībā. Tikai dr. Sandras Bērziņas promocijas darbā par kariesa un periodonta patologiju izplatību bērniem un pusaudžiem Latvijā, aplūkojot skolēnu aptaujas datus, norādīts, ka galvenais iemesls, kas attur 11, 12, 13 un 15 gadus vecus bērnus no zobārsta apmeklējuma, ir bailes no sāpēm un ārstēšanas, un šādu atbildi ir snieguši 45\% no aptaujātajiem pusaudžiem (Bērzinga, 2004). Tāpat līdz šim Latvijā nav izpētīts, cik lielā mērā bērnu un vecāku bailes no zobārsta ietekmē mutes dobuma stāvokli un kādi psihosociālie faktori vispār izraisa bērniem bailes un trauksmi saistībā ar zobārstniecību Latvijā.

\section{Darba mērḳis}

Novērtēt bērnu bailes un trauksmi zobārstniecībā un to saistību ar mutes veselību un dažādiem psihosociālajiem faktoriem. 


\section{Darba uzdevumi}

1. Novērtēt bērnu baiḷu un trauksmes zobārstniecībā aptaujas (CFSS-DS, Bērnu baiḷu pārskata zobārstniecības skala) ticamību un validitāti dažādu bērnu vecumu grupu baiḷu no zobārsta analīzei Latvijā.

2. Novērtēt bērnu baiļu un trauksmes zobārstniecībā saistību ar bērna iekšêjiem (personības un uzvedības) faktoriem - vecumu, dzimumu, temperamentu, vispārējo trauksmi, ar zobārstniecību nesaistītu baiļu skaitu un uzvedību zobārstniecības situācijā.

3. Novērtēt bērnu baiḷu un trauksmes zobārstniecībā saistību ar ārējiem gimenes (vecāku/informācijas) faktoriem - vecāku bailēm un trauksmi zobārstniecībā, informāciju un bērna sagatavošanu zobārsta vizītei, kā arī vecāku sociālekonomiskajiem/sociāldemogrāfiskajiem rādītājiem.

4. Novērtēt bērna baiļu un trauksmes zobārstniecībā saistību ar ārējiem zobārstniecības faktoriem - bērna vecumu pirmās zobu apskates un pirmās zobu ārstēšanas laikā, iepriekšēju negatīvu pieredzi zobārstniecības situācijās, bērna traumatisku medicīnisku pieredzi.

5. Novērtēt saistību starp bērnu baiḷu un trauksmes līmeni zobārstniecībā un bērnu mutes veselību.

6. Novērtēt, kādi psihosociālie faktori visnozīmīgāk izskaidro bērnu bailes un trauksmi zobārstniecībā.

\section{Darba hipotēzes}

1. CFSS-DS (Bērnu baiḷu pārskata zobārstniecības skalas) latviešu versija ir ticama un valida aptauja bērnu baiḷu no zobārsta novērtēšanai.

2. Bērnu bailes no zobārsta ir saistītas ar bērna iekšējiem (personības un uzvedības) faktoriem - vecumu, dzimumu, temperamenta iezīmēm (aktivitāti, emocionalitāti un kautrīgumu), vispārējo trauksmi, ar zobārstniecību nesaistītu baiļu skaitu un uzvedību zobārstniecības situācijā.

3. Bērnu bailes no zobārsta ir saistītas ar ārējiem ğimenes (vecāku/informācijas) faktoriem vecāku baiḷu un trauksmes līmeni zobārstniecībā, informāciju un bērna sagatavošanu zobārsta vizītei, kā arī vecāku sociālekonomiskajiem/sociāldemogrāfiskajiem rādītājiem.

4. Bērnu bailes no zobārsta ir saistītas ar ārējiem zobārstniecības faktoriem - bērna vecumu pirmās zobu apskates un pirmās zobu ārstēšanas laikā, iepriekšēju negatīvu pieredzi 
zobārstniecības situācijās, bērna traumatisku medicīnisku pieredzi (ārstēšanās slimnīcā un/vai hroniskas saslimšanas).

5. Bērnu bailes un trauksme zobārstniecībā pozitīvi korelē ar kariozo un ekstrahēto zobu un virsmu skaitu un negatīvi korelē ar plombēto zobu un virsmu skaitu.

6. Bērna bailes no zobārsta dažādā mērā izskaidro bērna iepriekšējā zobārstniecības un medicīniskā pieredze un attieksme, bērna personības un uzvedības faktori, vecāku un informācijas faktori, sociālekonomiskie/sociāldemogrāfiskie faktori, zobu kopšanas paradumi un attieksme, kā arī ǵimenes stresa faktori.

\section{Darba zinātniskā novitāte}

1. Pirmo reizi Latvijā tika veikts plašs pētījums par bērnu bailēm no zobārsta, to saistību ar psihosociāliem faktoriem un mutes veselību.

2. Darba zinātniskā novitāte ir dažādu psihosociālo faktoru ieguldījuma izpēte bērnu bailēs no zobārsta.

3. Novitāte ir baiļu no zobārsta atšķirību līmeņa noteikšana saistībā ar konkrētiem vecāku sniegtiem paskaidrojumu veidiem bērniem pirms zobārsta vizītes. 


\section{LITERATŪRAS APSKATS}

\subsection{Darbā izmantotie pamatjēdzieni}

Bailes no zobārsta (angliski - dental fear) ir spontāna emocionāla reakcija uz vienu vai vairākiem konkrētiem kairinātājiem saistībā ar zobārstniecību (Klingberg \& Broberg, 2007). Trauksme saistībā ar zobārstniecību (angliski - dental anxiety) ir personas subjektīva izjūta, ka jebkurā brīdī var notikt kaut kas tik nepatīkams vai sāpīgs, ka viņš vai viṇa zaudēs kontroli. Trauksme nav saistīta ar konkrētu kairinātāju (Klingberg \& Broberg, 2007). Nereti literatūrā ir grūti izşksirt, vai konkrētajā situācijā runa ir par bailēm vai trauksmi, tāpēc, neskatoties uz atšķirīgajiem mehānismiem, šie jēdzieni var tikt apvienoti kā bailes un trauksme zobārstniecībā - BTZ (angliski - DFA) (Klingberg \& Broberg, 2007). Savukārt odontofobija (angliski - odontophobia, dental phobia) ir smags baiḷu no zobārsta paveids (iekḷauts psihisko traucējumu $D S M-I V$ ), kam raksturīga izteikta, pastāvīga reakcija uz specifiskiem kairinātājiem vai zobārstniecības situāciju kopumā un kas ietekmē un traucē indivīda ikdienas rutīnu un sabiedrisko dzīvi (Klingberg \& Broberg, 2007). Bērnu zobārstniecībā tiek runāts arī par uzvedības traucējumiem zobārsta kabinetā (angliski - dental behaviour management problems), kas var būt vai nebūt saistīti ar bailēm vai trauksmi zobārstniecībā (Klingberg \& Broberg, 2007).

Viens no visvairāk izmantotajiem instrumentiem bērnu baiļu no zobārsta noteikšanai un mērīšanai ir Bērnu baiļu pārskata zobārstniecības skala (angliski - Children Fear Survey Schedule-Dental Subscale jeb CFSS-DS (Cuthbert \& Melamed, 1982)). Savukārt pieaugušajiem baiļu no zobārsta līmenis tiek noteikts ar Modificēto zobārstniecības skalu (angḷu valodā Modified Dental Anxiety Scale jeb MDAS (Humphris et al., 1995)). Šajā darbā ērtības labad visbiežāk tika izmantoti starptautiskie apzīmējumi CFSS-DS un MDAS.

Kariesa raksturošanai tika lietots saīsinājums KPE vai kp, kur ar K tika apzīmēts kariozs pastāvīgais zobs, P - plombēts pastāvīgais zobs, E - ekstrahēts pastāvīgais zobs, $\mathrm{k}$ - kariozs piena zobs, p - plombēts piena zobs. Kk - visi kariozie zobi, Pp - visi plombētie zobi, KPE + kp - kopējais kariozo, plombēto un ekstrahēto zobu skaits piena, maiņas un pastāvīgajā sakodienā.

ICDAS (angliski - International Caries Detecting and Assessment System) ir kariesa novērtēšanas sistēma, kurā ar atsevišksiem simboliem tiek izcelti intakti zobi, zobi ar kariozu bojājumu emaljā, dentīnā vai pulpā, piena vai pastāvīgie zobi, kā arī ortodontiski ekstrahēti zobi (Ismail et al., 2007). 
Literatūras atlase par bailēm un trauksmi zobārstniecībā saistībā ar mutes veselību un dažādiem psihoemocionāliem faktoriem tika veikta vairāku gadu garumā, atlasot rakstus ar atslēgas vārdiem dental anxiety un dental fear interneta datu bāzēs Ebsco, PubMed, ScienceDirect, Wiley Online, Proquest u. c.

\subsection{Baiḷu un trauksmes rašanās mehānismi (patoğenēze)}

Viens no pirmajiem autoriem, kas sāka interesēties par bailēm un trauksmi, bija Z. Freids. Pētot un analizējot bailes un trauksmi, viņš secināja, ka tām ir divas izpausmes „reālistiskā trauksme” un „neirotiskā trauksme” (Freids, 2007). Z. Freids uzskatīja, ka reālistiskā trauksme ir visnotaļ racionāla un izpaužas kā „bēgšanas vai cīņas” uzvedība ārēja apdraudējuma vai stresa situācijās. Savukārt neirotisko trauksmi novēroja cilvēkiem, kuri pārdzīvoja ar dažādām vietām, situācijām vai objektiem nepiesaistītu trauksmi vai fobiskas reakcijas (Freids, 2007). Freids norādīja, ka fiziologiiskās reakcijas abu veidu trauksmes gadījumos ir līdzīgas, tomēr atšķirībā no reālistiskās trauksmes, kad apdraudējums ir reāls un atrodas ārējā pasaulē, neirotiskās trauksmes gadījumā apdraudējums ir iekšēji izjusts. Tātad indivīds izjūt trauksmi, reaǵējot uz šo iekšēji izjusto apdraudējumu.

K. Hornija precizēja Freida teoriju, izvirzīdama hipotēzi, ka bailes un trauksme ir divi atšķirīgi jēdzieni - bailēm ir ne tikai konkrēts cēlonis, bet tās izpaužas ar reakciju, kas ir proporcionāla baiļu iemeslam (Horney, 1999). Savukārt trauksme izpaužas kā briesmu iemeslam neatbilstoša, pārsp̄ilēta reakcija vai pat reakcija uz iedomātām bailēm. Autore arī piebilda, ka trauksmes, baiļu un fobiju gadījumā neizbēgami klātesošas ir nepārvaramas briesmas un neaizsargātība to priekšā. Viņa pieminēja arī to, ka intensīva trauksme ir viens no mokošākajiem afekta stāvokḷiem, kas saistās gan ar bezpalīdzību, gan ar zināmu iracionalitāti (Horney, 1999).

Spīlbergers secināja, ka dažiem cilvēkiem trauksme var būt situatīva, t. i., tā var izpausties kā reakcija uz konkrētu, apdraudošu situāciju (trauksme kā stāvoklis), savukārt citi cilvēki trauksmi piedzīvo nepārtraukti un trauksmaini reaǵē gan reālu, gan potenciālu draudu situācijās (trauksme kā personības iezīme) (Spielberger, 1966). Pēc autora domām, trauksme kā stāvoklis ir subjektīvi izjusts sasprindzinājums un nemiers kopā ar ierosinātu autonomo nervu sistēmu. Savukārt trauksme kā iezīme jeb vispārējā trauksme ir indivīda vispārēja predispozīcija, gatavība pieredzēt briesmas un apdraudējumu (Spielberger, 1966). Trauksme kā iezīme ir relatīvi stabila laikā (piemēram, veicot atkārtotu testēšanu), savukārt trauksme kā stāvoklis ir main̄̄ga laikā un ir atkarīga no dzīves situācijas (Zuckerman, 1979). Vispārējās trauksmes iespaids ir netiešs, tā kopā ar ārējiem faktoriem ietekmē (paaugstina) trauksmes 
stāvokli, kas, savukārt, iespaido cilvēka domāšanu un uzvedību (Eysenck, 1982). Tieši iezīmes jeb vispārējā trauksme iespaido paaugstinātu selektīvo uzmanību pret apdraudējumu vēstošiem stimuliem, tātad cilvēks nosacīti biežāk ir gatavs tam, ka kaut kas apdraudošs var notikt (Eysenck, 1982). Tādējādi trauksme kā iezīme jeb vispārējā trauksme liecina par cilvēka gatavību novērtēt situāciju attiecībā uz potenciālo apdraudējumu, savukārt trauksme kā stāvoklis raksturo visus konkrētajā brīdī izjustos draudošos stimulus un ir viena no daudzām adaptācijas reakcijām (kopā ar uzvedības un fiziologiiskajām reakcijām). Saistībā ar trauksmi parasti tiek pieminēta arī Lazarusa teorija par to, ka ar emociju palīdzību cilvēks pielāgojas videi, un katra no pamatemocijām ir saistīta ar konkrētu radniecīgu tēmu: trauksme - ar potenciālu apdraudējumu, skumjas - ar neatgūstamu zaudējumu utt. (Lazarus, 1991).

Frīmena pieskārās arī ǵimenes attiecību kvalitātei saistībā ar bailēm un trauksmi (Freeman, 2007). Autore atsaucās uz Annas Freidas koncepciju par somatiskas saslimšanas nozīmi bērna mentālajā dzīvē un atgādināja, ka bērniem, kuriem nepieciešama ārstēšana, pastiprinās separācijas trauksme (A. Freud, 1998; Freeman, 2007). Tādējādi bērnu iekšējā pasaule saskaras ar viņu vislielākajām bailēm - mātes zaudējuma varbūtību un nepieciešamību pasīvi pakḷauties ārstēšanai. Šādā stāvoklī bērna spēja tikt galā ar trauksmi ievērojami samazinās un bērna uzvedība regresē (A. Freud, 1998; Freeman, 2007). Frīmena interpretēja, ka šajā brīdī liela nozīme ir vecāku (mātes) uzvedībai un attieksmei - ja māte ir atbalstoša un spēj izturēt bērna bailes, bērns nomierinās un turpina funkcionēt atbilstoši vecumam; ja māte ir agresīva, bērns var izjust dusmas un reagéejot identificēties ar agresoru; ja māte ir satraukta, bērns var gan intensīvi pretoties ārstēšanai, gan, neraugoties uz bailēm, pasīvi tai pakḷauties (A. Freud, 1998; Freeman, 2007). Pēc autores domām, nozīme ir arī bērna uztveres īpatnībām - mazi bērni reti pārdzīvo reālas bailes, parasti viṇi pārvērtē savu fizisko spēku un var viegli iztēloties sevi pat ḷoti bīstamās situācijās. Tādējādi bērnu izjustās bailes un trauksme drīzāk attiecas uz neirotisko trauksmi, kuras izcelsme ir iekšējs apdraudējums. Iekšējais apdraudējums tiek saistīts ar bailēm zaudēt māti, bailēm no ievainojumiem un sāpēm, kā arī no bezpalīdzības, un šīs bailes sakņojas bērna uztverē un iztēlē (fantāzijās) par zobu ārstēšanu (Freeman, 2007).

Klasiskā nosacījuma refleksa teorija ir viena no pirmajām, ko piemin saistībā ar bailēm no zobārsta. Votsona eksperiments, kurš tika publicēts 1920. gadā, pierādīja to, ka bailes var iemācīties. Deviņus mēnešus vecam zēnam l̦āva spēelēties ar žurku, kas sākumā neizraisīja viņam nekādas emocijas. Tad katru reizi, kad bērns pieskārās žurkai, tika ieslēgts ļoti skaļš skaņas signāls, no kā bērns pārbijās un sāka raudāt. Eksperimenta turpinājumā bērns raudāja, tikai ieraugot žurku. Votsons pierādīja arī to, ka bailes var generalizēties, jo bērns vēlāk raudāja, arī ieraudzījis baltu trusi, pūkainu suni un pat masku ar bārdu no vates picin̄ām 
(Watson \& Rayner, 1920). Attiecinot šo teoriju uz medicīnu, pacients vispirms ierauga baltā halātā tērptu cilvēku, kurš veic sāpīgu procedūru (piemēram, injicē zāles), kas sekojoši izraisa pacientā beznosacījuma refleksu, proti, bailes, bērniem - arī raudāšanu. Savukārt, bērnam atkārtoti ieraugot cilvēku baltā halātā, viņš jau uzreiz to sasaista ar iepriekš izjustajām sāpēm. Viņam rodas bailes, kam pievienojas raudāšana kā nosacījuma reflekss (Watson \& Rayner, 1920; Armfield, 2006).

Bandura izvirzīja teoriju par sociālo iemācīšanos, kas notiek, bērnam vērojot un atdarinot apkārtējās vides cilvēku uzvedību un tās sekas (Bandura, 1971). Gan uzvedība, gan emocionālās atbildes var tikt iemācītas, novērojot citu cilvēku afektīvās reakcijas uz sāpīgu vai patīkamu pieredzi. Savukārt novērst baiḷpilno uzvedību var, netieši vērojot, kā citi iesaistās bailes izraisošās aktivitātēs bez jebkādām negatīvām sekām (Bandura, 1971). Šo iemācīšanos pastiprina informācija par sekām, kā arī domas par vispiemērotāko uzvedību (Bandura, 1971). Langs ierosināja ideju, ka bailes saistītas ar 3 komponentiem, kas var izpausties kā atsevišksi elementi vai pastāvēt kopā: subjektīvas izjūtas, izvairīšanās uzvedība un psihofizioloǵiski traucējumi (Lang, 1970). Pagājušā gadsimta septiņdesmitajos gados attīstījās arī Seligmana teorija par ,gatavību” bailēm, respektīvi, ne visi stimuli ir ekvipotenciāli, vienādi izraisa bailes. Vislielākās bailes izraisa tie stimuli, kas agrīnā cilvēces evolucionārās attīstības posmā rada dzīvības apdraudējumus (Seligman, 1971), piemēram, plēsoņas, dabas katastrofas vai pamestība. Tāpēc daudzās kultūrās pastāv līdzīga baiļu proporcija no augstuma, ūdens, dzīvniekiem, zibens/pērkona. Š̄is bailes ir „dabiskas”, pretstatā iemācītām (Leahy et al., 2006). Piemēram, ātra braukšana ar automašīnu mūsdienās var būt daudz bīstamāka par zirnekli, taču instinktīvā cilvēces pieredze nosaka, ka no zirnekḷa jābaidās, jo tas var būt indīgs un izraisīt nāvi (Kent \& Blinkhorn, 1991; Seligman, 1971). Vairākas desmitgades ļoti populāra bija Rahmana teorija par baiḷu patoǵenēzi. Saskaṇā ar to nosacījuma refleksam (jeb iepriekšējai negatīvai pieredzei) joprojām ir būtiska loma baiļu patoǵenēzē (Rachman, 1977). Tomēr autors norādīja, ka nosacījuma refleksa teorija pati par sevi neizskaidro to, ka dažas patiešām dramatiskas, dzīvību apdraudošas situācijas (piemēram, Londonas bombardēšana Otrā pasaules kara laikā) atstāja paliekošas bailes vai neirozes tikai atsevišķos cilvēkos, piemēram, mazos bērnos. Tāpat autors norādīja, ka reizēm bailes izraisa arī subtraumatiska vai atraumatiska pieredze (Rachman, 1977). Rahmans atsaucās uz Banduras sociālās iemācīšanās teoriju un secināja, ka baiļu izcelsmē svarīga ir arī vecāku attieksme un paskaidrojumi, kas ir būtiska audzināšanas sastāvdaļa (Rachman, 1977; Bandura, 1971). Tādējādi Rahmans pievienoja vēl divus baiļu patoǵenēzes izskaidrojumus netieša iemācīšanās (lomu modelis, pārņemts no vecākiem vai citiem nozīmīgiem cilvēkiem) un biedējošas informācijas sniegšana (Rachman, 1977). Savukārt Deivijs 1989. gadā izteica 
domu, ka baiļu veidošanās process ir atkarīgs no situācijas ilguma, sociāli un verbāli nodotās informācijas, kā arī iepriekšējiem priekšstatiem (angliski - pre-existing beliefs) (Davey, 1989). Savukārt baiḷu neesamību var izskaidrot ar diviem procesiem - latento inhibīciju (pacientam pirms traumējošās pieredzes ir bijušas vairākas atraumatiskas vizītes pie ārsta), kā arī baiļu stimula devalvāciju (ar apmeklējumu saistītā stresa noliegšana, selektīva ignorēšana vai nozīmīguma mazināšana) (Davey, 1989).

Armfīlds 2006. gada publikācijā uzdeva jautājumu, kāpēc ne visiem pacientiem, kam bijusi negatīva pieredze vai sāpes zobārsta apmeklējuma laikā, izveidojās bailes no zobārsta. Autors attīstīja kognitīvās ievainojamības teoriju, kas paredzēja, ka baiḷu rašanās atkarīga no 4 faktoriem: ārstēšanas procesa bīstamības, spējas to kontrolēt, tā neparedzamības un pretīguma (Armfield, 2006). Jo bīstamāks, apdraudošāks, pretīgāks, nekontrolējamāks un neparedzamāks cilvēkam šķita ārstēšanas process, jo ievainojamāks jutās pacients zobārsta kabinetā un lielākas bija viṇa bailes no zobārsta (Armfield, 2006).

Tomēr ne Rahmana, ne Ārmfīlda teorija neatbildēja uz jautājumu, kāpēc daži indivīìi ir ievainojamāki nekā citi, un Rahmans vienīgi pieminēja Eizenka ideju par neirotismu kā dalı no iedzimta temperamenta (Rachman, 1977; Eysenck, 1967). Savukārt Vassends ar līdzautoriem norādīja, ka pastāv trīs plašas etiologiskās hipotēzes - nosacījuma refleksa noteiktas atbildes uz nepatīkamu pieredzi pie zobārsta, predisponējošas temperamenta vai personības iezīmes, kā arī paaugstināts sāpju jutīgums un/vai bailes no sāpēm (Vassend et al., 2011).

Tātad trauksme saistīta ar cilvēka ārēju vai iekšēji izjustu apdraudējumu, uz kuru viņš reağē ar „cīṇas vai bēgšanas” reakciju jeb autonomās nervu sistēmas ierosinājumu, kas var būt un var nebūt proporcionāls faktiskajam apdraudējumam. Trauksme var būt kā pastāvīga personības iezīme, kas norāda uz gatavību jebkurā brīdī „cīnīties vai bēgt”, vai kā pārejošs stāvoklis, reakcija uz konkrētā brīd̄i izjustu apdraudējumu kopumu. Savukārt bailes saistītas ar nosacījuma refleksa izveidošanos pēc negatīvas pieredzes, iemācīšanos ar lomu model̦a un/vai negatīvas informācijas palīdzību, kā arī cilvēka subjektīvo ievainojamību temperamenta un personības īpatnību dēḷ.

\subsection{Iekšējie (endogēnie, indivīdu raksturojošie) faktori, kas ietekmē BTZ}

Ar bērnu BTZ saistāmi vairāki iekšējie faktori, kas, iespējams, to pastiprina. Tie saistīiti ar bērna vecumu, dzimumu, kā arī bērna temperamentu un vispārējo trauksmi, kā arī ar cita veida bailēm (Klingberg \& Broberg, 2007). Šie faktori ir svarīgi tāpēc, ka tie pārsvarā ir iedzimti vai pārmantoti un nemainās ārējās iedarbības rezultātā. Tajā pašā laikā šie faktori ir 
jāņem vērā zobārsta apmeklējuma laikā, jo ārsta taktika varēja radikāli atškşirties, strādājot ar 4 vai 12 gadus vecu bērnu, ar neirotisku vai kautrīgu bērnu. Turpinājumā sīkāk iztirzāsim šo faktoru saistību ar bailēm no zobārsta, kā arī BTZ saistību ar bērnu uzvedību.

\subsubsection{Bērnu vecums}

Kopumā bailes no zobārsta, tāpat kā vispārējās bailes, samazinājās, bērnam kḷūstot vecākam (Cuthbert \& Melamed, 1982; Klingberg et al., 1994; Milgrom et al., 1995; Raadal et al., 1995; Wogelius et al., 2003, Majstorovic \& Veerkamp, 2005). Bērna vecums un attīstības pakāpe apgriezti korelēja ar BTZ līmeni, jo mazi bērni grūtāk iejutās jaunā situācijā, izskaidrojums meklējams arī bērnu un pieaugušo lielumu atšķirībā (Kent \& Blinkhorn, 1991). Četrgadīgiem bērniem nereti vēl bija raksturīga separācijas trauksme pirmās zobārsta vizītes laikā, kas mazinās nākamo apmeklējumu laikā (Majstorovic \& Veerkamp, 2005). Bailes no konkrētiem stimuliem samazinājās, pieaugot bērna Ego spēkam un pašvērtējumam (Majstorovic \& Veerkamp, 2005). Samazinājās arī trauksme, jo mazinājās konstitucionālā ievainojamība no dažādiem trauksmi provocējošiem stimuliem (Majstorovic \& Veerkamp, 2005). Trauksme mazinājās līdz ar bērna intelekta pāreju konkrēto operāciju stadijā jaunākajā skolas vecumā (Folayan et al., 2004), kad bērnam pieauga kognitīvās spējas (Majstorovic \& Veerkamp, 2005) un parādījās vairāk kognitīvas baiḷu pārvarēšanas stratēgijas (Versloot et al., 2004). Tāpat jo vecāks bija bērns, jo vairāk reižu viņam bija iespēja gūt pozitīvu pieredzi pie zobārsta, lai neitralizētu agrīnākā vecumā gūtu negatīvu dentālo pieredzi (Lidell \& Locker, 1997).

Lai gan bailes no zobārsta samazinājās, bērnam pieaugot, tomēr šī samazināšanās sakarība ne vienmēr bija lineāra (Milgrom et al., 1995; Raadal et al., 1995; Akbay-Oba et al., 2009). Jau pirmais ar CFSS-DS veiktais pētījums parādīja, ka 5-14 gadus veciem bērniem vislielākās bailes no zobārsta bija nevis piecu, bet gan 6-7 gadu vecumā, un tās samazinājās tikai pēc š̄i vecuma (Cuthbert \& Melamed, 1982). Majstorovičas un Verkampa pētījumā 4-11 gadus veciem bērniem visaugstākais baiļu līmenis konstatēts četrgadīgajiem bērniem, turpmākā vecumā vidējā BTZ līkne virzìjās lejup, bet 11 gadu vecumā atkal būtiski kāpa (Majstorovic \& Veerkamp, 2005). Citos pētījumos konstatēts BTZ pieaugums 9-12 gadu, kā arī 15-18 gadu vecumā (Murray et al., 1989; Thompson et al., 2000), ko varētu izskaidrot ar individuālām personības iezīmēm vai pieredzēm pie zobārsta.

Tomēr vairākos pētījumos netika atrasta statistiski nozīmīga atšķirība baiļu no zobārsta līmenī starp jaunākiem un vecākiem bērniem (Alvesalo, 1993, Ten Berge, 2002, Nakai, 2005). 
Tātad lielākajā daḷā pētījumu bērnu baiḷu līmenis kopumā samazinājās līidz ar vecumu, saglabājoties atsevišķiem baiḷu pieauguma „kulminācijas punktiem” vēlākajos vecumu posmos.

\subsubsection{Bērnu dzimums}

Lielākajā daḷā pêtījumu meitenēm parādījās nedaudz lielākas bailes un trauksme saistībā ar zobārstniecību (Murray et al., 1989, Chellapah et al., 1990, Alvesalo et al., 1993, Raadal et al., 1995, Milgrom et al., 1995, Skaret et al., 1998; Versloot et al., 2004; Klingberg \& Broberg, 2007). Tikai vienā pētījumā varēja atrast, ka 9-11 gadus veciem zēniem bailes no zobārsta bija lielākas nekā meitenēm, un arī tad kopumā 4-11 gadus veco bērnu grupā nebija statistiski nozīmīgu atšķirību starp zēnu un meiteņu baiļu līmeni (Klingberg et al., 1994).

Tajā pašā laikā bija pietiekoši daudz pētījumu, kuros bailēm no zobārsta netika atrastas dzimumatšķirības jaunākā skolas vecuma bērniem (Milsom et al., 2003; Akbay-Oba et al., 2009; Beena, 2013). Taani un līdzautoru pētījumā par 12-15 gadus vecām pusaudžu meitenēm bija izteiktākas bailes no zobārsta nekā pusaudžu zēniem, bet atšksirība nebija statistiski nozīmīga (Taani et al., 2005).

Tātad pētîjumos bija pretrunīgi rezultāti par dzimuma saistîbu ar bailēm un trauksmi zobārstniecībā.

\subsubsection{Temperaments}

Temperaments ir apkopojošs termins personības iezīmju kopumam, kas izpaužas organizētā veidā jau agrīnā bērnībā, ir relatīvi stabils laikā un situācijās, ir daļēji pārmantojams un tam ir raksturīgs neirofiziologisks pamats (Arnrup et al., 2007). Temperaments ir dažādas, relatīvi stabilas organisma atbildes reakcijas uz vides kairinājumu, kas nosaka indivīda tipisko reakciju uz jaunu situāciju, tostarp, pirmo vizīti pie zobārsta (Gustafsson et al., 2010). Temperamentu reizēm saista ar reaktivitāti vai emociju regulāciju (Gustafsson et al., 2010). Tomass un Česa atzīmējuši tādas temperamenta dimensijas kā, piemēram, aktivitātes līmenis, regularitāte, reakcija uz jauno, pielāgošanās, sensorais jutīgums, reakcijas intensitāte, noskaņojums, uzmanības noturība un neatlaidība (Thomas \& Chess, 1977). Rotbarta ar līdzautoriem paplašināja raksturīgo temperamenta iezīmju sarakstu līdz 15 un apvienoja tās 3 lielās temperamenta dimensijās: ekstraversija (angliski extraversion/surgency), negatīva emocionalitāte (angliski - negative emocionality) un paškontrole (angliski - effortful control) (Rothbart et al., 2001). Savukārt Bass un Plomins 
izveidoja teoriju par EASI temperamenta iezīmēm (E - emocionalitāte, A - aktivitāte, S - sociabilitāte jeb sabiedriskums, I - impulsivitāte) (Buss \& Plomin, 1975). Vēlākās publikācijās par temperamentu pievienojās arī kautrīgums un emocionālā labilitāte (jeb negatīva emocionalitāte) (Vassend et al., 2011). Personības psiholoǵijā negatīvā emocionalitāte tiek saukta arī par neirotismu, un tā tiek saistīta ar daudziem internalizētiem psiholoǵiskiem traucējumiem, ieskaitot depresiju un trauksmi, kā arī ar eksternalizētām uzvedības problēmām (Vassend et al., 2011). Negatīvā emocionalitāte ir biežs, intensīvs un neproporcionāli liels negatīvo emociju pārdzīvojums un ekspresija (Vassend et al., 2011).

Kautrīgums jeb lēna ,iesildīšanās” dal̦ēji bija saistīts ar bailēm un kavēšanu (angliski inhibition), korelēja arī ar bailēm no zobārsta un uzvedības traucējumiem pie zobārsta (Gustafsson et al., 2007). Aktivitāte (kā temps un dzīvesspēks) un impulsivitāte (nosliece uz nepacietību un neatlaidības trūkums) arī varēja būt saistīiti ar uzvedības traucējumiem zobārsta kabinetā (Arnrup et al., 2007). Negatīva emocionalitāte (tendence ātri un intensīvi satraukties, it īpaši frustrācijas gadījumā), varēja ietekmēt bērna spēju sadarboties zobārsta kabinetā (Arnrup et al., 2007). Negatīva emocionalitāte bija saistīta ar bērnu uzvedības traucējumiem pie zobārsta visos gadījumos 8-12 gadu vecumā (Arnrup et al., 2007). Meitenēm nereti pievienojās kautrīgums un internalizētas psihopatologijijas, bet zēniem - impulsivitāte un eksternalizētas psihopatoloǵijas (Arnrup et al., 2007). Bērniem ar augstiem paškontroles (pašregulācijas pamatfaktors, kas monitorē un kontrolē domas un darbības) rādītājiem bija raksturīga pozitīva uzvedība zobārsta krēslā, kā arī autoritatīvs vecāku audzināšanas stils (Aminabadi et al., 2015). Bērniem ar augstu ekstraversijas (angliski - surgency/extraversion) jeb sabiedriskuma līmeni bija grūtības regulēt savu distresu, saskaroties ar vilšanos, kāa rezultātā viṇi trakoja zobārsta kabinetā. Negatīva emocionalitāte kā emociju disregulācijas rādītājs bija tieši saistīta ar liberālu (angliski - permissive) audzināšanas stilu, un šiem bērniem bija ievērojami augstāks baiļu no zobārsta un negatīvas uzvedības līmenis (Aminabadi et al., 2015). Autori piẹ̦āva, ka temperamentu ietekmēja bērnu - vecāku savstarpējā mijiedarbība. Vecāki varēja modulēt bērna temperamentu atkarībā no audzināšanas stila, attieksmes un prakses, bet tajā pašā laikā bērna temperaments varēja modulēt vecāku sniegto aprūpes veidu (Aminabadi et al., 2015).

Halonena un līdzautoru pētījumā par BTZ saistību ar personības iezīmēm vidēji 22 gadus veciem studentiem tika konstatēts, ka augsts neirotisms kā personības iezīme statistiski nozīmīgi pozitīvi korelēja ar ievērojamām bailēm no zobārsta, bet negatīva korelācija ar bailēm no zobārsta, kas nesasniedza statistisku nozīmību, bija arī zemai ekstraversijai (Halonen et al., 2012). Arī Lundgrēna un līdzautoru pētījumā tika konstatēta baiḷu no zobārsta statistiski nozīmīga pozitīva korelācija ar emocionalitāti, impulsivitāti un 
kautrīgumu, bet negatīva korelācija - ar sociabilitāti jeb sabiedriskumu pieaugušajiem (Lundgren et al., 2007).

Divdesmit deviņi procenti vecāku 6-12 gadus vecu bērnu grupā ar augstu baiļu līmeni apgalvoja, ka bailes no zobārsta varētu būt saistītas ar temperamenta faktoru, un vinuu bērni kopumā bija kautrīgi, bikli un bailīgi bez jebkāda specifiska iemesla vai traumatiska notikuma (Jafarzadeh et al., 2011). Iedzimtība noteica apmēram 33\% trauksmaino traucējumu, savukārt pārējā daḷa varētu būt apkārtējās vides noteikta (Fisak \& Grills-Taquechel, 2007).

\subsubsection{Vispārējā trauksme un cita veida bailes}

Bailes un trauksme zobārstniecībā bieži saistījās ar vispārējo trauksmi jeb trauksmi kā personības iezīmi. Singapūrā veiktā pētījumā 10-14 gadus veciem bērniem ar augstu „trauksmi kā stāvokli” gandrīz trīs reizes biežāk atzīmēja bailes no zobārsta, savukārt bērniem ar augstu „trauksmi kā iezīmi” baiḷu no zobārsta līmenis statistiski nozīmīgi neatšķīrās no pārējiem bērniem (Chellappah et al., 1990). Atsevišķas psiholoǵiskās iezīmes, piemēram, vispārējs bailīgums un trauksme kā iezīme, bija svarīgākas baiļu etioloǵijā nekā negatīva pieredze, ņemot vērā to, ka bailes no zobārsta varēja sākties arī pieaugušā vecumā (Locker et al., 1999). Citā pētījumā tika atrasta statistiski nozīmīga saistība starp bailēm no zobārsta un mazu (3-6 gadus vecu) bērnu trauksmi/satraukumu ikdienišķās stresa situācijās (Vogels et al., 2011). Torens ar līdzautoriem uzsvēra, ka bērniem ar trauksmi raksturīga specifiska kognitīva shēma, kas izcel negatīvo informāciju un izraisa negatīvu sevis un pasaules redzējumu. Trauksmainiem 6-14 gadus veciem bērniem bija zemākas lingvistiskās spējas un kognitīvā fleksibilitāte jeb elastība, kā arī vairāk kḷūdu un nepareizu atbilžu pēc negatīvas atgriezeniskās saites sniegšanas nekā kontrolgrupai bez trauksmes traucējumiem. Tomēr trauksme šajā pētījumā neietekmēja neverbālos procesus (Toren et al., 2000).

Bailes no zobārsta nereti korelēja ar citām bailēm. Berggrēns 1992. gadā pierādīja, ka pastāv statistiski nozīmīga korelācija starp bailēm no zobārsta un vispārējo trauksmi pieaugušajiem, un pusei no cilvēkiem ar spēcīgām bailēm no zobārsta piemīt bailes no vēl vismaz 5 objektiem (Berggren, 1992). Stenebranda ar līdzautoriem konstatēja, ka 63,3\% piecpadsmit gadus vecu pusaudžu bija vismaz vienas izteiktas bailes, bet vidējais baiļu skaits bija 2,8, turklāt bija statistiski nozīmīgas dzimumatšķirības: zēniem bija vidēji 1,2, bet meitenēm - 4,5 izteiktas bailes (Stenebrand et al., 2013). Visvairāk pusaudži baidījās no smakšanas, sāpēm, injekcijām, adatām un zirnekliem. Grupai ar bailēm no zobārsta bija statistiski nozīmīgi augstāks vispārējais baiļu līmenis nekā grupai bez bailēm no zobārsta (attiecīgi 3,9 un 2,3) un statistiski nozīmīgi lielāks baiḷu skaits (attiecīgi 9,9 un 2,3) 
(Stenebrand et al., 2013). Klingberga ar līdzautoriem konstatēja statistiski nozīmīgu saistību starp 4-11 gadu vecu bērnu vispārējām bailēm un bailēm no zobārsta, izmantojot CFSS-DS (bērnu baiļu pārskata zobārstniecības skala) un CFSS-SF (bērnu baiļu pārskata īsā forma, kurā minētas biežāk sastopamās bailes bērnu vecumā, piemēram, no asiem priekšmetiem, tumsas, svešiem/savādiem suņiem, zibens, palikšanas vienatnē) (Klingberg et al., 1994; Klingberg et al., 1995). Arī vispārējo baiḷu līmenis mazinājās, pieaugot bērnu vecumam, un neatškk̄īās zēniem un meitenēm (Klingberg et al., 1994). Folajans ar līdzautoriem konstatēja statistiski nozīmīgu saistību starp 8-13 gadu vecu bērnu bailēm no zobārsta un vispārējām bailēm (mērot ar CFSS-SF) (Folayan et al., 2004).

Baiļu struktūra mainījās, pieaugot bērna vecumam. Reflektorās bailes, piemēram, no tumsas vai pēkšņa trokšņa, saglabājas visu mūžu (Kuenkel, 2000). Pirmsskolas vecuma bērni reti pārdzīvo reālas bailes, drīzāk neirotisku trauksmi, kuras pamatā ir nevis ārējs, bet gan iekšējs apdraudējums (angliski - internal danger) - bailes zaudēt māti, bailes no ievainojumiem, sāpēm un bezpalīdzības (Freeman, 2007). Savukārt jaunākā skolas vecuma bērniem vairāk raksturīgas konkrētas bailes (no dzīvniekiem, sociālās bailes) (Kuenkel, 2000). Citā pētījumā konstatēts, ka 6-9 gadu vecumā raksturīgas bailes no šķiršanās (angliski separation anxiety), savukārt 10-13 gadu vecumā - bailes no nāves un briesmām (Weems \& Costa, 2005).

\subsubsection{Bērna uzvedības zobārsta kabinetā saistība ar bailēm no zobārsta}

Literatūrā bija pretrunīgi secinājumi par ārstēšanas pieredzes ietekmi uz bērna uzvedību pie zobārsta (Freeman, 2007).

Suprabas un līdzautoru pētījumā bērnu bailēm no zobārsta bija statistiski nozīmīga saistība ar 7-14 gadus vecu bērnu uzvedību zobārsta kabinetā (Suprabha et al., 2011). Klingberg et al. pētījums ar multiplo regresijas analīzi parādīja, ka $4-11$ gadus vecu bērnu uzvedības problēmas zobārstniecības kabinetā ir viens no faktoriem, kas saistās ar bailēm no zobārsta (Klingberg et al., 1995). Ja Venhems ar līdzautoriem apgalvoja, ka bērni ar katru ārstēšanas reizi aizvien labāk aklimatizējās un viņu uzvedība uzlabojās, tad Varpio un Velfelts atzīmēja, ka bērna uzvedība bija atkarīga no ārstēšanās pieredzes. Bērni ar mazu ārstēšanās pieredzi, saņēmuši nelielu palīdzību, viegli akceptēja zobu ārstēšanu, savukārt bērni ar lielāku iepriekšēju pieredzi mēdza kḷūt aizvien bailīgāki ar katru ārstēšanas reizi (Venham et al., 1980; Varpio \& Wellfelt, 1991; Freeman, 2007). Bērniem, kuru vecāki iepriekšējo pieredzi pie zobārsta atzīmēja kā negatīvu, tika biežāk novērota nekooperatīva uzvedība turpmākajos apmeklējumos (Pai et al., 2015). Arī vecāku attieksme (uztvere) pret zobārsta vizīti kā kaut 
ko nepatīkamu varēja tikt nodota bērnam un izraisīt negatīvāku uzvedību (Paryab \& Hosseinbor, 2013). Cits pētījums apstiprināja, ka tas, kā vecāki uztvēra bērna pirmo un arī turpmākās vizītes pie zobārsta (kā patīkamu vai nepatīkamu), ietekmēja 7-14 gadus vecu bērnu uzvedību pie zobārsta, bet ne bailes no zobārsta (Suprabha et al., 2011).

Savukārt Folajans ar līdzautoriem neatrada statistiski nozīmīgu saistību starp bailēm no zobārsta un 8-13 gadus vecu bērnu uzvedību pie zobārsta (Folayan et al., 2004).

\section{4. Ārējie, ar zobārstniecību saistītie faktori, kas ietekmē BTZ}

Literatūrā tika analizēti ārējie faktori, kas saistās ar BTZ. Daḷa ārējo faktoru bija saistīti ar pieredzi pie zobārsta vai citiem ārstiem. Sāpju dēḷ novēlota pirmā vai jebkura cita vizīte pie zobārsta varēja izraisīt BTZ. Negatīva un/vai traumatiska pieredze pie dažādiem ārstiem, it īpaši agrīnā vecumā, vēlāk varēja būt saistīta ar bailēm un trauksmi zobārstniecībā (Rantavuori et al., 2002). Arī fiziskas vai psiholoǵiskas traumas, kam bija nepieciešama neatliekama palīdzība, hroniskas saslimšanas, kas saistìjās ar biežu un sāpīgu ārsta apmeklējumu, var izraisīt BTZ. Ārstējošā personāla attieksme varēja būtiski ietekmēt bērna izjūtas pie zobārsta un attieksmi pret ārstēšanas procesu.

\subsubsection{Pirmā vizīte pie zobārsta}

Pirmā vizīte un tās norise var būt viens no kritiskajiem faktoriem bērna attieksmes pret zobārstu radīšanā. Jo agrākā vecumā mazulis bija bijis pirmajā vizịtē pie zobārsta, jo mazāk baiḷu no zobārsta vin̦š izjuta (Welly et al., 2011). Laba bērna uzvedība pirmās vizītes laikā pat vecumā, kas mazāks par 2 gadiem, norādīja uz mazākām bailēm no zobārsta un labāku sadarbošanos ar zobārstu vēlākajos gados (Lee et al., 2008). Savukārt problemātiska pirmā vizīte (kā bailes vai raudāšana) bija cieši saistīta ar bērnu bailēm no zobārsta (Rantavuori et al., 2002). Tomēr, ja bērnam pēc šīs vizītes bija sekojušas vēl vairāk nekā 3 vizītes, vēlams ar pozitīvu pieredzi, šī saistība ar BTZ vairs netika konstatēta (Rantavuori et al., 2002). Bērniem, kuri pirmajā zobārsta vizītē bija labi sadarbojušies (bijuši kooperatīvi), arī turpmākajās vizītēs bija statistiski nozīmīgi zemāki CFSS-DS rādītāji un klīniskā trauksme, kā arī labāka uzvedība zobārsta kabinetā (Lee et al., 2008). Arī ten Berge ar līdzautoriem apstiprina Deivija latentās inhibīcijas teoriju, ka, jo vairāk nesāpīgu apskates vizīšu bērnam bija bijis pirms ārstēšanas uzsākšanas, jo mazākas bija bērna bailes no zobārsta (Davey, 1989; ten Berge et al., 2002). Nepatīkama (sāpīga, biedējoša vai mulsinoša) pieredze (Suprabha et al., 2011) un invazīva, sāpīga zobu ārstěšana pirmās vizītes laikā bija saistīta ar vēlākām 
bērna bailēm no zobārsta (Lee et al., 2008). Bailēm no zobārsta bija lielākas izredzes attīstīties tad, ja traumatiskā pieredze bijusi pirmajā vizìtē pie zobārsta nevis vēlākajās vizītēs (Davey, 1989). Pat ja pirmā vizīte ir bijusi saistīta ar sāpēm, pēc iespējas ātrāk bija jāieplāno atkārtota pārbaudes vizīte, lai novērstu „,izvairīšanās uzvedības” rašanos (Rantavuori et al., 2002). Bērniem, kuriem bija bijušas vairāk nekā 10 vizītes pie zobārsta, bija statistiski nozīmīgi zemāki CFSS-DS rādītāji nekā bērniem ar mazāku vizīšu skaitu pie zobārsta (Lee et al., 2008). Bija pētījumi, kuros netika atrasta statistiski nozīmīga saistība starp bērna pieredzi pirmās vizītes laikā, bērna bailēm no zobārsta un bērna uzvedību zobārsta kabinetā (Paryab \& Hosseinbor, 2013).

Pēc Amerikas un Eiropas Bērnu Zobārstu asociāciju vadlīnijām bērna pirmajam apmeklējumam pie zobārsta jābūt līdz 1 gada vecumam (AAPD Guideline on Perinatal and Infant Oral Health Care, 2016; http://www.eapd.eu/804C40C2.en.aspx). Skandināvijā, bērna pirmā vizìte līdz 1 gada vecumam tiek koordinēta caur mātes un bērna veselības centriem, un to bieži veic apmācīti zobu higiēnisti (Poulsen, 2003). Savukārt sabiedriskajā zobārstniecības iestādē (Public Dental Service) bērnam jāatrādās līdz 2 gadu vecumam (http://www.folktandvardenstockholm.se/), un šīs vizītes tiek koordinētas ar uzaicinājuma vēstuļu palīdzību. Tādējādi liela nozīme tiek pievērsta tam, lai bērna pirmā vizīte pie zobārsta tiktu veikta tieši profilaktiskos nolūkos.

Kariess vai tā komplikācijas bija iemesls pirmajam zobārsta apmeklējumam ap 60\% bērnu Bulgārijā, 16\% pie zobārsta devās sāpju dēḷ, bet tikai 27\% gadījumu apmeklējums notika profilaktiskos nolūkos. Neliels zobārsta apmeklējumu skaits bija saistîts ar citiem iemesliem (piemēram, trauma, stomatīts, trūkstoši zobi u.tml.) (Mileva \& Kondeva, 2010). Arī ASV meksikāṇu izcelsmes amerikāṇu ǵimenēs ar zemiem ienākumiem bērna pirmā vizīte bija vidēji 3 gadu vecumā, apmēram pusē gadījumu - sāpju vai redzamu zobu problēmu dēl (Hoeft et al., 2011). Vēl kritiskāka situācija atklāta līdzīgos pētījumos Taivānā un Indijā. Tika konstatēts, ka kariess un/vai sāpes bija saistīts ar pirmo zobārsta apmeklējumu attiecīgi 79,6\% bērnu (Lee et al., 2008) un 55-77\% bērnu (Meera et al., 2008). Savukārt tikai zobu pārbaudes nolūkā pie zobārsta pirmoreiz ieradās tikai attiecīgi 7,7\% bērnu (Lee et al., 2008) un 1-5\% bērnu (Meera et al., 2008). Attiecīgi 62,7\% bērnu Taivānā jau pirmajā vizìtē tika veikta invazīva ārstēšana (t. i., plombēšana vai ekstrakcija) (Lee et al., 2008). Tādējādi BTZ profilaksei ir svarīgi, lai bērnam pirms zobu ārstēšanas uzsākšanas būtu bijis pietiekami daudz nesāpīgu vizīšu pie zobārsta. Tāpat ir svarīgi, lai pirmā bērna vizīte nebūtu saistīta ar sāpīgu, invazīvu ārstēšanu. Tomēr kariess un sāpes bija biežākais iemesls bērna pirmajai vizītei pie zobārsta dažādās pasaules valstīs, piemēram, Bulgārijā, Taivānā un Indijā. 


\subsection{2. Ārstēšanas uzsākšanas laiks}

Nesenā pētījumā Indijā netika atrasta statistiski nozīmīga saistība starp bērna vecumu pirmās vizītes laikā, bērna bailēm no zobārsta un bērna uzvedību zobārsta kabinetā (Paryab \& Hosseinbor, 2013). Citā pētījumā arī netika atrasta saistība starp 7-14 gadus vecu bērnu bailēm no zobārsta vai bērna negatīvo uzvedību un bērna vecumu pirmās zobārsta vizītes laikā (Suprabha et al., 2011). Bērniem, kas jaunāki par 4 gadiem, bija ievērojami lielākas bailes no zobārsta nekā 4 līdz 10 gadus vecajiem bērniem (Lee et al., 2008). Bērniem, kuru pirmā vizīte pie zobārsta bija pirms 2 gadu vecuma, bija augstāka klīniskā trauksme un sliktāka uzvedība zobārsta krēslā nekā bērniem, kuru pirmā vizīte bija 2-3 gadu vecumā vai 4 un vairāk gadu vecumā (Lee et al., 2008). Četri gadi varētu būt kritiskais vecums, līdz kuram lielākajai daḷai bērnu nav pietiekoši daudz kapacitātes, lai tiktu galā ar zobārstniecības situāciju (Lee et al., 2008). Pēc š̄i vecuma bērni psiholoǵiski strauji nobriest un daudz labāk tiek galā ar zobārstniecības situāciju (Lee et al., 2008). Šo viedokli apstiprināja pagājušā gadsimta pirmajā pusē veiktie Piažē fundamentālie, eksperimentālie pētījumi, kas parādīja, ka bērniem līdz apmēram 3 gadu vecumam raksturīgs t. s. „sensori motorais” intelekta attīstības periods. Tas nozīmē, ka šajā attīstības posmā ir raksturīga uztvere caur sajūtām un kustībām, kā arī neliels vārdu krājums, tāpēc bērns vēl neprot izteikt savu pieredzi vārdos (Piažē, 2002). Folajans ar līdzautoriem atsaucās uz Piažē secinājumiem, norādot, ka bērnam pirmsoperacionālās domāšanas perioda sākumā (2-4 gadu vecumā) uztveres ilūzijas visdrīzāk dominē pār logiisko pamatojumu (Folayan et al., 2004), un viņi ne vienmēr spēj aptvert, saprast un izskaidrot, kas ar viniiem notiek un kas ar viņiem tiek darīts. Tādējādi nesaprotamās darbības un notikumi tiek ,aizvietoti” ar ilūzijām (Freeman, 2007), piemēram, bērns līdz apmēram 4 gadu vecumam nespēj atšksirt spiediena sajūtu no sāpēm. Tomēr aptuveni 4 gadu vecumā bērna vārdu krājums strauji paplašinās un ir jau pietiekoši liels (Sternberg, 1996), līdz 5-6 gadu vecumam sasniedzot aptuveni 15000 vārdu (Klingberg et al., 2009), tāpēc runa pakāpeniski sāk atgādināt pieauguša cilvēka teikuma uzbūvi un valodas struktūru. Tādēḷ, sākot no šī vecuma, bērnam arvien saprotamāki ir viņam adresētie pieaugušā vārdi (lai gan tiem joprojām jābūt bērnam saprotamā līmen̄̄) (Sternberg, 1996). Bērns zobārsta vizītes laikā pārsvarā ir informācijas uztvērējs, bet zobārsts - devējs, tādējādi vienas zobārstniecības sesijas laikā zobārsts vidēji pasaka ap 200 vārdiem, savukārt bērns - ap 10-15 vārdiem (Caglar et al., 2015).

Literatūrā ir pretrunīgi rezultāti par agrīnas zobu ārstēšanas uzsākšanas laika saistību ar bailēm no zobārsta. Tomēr ir lielāka iespēja, ka bērni, kas uzsākuši zobu ārstēšanu 4 gadu 
vecumā un agrāk, baidīsies no zobārsta vecuma un uztveres īpatnību, kā arī ierobežotā vārdu krājuma dēḷ.

\subsubsection{Negatīva (traumatiska) pieredze pie zobārsta}

Jebkura sāpīga, biedējoša vai apkaunojoša pieredze pie zobārsta var tikt definēta kā negatīva pieredze pie zobārsta (Suprabha et al., 2011). Tomēr pārsvarā negatīva pieredze saistās ar sāpēm vai nepatīkamu zobārsta attieksmi.

Frīmena apgalvoja, ka, ja sāpes vai nepatīkamas izjūtas nebija saistītas ar bailēm būt ievainotam, sodītam vai vajātam, tās tika viegli aizmirstas. Trauksmainiem bērniem ar dzīvu iztēli sāpes vai diskomforts viegli palika atmiņā (Freeman, 2007). Ja bērns vienreiz bija izjutis sāpes, tas veicināja paliekošu baiļu no zobārstniecības izveidošanos (Harman et al., 2005). Atmiṇā saglabātais sāpju līmenis ievērojami nozīmīgāk korelēja ar iedomāto jeb sagaidāmo sāpju līmeni nekā ar piedzīvotajām sāpēm, it īpaši respondentiem ar izteiktām bailēm no zobārsta (Kent, 1985). Jo nepatīkamāka un/vai sāpīgāka bija ārstēšana, jo lielāka bija iespēja, ka trauksmainiem un/vai agresīviem bērniem aktuālā pieredze saslēgsies ar viņu fantāzijām par bezpalīdzību, ievainojamību un sodu, kā arī ar iekšēja apdraudējuma izjūtu. Kopā ar mātes trauksmainu uzvedību tas noveda pie regresijas un bērna faktiskajam vecumam neatbilstošas uzvedības un nespējas tikt galā ar bailēm (Freeman, 2007).

Vecāki, kuriem pašiem bērnībā bija bijusi negatīva pieredze pie zobārsta, vēēāk to „atcerējās vārdos un atkārtoja darbos”, respektīvi, maksimāli atlika arī savu bērnu zobu ārstēšanu, līdz bija iespējama vairs tikai sāpošā zoba ekstrakcija (Smith \& Freeman, 2010). Tieši šāds uzvedības modelis izraisīja bērnā bailes no zobārsta un attīstīja uzvedības modeli, kad ārstēšana tiek atlikta līdz pēdējam brīdim (,,apburtā loka” fenomens) (Smith \& Freeman, 2010).

Jo vairāk pirms faktiskās zobu ārstēšanas bērniem bija bijušas pārbaudes vizītes, jo mazākas bija viṇu bailes no zobārsta (Davey, 1989). Jo invaz̄ivāka un ilgāka bija ārstēšana, jo sliktāka bija bērna uzvedība zobārsta krēslā, neskatoties uz pakāpenisko ārstēšanu/desensitizāciju (Pai et al., 2015). Bailes no zobu ārstēšanas dažādās bērnu vecuma grupās bija vairāk raksturīgas respondentiem, kas bija piedzīvojuši ārstēšanas procedūras nekā tiem, kam zobi nebija ārstēti (Klingberg et al., 1994; Rantavuori et al., 2009). Bērniem (4-6 un 9-11 gadu vecumā), kam iepriekš veikta plombēšana bez vietējās anestēzijas, bija vairāk raksturīgi uzvedības traucējumi saistībā ar zobārstniecības situāciju nekā bērniem, kam zobi laboti ar anestēziju (Klingberg et al., 1994). Augstāks baiļu no zobārsta līmenis bija tiem 11 gadus veciem bērniem, kas pie zobārsta bija bieži izjutuši sāpes, nekā tiem, kas sāpes 
izjuta reizēm vai neizjuta nekad (Versloot et al., 2004). Iepriekš veiktas ekstrakcijas piecgadīgiem bērniem 3,5 reizes palielināja varbūtību, ka bērns baidīsies no zobārsta, atšķirīibā no iepriekš veiktas plombēšanas (Milsom et al., 2003). Deviņgadīgiem bērniem, kuriem bija veikta zobu ekstrakcijas (ar zobu plombēšanu vai bez tās), bija lielākas bailes no zobārsta nekā bērniem ar intaktu sakodienu vai bērniem, kuriem tika veikta tikai zobu plombēšana (Karjalainen et al., 2003).

Bērniem, kuru vecāki atzīmēja iepriekšējo pieredzi pie zobārsta kā negatīvu, tika biežāk novērota nekooperatīva uzvedība turpmākajos apmeklējumos (Pai et al., 2015). Arī vecāku attieksme (uztvere) pret zobārsta vizīti kā kaut ko nepatīkamu varēja tikt nodota bērnam un radīt negatīvāku uzvedību (Paryab \& Hosseinbor, 2013). Tas, kā vecāki uztvēra bērna pirmo un arī turpmākās vizītes pie zobārsta (kā patīkamu vai nepatīkamu), ietekmēja 7-14 gadus vecu bērnu uzvedību pie zobārsta, bet ne bailes no zobārsta (Suprabha et al., 2011). Bērniem, kuriem zobi bija sāpējuši vienu vai vairākas reizes, bija gandrīz 3 reizes augstāka baiļu no zobārsta izplatība $(O R=2,93)$ (Wogelius et al., 2003). Bērniem, kuriem bijušas neizturamas sāpes pirmajā vai kādā citā ārstēšanas reizēe bija statistiski nozīmīgi augstāki CFSS-DS rādītāji nekā bērniem, kuriem nebija bijusi sāpīga ārstēšana (Lee et al., 2008). Tomēr neizturamas sāpes zobu ārstēšanas laikā bija subjektīvs rādītājs, ko ietekmēja bailes no zobārsta (Lee et al., 2008). Iepriekšējo vizīšu emocionālā kvalitāte bija nozīmīgāka nekā vizīšu skaits (Suprabha et al., 2011).

Tātad negatīva pieredze pie zobārsta, it īpaši subjektīvi izjustas sāpes, pārsvarā tika pieminēts kā viens no iemesliem bailēm no zobārsta. Ekstrakcijas vai cita invazīva vai ilga zobu ārstēšana palielināja iespēju, ka izveidosies BTZ, it īpaši maziem bērniem, kuriem iepriekš nebija bijusi cita, pozitīva pieredze pie zobārsta.

\subsection{4. Ārstniecības personāla attieksme}

Bērniem, kuri regulāri apmeklēja vienu noteiktu klīniku, bija statistiski nozīmīgi zemāki CFSS-DS rādītāji nekā bērniem, kas apmeklēja dažādas klīnikas (Lee et al., 2008), savukārt bērniem, kuri regulāri apmeklēja vienu noteiktu zobārstu, bija statistiski nozīmīgi zemāka klīniskā trauksme zobārsta kabinetā (Lee et al., 2008). Tātad zobu ārstēšana pazīstamā vidē varēja samazināt bērna bailes no nezināmā, kā arī bailes no svešiniekiem, un veicināt uzticēšanos un drošības izjūtu (Lee et al., 2008).

Pacienta - zobārsta mijiedarbība ir saistîta ar pacienta droš̄ibas un kontroles izjūtu, tāpat arī ar izvairīšanās uzvedību (Armfield et al., 2008; Carrillo-Diaz et al., 2012). Spēcīgas bailes ietekmēja (sašaurināja) pacienta kognitīvos procesus: uzmanību, atmiṇu un domāšanu 
(Öhman et al., 2001; Fredrickson \& Branigan, 2005). Tāpēc nesaprašanās komunikācijas laikā varēja radīt neuzticēšanos, pesimistiskas gaidas, kā arī nereālistiskas, negatīvas vai katastrofiskas domas (Carrillo-Diaz et al., 2012). Tāpēc pacienti ar izteiktām bailēm no zobārsta bija kognitīvi ievainojamāki un jūtīgāki pret zobārstniecības personāla verbālo un neverbālo komunikāciju (Jaakkola et al., 2014). Bailes no zobārsta ietekmēja to, kā pusaudži uztver saskarsmi ar zobārstniecības personālu: pacienti ar lielākām bailēm no zobārsta biežāk nekā vienaudži uztvēra zobārstniecības personālu kā rupju un jutās nedrošāki (Jaakkola et al., 2014). Savukārt empātiskai attieksmei un sapratnei, jūtīgumam pret pacienta emocionālajām reakcijām un vajadzībām, konstruktīvām komunikācijas spējām, uzmanīgumam, atbalstam un nenosodīšanai bija noteicoša loma darbā ar bailīgiem pacientiem (Jaakkola et al., 2014). Zobārsta empātiska komunikācija, kurā uzman̄̄bas centrā bija bērna jūtas un ārsta taktiska uzvedība apvienojumā ar skaidriem un specifiskiem norādījumiem, mazināja bērna trauksmi un uzlaboja viņa noskaņojumu (Sarnat et al., 2001). Tāpat bērna uzvedību zobārsta krēslā uzlaboja sensorās informācijas sniegšana un iemeslu paskaidrošana, jautāšana par izjūtām, kā arī pārliecināšana (Weinstein et al., 1982; Sarnat et al., 2001; Zhou et al., 2011). Verbālai komunikācijai varēja būt pozitīva vai negatīva ietekme uz bērna uzvedību atkarībā no pielietotās baiļu pārvarēšanas stratēgijas. Komunikācija palielināja bailes no zobārsta, ja bērns lietoja uzmanības novēršanas taktiku, savukārt, ja bērns vēēēās informāciju, lai mazinātu bailes no gaidāmā, nezināmā, komunikācija samazināja bailes no zobārsta (Buchanan \& Niven, 2003; Folayan et al., 2004). Zobārsta laba paškontrole un pārliecība par sevi, skaļa un droša balss, pietiekoši labs savstarpējais kontakts ar pacientu un uzmundrinošs pieskāriens apvienojumā ar vārdiskiem paskaidrojumiem un apliecinājumiem samazināja bērna bailīgu uzvedību (Zhou et al., 2011).

Savukārt bērna sodīšana jeb vārdos izteikta kritika par nesadarbošanos ievērojami palielināja bērna bailes (Zhou et al., 2011; Melamed et al., 1983). Tāpat bērna uzvedību neuzlaboja pierunāšana, piespiešana, pazemošana, ārstēšanas pārtraukšana, kā arī turēšana un fiziska ierobežošana (Zhou et al., 2011). Salīdzinot 8-13 gadus vecu bērnu baiḷu no zobārsta līmeni pirms ārstēšanas un pēc tās, bailes vairāk samazinājās pacientiem, kurus ārstēja profesionāli vairāk pieredzējuši zobārsti. Autori izskaidroja rezultātus ar to, ka, iespējams, zobārsti ar lielāku darba pieredzi kombinē vairākas uzvedības pārvaldības metodes (Folayan et al., 2004).

Sensori adaptēta zobārstniecības vide (ar dažādu krāsu gaismām, ritmisku mūziku un taktiliem stimuliem) ievērojami samazināja 6-11 gadu vecu bērnu bailes no zobārsta un uzlaboja viņu uzvedību zobu higiēnas laikā (Shapiro et al., 2007). 
Tātad - ārstēšanās pazīstamā un pozitīvā vidē ar empātisku un iejūtīgu zobārstniecības personālu bija saistīta ar mazākām bailēm no zobārsta. Savukārt ārstniecības personāla izteikta pacienta kritizēšana, piespiešana, pazemošana un turēšana palielināja jaunās paaudzes bailes no zobārsta. Tomēr jāṇem vērā, ka bērni un pusaudži ar BTZ ir jūtīgāki pret zobārstniecības personāla uzvedību un attieksmi un biežāk uztver to kā rupju vai neuzmanīgu.

\section{5. Ārējie, ar ğimeni saistītie faktori}

Bērnu bailes un trauksme zobārstniecībā var būt saistîta arī ar tādiem ārējiem faktoriem kā vecāku bailes un trauksme zobārstniecībā, kā arī vecāku sociālekonomiskie un sociāldemogrāfiskie rādītāji (Rantavuori et al., 2009). Vecāku attieksmei pret zobārstu bieži vien ir saistība ar bērnu bailēm no zobārsta kaut vai tādēḷ, ka viņi nespēj bērnam paskaidrot zobārsta kabinetā notiekošo, izstrāvo trauksmi vai nodod konkrētu uzvedības modeli (Rachman, 1977). Zems sociālekonomiskais stāvoklis var atturēt vecākus no bērna vešanas pie zobārsta, tādēl retu vizīšu dēl bailes no zobārsta var pastiprināties. Tādējādi vecāku attieksmei ir liela nozīme bērnu BTZ etioloğijā.

\subsubsection{Mātes un/vai tēva bailes no zobārsta}

Pētījumi pierādīja, ka vecāku trauksmes līmenis mēreni korelēja ar viņu bērnu trauksmi (Frick et al., 1995; Krain \& Kendall, 2001; Costa \& Weems, 2005). Tāpat pētījumi pierādīja, ka trauksme bieži bija saistīta ar ğimeni (Dadds \& Barret, 1996; Costa \& Weems, 2005). Trauksmainie traucējumi tika pārmantoti aptuveni 30 - 40\% gadījumu (Hettema et al., 2001; Costa \& Weems, 2005). Citos pētījumos apstiprinājās, ka genētiskie faktori izskaidroja apmēram vienu trešdaļu trauksmaino traucējumu (Eley, 2001; Fisak \& Grills- Taquechel, 2007). Šì saistība pastāvēja arī attiecībā uz bailēm un trauksmi zobārstniecīiā. Pirms vairākiem gadiem veiktā metaanalīzē par bērnu un vecāku bailēm no zobārsta tika konstatēta pārliecinoša un statistiski nozīmīga savstarpējā korelācija (71-79\% pētījumos), ja bērni bija vecumā līdz 8 gadiem (Themessl-Huber et al., 2010). Savukārt, ja bērni bija vecāki par 8 gadiem, pētījumiem bija pretrunīgi rezultāti - vairs tikai apmēram 50\% apstiprināja saistību starp bērnu un vecāku bailēm no zobārsta (Themessl-Huber et al., 2010).

Milsoms ar līdzautoriem piecgadīgu bērnu šksērsgriezuma pētījumā secināja, ka bailīgiem bērniem 1,6 reizes biežāk vecāki arī baidījās no zobārsta (Milsom et al., 2003). Mātes bailēm no zobārsta bija statistiski nozīmīga saistība ar augstiem CFSS-DS rādītājiem, klīnisko trauksmi un nekooperatīvu uzvedību zobārsta kabinetā (Lee et al., 2008). 
Mātes bailes no zobārsta, nesadarbošanās pirmās vizītes laikā, vecums līdz 4 gadiem, spēcīgas sāpes pirmās vizītes laikā un dažādu zobārstniecības klīniku apmeklējums bija faktori, kas saistīti ar augstiem CFSS-DS rādītājiem un izskaidroja 36,2\% no CFSS-DS rādītāju variācijas (Lee et al., 2008). Augsti CFSS-DS rādītāji, vecums līdz 4 gadiem, pirmais bērns gimenē, dažādu zobārstu apmeklējums un nesadarbošanās pirmās vizītes laikā bija faktori, kas saistīti ar klīnisko trauksmi zobārsta kabinetā un izskaidroja 40,2\% no tās variācijas (Lee et al., 2008). Klīniskā trauksme bija vienīgais faktors, kas bija saistīts ar bērna nekooperatīvo uzvedību zobārsta kabinetā un izskaidroja 85,4\% uzvedības variācijas (Lee et al., 2008). Rantavuori ar līdzautoriem 2009. gadā konstatēja, ka bērniem dažādās vecuma grupās (no 6 līdz 15 gadiem) bija saistība ar mātes, tēva un/vai brāḷu un māsu bailēm no zobārsta, respektīvi, bija nozīme netiešai iemācīšanai jeb nosacījuma refleksa izveidei (Rantavuori et al., 2009).

Džafardazeas un līdzautoru pētījumā vecāki bērniem ar augstu baiḷu no zobārsta līmeni biežāk domāja, ka bērnu bailēm no zobārsta ir ārējs cēlonis (negatīva pieredze pie zobārsta, zobu problēmas, zobārsta uzvedība), savukārt bērniem ar zemu baiļu līmeni vecāki bailes no zobārsta vairāk izskaidroja ar saviem iepriekš sniegtajiem paskaidrojumiem (angliski - parental guidance) (Jafardazeh et al., 2011). Jautāti par preventīviem faktoriem bērnu bailēm no zobārsta, bērnu, kam bija augsts baiḷu no zobārsta līmenis, vecāki pārsvarā norādīja uz faktoriem, kas saistīti ar zobārstu, savukārt grupā ar zemu baiḷu līmeni - uz izglītošanu un iedrošināšanu. Tādējādi bērnu ar zemu baiļu līmeni vecāki vairāk juta spēju pašiem kontrolēt bērna bailes no zobārsta, bet bērnu ar augstu baiļu līmeni vecāki neuzskatīja par iespējamu novērst un kontrolēt bērna bailes no zobārsta (Jafardazeh et al., 2011).

Bērnu un vecāku savstarpējās mijiedarbības efektivitāte bija svarīgs rādītājs tam, kā bērns reaǵēs sarežğītās situācijās, tāpēc vecāku uzvedība tika pētīta kā iespējamais trauksmes pārneses mehānisms (Aminabadi et al., 2015). Autori arī atsaucās uz citu pētījumu par to, ka trauksmainu bērnu vecāki izturējās pret bērniem vienlaikus kontrolējoši, noraidoši un pārāk aizbildnieciski (angliski - overprotecting) (Aminabadi et al., 2015; Rapee, 1997). Aminabadi un līdzautoru pētîjumā autoritatīvu vecāku bērniem bija statistiski nozīmīgi zemāks baiḷu līmenis un labāka uzvedība zobārsta krēslā, savukārt autoritatīvu un liberālu (angliski permissive) vecāku bērniem bija daudz augstāks baiļu līmenis un uzvedības problēmas (Aminabadi et al., 2015).

Saskaṇā ar Banduras sociālās iemācīšanās teoriju un Rahmana teoriju par bailēm no zobārsta viens no veidiem, kā bērni ieguva trauksmainu uzvedību, bija lomu modeḷa pārṇemšana no vecākiem (Bandura, 1971; Rachman, 1977). Vecākiem, kuri bieži vai vienmēr izrādīja savu trauksmi vai bailes, arī bērniem bija augstāki baiḷu/trauksmes rādītāji (Muris 
et al., 1996; Fisak \& Grills-Taquechel, 2007). Tāpat bērniem ar vairākiem trauksmes simptomiem raksturīgs tas, ka vecākiem bija trauksmaināks audzināšanas stils (Fisak \& Grills-Taquechel, 2007).

Saistībā ar baiḷu no zobārsta psihoanalītisko teoriju raksturoja trīs mātes-bērna diādes veidus: kompetenta, agresīva un trauksmaina (Hummel, 2001; Freeman, 2007). Ja kompetentā diādē māte pastāvīgi un konsekventi kontrolēja bērna uzvedību, saprata un atbalstīja viņa emocionālās vajadzības, kā arī veicināja bērna sociālās iemaņas un neatkarību sociālā situācijāa (tostarp zobārstniecībā), tad agresīvas un trauksmainas diādes gadījumā bija raksturīgi sarežǵḡjumi. Neuzticēšanās, ko bērns pārdzīvoja, kopā ar mātes ambivalenci izraisīja vāju savstarpējo komunikāciju un emocionālu norobežošanos starp bērnu un māti. Trauksmainas un/vai agresīvas mātes, kas bija emocionāli distancētas, nedzirdēja sava bērna vārdus un nespēja tos sasaistīt ar bērna emocijām. Turpretī bērni "bombardēja” vecākus ar sarežğìtu un/vai kaitinošu uzvedību, lai iegūtu vecāku uzmanību un mīlestību. Vecāki atbildēja ar vēl stiprāku kontroli, kas izraisīja vēl vājāku sadarbību ar bērnu un graujošāku uzvedību. Tādējādi vecāki nevis apvaldīja bērnu un viņa iekšējo apdraudējuma sajūtu, bet ar savām asajām atbildēm, hiperkontroli, dusmām un pat naidīgumu to vēl vairāk pastiprināja. Trauksmainu un agresīvu māšu trauksmainie bērni uztvēra zobārstniecības situāciju kā bīstamu (draudu un sodu) un rezultātā izvairījās no zobu ārstēšanas (Freeman, 2007).

Verslota ar līdzautoriem uzskatīja, ka bērna spēja tikt galā ar zobu ārstēšanu bija atkarīga ne tikai no bērna psihologiskā un kognitīvā brieduma, bet arī no vecāku baiḷu neesamības (angliski - absence) (Versloot et al., 2004). Vecāku reakciju konsekvence un paredzamība bija ļoti nozīmīga brīžos, kad bērnam bija jātiek galā ar savām bailēm un trauksmi. Ja gimene bija funkcionāla un vecāki spēja veidot pozitīvu, konsekventu un audzinošu sadarbību ar bērniem, tad zobārstniecības situācijā viṇi spēja apvaldīt savas bailes un adekvāti tikt galā ar savu trauksmi (Freeman, 2007; Hamburg \& Hamburg, 2004). Smita un Frīmena 2010. gadā kvalitatīvā pētījumā konstatēja, ka vecāki, kuriem bērnībā bijusi negatīva pieredze pie zobārsta, vēlāk to ,atceras vārdos un atkārto darbos”, proti, piedzīvotais bērnībā lika izvairīties no rutīnas zobu ārstēšanas arī vēlāk pieaugušā vecumā un atlikt, cik iespējams, arī zobu ārstēšanu saviem bērniem, līdz vairs bija iespējama tikai sāpošā zoba ekstrakcija. Pētījumā arī konstatēts, ka pārsvarā šādi vecāki sāpošus un bojātus zobus uztvēra kā kaut ko fatālu, neizbēgamu un „ǵenētiski pārmantotu”, un neuzskatīja sevi par rutīnas ārstēšanas kandidātiem un profilaktiskās pārbaudes par iespējamām (Smith \& Freeman, 2010).

Tomēr Folajans ar kolēgiem 2002. gada pētījumā neatrada saistību starp mātes un bērna vai tēva un bērna bailēm no zobārsta, lai gan literatūrā atsaucās uz vairākiem 
pētījumiem, kuros bija pierādīta saistība starp mātes un bērna bailēm no zobārsta (Folayan et al., 2002). Autors skaidroja rezultātus ar afrikāņu kultūras īpatnībām, kurā vecākiem nav pieņemts dalīties un izrādīt emocijas bērniem, it īpaši bailes, satraukumu vai sāpes. Arī Taivānas pētījumā minēts, ka gimenes locekḷiem nav pieņemts pārrunāt savas bailes (no zobārsta) bērnu klātbūtnē, tomēr mātes bailes no zobārsta statistiski nozīmīgi korelēja ar bērna bailēm (Lee et al., 2008).

Kopumā bērnu bailes no zobārsta un uzvedību pie zobārsta lielā mērā ietekmēja gan vecāku pieredze pie zobārsta un BTZ, gan audzināšanas stils un savstarpējā sadarbība, kā arī atbalsts, ko zobārsta apmeklējuma laikā sniedza pavadošā persona.

\subsubsection{Vecāku sniegtā sagatavojošā informācija}

Rahmana teorija paredzēja trīs bērnu baiļu veidošanās veidus: nosacījuma refleksa veidošanās caur traumatisku pieredzi pie zobārsta, aizstājošā pieredze (iemācītās bailes jeb modelēšana) un draudīga, bailes izraisoša informācija (Rachman, 1977). Chadwick un Hosey minēja, ka vecāki zobārsta kabinetā nereti "aplipina" bērnus ar trauksmi, pārnesdami uz bērnu savas izjūtas (,Tu tikai neuztraucies”), tāpat veic labi domātu, bet neatbilstošu sagatavošanu („Tev nekas nesāpēs”, „Tev neko nedarīs"), bērnam dzirdot, diskutē par zobārstniecības negatīvajām lietām, kā arī atklāti baida bērnu ar zobu ārstēšanu vai pat ekstrakciju (Chadwick \& Hosey, 2003).

Tomēr pastāvēja pretrun̄̄gi rezultāti pētījumos par sagatavojošu informāciju pirms zobārstniecības procedūrām. Fokss un N̦ūtons pētījumā konstatēja statistiski nozīmīgas atšķ̧irības bailēs no zobārsta 5 līdz 17 gadus veciem bērniem atkarībā no tā, vai pirms vizītes bērni redzēja attēlu ar lācīti zobārsta krēslā vai attēlu ar aug̣̦iem (Fox \& Newton, 2006). Arī citi pētījumi apliecināja, ka pirms dažādām citām nepatīkamām procedūrām, tostarp zobu ārstēšanas, ekstrakcijas, medicīniskām manipulācijām vai ausu caurduršanas, sniegtā sagatavojošā informācija samazināja bailes no šīs procedūras (Inzana et al., 1996, $N g$ et al., 2004, Spafford et al., 2002). Savukārt sekojošā pētījumā Olumide ar līdzautoriem 2009. gadā neatrada statistiski nozīmīgas atšķirības bailēm no zobārsta 8-12 gadus bērniem, kas pirms zobārsta apmeklējuma saņēma informējošus bukletus par zobārsta vizītes norisi vai bukletus par veselīgu pārtiku (Olumide et al., 2009). Folajans un Idehens 2004. gada pētījumā neatrada statistiski nozīmīgas atšksirības 8-13 gadus vecu bērnu bailēm no zobārsta atkarībā no informācijas tipa, kāda tika saņemta pirms zobārsta apmeklējuma (Folayan \& Idehen, 2004). Autori atsaucās uz citu pētîjumu, ka, no vienas puses, pastāvēja saistība starp informācijas trūkumu un izteiktu trauksmi, no otras puses, tiem, kuri bija informēti, trauksme vienalga 
saglabājās (Flury et al., 2001; Folayan \& Idehen, 2004), turklāt nozīme bija arī veidam, kādā informācija tika pasniegta. Folajana un Idehena pētījumā sagatavojošā informācija, ko bija sniegušas mātes, tēvi vai citi ǵimenes locekḷi, bija ḷoti nespecifiska, piemēram, frāze „zobu ārstēšana nesāpēs” tika uzskatīta par pozitīvu sagatavojošu informāciju, savukārt frāze „,zobu ārstēšana ir sāpīga" - par negatīvu (Folayan \& Idehen, 2004). Lai mazinātu trauksmi pirms ārstēšanas, informācijai bija jābūt specifiskākai, nedaudz detalizētākai, jo īpaši attiecībā uz sāpju kontroli (Auerbach et al., 1983; Jackson \& Lindsay, 1995; Flury et al., 2001; Folayan \& Idehen, 2004).

Balstoties uz Rahmana teoriju, informācijas pārnese ir viens no trim mehānismiem bez modelēšanas (bērns skatās un atkārto, atspoguḷo vecāku bailes) un bail̦pilnas uzvedības pastiprināšanas (izvairīšanās no bailīgās situācijas vai kairinātāja), kādā vecāki nodod savas bailes un trauksmi bērniem (Rachman, 1977). Tas, vai bērnā bailes radīsies vai nē, atkarīgs no pozitīvas vai negatīvas ievirzes neitrāli sniegtā informācijā. F̄̄lda un Losona pētījumos veids, kādā vecāki komunicēja ar bērnu, iespaidoja to, kā 7-9 gadus vecie bērni interpretēja dažādas situācijas vai stimulus. Informācijas tips (pozitīva vai negatīva) iespaidoja pētījumā uzdotā uzdevuma izpildes laiku, kas l̦āva pieņemt, ka negatīvā informācija ietekmē bērna automātisko kognitīvo negatīvā stimula apstrādi, saskaroties ar to. Citiem vārdiem sakot, bailes un trauksme kavēja izpildīt uzdevumu ar objektu, par kuru iepriekš bija saņemta negatīva informācija (Field \& Lawson, 2003). Tāpat baiļu izcelsmē liela nozīme bija tam, cik lielu nozīmi informācijas saņēmējs piešķīra informantam, piemēram, mammas vai skolotāja teiktajam pētījumā iesaistītie bērni ticēja vairāk nekā vienaudžu sacītajam (Field \& Lawson, 2003; Fisak \& Grills-Taquechel, 2007). Tātad, ja vecāki nesniedza pietiekoši daudz informācijas vai šì informācija bija nekonkrēta, vai izraisīja bailes, bet vienlaikus vecāki izrādīja vai verbāli pauda trauksmi, bija lielāka iespēja, ka bērns pie zobārsta demonstrēs trauksmainu uzvedību. Verbāli draudīga informācija radīja ilgtermiņa izmaiņas bērnu uztverē un apziṇā (angliski - cognition), kā arī radīja uztveres kḷūdas un izvairīšanās uzvedību (Field \& Lawson, 2008). Tomēr pastāvēja iespēja, ka bērna bailes un trauksmi pastiprināja nevis tikai informācijas pārneses veids, bet gan informācija kombinācijā ar vecāku trauksmainu uzvedību (Fisak \& Grills-Taquechel, 2007). Nozīme varētu būt arī vecumam, kurā negatīvā informācija tika sniegta (Fisak \& Grills-Taquechel, 2007). Saskaņā ar psihoanalītisko teoriju par bailēm no zobārsta pirmsskolas vecuma bērni reti pārdzīvo reālas bailes, drīzāk neirotisku trauksmi, kuras pamatā ir nevis ārējs, bet gan iekšējs apdraudējums (angliski - internal danger) - bailes zaudēt māti, bailes no ievainojumiem, sāpēm un bezpalīdzības (Freeman, 2007). Savukārt jaunākā skolas vecuma bērniem vairāk raksturīgas konkrētas bailes (bailes no dzīvniekiem, sociālās bailes) (Kuenkel, 2000). 
Vecākiem ar lielākām bailēm no zobārsta bija raksturīgs zemāks sociālekonomiskais stāvoklis, vājākas zināšanas par mutes veselību un novēlotāki apmeklējumi pie zobārsta, kā arī sliktāka bērnu mutes veselība, jo, iespējams, ja vecāki nesaprata informāciju par bērna diagnozi un ārstēšanas plānu, tas varēja paaugstināt viṇu trauksmes līmeni (Shin et al., 2014). Šins ar līdzautoriem norādīja, ka svarīgi bija saprast, kā informāciju par mutes veselību padarīt publiski pieejamāku, lai vecāki ar nepietiekošām zināšanām to varētu uztvert (Shin et al., 2014). Autori atzina, ka ar vecākiem, kuriem bija sliktākas zināšanas par mutes veselību, bija nepieciešama efektīva komunikācija, lai samazinātu trauksmes un baiļu no zobārsta līmeni, jo vizuāla informācija palīdzēja labāk izglītot vecākus (Vann et al., 2010; Shin et al., 2014). Citā pētījumā tika noskaidrots, ka 60\% pieaugušo amerikāņu tika izmantojuši internetu, lai atrastu informāciju par veselības jautājumiem (Fox, 2011). Informācija par bērna (pirmo) vizīti pie zobārsta bija viegli atrodama internetā, tomēr ne visos gadījumos tā bija precīza (Yeap \& Slack-Smith, 2013). Ja oficiālajās (publiskajās un valsts uzturētajās) mājaslapās informācija par bērna vizīti pie zobārsta pilnībā saskanēja ar starptautiskajām vadlīnijām, tad speciālistu (zobārstu) un, vēl jo vairāk, neprofesionāļu (vecāku) savstarpējā atbalsta forumos šī informācija atbilda minētajām vadlīnijām tikai 69\% gadījumu un bija pieejama tikai 28\% mājaslapu (Yeap \& Slack-Smith, 2013). Autori norādīja, ka visvairāk internetā pieejamā informācija par bērna vizīti pie zobārsta bija saistībā ar bērna mutes higiēnas instrukcijām (45\%), procedūrām bērna pirmajā vizītē pie zobārsta (53\%) un bērna sagatavošanu pirmajai vizītei pie zobārsta (40\%) (Yeap \& Slack-Smith, 2013).

Tātad, jo precīzāka un pozitīvāka bija informācija, ko vecāki sniedza bērnam pirms vizītes pie zobārsta, jo mazākas bija bērna BTZ. Savukārt negatīva informācija par neitrālu objektu, jo īpaši no bērnam nozīmīgas personas, palielināja bērna trauksmi. Precīzāku informāciju par zobu kopšanu un ārstēšanu varēja iegūt no profesionāļiem vai speciālistu interneta vietnēm nekā no draugiem vai pazin̄ām.

\subsubsection{Stress ğimenē un tā pārvarēšanas veidi}

Kopumā pētījumu par bērna vai gimenes stresa saistību ar bērnu bailēm no zobārsta bija ļoti maz. Nesenā pētījumā netika atrasta statistiski nozīmīga saistība starp ǵimenes emocionālajām problēmām, bērna bailēm no zobārsta un bērna uzvedību zobārsta kabinetā (Paryab \& Hosseinbor, 2013). Citā pētījumā savukārt atrasta statistiski nozīmīga saistība starp mazu (3-6 gadus vecu) bērnu trauksmi/satraukumu ikdienišķāas stresa situācijās un bērna bailēm no zobārsta (Vogels et al., 2011). 


\subsubsection{Sociālekonomiskie faktori}

Deviņgadīgiem bērniem, kuru vecākiem bija zemāks izglītības līmenis, bija lielāka tendence baidīties no zobārsta, nekā tiem, kuru vecākiem bija augstāka izglītība (Rantavuori et al., 2009). Citā pētījumā tika atrasta statistiski nozīmīga saistība starp mātes izglītību, bērna bailēm no zobārsta un bērna uzvedību zobārsta kabinetā, tomēr šādas saistības nebija ne ar tēva izglītību, ne ar mātes un tēva vecumu (Paryab \& Hosseinbor, 2013). Klingberga ar līdzautoriem nekonstatēja saistību ne ar vecāku vecumu, ne ar viena vecāka gímeni, ne ar nodarbinātības līmeni, ne valodu, kādā gimenē runā (Klingberg et al., 1994). Perecs ar līdzautoriem neatrada statistiski nozīmīgu sakarību starp bērnu bailēm no zobārsta un vecāku vecumu, izglītību vai dzimšanas vietu (Peretz et al., 2004). Netika atrasts neviens pētījums, kas pārbaudītu „organizētu” pirmsskolas vecuma bērnu baiļu no zobārsta līmeņa atšķirības no „neorganizētu” pirmsskolas vecuma bērnu baiļu no zobārsta līmeņa.

Bērniem, kas apmeklēja zobārstniecības klīnikas ar zemākiem sociālekonomiskiem standartiem, bija augstāks baiļu no zobārsta līmenis (Klingberg et al., 1994). Bērniem no ğimenēm ar zemu sociālekonomisko stāvokli biežāk bija raksturīgi uzvedības traucējumi pie zobārsta (Arnrup et al., 2002; Gustafsson et al., 2007). Vecāku zemāks sociālekonomiskais stāvoklis bija saistīts ar lielākām bailēm no zobārsta, sliktāku bērnu mutes veselību un vājākām zināšanām par mutes kopšanu (Shin et al., 2014). Stipras bailes no zobārsta korelēja ar vecāku nodarbinātību nepilnu darba laiku vai bezdarbu, kā arī ar (otriem) zemākiem ienākumiem (Armfield et al., 2007). Ievērojami lielākai daļai bērnu ar uzvedības traucējumiem zobārsta kabinetā vecāki bija ar zemāku sociālekonomisko stāvokli nekā kontrolgrupā (59\% pret 29\%), kā arī ievērojami vairāk bērnu ar uzvedības traucējumiem zobārsta kabinetā vecāki dzīvoja šķirti, salīdzinot ar kontrolgrupu (50\% pret 79\%) (Arnrup et al., 2007).

Ģimenes vecākajiem bērniem bija raksturīga sliktāka uzvedība zobārsta kabinetā, salīdzinot ar citiem bērniem (Pai et al., 2015). Autori šīs uzvedības problēmas skaidroja ar to, ka vecākie bērni kādu brīdi bija bijuši uzmanības centrā, bet pēc jaunāko bērnu piedzimšanas tika „,nogrūsti no troņa”, kas izraisīja ievainojamību un stresu dažādās sarežğītās situācijās (Pai et al., 2015). Vecākajiem bērniem un vien̄̄gajiem bērniem bija statistiski nozīmīgi augstāka klīniskā trauksme zobārsta krēslā, salīdzinot ar citiem bērniem (Lee et al., 2008). Vien̄̄gajiem bērniem bija statistiski nozīmīgi sliktāka uzvedība zobārsta krēslā nekā pārējiem bērniem (Lee et al., 2008). Tomēr Perecs ar līdzautoriem neatrada statistiski nozīmīgu saistību starp bērnu bailēm no zobārsta un bērnu skaitu g̊imenē (Peretz et al., 2004). 
Bērniem no paplašinātām ǵimenēm (tādas gímenes, kurās dz̄ivo vecāki, bērni un citi ǵimenes locekḷi, piemēram, vecvecāki) piemita mazāk uzvedības problēmu nekā bērniem no nukleārām gímenēm (tādas, kurās dzīvo tikai vecāki un bērni). Autori to saistīja ar iemācītu lielāku pacietību, toleranci un sadarbošanos (Pai et al., 2015). Savukārt Supraba ar līdzautoriem neatrada saistību ne starp bailēm no zobārsta un gimenes tipu (nukleārā vai paplašinātā), ne starp bailēm no zobārsta un ğimenes vecākā bērna statusu (Suprabha et al., 2011). Tomēr pētījums parādīja statistiski nozīmīgu baiļu no zobārsta saistību ar brāḷu vai māsu esamību ǵimenē (Suprabha et al., 2011). Bērniem no šķirtām ǵimenēm biežāk bija raksturīgi uzvedības traucējumi pie zobārsta (Arnrup et al., 2002). Juzugullu ar līdzautoriem konstatēja, ka pieaugušu sieviešu atrašanās laulībā un bērnu esamība bija nozīmīgi faktori, kas saistīti ar pacientu bailēm no zobārsta (Yuzugullu et al., 2010).

Savukārt Milsoma un līdzautoru pētījumā netika konstatēta sociālekonomisko faktoru ietekme uz bērnu bailēm no zobārsta (Milsom et al., 2003). Mērštets ar līdzautoriem neatrada atšķirīibas pieaugušo sociālekonomiskajā stāvoklī (Mehrstedt et al., 2004). Stenebrandas un līdzautoru pētījums parādīja, ka 15 gadus vecu pusaudžu vispārējām bailēm un/vai trauksmei, kā arī attieksmei pret zobārstniecības personālu ir lielāka nozīme nekā tādiem sociāldemogrāfiskajiem faktoriem kā vecums un vecāku izglīīība (Stenebrand et al., 2013).

Tādējādi lielākajā daļā pētījumu rezultāti par tādu sociālekonomisko faktoru kā vecāku izglītība, vecums, ienākumi, bērnu skaits ğimenē, šķirtas vai paplašinātas gímenes esamības saistību ar BTZ bija pretrunīgi.

\subsection{Ar bailēm no zobārsta un mutes veselību saistītie faktori}

Šajā nodaḷā tiks apskatīta bērnu baiļu un trauksmes zobārstniecībā saistība ar mutes veselību, zobu kopšanas paradumiem, kā arī ar vispārējo veselības stāvokli. Izvairīšanās no zobārsta apmeklējuma ir bieži sastopama problēma pacientiem, kuri baidās no zobārsta (Berggren et al., 1984). Iespējams, tāpēc nereti šādiem pacientiem ir ievērojami sliktāka mutes veselība, nekā pacientiem, kuri nebaidās no zobārsta un regulāri to apmeklē (Armfield et al., 2007; Armfield et al., 2009). Tomēr bailīgie pacienti nevis pastiprināti kopj savus zobus, bet gluži otrādi - nepievērš tiem vērību un atstāj novārtā. Arī bieži un/vai traumatiski vispārējo ārstu apmeklējumi var ietekmēt bērna attieksmi pret zobārstu, it īpaši tad, ja jau agrīnā vecumā bērna tikšanās ar medicīnas darbiniekiem ir bijušas saistītas ar injekciju izdarīšanu. 


\subsubsection{Saistība ar mutes veselību}

Viena no aktuālākajām problēmām bērnu un arī pieaugušo zobārstniecībā joprojām ir tā, ka bailīgie pacienti pēc iespējas cenšas izvairīties no zobārsta apmeklējuma, novilcina vizītes, līdz zobu sāpes kḷūst neciešamas, apmeklē zobārstu tikai tad, kad ir nepieciešama sāpju remdēšana, bet rutīnas zobu ārstēšana netiek turpināta līdz zobi ir pilnībā sanēti.

Viens no pirmajiem lielākajiem pētījumiem par izvairīšanos no zobārsta tika publicēts 1984. gadā (Berggren et al., 1984), kurā tika secināts, ka galvenais iemesls šai sociālajai parādībai bija paaugstinātas bailes no zobārsta, kā arī sāpīga zobu ārstēšana, kā rezultātā nākošā vizīte pie zobārsta tika atlikta. Berggrēns arī izvirzīja teoriju par baiḷu no zobārsta „apburto loku” (Berggren et al., 1984). Savukārt Armfîlds ar kolēǵiem, pārbaudot hipotēzi par „apburto loku” starp bailēm no zobārsta, izvairīšanos no vizītēm un sliktāku mutes stāvokli, pierādīja, ka pacientiem ar lielākām bailēm no zobārsta bija raksturīgs ilgāks laiks kopš iepriekšējās vizịtes un lielāks vidējais laiks starp vizītēm (Armfield et al., 2007). Ievērojami vairāk cilvēku ar izteiktām bailēm no zobārsta vizīti nozīmēja tikai, ja viṇiem sāpēja zobi vai radās problēmas ar tiem (Armfield et al., 2007). Starp respondentiem, kuri parasti apmeklēja zobārstu neatliekamās palīdzības dēḷ, procentuāli bija daudz vairāk tādu, kam piemita ļoti augsts baiļu līmenis, salīdzinot ar respondentiem, kuri zobārstu parasti apmeklēja profilaktisku pārbaužu nolūkā (Armfield et al., 2007). Pusaudži ar lielākām bailēm no zobārsta statistiski nozīmīgi biežāk atcēla vizītes pie zobārsta vai neieradās uz tām (Bedi et al., 1992). Arī 5 gadus veci bērni, kam bija bailes no zobārsta, trīs reizes biežāk bija neregulāri zobārstu apmeklētāji (Milsom et al., 2003). Vecāki, kuriem bērnībā bijusi negatīva pieredze pie zobārsta, mēdza novilcināt arī savu bērnu rutīnas zobu ārstēšanu, līdz bija iespējama tikai sāpošā zoba ekstrakcija (Smith \& Freeman, 2010).

Tādējādi bailīgiem pacientiem var būt augstāks KPE indekss (vairāk kariozu, plombētu un ekstrahētu zobu). To apstiprina arī dažādos laikos veikti pētījumi. Koens aptaujāja 938 jūras kājniekos rekrutētus jaunus vīriešus. Grupā ar augstu BTZ (bailēm un trauksmi zobārstniecībā) bija ievērojami vairāk bojātu zobu nekā grupā ar zemu BTZ, savukārt plombēto un ekstrahēto zobu skaits statistiski nozīmīgi neatšş̄īās (Cohen, 1985). Līdzīgi rezultāti tika konstatēti pētījumā ar 19 līdz 54 gadus veciem pieaugušiem kareivjiem Vācijā (Eitner et al., 2006). Citā pētījumā par Vācijas pieaugušo populāciju tika konstatēts, ka bailīgiem pacientiem bija apmēram divas reizes vairāk kariozu zobu un apmēram četras reizes vairāk sabrukušu zobu jeb sakņu (Mehrstedt et al., 2004). Norvēǵijā 35 līdz 64 gadus veciem pieaugušajiem ar ievērojamām bailēm no zobārsta tika konstatēts statistiski nozīmīgi vairāk bojātu zobu virsmu, bojātu zobu un ekstrahētu zobu, kā arī mazāk plombētu virsmu un 
plombētu zobu, funkcionālu virsmu un funkcionālu zobu, bet nebija atšşirības kopējā KPE abās grupās (Schuller et al., 2003). Visplašāko pētījumu veica Armfīlds 2009. gadā, aptaujājot vairāk nekā 5000 respondentus Austrālijā un secinot, ka bailes no zobārsta pieaugušajiem bija saistītas ar vairāk karioziem un ekstrahētiem zobiem, kā arī augstāku KPE. Savukārt baiļu no zobārsta saistība ar plombētiem zobiem bija apgriezta U veida, t. i., ja respondentiem bija nedaudz bail, tad plombēto zobu skaits pieauga, savukārt baiļu pakāpei turpinot pieaugt, plombēto zobu skaits ievērojami samazinājās (Armfield et al., 2009). Tomēr atsevišksos pētījumos netika atrasta korelācija starp pieaugušo bailēm no zobārsta un KPE (Samorodnitzky \& Levin, 2005; Yuzugullu et al., 2014).

Akbaj-Oba ar līdzautoriem pētīja BTZ prevalenci un saistību ar zobu kariesu 7-11 gadus veciem turku bērniem. KPE rādītāji bērniem ar palielinātām bailēm no zobārsta bija 1,5 reizes augstāki nekā bērniem bez tām (Akbay-Oba et al., 2009). Bēna pētīja 6 līdz 12 gadus vecu bērnu bailes no zobārsta un atrada atšķirību starp bailīgo bērnu un kontrolgrupas bērnu zobu stāvokli tikai atsevišķās vecuma grupās (Beena, 2013). KPEz bija statistiski nozīmīgi augstāks 6 un 10 gadus veciem bailīgajiem bērniem, savukārt kpez nozīmīgi atšķīrās 6 un 9 gadu vecumā bailīgo bērnu grupā. Pārējās vecuma grupās, tāpat arī visās grupās kopumā nebija statistiski nozīmīgu atšķirīibu attiecībā uz piena un pastāvīgo zobu stāvokli starp bailīgajiem bērniem un kontroles grupu (Beena, 2013). Klingbergas un līdzautoru pētījums parādīja, ka 4-11 gadus veciem bērniem ar augstu baiḷu līmeni bija statistiski nozīmīgi vairāk kariozu zobu un mazāk plombētu zobu nekā pārejai grupai (Klingberg et al., 1995). BTZ neatšķīrās 4-11 gadus veciem bērniem, kas bija saṇēmuši vietējo anestēziju, un pārējai grupai. Tomēr tiem, kam bija plombēti zobi, bija augstāki baiļu rādītāji nekā tiem, kam zobi nebija ārstēti (Klingberg et al., 1994). Bedi ar kolēgiem konstatēja, ka 14 gadus veciem pusaudžiem, kas baidījās no zobārsta, bija statistiski nozīmīgi augstāks KPE, kā arī vairāk plombētu un ekstrahētu zobu, savukārt kariozo zobu skaita pārsvars nesasniedza statistiskas nozīmības līmeni (p < 0,05) (Bedi et al., 1992). Kopējā kariesa pieredze bērniem ar bailēm no zobārsta bija par 44\% augstāka. Tāpat grupai ar bailēm no zobārsta bija statistiski nozīmīgi mazāks zobu skaits un mazāks tādu bērnu skaits, kam uz zobiem likti fisūru silanti (Bedi et al., 1992). Krugere ar līdzautoriem pierādīja, ka bērniem ar augstiem baiḷu no zobārsta rādītājiem bija statistiski nozīmīgi augstāka kariesa prevalence, savukārt regresijas analīze pierādīja, ka bailes no zobārsta statistiski nozīmīgi prognozē kariesa sastopamību vecumā no 15 līdz 18 gadiem (Kruger et al., 1998). Šksērsgriezuma pētījums Anglijā parādīja, ka, salīdzinot ar bērniem, kam nav bail no zobārsta, bailīgiem bērniem piecu gadu vecumā bija vismaz divas reizes augstāks kpe un 3,5 reizes biežākas zobu ekstrakcijas, bet statistiski nozīmīgas atšķirības netika atrastas saistībā ar plombēšanas pieredzi (Milsom et al., 2003). 
Vairāku zobu ekstrakcijas varēja palielināt vai izraisīt bailes no zobārsta arī jauniešu vecumā, ja tās tika uztvertas kā negatīva pieredze (Thomson et al., 2000). Augstāki kpe rādītāji 5 gadu vecumā varēja norādīt uz lielāku potenciālu bērnu bailēm no zobārsta 10 gadu vecumā (Raadal et al., 2002).

Savukārt Vignesas un līdzautoru pētījumā 8-9 gadus veciem bērniem statistiski nozīmīgi neatšķīrās kariesa aktivitāte un neārstētu kariozu zobu daudzums bērniem ar augstu un zemu baiḷu no zobārsta līmeni (Vignehsa et al., 1990). Arī Tāni un līdzautoru pētījumā 12-15 gadus veciem pusaudžiem netika atrasta saistība starp bailēm no zobārsta, zobu stāvokli (KPEz) un smaganu veselību (gingivālo indeksu) (Taani et al., 2005).

Brukiene ar līdzautoriem konstatēja, ka 15-16 gadus veciem pusaudžiem Lietuvā plombēto un ekstrahēto zobu skaits statistiski nozīmīgi korelēja ar baiļu no zobārsta rādītājiem pāru main̄̄go analīzē, tomēr vairāku mainīgo regresijas analīzē statistiski nozīmīgs izrādījās tikai plombēto zobu skaits, bet ekstrahēto zobu skaits tika izslēgts (Brukiene et al., 2006). Savukārt Igaunijā veiktā pētījumā 8 līdz 11 gadus veciem bērniem tika konstatēts, ka kpe/KPE un kariozo zobu skaits bija statistiski nozīmīgi saistīts ar bērnu (kopējām) bailēm no zobārsta, kā arī ar bailēm no invazīvām procedūrām (Saag \& Olak, 2014). Latvijā līdz šim nebija veikti kvalitatīvi pētījumi ne par bērnu, ne pieaugušo BTZ. Tāpat Latvijā nav izpētīts, cik lielā mērā bērnu bailes no zobārsta ietekmē mutes dobuma stāvokli. Vien̄̄gi Bērziņas promocijas darbā par kariesa un periodonta patologijiju izplatību bērniem un pusaudžiem Latvijā, aplūkojot skolēnu aptaujas datus, norādīts, ka 11, 12, 13 un 15 gadus veciem bērniem galvenais iemesls, kas atturēja no zobārsta apmeklējuma, bija bailes no sāpēm un ārstēšanas, un šādu atbildi bija devuši 45\% no aptaujātajiem pusaudžiem (Bērziņa, 2004).

Tātad lielākajā daḷā pētîjumu bērnu bailes no zobārsta korelēja ar augstāku KPE, lielāku kariozo un/vai ekstrahēto zobu skaitu un mazāku plombēto zobu skaitu.

\subsubsection{Saistība ar mutes dobuma kopšanas paradumiem}

Zobu tīrīšana vienu reizi dienā vai mazāk bija saistīta ar bailēm pat no mazinvazīvām zobārstniecības procedūrām (Rantavuori et al., 2009). Aitners ar līdzautoriem 2006. gadā nekonstatēja atšksirības CPITN indeksā respondentiem ar bailēm no zobārsta un bez tām (Eitner et al., 2006). Periodontīts un gingivīts pieaugušajiem Austrālijā nebija saistîts ar bailēm no zobārsta (Armfield et al., 2009). Šina un līdzautoru pētījums parādīja, ka vecāku vājākas zināšanas par mutes veselību bija saistītas ar viņu bailēm no zobārsta un sliktāku bērnu mutes veselību (Shin et al., 2014). 


\subsubsection{Saistība ar vispārējo veselības stāvokli}

Vispārējā medicīnas aprūpē bieži sastopami akūti, īstermiņa vai ilgtermiņa posttraumatiskie simptomi. Trauma agrīnos dzīves gados var būt saistîta ar somatiskiem simptomiem pēc daudziem gadiem. Smaga fiziska slimība var darboties kā generalizēts stress, kas veicina ar iepriekšējo, parasti ar nemedicīnisku traumu saistīto posttraumatisko traucējumu atgriešanos. Smaga fiziska saslimšana vai tās ārstēšana var izraisīt posttraumatiskus simptomus. Šie simptomi bieži rodas pēc biedējošiem medicīniskiem notikumiem, piemēram, smagas slimības, plašu izmeklējumu un uzstājīgas (angliski demanding) ārstēšanas rezultātā (Mayou \& Smith, 1997). Fobiskas sūdzības un/vai izvairī̌sanās no ārstēšanas, bailes no slimnīcām un citiem medicīniskās aprūpes aspektiem, kā arī no ievainojumiem/asinīm, var būt daḷa no posttraumatiskajiem traucējumiem vai atseviškss sindroms (Mayou \& Smith, 1997). Pacientiem ar izteiktām bailēm no zobārsta daudzkārt biežāk anamnēzē bija medicīniska rakstura trauma, salīdzinot ar kontrolgrupas pacientiem. Tāpat šiem pacientiem biežāk parādījās posttraumatiskā stresa traucējumi (de Jongh et al., 2006).

Lielākā daļa medicīnisko un arī zobārstniecības baiļu un traumatisko situāciju ir bijušas saistītas ar injekcijām (Milgrom et al., 1997). Milgroma un līdzautoru pētījumā gandrīz 25\% Vašingtonas universitātes studentu un darbinieku bija vismaz viena veida bailes no injekcijām, un gandrīz 5\% no pētījuma dalībniekiem to dēl izvairījās, atcēla vai neieradās vizìtē pie zobārsta (Milgrom et al., 1997). Asiņu-ievainojumu-injekciju fobija (angliski blood-injury-injection phobia jeb BII) bija viena no fobijām, kas klasificēta DSM-IV. Tā, līdzīgi kā odontofobija, bija saistīta ar normālu stimulu nepareizu interpretāciju jeb katastrofiskām, aplamām domām par to, ka injekcijas cilvēkam var izraisīt fiziski, psihiski vai sociāli negatīvas un/vai neatgriezeniskas sekas (Vika \& Agdal, 2013). Asiņu-ievainojumuinjekciju fobija varēja būt gan izolēta, gan summēties ar bailēm no zobārsta (de Jongh et al., 1998). Bailēm no injekcijām bija četras dimensijas, no kurām biežāk sastopamās bija bailes no sāpēm injekcijas izdarīšanas laikā vai no injekcijas radītā ievainojuma. Retāk cilvēki baidījās inficēties caur injekcijām vai saskarties ar blakusefektiem (Milgrom et al., 1997). Daži cilvēki baidījās no tirpuma sajūtas (Armfield \& Milgrom, 2011), tomēr bailes no injekciju radītā tirpuma bija tikai četrdesmit pirmais no 67 piedāvātajiem stimuliem pie zobārsta (Oosterink et al., 2008).

Bērnu bailes no medicīniskajām pieredzēm bija saistītas ar viṇu distresu atsevišķu sāpīgu procedūru, piemēram, imunizācijas laikā (Broome et al., 1994), bet ne vienmēr bija saistītas ar bērna uzvedību stresa laikā. 
Bieža saskare ar slimnīcām (angliski - high hospital exposure) pavēra lielāku iespēju rasties un attīstîties medicīniskajām bailēm (tiešā nosacījuma refleksa veidošanās) un, attiecīgi, arī bailēm no zobārsta (Davey, 1989).

Nesenā pētījumā pierādīts, ka 8 līdz 16 gadus veciem bērniem ar kardioloǵiskām saslimšanām bija statistiski nozīmīgi augstāks baiļu no zobārsta līmenis nekā kontrolgrupai, un šiem rezultātiem bija saistība ar bērnu hospitalizācijas skaitu (daudzumu) (Hollis et al., 2015). Pētījuma grupai arī bija statistiski nozīmīgi lielāks veikto vispārējo anestēziju skaits, bet autori nevarēja skaidri secināt, vai š̄ saistība bija baiḷu no zobārsta cēlonis jeb veicinošs faktors vai drīzāk sekas (Hollis et al., 2015). Bērniem, kuri iepriekš tikuši hospitalizēti, bija sliktāka (mazāk kooperatīva) uzvedība zobārsta krēslā (Pai et al., 2015). Iespējams, bērniem, kuri bieži slimo, bija grūtāk pārvarēt stresu (Pai et al., 2015, atsaucoties uz Holst et al., 1988). Deviņgadīgiem bērniem, kuri bērnībā bieži slimoja (piemēram, ar hronisku vidusauss iekaisumu, trombocitopēniju vai juvenīlo diabētu) un saskārās ar invazīvām medicīniskām procedūrām (piemēram, ar adenektomiju), bija lielākas bailes no zobārsta nekā kontrolgrupai (Karjalainen et al., 2003). Arī astma un ausu problēmas (piemēram, vidusauss iekaisums) palielināja 6 - 8 gadus vecu bērnu baiļu no zobārsta risku un izplatību (Wogelius et al., 2003). Horvātijā veiktā pētījumā piecus līdz divpadsmit gadus veciem bērniem bija ļoti augsta, statistiski nozīmīga korelācija ar iepriekšēju traumatisku medicīnisko pieredzi (Majstorovic et al., 2001). Tomēr regresijas analīze parādīja, ka iepriekšējā traumatiskā medicīniskā pieredze izskaidroja tikai 33-43\% baiļu no zobārsta variācijas (Majstorovic et al., 2001).

Citā nesen Indijā veiktā pētījumā netika atrasta saistība starp iepriekšēju hospitalizāciju un bērnu bailēm no zobārsta (Paryab \& Hosseinbor, 2013). Tāpat šajā pētījumā netika atrasta saistība starp traumējošu negadījumu pieredzi, bērna bailēm no zobārsta un bērna uzvedību zobārsta krēslā (Paryab \& Hosseinbor, 2013). Suprabas un līdzautoru pētījumā netika atrasta 7-14 gadus vecu bērnu baiļu no zobārsta tieša saistība ar nesenu vizīti pie pediatra vai iepriekšēju hospitalizāciju (Suprabha et al., 2011). Tomēr, veicot bināro logistiskās regresijas analīzi, pediatra apmeklējums pēdējā gada laikā, iepriekšeja hospitalizācija, iepriekšēja vizīte pie zobārsta, nepatīkama pieredze pirmajā vizītēe un bērna vecums bija faktori, kas statistiski nozīmīgi ietekmēja bērna bailes no zobārsta (Suprabha et al., 2011). Savukārt bērna uzvedību pie zobārsta statistiski nozīmīgi ietekmēja nepatīkama pieredze zobārsta klīnikā un bērna vecums (Suprabha et al., 2011).

Nebija atrastas atšķirības bērnu baiļu no zobārsta līmenī bērniem ar hemofiliju un bez tās, lai gan šie bērni dzīvoja ar nepārtrauktu dzīvības apdraudējumu un biežām vizītēm pie ārstiem, kā arī invazīvām medicīniskām procedūrām (Dogan et al., 2013). Kaut arī ar hemofiliju slimiem bērniem bieži bija bailes no medicīniskā personāla, adatām un asiņošanas, 
autori apgalvoja, ka lielāka nozīme bija akūtu sāpju esamībai pirms veiktās zobu ekstrakcijas (Dogan et al., 2013). Līdzīgi rezultāti tika iegūti 6 līdz 14 gadus veciem bērniem pēc audzēju ārstēšanas - ne baiḷu no zobārsta izplatība, ne bailes no zobārsta statistiski nozīmīgi neatš̌k̄īās bērniem, kas ārstējušies no audzējiem, un veseliem bērniem (Wogelius et al., 2009). Pētījuma autori rezultātu skaidroja tādējādi, ka vēža ārstēšanas laikā bērni iemācījās mediķu komandu uztvert kā draugus, jo sadarbojās ar viṇiem ilgstoši, tādēḷ līdzịgi uztvēra arī citus mediḳus (Wogelius et al., 2009).

Bērni, kas savu iepriekšējo medicīnisko pieredzi uztvēra kā pozitīvu, sadarbojās arī zobārstniecības klīnikā (Wright, 2000; Suprabha et al., 2011). Iepriekšējo vizīšu emocionālā kvalitāte bija nozīmīgāka nekā viz̄̄šu skaits (Suprabha et al., 2011).

Tātad bailes no zobārsta varēja būt saistītas ar medicīniskām bailēm, ja bērniem bija vai bija bijušas hroniskas, smagas saslimšanas vai bieži jāapmeklē ārsti, kā arī tad, ja bija bijusi kāda traumatiska medicīniska pieredze, piemēram, invazīva ārstēšana vai medicīniska manipulācija, kas veikta piespiedu kārtā. Tāpat bailes no zobārsta varēja parādīties saistībā ar sadzīvisku fizisku vai psiholog̣isku traumu. 


\section{MATERIĀLS UN METODES}

\subsection{Pētījuma dalībnieki}

Pētîjumā piedalījās 260 nejauši izvēlēti bērni vecumā no 4 līdz 12 gadiem (vidējais vecums bija 7,94 (SD = 2,60) gadi, 133 meitenes un 127 zēni) un viņu vecāki. Pilns datu komplekts ar anketām, kā arī ar mutes dobuma stāvokḷa un bērna uzvedību zobārsta kabinetā novērtējumu tika iegūts no 240 dalībniekiem (vidējais vecums bija 7,96 gadi, SD = 2,61, tai skaitā 122 meitenes un 118 zēni). Anketas vecāki aizpildīja latviešu vai krievu valodā (attiecīgi 192 un 48). Tāpēc 20 dalībnieki (vidējais vecums bija 7,70 gadi, SD = 2,45, tai skaitā 11 meitenes un 9 zēni) piedalījās starpkultūru pētījumā, lai apstiprinātu latviešu un krievu valodas anketu variantu datu savienojamību. Vecāki, kuri vienlīdz labā līmenī pārvaldīja gan latviešu, gan krievu valodu aizpildīja anketas divas reizes ar 7-62 dienu intervālu. Vienpadsmit vecāki pirmo reizi anketu aizpildīja dzimtajā valodā, bet otro - otrajā valodā. Deviņi vecāki anketas aizpildīja pretējā kārtībā. Starpkultūru pētījumā respondentu sniegtās atbildes latviešu valodā statistiski nozīmīgi neatšķīrās no sniegtajām atbildēm krievu valodā, un otrādi. Šie dalībnieki tika aptaujāti ārpus zobārsta kabineta, tāpēc netika veikta mutes dobuma apskate un bērna uzvedības novērtējums. Ši iemesla dēḷ visu atbilžu analīze tika veikta ar 240 respondentu datiem.

\subsection{Pētījuma procedūra (norise)}

Pirms pētījuma tika iegūta Rīgas Stradiṇa universitātes Ētikas komitejas atḷauja to veikt un apliecinājums, ka darbs atbilst Helsinku konferences kritērijiem. Pētījumu veica viens zobārsts (darba autore) no 2010. gada decembra līdz 2013. gada septembrim Rīgas Stradiña universitātes Stomatoloǵijas institūta Bērnu nodaḷā. Darba autore uzrunāja pētījuma potenciālos dalībniekus atbilstošā vecumā, kas pētījuma norises laikā bija ieradušies uz rutīnas vizīti pie zobārsta, un viņu vecākus. Dalībnieki netika rekrutēti mērķtiecīgi (piemēram, īpaši uzaicinot uz vizīti mutiski, telefoniski vai ar vēstules palīdzību), tomēr pētījuma izlase tika aptuveni izlīdzināta pēc vecuma un dzimuma. Sakarā ar to, ka bija plānots lietot faktoranalīzi, minimālais dalībnieku skaits bija 200. Kad respondentu skaits pārsniedza 200 un kādā vecuma grupā bija pietiekoši daudz respondentu ( $\geq 15)$, dalībnieki tajā vairs netika uzrunāti. Pacienti netika iesaistīti arī tad, kad ārstam vai potenciālajiem respondentiem nebija laika, kā arī tad, ja vecāki atteicās piedalīties. Tomēr šie gadījumi netika īpaši reǵistrēti. Atteikums piedalīties pētījumā neietekmēja bērna iespēju saņemt zobārstniecības 
pakalpojumus. Ja vecāki piekrita iesaistīties pētījumā, viņi tika informēti par tā norisi. Pēc informētās piekrišanas atļaujas parakstī̌sanas vecāki aizpildīja pētījuma anketas (pēc izvēles latviešu vai krievu valodā) pirms bērna zobu ārstēšanas vai tās laikā. Pēc bērna iesēšanās zobārsta krēslā tika noteikts zobu stāvoklis, kā arī tika novērtēta bērna uzvedība zobārsta krēslā (pēc Frankla skalas). Zobu stāvokḷa un bērna uzvedības novērtējumu veica viens zobārsts - pētījuma autore. Pirmās vizītes un pirmās ārstēšanas (proti, zobu higiēnas, plombēšanas un/vai ekstrakcijas) laiks un fakts tika fiksēts retrospektīvi, saskaņā ar ierakstu pacienta ambulatorajā kartin̄ā (ja bija iespējams). Ambulatorā karte tika izmantota arī zobu stāvokḷa precizēšanai, piemēram, zobu ekstrakciju gadījumā.

\subsection{Pētījuma instrumenti (metodes)}

Vecāki novērtēja savu baiļu līmeni ar Modificēto zobārstniecības trauksmes skalu (angliski - Modified Dental Anxiety scale jeb MDAS, Humphris et al., 1995, adaptētu latviešu valodā, Kroniņa, 2008). Anketa saturēja piecus jautājumus par vecāku izjūtām pirms zobārstniecības procedūras vai tās laikā. Atbildes tika dotas saskaṇā ar oriğinālo Koras zobārstniecības baiḷu skalu (angliski - Corah Dental Anxiety scale), tomēr, apstrādājot datus, atbildes tika novērtētas Likerta skalā no 1 („,brīvi”) līdz 5 („,nosvīstu vai justu fizisku nelabumu”). Iespējamais punktu skaits bija no 5 līdz 25. Metodes ticamība jeb Kronbaha $\alpha=0,85$.

Bērnu BTZ tika novērtētas ar Bērnu baiḷu pārskata zobārstniecības apakšskalas vecāku formu (angliski - Children Fear Survey Schedule - Dental Subscale jeb CFSS-DS, Cuthbert \& Melamed, 1982, adaptētu latviešu valodā, Kroniņa, 2008). Anketā tika uzdots jautājums „Cik lielā mērā Jūsu bērnam ir bail?” un uzrādīti 15 ar zobārstniecību un medicīnu saistīti faktori, kas bija jānovērtē Likerta skalā no 1 („,nemaz nebaidās”) līdz 5 („,̧̣oti baidās”). Iespējamais punktu skaits bija no 15 līdz 75. Metodes ticamība jeb Kronbaha $\alpha=0,91$.

Dažādi psihosociālie faktori, kas varēja ietekmēt bērna attieksmi un uzvedību, kā arī veicināt bailes no zobārsta, tika novērtēti ar pētījuma ietvaros oriǵināli izstrādātu bērnu vecāku aptauju. Tajā bija septiṇi bloki: sociālekonomiskais/sociāldemogrāfiskais (ğimenes locekḷu skaits, bērnu skaits ǵimenē, vecāku vecums, izglītība, nodarbinātība, ienākumu līmenis), bērna medicīniskā pieredze un attieksme (hronisku slimības, slimošanas un ārstu apmeklējumu biežums, traumatiska pieredze ar ārstiem, bērna attieksme pret medicīnisko personālu), zobārstniecības pieredze un attieksme (bērna vecums pirmās vizītes pie zobārsta laikā, kad bērns tika vests pie zobārsta, līdzšinēja zobu ārstēšana, negatīva pieredze pie zobārsta un tās pārvarēšana, bērna attieksme pret zobu ārstēšanu), vecāku un informācijas 
faktors (kā vecāki sagatavoja bērnu pirms zobārsta apmeklējuma, kur ieguva informāciju par bērna sagatavošanu un zobu kopšanu, kas pavadīja bērnu pie zobārsta), zobu kopšanas paradumi un attieksme (cik regulāri tika tīrīti zobi, kāda bija bērna attieksme pret zobu kopšanu, fluorīdu lietošana), bērna rakstura iezīmes (personība) un uzvedība (bērna sabiedriskums, aktivitāte, emocionalitāte, kautrīgums, impulsivitāte, labilitāte, vispārējā trauksme, spēja pašam nomierināties, bērna bailes no citām lietām un/vai parādībām, bērna baiļu skaits), kā arī ğimenes stresa faktori (stress vecāku personīgajā dzīiēe (jūtamas dzīves apstākļu izmaiņas, nopietna slimība, tuva cilvēka nāve vai attiecību izjukšana, nepatikšanas ar varas iestādēm, miega traucējumi), stress ǵimenē (kāda ǵimenes locekḷa nāve, šķiršanās, jauna cilvēka ienākšana ǵimenē, nopietni strīdi) un stress saistībā ar darbu (aiziešana no darba vai atlaišana, darbavietas vai pienākumu maiņa, pārmaiņas darba mikroklimatā, konflikts ar priekšniecību).

Bērna zobu stāvoklis tika noteikts ar vizuāli taktilo metodi zobārstniecības krēsla apgaismojumā un ar BW rentgenogrammu palīdzību. Zobu stāvoklis tika novērtēts ar burtiem: A - intakts piena zobs, B - kariozs piena zobs, C - plombēts piena zobs, D - neizšķ̄ilies pastāvīgais zobs, E - ekstrahēts pastāvīgais zobs, P - izšḳ̄lies pastāvīgais zobs. Savukārt zoba bojājuma pakāpe tika noteikta atbilstoši ICDAS (angliski - International Caries Detection and Assessment index, Ismail et al., 2007) kritērijiem (0 - intakts zobs, 2 - emaljas kariess, 3 - dentīna kariess, 4 - kariess ar pulpas iesaistī̌sanos, 5 - plombēts ar primāru kariesu, 6 - plombēts ar sekundāru kariesu, 7 - plombēts, 8 - izslēgtas virsmas, 9 - silants vai laka). Pēc vizītes tika aprēķināts kariozo, plombēto un ekstrahēto zobu un virsmu skaits (atsevišksi piena (kp) un pastāvīgajiem zobiem (KPE), kā arī abu rādītāju summa (KPE + kp)). Emaljas kariesa skartie zobi un virsmas tika ieskaitītas kā intaktas, nevis kariozas.

Bērna uzvedība zobārsta kabinetā tika novērtēta pēc Frankla skalas (1 - izteikti negatīva, 2 - drīzāk negatīva, 3 - drīzāk pozitīva, 4 - izteikti pozitīva) (Frankl et al., 1962).

\subsection{Pētījuma statistiskās metodes}

Gan Modificētajai zobārstniecības trauksmes skalai (MDAS), gan Bērna baiļu pārskata zobārstniecības skalai (CFSS-DS) tika aprēķināta aprakstošā statistika (vidējā aritmētiskā vērtība, standartnovirze, minimālā un maksimālā vērtība) katram jautājumam un jautājumu summai. Tika aprēķināta aprakstošā statistika arī katra bērna mutes dobuma veselību raksturojošiem rādītājiem (kp, KPE, KPE + kp). Anketām tika aprēķināta ticamība (Kronbaha alfa), bet CFSS-DS - pārbaudīta konverǵentā validitāte, aprēķinot Pīrsona korelāciju starp 
pantu summu un aptaujas pirmo jautājumu (bailes no zobārsta), kā arī korelāciju ar bērna uzvedību (Frankla skalā).

Lai pārbaudītu bērnu un vecāku baiḷu no zobārsta, bērnu vecuma, bērna uzvedības zobārsta kabinetā, kā arī kariozo, plombēto un ekstrahēto zobu un virsmu skaita saistību, tika veikta Pīrsona korelāciju analīze. Atkarībā no korelācijas koeficienta vērtības, korelācija tika novērtēts kā cieša (ja $r \geq 0,7)$, vidēja $(0,3<r<0,7)$ vai vāja (ja $r \leq 0,3)$. Bērnu baiḷu no zobārsta dzimuma atšķirības tika pārbaudītas ar Stjūdenta t-testu analīzi. Lai pārbaudītu sakarību starp bērna bailēm no zobārsta un veidu, kādā bērni tika sagatavoti pirms zobārsta apmeklējuma, tika veikta ANCOVA analīze (bērna vecums tika kontrolēts). Rezultātus novērtēja kā statistiski ticami atšķirīgus, ja nulles hipotēzes varbūtība (p) bija vienāda ar 0,05 vai mazāka par to.

Visbeidzot, lai noteiktu, kādi faktori bija noteicošie bērnu baiḷu no zobārsta attīstībā, tika veikta Pīrsona korelācija un sekojoša vairāksoḷu (angliski - stepwise) lineārā regresija ar neatkarīgiem mainīgajiem psihosociālo faktoru bloka ietvaros. Konkrētā psihosociālo faktoru bloka vairāksoḷu lineārās regresijas analīzē pirmajā solī tika iekḷauts bērna vecums un KPE, lai kontrolētu pārējos main̄̄gos, bet tālāk tika iekḷauti visi neatkarīgie mainīgie, kuri ar BTZ korelēja ar ticamības līmeni $\mathrm{p}<0,1$. Šāds, nevis ierastais $(\mathrm{p}<0,05)$ neatkarīgo mainīgo korelācijas ticamības līmenis tika izvēlēts, jo main̄̄gie ar šādu ticamības līmeni varētu parādīties kā nozīmīgi neatkarīgie mainīgie, kas ticami izskaidro bailes no zobārsta. Katrā lineārās regresijas solī tika pievienots pa vienam statistiski nozīmīgam neatkarīgajam mainīgajam, līdz tika sasniegts (fiksēts) tas solis, kurā bija maksimāli daudz neatkarīgo main̄̄go, kas izskaidroja atkarīgo main̄̄go (bailes no zobārsta) statistiski ticamā līmen̄̄, veidojot noteiktu modeli. Soḷa numurs (piemēram, 4.solis) raksturoja atkarīgo mainīgo skaitu (piemēram, 4) šajā modelī. Koeficients $\mathrm{R}^{2}$ raksturoja, cik lielā mērā (procentuāli) iegūtais modelis jeb main̄̄go kopums izskaidroja baiḷu no zobārsta variāciju. Statistiskā analīze tika veikta ar SPSS 22.0 versiju. 


\section{REZULTĀTI}

\subsection{Anketu aprakstošās statistikas rezultāti}

Šajā nodaḷā sniegti visu main̄̄go lielumu aprakstošās statistikas rezultāti anketu jautājumu secībā, savukārt 3.2. nodaḷā seko main̄̄go secinošās statistikas rezultāti.

\subsubsection{Bērnu baiḷu pārskata zobārstniecības skala (CFSS-DS), ticamība un validitāte}

Vidējais bērnu baiḷu no zobārsta līmenis bija $M=32,45$ ( $S D=10,97$, min. - 15, maks. - 70). Salīdzinot atsevišşus faktorus Bērnu baiļu pārskata zobārstniecības skalā, visvairāk bērni baidījās no injekcijām, kad zobārsts urbj un no iešanas slimnīcā (skat. 3.1. tabulu). Savukārt vismazāk bērni baidījās no cilvēkiem baltos halātos, kad jāatver mute un kad zobārsts vai higiēnists tīra zobus (skat. 3.1. tabulu).

3.1. tabula

Bērnu baiḷu pārskata zobārstniecības skalas (CFSS-DS) rezultāti atsevišķiem pantiem un summai

\begin{tabular}{|c|c|c|c|c|c|}
\hline $\begin{array}{l}\text { Panta } \\
\text { nr. }\end{array}$ & Cik lielā mērā Jūsu bērns baidās... & Min. & Maks. & $M$ & $S D$ \\
\hline 1. & ..no zobārstiem & 1 & 5 & 2,46 & 1,32 \\
\hline 2. & ..no ārstiem & 1 & 5 & 1,92 & 0,88 \\
\hline 3. & ..no injekcijām (špricēm) & 1 & 5 & 3,17 & 1,28 \\
\hline 4. & ..kad pārbauda viņa/viņas muti & 1 & 5 & 1,84 & 1,02 \\
\hline 5. & ..kad viņam/viņai jāatver mute & 1 & 5 & 1,68 & 1,01 \\
\hline 6. & ..kad nepazīstams cilvēks pieskaras viņam/viņai & 1 & 5 & 1,98 & 0,89 \\
\hline 7. & ..kad kāds pētoši skatās uz viṇu (novēro) & 1 & 5 & 1,80 & 0,89 \\
\hline 8. & ..kad zobārsts urbj & 1 & 5 & 2,85 & 1,36 \\
\hline 9. & ..no skata, kad zobārsts urbj & 1 & 5 & 2,04 & 1,14 \\
\hline 10. & .no zobu urbšanas trokšņa,skaņas & 1 & 5 & 2,10 & 1,19 \\
\hline 11. & ..kad viņam/viņai liek mutē instrumentus & 1 & 5 & 2,32 & 1,16 \\
\hline 12. & ..no smakšanas vai aizrīšanās & 1 & 5 & 2,45 & 1,31 \\
\hline 13. & ..kad jāiet slimnīcā & 1 & 5 & 2,64 & 1,28 \\
\hline 14. & ..no cilvēkiem baltos halātos & 1 & 5 & 1,44 & 0,81 \\
\hline \multirow[t]{2}{*}{15.} & ..kad zobārsts vai higiēnists tīra viṇa/viņas zobus & 1 & 5 & 1,75 & 0,99 \\
\hline & Kopā: & 15 & 70 & 32,45 & 10,97 \\
\hline
\end{tabular}

Visaugstākais vidējais bērnu baiļu līmenis bija 4 gadu vecumā (skat. 3.1. attēlu), savukārt viszemākais - 12 gadu vecumā. Tomēr baiḷu līmeņa samazināšanās nenotika lineāri, jo sešgadniekiem bija trešais zemākais baiḷu līmenis, savukārt vienpadsmit gadus veciem bērniem - viens no augstākajiem baiļu no zobārsta līmeņiem. Bērnu baiḷu no zobārsta dzimuma un vecuma atškirīības sīkāk analizētas 4.2.1. nodaḷā. 


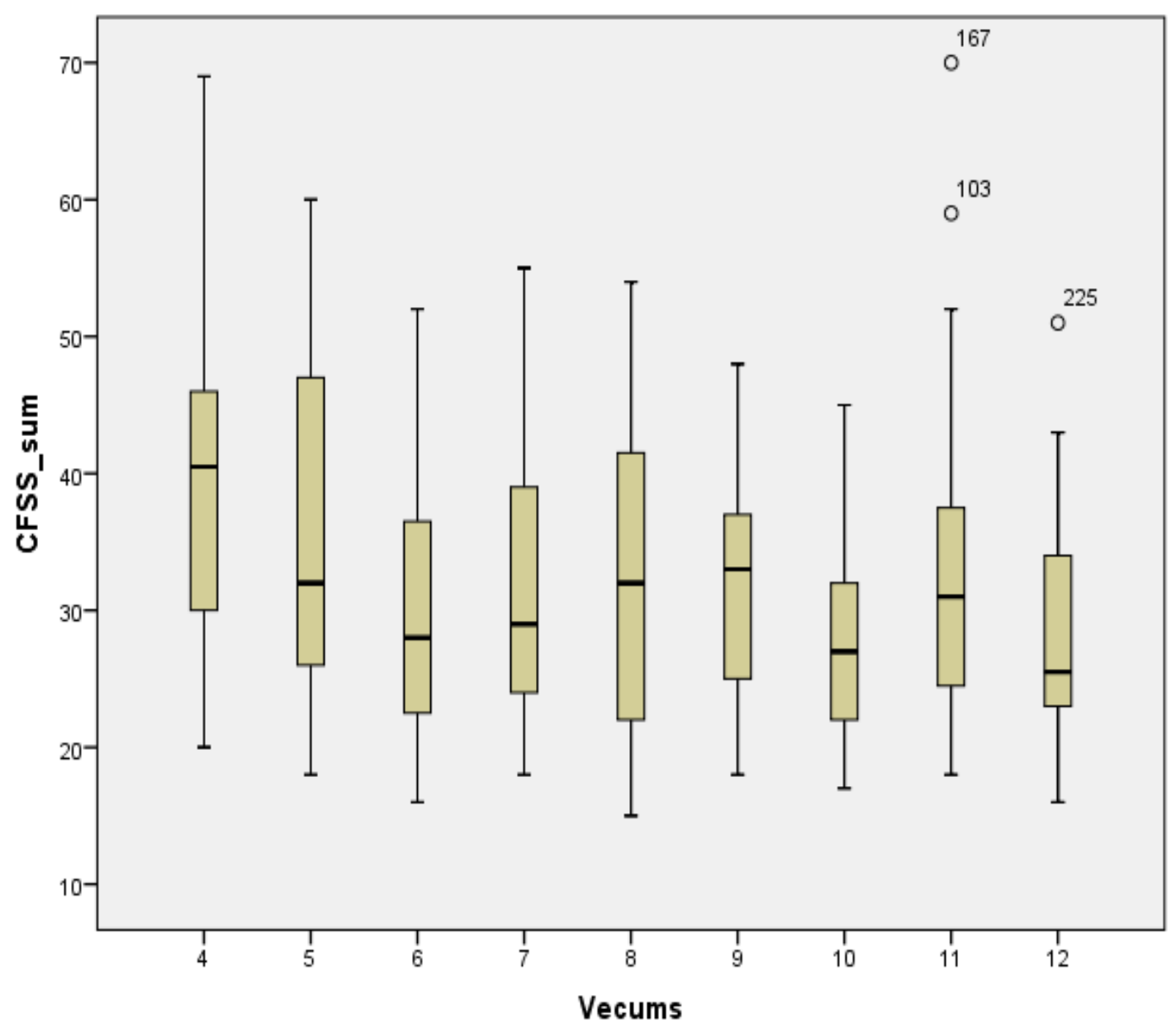

3.1. attēls. Bērnu baiḷu pārskata zobārstniecības skalas (CFSS-DS) vidējie rezultāti pēc bērna vecuma (gados) ar ticamības intervālu

CFSS-DS aptaujas Kronbaha alfa jeb ticamība bija 0,91 (augsta). CFSS-DS bija pietiekami augsta konverǵentā validitāte - aptaujas 1.jautājuma (cik lielā mērā Jūsu bērns baidās no zobārstiem) Pīrsona korelācija ar pārējo 14 jautājumu summu bija $r=0,71$ ( $\mathrm{p}<0,001)$, savukārt saistība ar bērna uzvedību $\mathrm{r}=-0,69(\mathrm{p}<0,001)$.

\subsubsection{Modificētā zobārstniecības trauksmes skala (MDAS)}

Vidējais vecāku baiḷu no zobārsta līmenis bija $M=9,81(S D=3,51$, min. -5 , maks. - 23). Vislielākās bailes respondenti atzīmēja, atbildot uz jautājumu, kā jūtas, kad zobārsts gatavojas urbt (skat. 3.2. tabula), savukārt viszemākās atbildes - kā jūtas, ja rītdien jādodas pie zobārsta. Atšķirības starp baiḷu līmeni vīriešiem un sievietēm nebija iespējams noteikt, jo aptaujā nebija lūgts norādīt respondentu dzimumu. 
3.2. tabula

Modificētās zobārstniecības trauksmes skalas (MDAS) rezultāti atsevišķiem pantiem un summai

\begin{tabular}{|c|c|c|c|c|c|}
\hline N.p.k. & Kā Jūs jūtaties... & Min. & Maks. & $M$ & $S D$ \\
\hline 1. & $\begin{array}{l}\text {...ja Jums nākošajā dienā būtu jāiet pie } \\
\text { zobārsta? }\end{array}$ & 1 & 5 & 1,74 & 0,84 \\
\hline 2. & $\begin{array}{l}\text {...kad Jūs gaidāt savu kārtu pie zobārsta } \\
\text { uzgaidāmajā telpā? }\end{array}$ & 1 & 5 & 1,88 & 0,87 \\
\hline 3. & $\begin{array}{l}\text {...sēžot krēslā un gaidot, kamēr zobārsts } \\
\text { sagatavos injekciju? }\end{array}$ & 1 & 5 & 2,20 & 0,94 \\
\hline 4. & $\begin{array}{l}\text {...sēžot zobārsta krēslā un gaidot, kad } \\
\text { zobārsts sāks urbt? }\end{array}$ & 1 & 5 & 2,29 & 0,93 \\
\hline \multirow[t]{2}{*}{5.} & $\begin{array}{l}\text {... kad zobu higiēnists izṇem instrumentus, } \\
\text { lai notīīitu zobus ap smaganām? }\end{array}$ & 1 & 5 & 1,71 & 0,88 \\
\hline & Kopā: & 5 & 23 & 9,81 & 3,51 \\
\hline
\end{tabular}

\subsubsection{Mutes veselība (KPE un kp)}

Piena sakodiens bija 60 bērniem, pastāvīgais sakodiens - 35 bērniem, savukārt 145 bērniem - maiṇas sakodiens. Vidēji bērniem bija skarti 6,73 zobi $(S D=3,57)$, tai skaitā 4,02 kariozi zobi $(S D=3,32)$ un 3,50 plombēti zobi $(S D=2,79)$. Piena sakodienā skarti bija vidēji 5,33 zobi $(S D=3,57)$, tai skaitā 3,30 bija kariozi $(S D=3,30)$, bet 2,68 bija plombēti $(S D=2,41)$ zobi. Pastāvīgajiem zobiem vidēji bija skarti 2,91 zobi $(S D=3,12)$, kariozo un plombēto zobu skaits bija līdzīgs - attiecīgi 1,60 (SD = 2,06) un 1,61 $(S D=2,23)$ zobi (skat. 3.3. tabulu). Četriem bērniem bija intakts sakodiens, tai skaitā, vienam bērnam - piena sakodienā, trijiem - maiņas sakodienā. Četriem bērniem kopumā 11 zobos bija aplicēti silanti.

\begin{tabular}{|c|c|c|c|c|c|c|}
\hline Zobu veselības rādītāji: & Resp. skaits (n) & Zobu skaits & Min. & Maks. & $M$ & $S D$ \\
\hline Kopējais KPE (KPE + kp) & 240 & 1615 & 0 & 20 & 6,73 & 3,57 \\
\hline Past.zobiem (KPE) & 180 & 524 & 0 & 18 & 2,91 & 3,12 \\
\hline Piena zobiem (kp) & 205 & 1092 & 0 & 20 & 5,33 & 3,57 \\
\hline Kopā kariozi zobi (K + k) & 240 & 966 & 0 & 20 & 4,02 & 3,32 \\
\hline Past.zobiem (K) & 180 & 288 & 0 & 13 & 1,60 & 2,06 \\
\hline Piena zobiem (k) & 205 & 676 & 0 & 20 & 3,30 & 3,30 \\
\hline Kopā plombēti zobi (P + p) & 240 & 839 & 0 & 14 & 3,50 & 2,79 \\
\hline Past.zobiem (P) & 180 & 289 & 0 & 14 & 1,61 & 2,23 \\
\hline Piena zobiem (p) & 205 & 550 & 0 & 11 & 2,68 & 2,41 \\
\hline Kopā ekstrahēti zobi (E) & 180 & 10 & 0 & 3 & 0,06 & 0,31 \\
\hline
\end{tabular}

Visaugstākā kariesa intensitāte (KPE + kp) bērniem ir 4 gadu vecumā, savukārt viszemākā - 7 un 12 gadu vecumā, kad, iespējams, zaudēti kariozie piena zobi un ir nesen izšks̄ilušies pastāvīgie zobi (skat. 3.2. attēlu). 


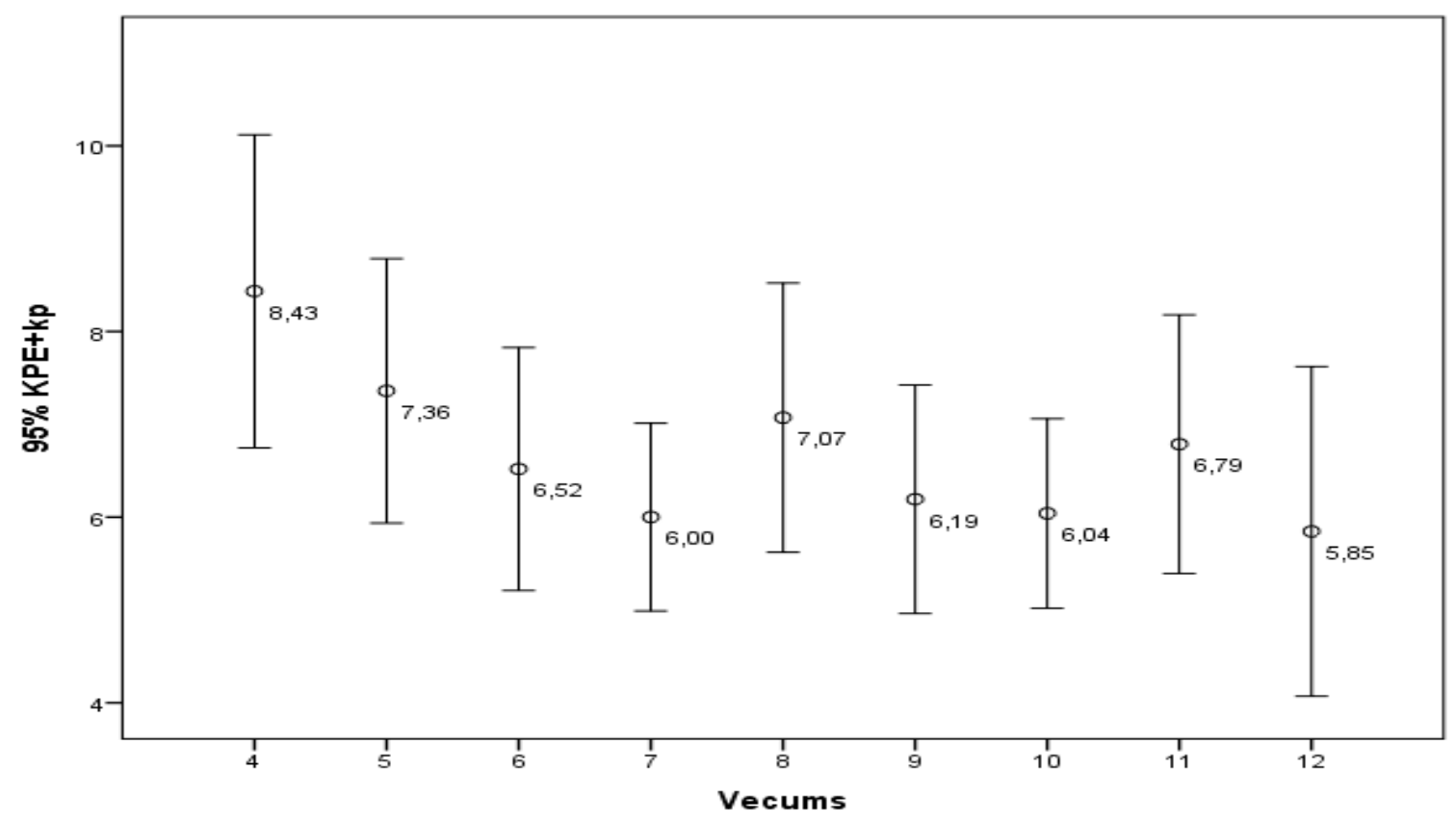

3.2.attēls. Kopējais skarto zobu vidējais skaits (KPE + kp) pēc bērna vecuma (gados) ar ticamības intervāliem

\subsubsection{Bērna uzvedība zobārsta kabinetā}

Vidējais rādītājs bērna uzvedībai zobārsta krēslā Frankla skalā bija 2,78 $(S D=0,83)$. Visbiežākais vērtējums bērna uzvedībai bija 3 (drīzāk pozitīva) - 53,7\% respondentu ( $\mathrm{n}=129)$, tam sekoja 2 (drīzāk negatīva) - 20,4\% gadījumu $(\mathrm{n}=49)$, tad 4 (izteikti pozitīva) $-16,7 \%$ gadījumu $(\mathrm{n}=40)$, bet vērtējums 1 (izteikti negatīva) $-9,2 \%$ gadījumu $(\mathrm{n}=$ 22). Respondentu sadalījumu pa vecuma grupām skat. 3.4. tabulā. Bērnu uzvedība zobārsta kabinetā statistiski nozīmīgi korelēja ar bērna vecumu $(r=0,354, p<0,001)$, tas nozīmē, jo vecāks bija bērns, jo pozitīvāka bija viņa uzvedība zobārsta krēslā. Zēnu un meiteṇu uzvedības novērtējums neatšķīās statistiski nozīmīgi (attiecīgi $M=2,69(S D=0,822)$ un $M=2,86(S D=0,836), \mathrm{t}=-1,548, \mathrm{p}=0,123)$.

3.4. tabula

Bērna uzvedības zobārsta kabinetā novērtējuma Frankla skalā vidējie rādītāji pēc bērna vecuma gados

\begin{tabular}{|l|c|c|c|}
\hline Vecums & Respondentu skaits (n) & $M$ & $S D$ \\
\hline 4 & 30 & 1,97 & 0,850 \\
\hline 5 & 25 & 2,40 & 1,041 \\
\hline 6 & 27 & 3,15 & 0,818 \\
\hline 7 & 25 & 2,76 & 0,663 \\
\hline 8 & 28 & 2,71 & 0,854 \\
\hline 9 & 26 & 2,88 & 0,516 \\
\hline 10 & 25 & 3,16 & 0,473 \\
\hline 11 & 28 & 2,79 & 0,686 \\
\hline 12 & 26 & 3,31 & 0,549 \\
\hline Kopā: & 240 & 2,78 & 0,832 \\
\hline
\end{tabular}




\subsubsection{Anketa par bērna attieksmi pret zobārstu (dažādi psihosociālie faktori)}

Šajā nodaļā tiks sīkāk raksturoti aprakstošās statistikas rezultāti par dažādiem psihoemocionālajiem faktoriem septiņos blokos - sociālekonomiskais/sociāldemogrāfiskais bloks, bērna medicīniskā pieredzes un attieksmes pret ārstiem bloks, bērna zobārstniecības pieredzes un attieksmes pret zobārstiem bloks, vecāku un informācijas bloks, bērna personības un uzvedības bloks, mutes kopšanas paradumu un attieksmes bloks, kā arī ǵimenes stresa bloks.

\subsubsection{Sociāldemogrāfiskais bloks}

Vidējais ǵimenes locekḷu skaits bija $M=3,86(S D=1,00$, min. -2 , maks. -11 , $n=240)$. Savukārt vidējais mājsaimniecībā dzīvojošo skaits, t.i., ğimenes locekḷu skaits, ieskaitot vecvecākus, bija 4,14 (SD = 1,13, min. - 2, maks. - 12, n = 240$)$. Vidējais bērnu skaits ǵimenē bija 1,99 (SD = 0,85, min. - 1, maks. - 9, $\mathrm{n}=240)$. Uz jautājumu, vai bērns ir adoptēts, atbildes atzīmēja 95,8\% respondentu, tai skaitā 1 respondents - apstiprinoši un norādīja, ka bērns dzīvo ğimenē 12 gadus.

Uz jautājumu par ğimenes stāvokli atbildēja 240 respondenti. Gandrīz 2 trešdaḷas (62,9\% respondentu) norādīja, ka vecāki ir precējušies, 18,9\% respondentu - nav precējušies, bet dzīvo kopā, 16,6\% respondentu - šķīrušies vai dzīvo šķirti, savukārt 1,6\% respondentu norādīja, ka ir atraitņi. Analizējot datus, atsevišķıi tika skatītas grupas, kurās vecāki ir precējušies pret pārējām grupām (,precējušies” pret „,citiem”), kā arī grupas, kurās vecāki dzīvo kopā pret pārējām grupām (,kopā”” pret „citi”).

Vidējais vecums mātēm bija $M=35,04$ ( $S D=8,11$, min. -23 , maks. $-53, \mathrm{n}=233$ ), savukārt vidējais tēvu vecums bija 35,12 (SD = 13,40, min. -26 , maks. $-65, \mathrm{n}=215) . \mathrm{Uz}$ jautājumu par mātes izglītību atbildēja 232 respondenti, savukārt tēva izglītība bija norādīta 215 anketās. Sadalījumu pēc izglītības līmeņa skat. 3.3. un 3.4. attēlā. Analizējot datus, respondenti tika sadalīti 3 grupās: 1 - pamatizglìtība, 2 - vidējā (ieskaitot profesionālo un nepabeigtu augstāko izglītību) un 3 - augstākā izglītība. 


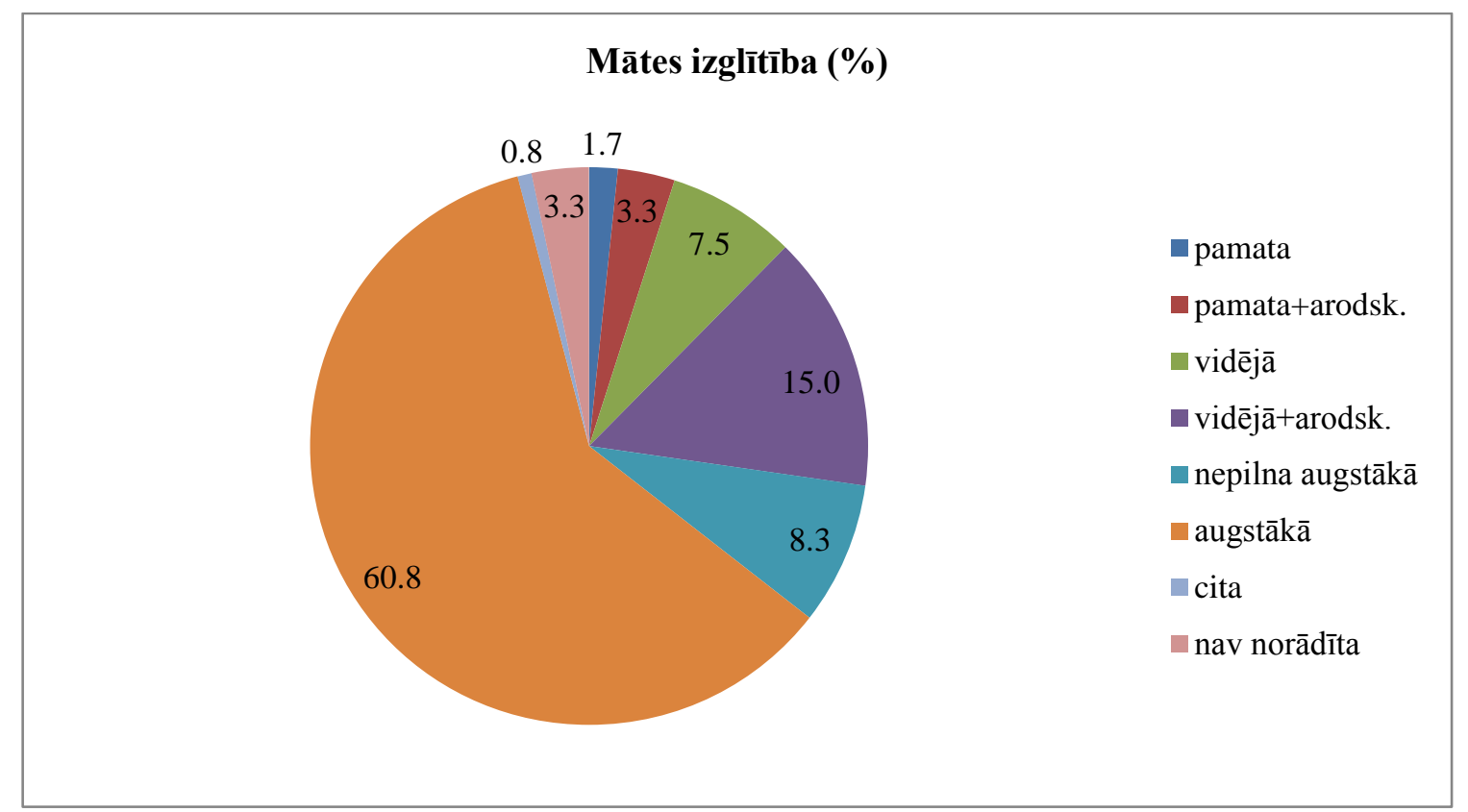

3.3. attēls. Procentuālais sadalījums izglītības līmeņiem mātēm $(\mathbf{n}=\mathbf{2 3 2})$

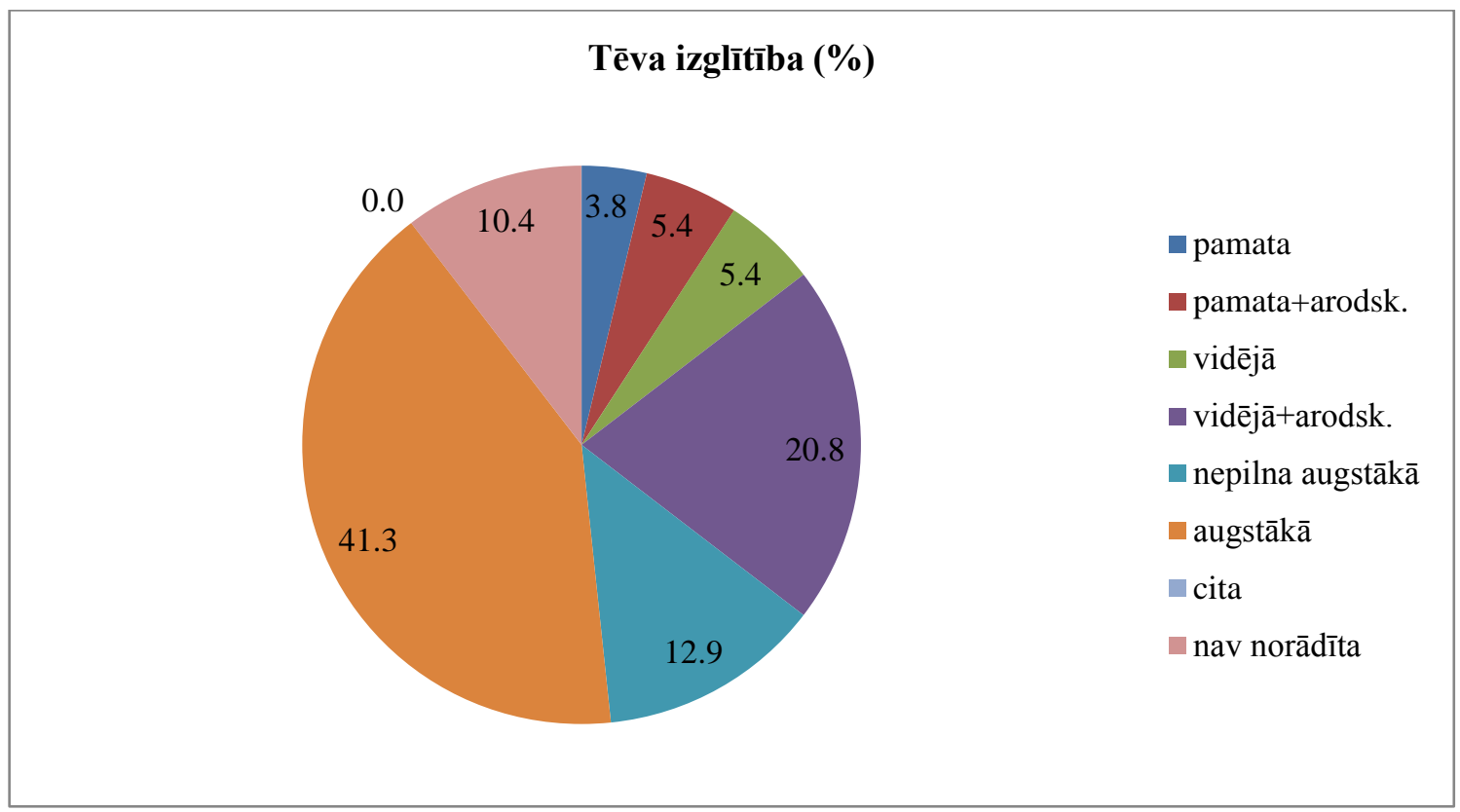

3.4. attēls. Procentuālais sadalījums izglītības līmeņiem tēviem $(\mathbf{n}=\mathbf{2 1 5})$

Mātes darba statuss (nodarbinātība) bija norādīta 214 anketās (180 strādāja algotu darbu, bet 34 - bija bērna kopšanas atvaļinājumā, mājsaimnieces, bezdarbnieces vai studēja). Savukārt tēva nodarbinātības statuss bija norādīts 192 anketās, kurās tikai 2 respondenti nestrādāja algotu darbu.

Ģimenes ienākumu līmeni atzīmēja 232 respondenti. Lielākajai daļai respondentu ienākumi bija no 101 līdz 200 Ls vai no 201 līdz 400 Ls mēnesī uz 1 cilvēku ǵimenē, bet tikai 1\% respondentu atzīmēja ienākumu līmeni līdz 50 Ls mēnesī uz 1 cilvēku (skat. 3.5. tabulā). 
Bērnu vecāku ienākumu līmenis uz 1 cilvēku ğimenē mēnesī

\begin{tabular}{|l|c|c|}
\hline Ienākumu līmenis & Respondentu skaits(n) & Respondenti (\%) \\
\hline Līdz 50 Ls mēnesī uz 1 cilvēku ǵimenē & 4 & 1,7 \\
\hline No 51 līdz 100 Ls mēnesī uz 1 cilvēku ǵimenē & 36 & 15,0 \\
\hline No 101 līdz 200 Ls mēnesī uz 1 cilvēku ğimenē & 76 & 31,7 \\
\hline No 201 līdz 400 Ls mēnesī uz 1 cilvēku ğimenē & 84 & 35,0 \\
\hline Virs 401 Ls mēnesī uz 1 cilvēku ǵimenē & 32 & 13,3 \\
\hline Nav atbildējuši & 8 & 3,3 \\
\hline
\end{tabular}

\subsubsection{Bērna medicīniskās pieredzes un attieksmes bloks}

Hronisku slimību esamību norādīja 38 no 240 respondentiem jeb 15,8\%. Slimības bija no bronhiālās astmas līdz iedzimtam gūžas mežǵījumam. Slimošanas biežums atšksiras dažādiem bērniem, tomēr lielākā daļa bērnu jeb 65\% slimo 2-3 reizes gadā, un 55\% respondentu atzīmē, ka pie ārsta dodas 2-3 reizes gadā (skat. 3.5. un 3.6. attēlā).

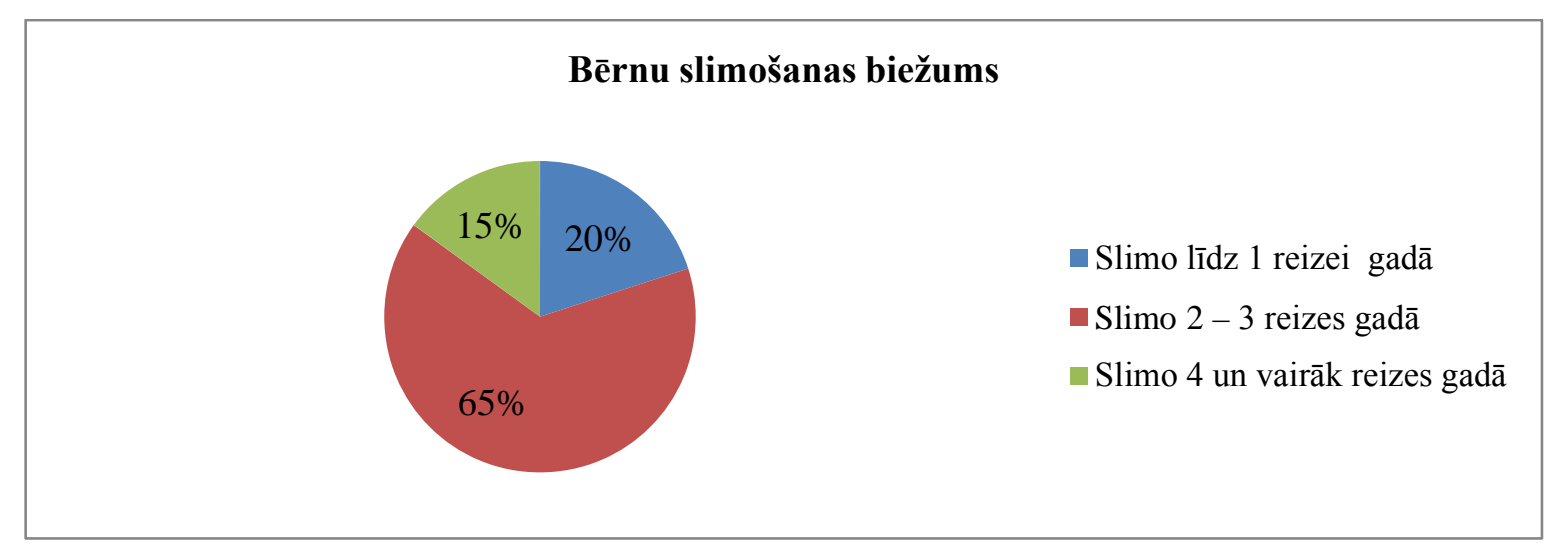

3.5. attēls. Procentuālais sadalījums bērnu slimošanas biežumam gada laikāa

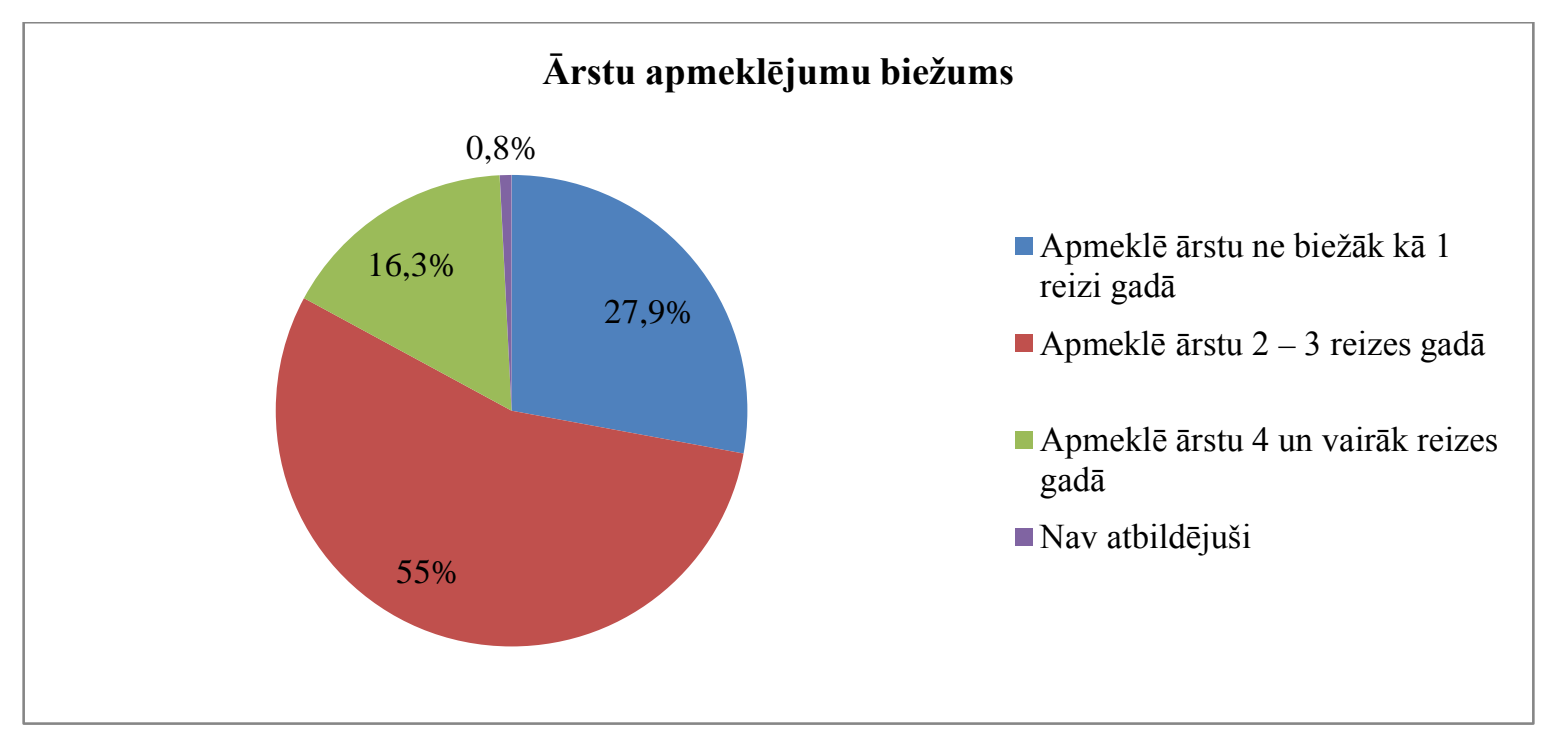

3.6. attēls. Procentuālais sadalījums ārstu apmeklējumu biežumam gada laikā 
Līdzīga daļa respondentu jeb, attiecīgi, 33,8\%, 27,1\% un 32,9\% norāda, ka bērnam ir draudzīga, neitrāla vai piesardzīga attieksme pret ārstiem, bet 8,8\% respondentu atzīmē bailīgu attieksmi pret ārstiem (izṇemot zobārstus). Viens respondents norāda, ka draudzīga attieksme ir tikai pret pazīstamiem ārstiem, savukārt vēl viens respondents nav atbildējis uz šo jautājumu (skat. 3.7. attēlu.).

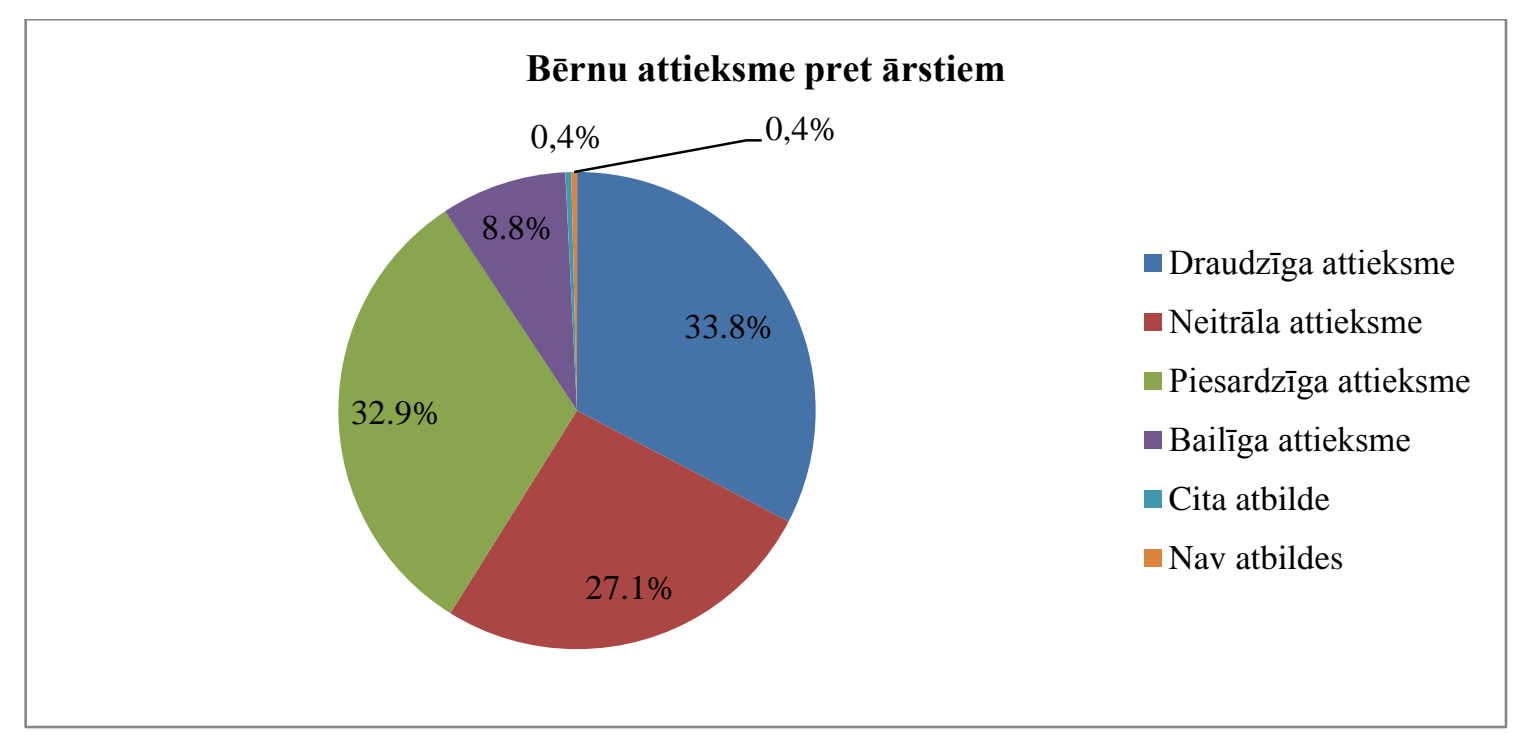

3.7. attēls. Procentuālais sadalījums bērnu attieksmju veidiem pret ārstiem

Traumatisku pieredzi pie ārstiem (izṇemot zobārstus) norāda 19,6\% respondentu, vidēji 1,89 reizes $(S D=2,93$, min. -1 , maks. -20 reizes), vidējais vecums visagrākās traumatiskās pieredzes laikā bija 2,99 gadi $(S D=1,95$, min. vecums - tūlīt pēc dzimšanas, maks. - 8 gadi). Slimnīcā ārstējušies 59,6\% respondentu, vidēji 2,09 reizes $(S D=2,54$, no 1-25 reizēm), vidējais vecums agrākās piedzīvotās hospitalizācijas laikā 3,07 gadi $(S D=2,54$, min. -1 mēneša vecumā, maks. - 11 gadu vecumā). Ārstēšana vispārējā narkozē ir bijusi nepieciešama 29,6\% respondentu, vidēji 1,39 reizes ( $S D=0,75$, no $1-5$ reizèm, vidēji 3,98 gadu vecumā $(S D=2,55$, min. - 1 mēneša vecumā, maks. - 11 gadu vecumā. Savukārt fiziskas traumas, kuru dēḷ bijusi nepieciešama neatliekamā palīdzība, atzīmē 32,1\% respondentu, vidēji 1 , 49 reizes ( $S D=1,40$, no $1-12$ reizēm), pirmās gūtās fiziskās traumas laikā bērna vecums bija vidēji 4,81 gadi $(S D=2,96$, min. - 0 mēneši (dzemdību laikā gūta trauma), maks. -12 gadi).

\subsubsection{Zobārstniecības pieredzes un attieksmes bloks}

Vairāk nekā puse respondentu $(55,4 \%)$ kā iemeslu pirmajai vizītei pie zobārsta norādījuši „lai iepazītu zobārsta kabinetu, pārbaudītu zobus”. Daudz mazāk respondenti 
atzīmējuši atbildes „,ievēroja izmaiņas bērna zobos” (22,5\%) un „zobu sāpju dēḷ” (18,8\%). Tikai nedaudzus respondentus pie zobārsta nosūtīja kāds cits ārsts (7,9\%) vai citu iemeslu dēl (6,7\%), piemēram, „līdzi vecākajam brālim/māsai” vai ,zīme skolai” (skat. 3.8. attēlu.).

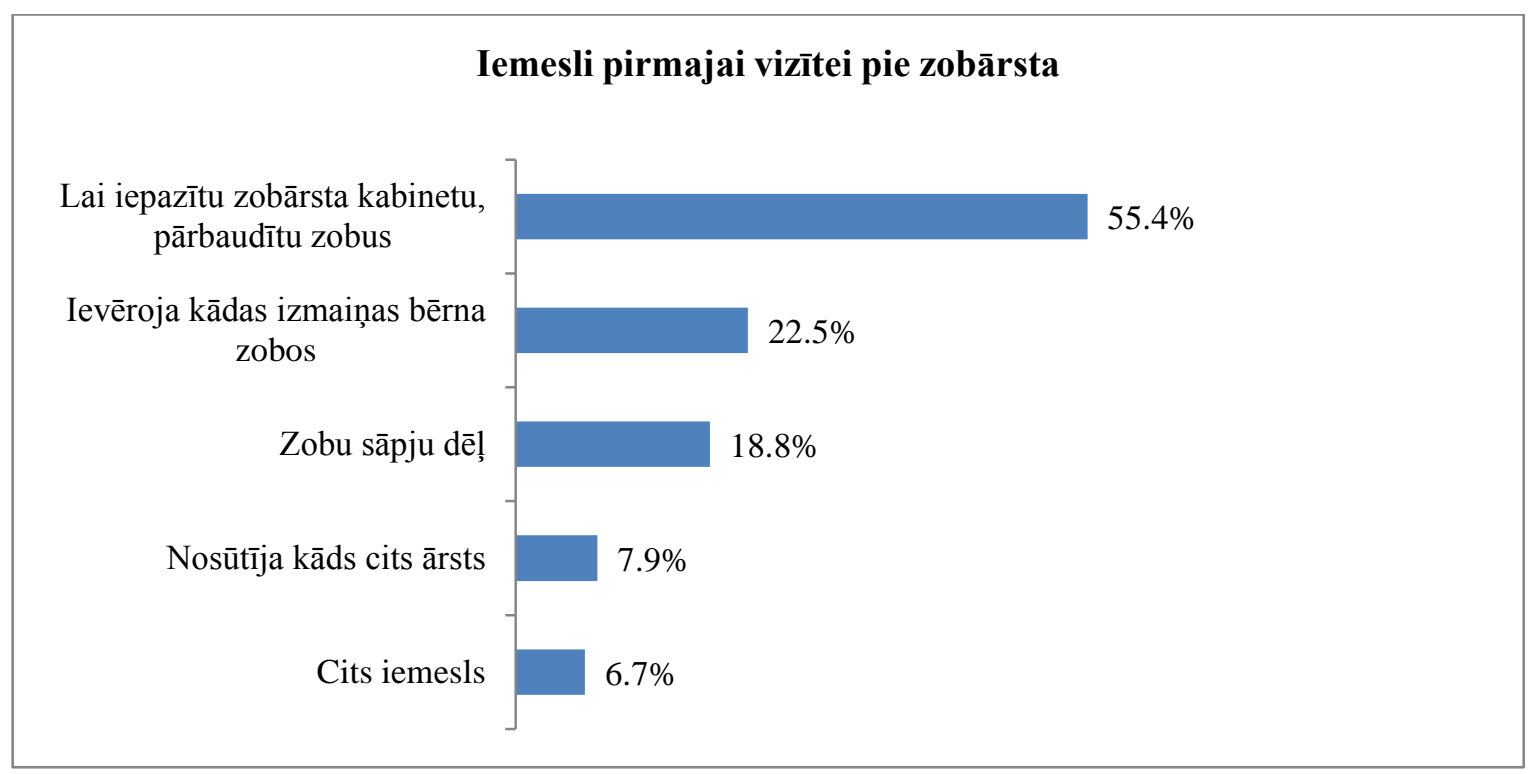

3.8. attēls. Procentuālais sadalījums iemeslu veidiem bērna pirmajai vizītei pie zobārsta

Visvairāk respondentu $(52,1 \%)$ ved bērnu pie zobārsta apmēram 1 reizi gadā. Vairāk nekā trešdaļa bērnu zobārstu apmeklē ik pēc pusgada (35,4\%), bet nedaudz respondentu atzīst, ka apmeklē zobārstu retāk kā 1 reizi gadā (skat. 3.9. attēlu).

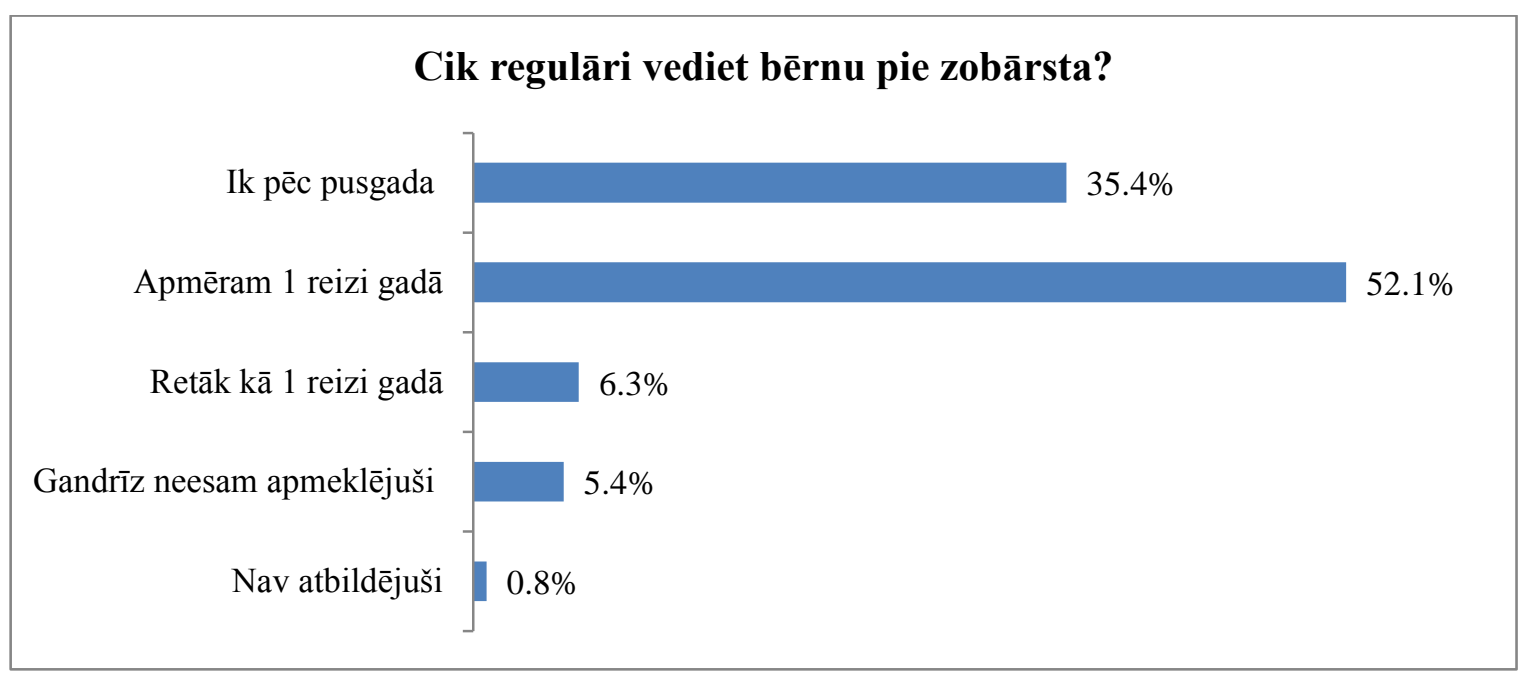

3.9. attēls. Procentuālais sadalījums bērna vizī̌su pie zobārsta regularitātei

Pirmo zobārsta apmeklējumu pēc atmiņas vecāki paši ir norādījuši vidēji 38,87 mēnešu vecumā $(S D=$ 20,13, min. -6 mēneši, maks. -132 mēneši, $\mathrm{n}=235$ (97,9\%)). 
Vizīšu un visagrāk saṇemto procedūru precīzais vecums mēnešos tika atzīmēts tikai respondentiem, kuriem apmeklējuma laiks bija pārbaudāms, piemēram, ar ierakstu kartiņā). Praktiski visi respondenti (99,6\%) bija saņēmuši apskati un/vai konsultāciju vidēji 36,38 $(S D=18,72)$ mēnešu, t.i., aptuveni trīs gadu vecumā (vecums precizēts 58,7\% bērnu). Zobu higiēnu bija saņēmuši 81,7\% respondentu, vidēji 60,68 $(S D=29,01)$ mēnešu jeb aptuveni 5 gadu vecumā (47,5\%) Plombēšana bez vietējās anestēzijas bija veikta 35\% bērnu, vidēji $55,22(S D=20,32)$ mēnešu jeb 4,5 gadu vecumā $(17,2 \%)$. Plombēšana vietējā anestēzijā veikta $86,3 \%$ respondentu vidēji $66,30(S D=22,76)$ mēnešu jeb 5,5 gadu vecumā $(51,7 \%)$. Procedūras vispārējā anestēzijā veiktas agrīnākā vecumā - plombēšana vidēji 51,25 $(S D=17,31)$ mēnešu jeb 4,3 gadu vecumā un ekstrakcijas - vidēji 59,82 $(S D=23,12)$ mēnešu jeb gandrīz 5 gadu vecumā attiecīgi 14,2\% (13,3\%) un 9,6\% (7,1\%) respondentu. Ekstrakcijas bez anestēzijas veiktas 7,5\% (5,4\%) respondentu vidēji 67,08 $(S D=20,99)$ mēnešu jeb 5,5 gadu vecumā. Citu ārstēšanu saņēmuši 6,3\% (2,5\%) bērnu vidēji apmēram 58,83 (SD = 40,76) mēnešu jeb nepilnu piecu gadu vecumā. Pārsvarā norādītas bija mēles vai lūpas saitītes operācijas vai ortodonta konsultācijas (skat. 3.6. tabulu).

3.6. tabula

Bērna vidējais vecums (mēnešos), kurā zobu ārstēšanas veids veikts pirmo reizi (aprakstošās statistikas rādītāji)

\begin{tabular}{|l|r|r|r|r|r|c|}
\hline Saņemtā ārstēšana & \multicolumn{1}{|c|}{$\mathrm{n}_{1}{ }^{*}$} & $\mathrm{n}_{2}{ }^{* *}$ & $M$ & \multicolumn{1}{c|}{$S D$} & Min. & Maks. \\
\hline Apskate, konsultācija & 239 & 141 & 36,38 & 18,72 & 0 & 97 \\
\hline Zobu higiēna & 196 & 114 & 60,68 & 29,01 & 6 & 150 \\
\hline Plombēšana bez anestēzijas & 84 & 41 & 55,22 & 20,32 & 19 & 115 \\
\hline Plombēšana ar vietējo anestēziju & 207 & 124 & 66,30 & 22,76 & 28 & 150 \\
\hline Plombēšana vispārējā anestēzijā & 34 & 32 & 51,25 & 17,31 & 23 & 99 \\
\hline Ekstrakcija vietējā anestēzijā & 129 & 73 & 75,47 & 23,34 & 22 & 131 \\
\hline Ekstrakcija vispārējā anestēzijā & 23 & 17 & 59,82 & 23,12 & 27 & 110 \\
\hline Ekstrakcija bez anestēzijas & 18 & 13 & 67,08 & 20,99 & 5 & 84 \\
\hline Cita ārstēšana & 15 & 6 & 58,83 & 40,76 & 1 & 106 \\
\hline Jebkāda ārstēšana bez visp.anest. & 136 & 136 & 63,29 & 22,82 & 19 & 150 \\
\hline
\end{tabular}

* $\mathrm{n}_{1}$ - respondentu skaits, kuri atzīmējuši, ka bērnam ir veikta norādītā zobu ārstēšana.

${ }^{* *} \mathrm{n}_{2}-$ respondentu skaits, kuriem varēja precizēt bērnam veiktās zobu ārstēšanas laiku līdz vecumam mēnešos.

Zobārsta veiktās procedūras līdz aptaujas brīdim lielākajai daḷai respondentu noritējušas vienmēr bez grūtībām $(27,1 \%)$ vai pārsvarā bez grūtībām $(32,5 \%)$. Savukārt zobu ārstēšanas procesa norise vienmēr ar lielām grūtībām vai gandrīz vienmēr ar lielām grūtībām bijusi attiecīgi 12,1\% un 9,6\% (skat. 3.10. attēlu). 


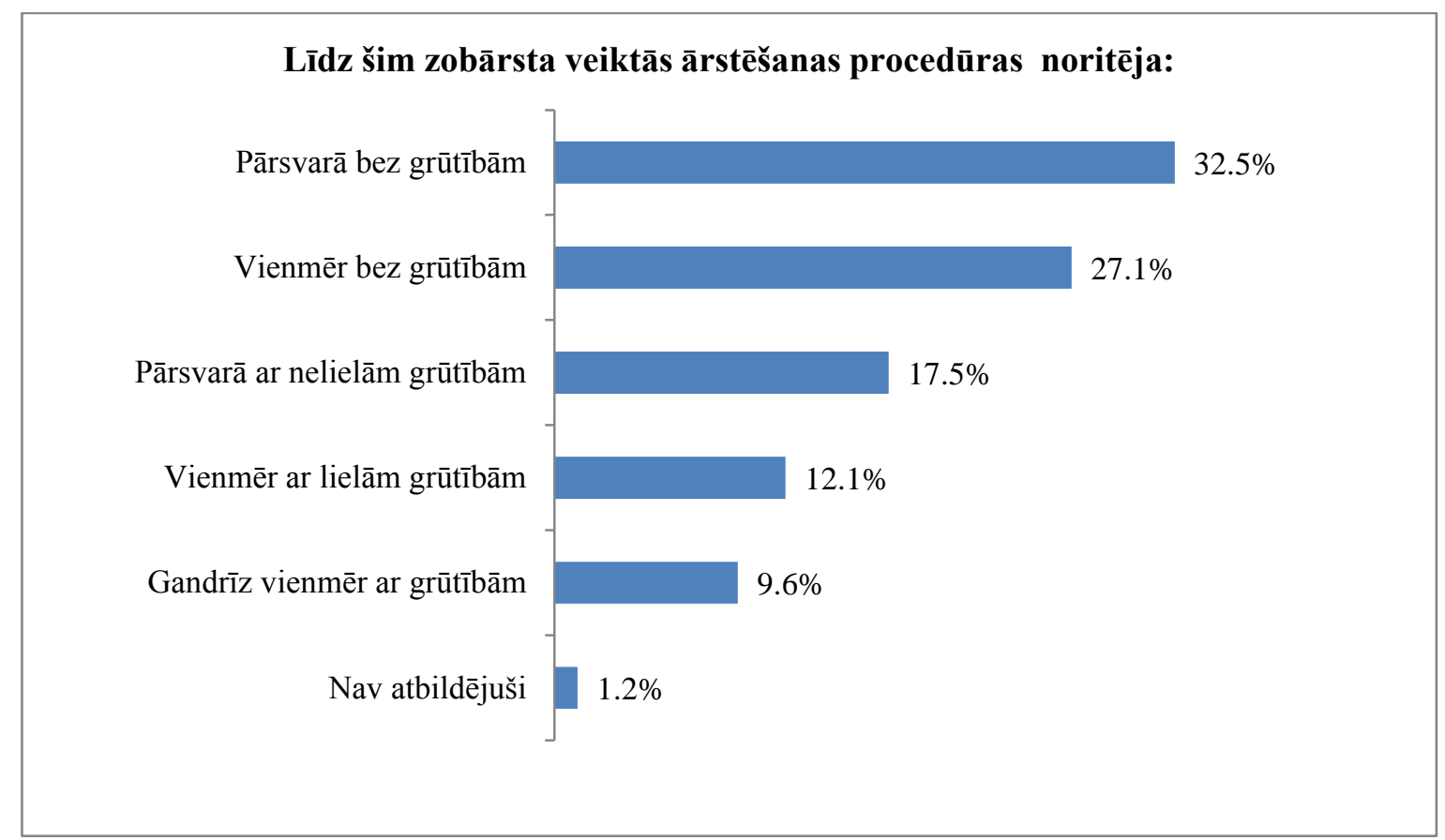

3.10. attēls. Procentuālais sadalījums līdz šim zobārstu veikto ārstēšanas procedūru norises grūtību pakāpēm

Gandrīz puse bērnu (43,8\%), ejot pie zobārsta, izjūt satraukumu un bažas, savukārt neliela daḷa bērnu izrāda aktīvu protestu un pretestību $(5,8 \%)$ vai paniku un histēriju $(4,2 \%)$. Samērā daudziem bērniem $(27,5 \%)$ ir neitrāla, vienaldzīga attieksme pret zobārstu, kā arī prieks un interese (17,5\%) (skat. 3.11. attēlu).

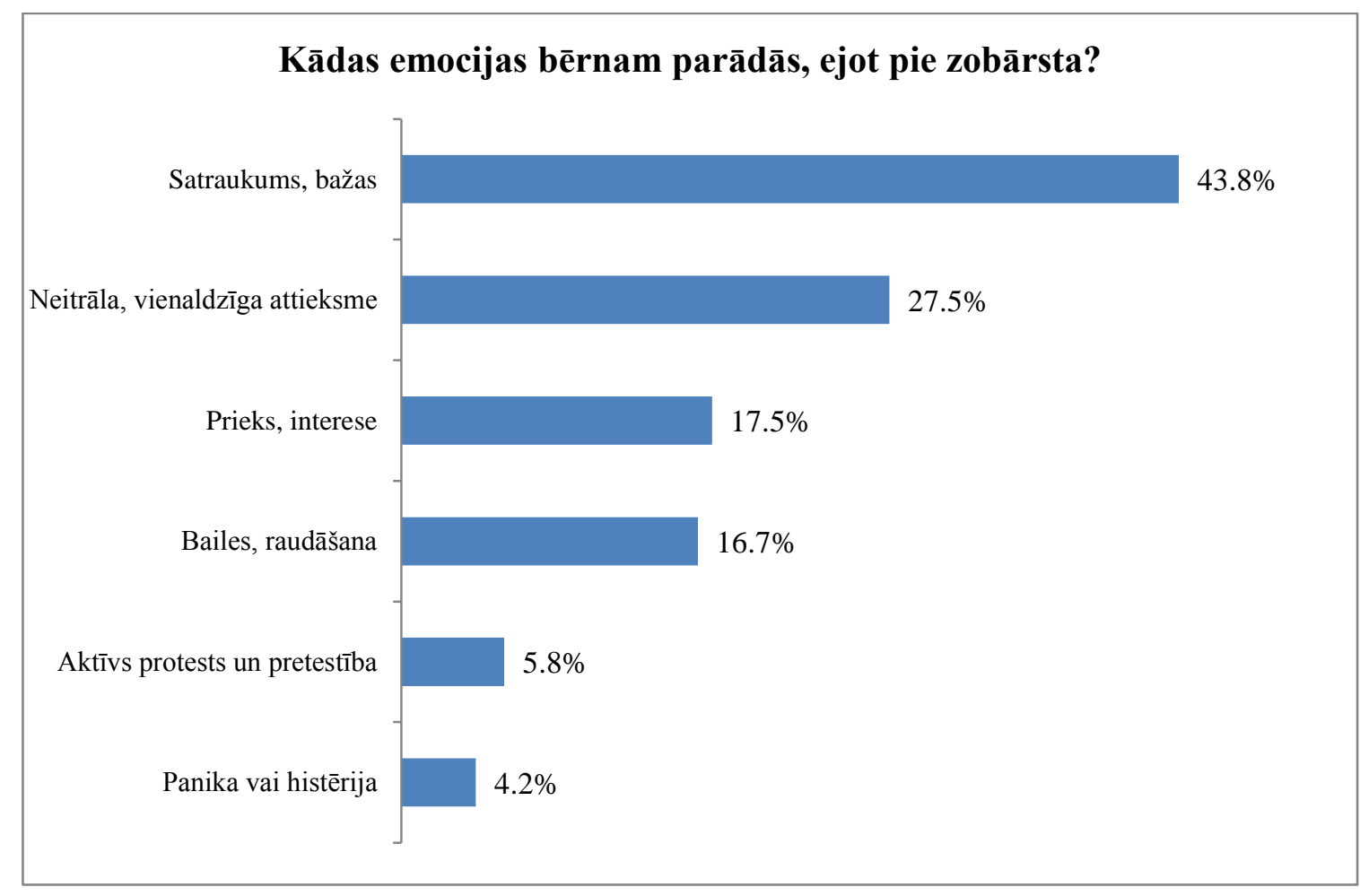

3.11. attēls. Procentuālais sadalījums emociju veidiem, bērnam ejot pie zobārsta 
Negatīva pieredze pie zobārsta ir bijusi apmēram trešdaļai respondentu $(37,9 \%)$, bet lielākajai dą̧ai respondentu $(61,7 \%)$ šādas pieredzes nav bijis, $0,4 \%$ respondentu uz šo jautājumu nav atbildējuši. Absolūtais vairākums respondentu $(73,6 \%)$ negatīvo pieredzi pārvarēja, dodoties pie cita zobārsta vai uz citu klīniku. Samērā daudzi respondenti $(22,0 \%)$ devās vēlreiz pie tā paša zobārsta, 15,4\% devās labot zobus vispārējā narkozēe, bet neliela daḷa respondentu devās pie higiēnista vai nedarīja neko un nogaidīja (attiecīgi, 7,8\% un 7,7\%).

Apmēram puse respondentu (52,7\%) dodas pie zobārsta dažādos laikos, 18,8\% respondentu cenšas iekārtot zobārsta apmeklējumu no rīta, 22,1\% - pēcpusdienā, pēc skolas vai bērnudārza, bet 5,4\% - vakarā, pēc vecāku darba laika.

\subsubsection{Vecāku un informācijas bloks}

Vecāku baiḷu no zobārsta līmenis tika noteikts ar Modificēto Zobārstniecības trauksmes skalu jeb MDAS (skat. 3.1.2. nodaļu).

Visvairāk vecāku pirms zobārsta apmeklējuma bērnam stāsta par savu pieredzi pie zobārsta, mierina, ka nekas nesāpēs un neko nedarīs, vai arī nekā īpaši negatavo. Nedaudz mazāk respondentu sola balvu par labu uzvešanos pie zobārsta, apskata un lasa grāmatas par zobu ārstēšanu vai ņem līdzi bērnu, ejot pie sava zobārsta (skat. 3.12. attēlu). Apmēram septītā daļa respondentu (14,6\%) norādīja citu atbilžu variantu, piemēram, ,pastāstu, ko darīs zobārsts”, „paskaidroju, kāpēc ārstēšana ir nepieciešama” vai „mierinu, ka ārstēšana vajadzīga, lai zobi neizkristu ārā” (skat. 3.12. attēlu).

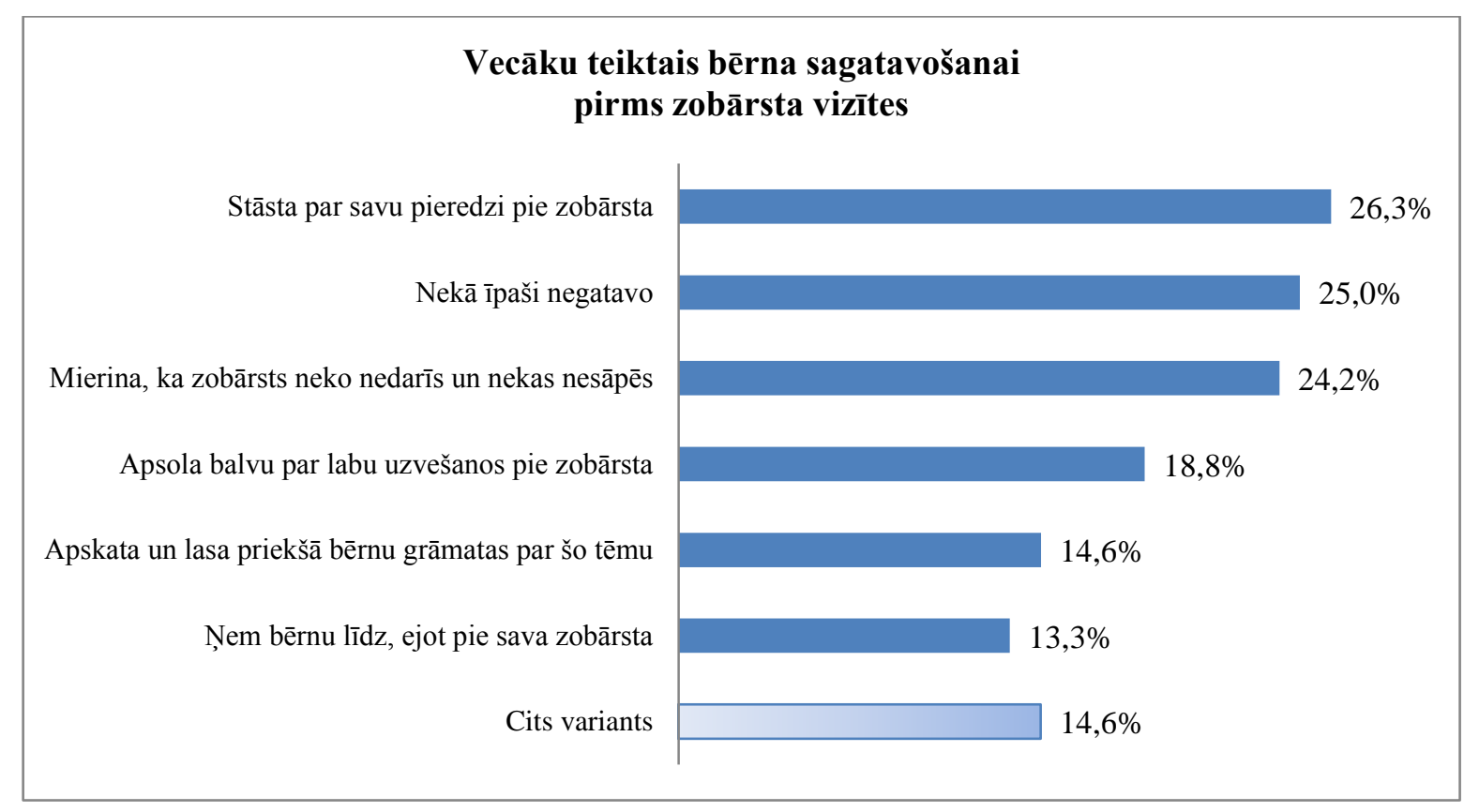

3.12. attēls. Procentuālais sadalījums vecāku teiktā veidiem bērna sagatavošanai zobārsta apmeklējumam (bija iespējama vairāk nekā 1 atbilde) 
Lielākajā daḷā gadījumu bērnus pie zobārsta pavada tikai māte $(38,3 \%)$, tas, kuram ir laiks $(36,3 \%)$ vai jebkurš no pieaugušajiem ǵimenes locekḷiem (19,2\%). Retos gadījumos bērnu pavada tikai tēvs $(4,6 \%)$ vai tas, kuram bērns klausa $(1,7 \%)$. Neviens respondents nav atzīmējis atbilžu variantu „tas, kuram nav bail no zobārsta”.

Informāciju par zobu kopšanu respondenti pārsvarā saņem no zobārsta $(78,3 \%)$ vai zobu higiēnista (47,5\%), arī no plašsaziņas līdzekḷiem (28,3\%). Savukārt informāciju par bērna sagatavošanu zobārsta vizītei lielākā daḷa respondentu nesaņem nekur (41,3\%), saņem no zobārsta $(32,1 \%)$ vai plašsaziṇas līdzekḷiem $(17,9 \%)$ (skat. 3.13. attēlu).

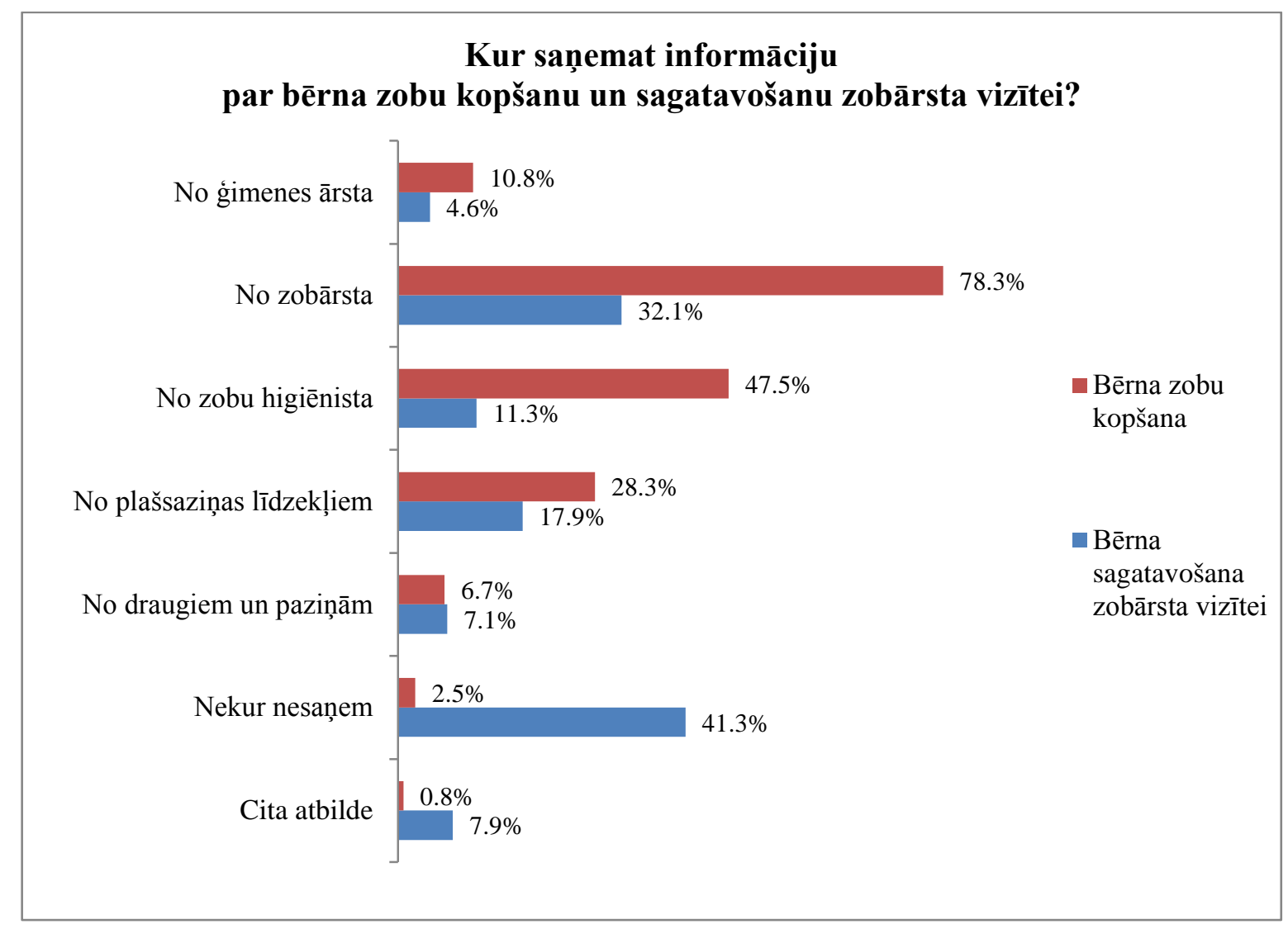

\subsection{3. attēls. Procentuālais sadalījums vecāku informācijas avotiem par bērna zobu kopšanu un bērna sagatavošanu zobārsta apmeklējumam}

Kad bērns ir satraucies vai nobijies, lielākā daļa vecāku bērnu mierina, samīḷojot (72,(\%), pārrunājot sīkāk (62,9\%), pievēršot uzmanību kam citam $(34,6 \%)$ vai sakot, lai neuztraucas $(24,2 \%)$. Arī tad bērns ir bēdīgs, lielākā daļa vecāku mierina bērnu, samīḷojot (75\%), pārrunājot sīkāk (56,3\%), pievēršot uzmanību kam citam $(28,7 \%)$ vai sakot, lai neuztraucas (17,5\%). Kad bērns gatavojas kādam atbildīgam vai satraucošam notikumam, vecāki visbiežāk pārrunā sīkāk gaidāmo notikumu $(66,7 \%)$, iedrošina un uzslavē bērnu $(61,7 \%)$ vai saka, lai neuztraucas $(27,5 \%)$. 
Daļa $(27,1 \%)$ respondentu atzīmē, ka ir pārrunājuši savu personīgo negatīvo pieredzi pie zobārsta bērnu klātbūtnē, bet tikai 5,8\% atzīst, ka baida bērnu ar zobārstu un izmanto to kā soda metodi. Nedaudz $(9,2 \%)$ respondentu ir atlikuši zobārsta apmeklējumu kādu nebūtisku iemeslu dēl, piemēram, nolemjot doties kur citur vai darīt ko citu.

\subsubsection{Zobu kopšanas paradumu un attieksmes bloks}

Lielākā daļa respondentu zobus tīra katru dienu, vienu vai divas reizes (skat. 3.14. attēlu). Retāk nekā vienu reizi dienā, bet vairākas reizes nedēḷā tīra 13,8\% respondentu, bet tikai vairākas reizes mēnesī tīra $0,8 \%$ aptaujāto.

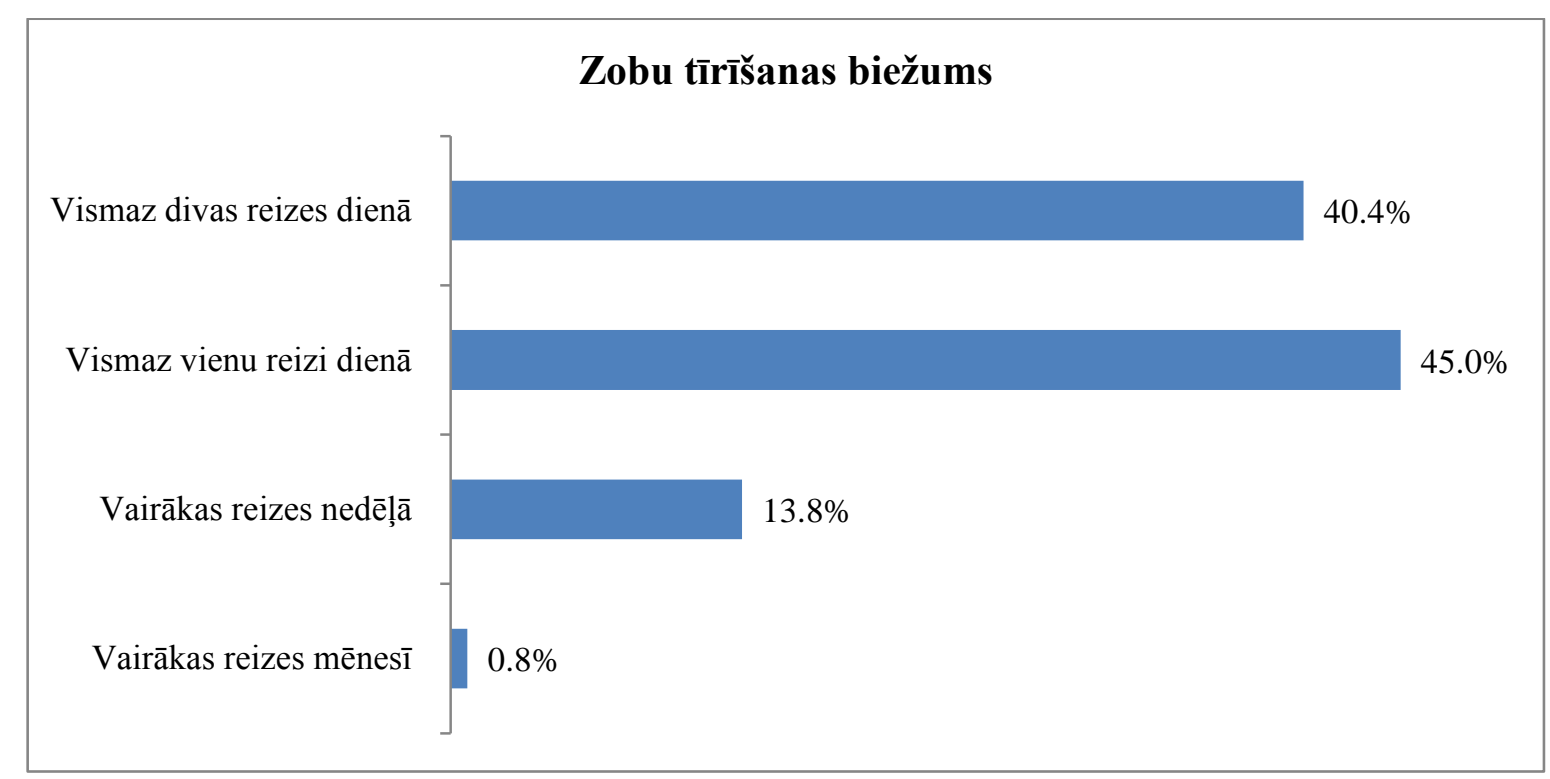

3.14. attēls. Procentuālais sadalījums bērnu zobu tīrīšanas biežumam (regularitātei).

Tikai 44,2\% respondentu atzīst, ka pārbauda bērna zobus pēc tīrǐšanas, bet lielākā daļa - 51,7\% respondentu atzīst, ka nepārbauda bērna zobus pēc tīrīšanas. Daži respondenti $(4,1 \%)$ nav atbildējuši uz šo jautājumu vai atzīmē, ka pārbauda bērnu zobu tīrīšanu dažreiz.

Gandrīz puse respondentu uztver zobu tīrīšanu kā pašsaprotamu, ka to vajag zobu veselības dēḷ. Neliela daḷa respondentu atsakās no zobu tīrīšanas, bet izdara to pieaugušo uzraudzībā vai atsakās no zobu tīrīšanas pat pieaugušo uzraudzībā (skat. 3.15. attēlu). 


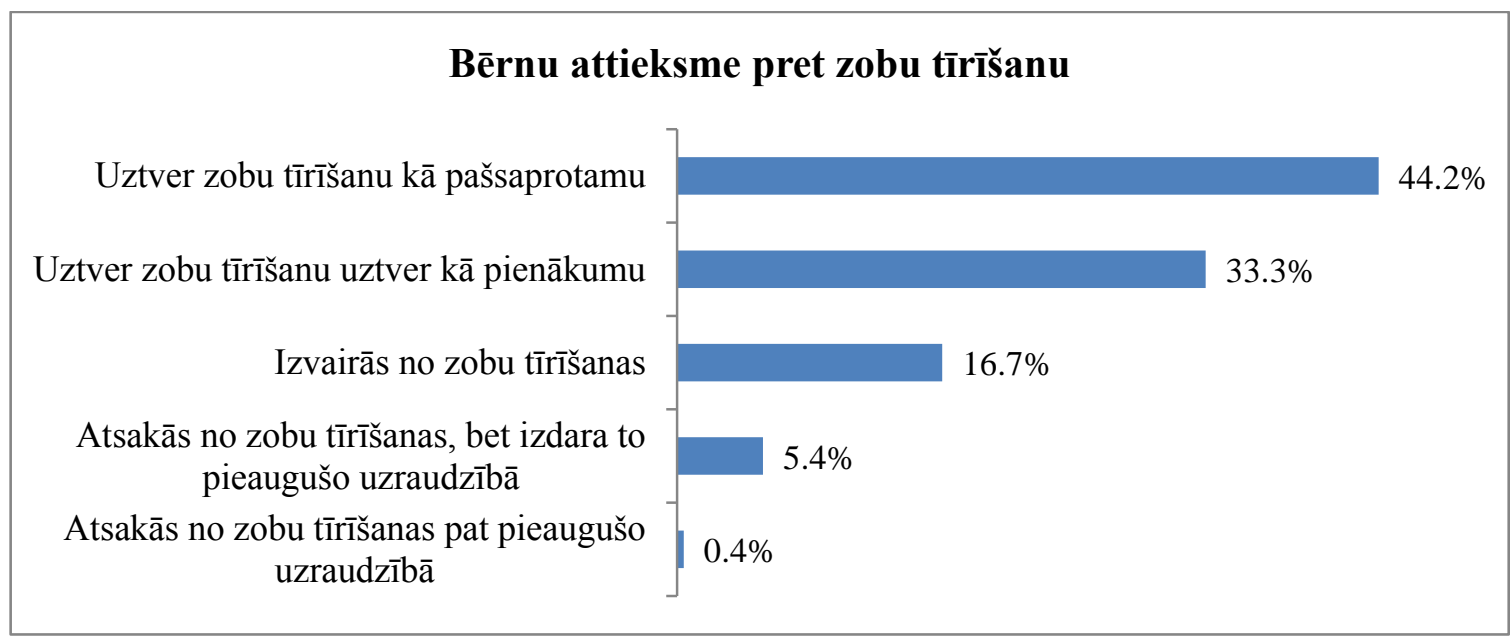

3.15. attēls. Procentuālais sadalījums bērnu attieksmju veidiem pret zobu tīrī̌sanu

Divdesmit pieci respondenti jeb 10,4\% norādīja, ka lieto fluora tabletes regulāri, 42 respondenti jeb 17,5\% lieto fluora tabletes neregulāri, 98 respondenti jeb 40,8\% norādīja, ka agrāk bērni lietojuši fluora tabletes, bet aptaujas veikšanas brīdī vairs nē, savukārt 75 respondenti jeb 31,3\% atzina, ka nelieto un nekad nav lietojuši fluora tabletes.

\subsubsection{Bērna rakstura iez̄imju un uzvedības bloks}

Vecāku atzīmētais bērna sabiedriskums tika vērtēts Likerta skalā no 1 (dod priekšroku vienatnei) līdz 10 (ļoti labprāt uzturas cilvēkos). Vidējā balle bija $M=8,08$ ( $S D=1,96$, min. -1 , maks. $-10, \mathrm{n}=238$ ). Vecāku norādītajai bērna aktivitātei, vērtējot no 1 (nav aktīvs, âtri nogurst) līdz 10 (aktīvi darbojas visu dienu) vidējā balle bija $M=8,33$ ( $S D=1,77$, min. - 1, maks. - 10, n = 240). Vecāku vērtējumā impulsivitātei no 1 (var ilgstoši darīt kaut ko vienu) līdz 10 (nepārtraukti pārslēdzas uz jaunām darbībām) vidējā balle bija 6,26 $(S D=2,17$, min. -1 , maks. $-10, \mathrm{n}=240)$.

Vecāku atzīmētajai emocionālajai labilitātei, kas tika vērtēta no 1 (noskaņojums ir noturīgs, stabils) līdz 10 (ātri mainās noskaņojums) vidējā balle bija 6,15 ( $S D=2,32$, min. - 1, maks. - 10, n = 240). Vecāku vērtējumā bērna emocionalitāte no 1 (nepauž emocijas) līdz 10 (emocijas ir spilgtas, acīmredzamas) tika raksturota ar vidējo balli 7,85 $(S D=1,83$, min. -1 , maks. $-10, \mathrm{n}=238)$. Savukārt bērna kautrīgums ballēs no 1 (lēni iejūtas jaunās attiecībās ar cilvēkiem) līdz 10 (ātri iejūtas jaunās attiecībās) tika vērtēts vidēji ar 6,71 ballēm $(S D=2,31$, min. -1 , maks. $-10, \mathrm{n}=238)$.

Bērna vispārējo trauksmi (satraucamību) vecāki novērtēja ar jautājumu, vai bērns parasti ir viegli satraucams. Atbildes tika novērtētas 4 ballu skalā no 1 (nav īpaši satraucams) līdz 4 (pārsvarā ir satraucams). Vidējais vērtējums bija 2,17 balles $(S D=0,80$, min. - 1 , 
maks. - 4, n = 237). Uz jautājumu, vai bērns pats spēj tikt galā ar savu satraukumu piedāvātās atbildes bija analogiskas iepriekšējam jautājumam. Vidējais vērtējums šajā jautājumā bija 1,77 (SD = 0,62, min. - 1, maks. - 4, n = 237). Savukārt uz jautājumu, cik ilgi bērns pārdzīvo kādu satraucošu notikumu, piedāvātās atbildes variēja no 1 (vairākas minūtes) līdz 4 (vairākas dienas). Vidējais vērtējums bija 2,08 ( $S D=1,01$, min. -1 , maks. $-4, \mathrm{n}=236)$.

Tika uzdota arī jautājums par biežākajiem, ar zobārstu nesaistītiem baiḷu iemesliem. Visvairāk bērnu (gandrīz 40\%) baidījās no tumsas un zirnekḷiem/kukaiṇiem (36,67\%), savukārt vismazāk respondentu atzīmēja bailes no slēgtām telpām un citu baiḷu iemeslu, piemēram, no Rūķa vai, piemēram, neuzvarēt šaha turnīrā (skat. 3.16. attēlu). Vidēji bērni atzīmēja 1, $92(S D=1,29, \mathrm{n}=240)$ baiļu iemeslus, bet atzīmēto atbilžu skaits variēja no 0 līdz 7.

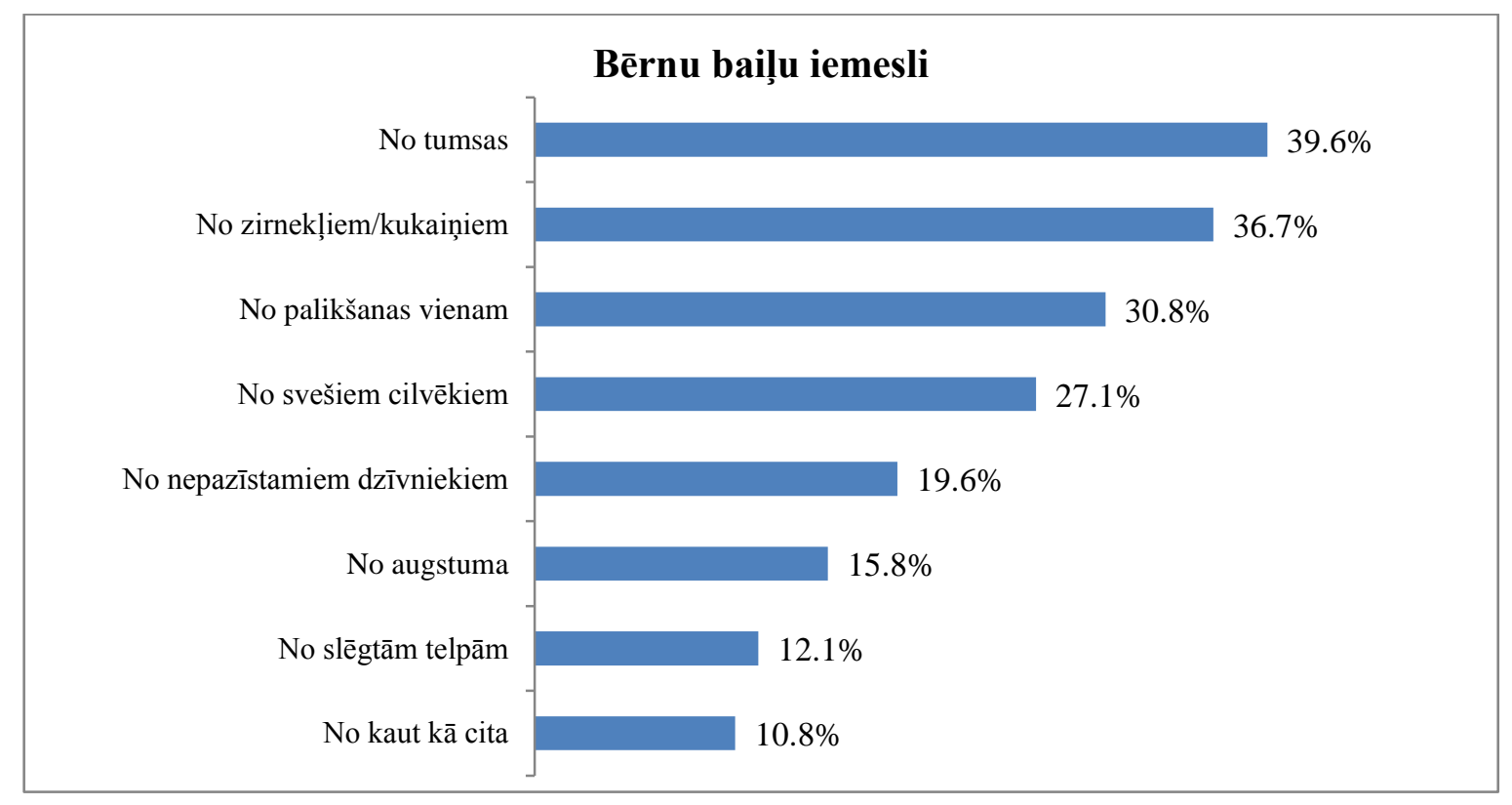

3.16. attēls. Procentuālais sadalījums bērnu baiḷu iemeslu veidiem (izṇemot zobārstu)

\subsubsection{Gimenes stresa bloks}

No stresa faktoriem, kas saistīti ar gimeni, visvairāk - 12,1\% respondentu atzīmēja kāda gimenes locekḷa pārvākšanos uz citu dzīvesvietu. Vienāds skaits respondentu - 10,8\% pieminēja kāda gímenes locekḷa nāvi un jauna gímenes locekḷa ienākšanu gímenē. Mazāk (9,2\% respondentu) bija kāda ǵimenes locekḷa veselības pasliktināšanās, 8,8\% respondentu atzīmēja nopietnus strīdus ǵimenē un 4,6\% respondentu - šķiršanos vai ğimenes izjukšanu.

No personiskajiem faktoriem visbiežāk - 33,8\% respondentu atzīmēja atvalinājumu, 19,6\% gadījumu respondentiem bija miega traucējumi, 17,1\% - jūtamas dzīves apstākḷu izmaiņas. Mazāk gadījumos - 12,5\% respondentu atzīmēja tuva drauga nāvi vai attiecību 
izjukšanu, 7,9\% - dz̄ivesvietas maiṇu, 5\% - nopietnu slimību, bet 1,3\% - nepatikšanas ar varas iestādēm.

Visbiežāk atzīmētais ar darbu saistītais stresors bijis pārmaiņas darba mikroklimatā vai apstākḷlos - 24,6\% gadījumos, 12,5\% respondentu atzīmējuši darba vietas maiņu, 8,3\% - pārmaiņas karjerā, 5,8\% respondentu bijis konflikts ar priekšniecību, bet 5\% respondenti atlaisti no darba. Neviens respondents nebija atzīmējis aiziešanu pensijā.

Person̄̄gos stresa faktorus bija atzīmējuši apmēram puse respondentu (vidēji 0,56, $S D=0,69$, min. -0 , maks. $-4, \mathrm{n}=239)$, līdzīgi rezultāti bija arī ar darbu saistītiem stresa faktoriem (vidēji 0,56, $S D=0,64$, min. -0 , maks. $-3, \mathrm{n}=240$ ). Nedaudz vairāk respondentu bija atzīmējuši stresorus saistībā ar ǵimeni - vidēji 0,62 (SD =0,84, min. - 0, maks. - 5, $\mathrm{n}=240$ ). Piecdesmit viens respondents nebija atzīmējis nevienu no stresa faktoriem, bet vidēji respondenti bija atzīmējuši 1,73 stresorus $(S D=1,56$, min. -0 , maks. $-8, \mathrm{n}=240)$.

\subsection{Secinošās statistikas rezultāti}

Šajā nodaļā tiks parādīta baiḷu un trauksmes zobārstniecībā saistība ar bērna iekšējiem faktoriem, kā dzimumu un vecumu, kā arī bērna uzvedību zobārsta kabinetā, vecāku bailēm un trauksmi zobārstniecībā, vecāku/informācijas un ǵimenes sociāldemogrāfiskajiem un stresa faktoriem, bērna medicīnisko un zobārstniecības pieredzi, bērna personības faktoriem, kā arī mutes veselības un mutes kopšanas faktoriem.

\subsubsection{Bērnu bailes no zobārsta (BTZ), bērnu dzimums un vecums}

Bērnu bailēm no zobārsta bija statistiski nozīmīga negatīva korelācija ar bērnu vecumu, t.i., jo vecāks bija bērns, jo zemāks bija bērna baiļu no zobārsta līmenis ( $\mathrm{r}=-0,234$, $\mathrm{p}<0.001$ ). Visaugstākais vidējais bērnu baiḷu līmenis bija 4 gadu vecumā (sk. 3.1. attēlu), savukārt viszemākais - 12 gadu vecumā. Tomēr, kā jau minēts 3.1. nodal̦āa, baiḷu līmeņa samazināšanās nenotika lineāri, jo sešgadniekiem bija trešais zemākais baiḷu līmenis, savukārt vienpadsmit gadus veciem bērniem - viens no augstākajiem baiḷu no zobārsta līmeṇiem.

Vidēji zēniem bija augstāks baiļu no zobārsta līmenis nekā meitenēm - attiecīgi, $M=33,13(S D=12,30)$ un $M=31,80(S D=9,50)$, tomēr atšķirīibas nebija statistiski nozīmīgas $(\mathrm{t}=0,94, \mathrm{p}=0,35)$. Visaugstākais vidējais baiļu līmenis bija četrgadīgiem zēniem - $M=42,12(S D=14,59)$, savukārt viszemākais vidējais baiḷu līmenis bija divpadsmitgadīgiem zēniem $-M=26,58(S D=8,24)$ un desmitgadīgām meitenēm $M=27,62(S D=7,41)$ (skat. 3.7. tabulu). 
3.7. tabula

Bērnu baiḷu pārskata zobārstniecības skalas (CFSS-DS) aprakstošās statistikas rādītāji pēc vecuma un dzimuma

\begin{tabular}{|l|c|r|r|r|r|r|c|c|c|}
\hline \multirow{2}{*}{$\begin{array}{l}\text { Bērnu } \\
\text { vecums }\end{array}$} & \multicolumn{3}{|c|}{ Kopējā izlase } & \multicolumn{3}{c|}{ Zēnu izlase } & \multicolumn{3}{c|}{ Meitenu izlase } \\
\cline { 2 - 10 } & $\mathrm{n}$ & $M$ & \multicolumn{1}{c|}{$S D$} & $\mathrm{~N}$ & $M$ & \multicolumn{1}{c|}{$S D$} & $\mathrm{~N}$ & \multicolumn{1}{c|}{$M$} & \multicolumn{1}{c|}{$S D$} \\
\hline 4 & 30 & 39,57 & 13,07 & 16 & 42,12 & 14,59 & 14 & 36,64 & 10,88 \\
\hline 5 & 25 & 35,72 & 12,23 & 11 & 37,09 & 14,55 & 14 & 34,64 & 10,51 \\
\hline 6 & 27 & 30,33 & 9,66 & 13 & 31,08 & 10,59 & 14 & 29,64 & 9,07 \\
\hline 7 & 25 & 31,32 & 9,91 & 12 & 32,17 & 10,10 & 13 & 30,54 & 10,07 \\
\hline 8 & 28 & 33,32 & 11,42 & 15 & 34,07 & 12,44 & 13 & 32,46 & 10,54 \\
\hline 9 & 26 & 31,23 & 7,58 & 14 & 30,21 & 8,41 & 12 & 32,42 & 6,64 \\
\hline 10 & 25 & 27,84 & 7,60 & 12 & 28,08 & 8,13 & 13 & 27,62 & 7,41 \\
\hline 11 & 28 & 33,61 & 12,50 & 13 & 34,38 & 15,44 & 15 & 32,93 & 9,79 \\
\hline 12 & 26 & 27,85 & 8,33 & 12 & 26,58 & 8,24 & 14 & 28,93 & 8,55 \\
\hline Kopā & 240 & 32,45 & 10,97 & 118 & 33,13 & 12,30 & 122 & 31,80 & 9,50 \\
\hline
\end{tabular}

\subsubsection{BTZ un mutes veselības saistība}

Bērnu bailēm no zobārsta bija statistiski nozīmīga pozitīva saistība gan ar kariozo zobu skaitu (piena un pastāvīgajiem zobiem), gan ar kopējo KPE (KPE + kp) un kp (skat. 3.8. tabulu). Netika konstatēta statistiski nozīmīga korelācija ar plombēto zobu skaitu (piena un pastāvīgajiem zobiem), ne arī ar ekstrahēto zobu skaitu.

3.8. tabula

Kariozo, plombēto un ekstrahēto zobu skaita (KPE un kp) pastāvīgajiem un piena zobiem saistība ar bērnu bailēm no zobārsta (CFSS-DS)

\begin{tabular}{|c|c|c|}
\hline Zobu veselības rādītāji: & $\begin{array}{c}\text { Pīrsona korelācija ar bērnu } \\
\text { bailēm no zobārsta (r) }\end{array}$ & p vērtība \\
\hline Kopējais KPE (KPE + kp) & 0,28 & 0,000 \\
\hline Past.zobiem (KPE) & 0,07 & 0,340 \\
\hline Piena zobiem (kp) & 0,33 & 0,000 \\
\hline Kopā kariozi zobi (K+ k) & 0,42 & 0,000 \\
\hline Past.zobiem (K) & 0,17 & 0,021 \\
\hline Piena zobiem (k) & 0,43 & 0,000 \\
\hline Kopā plombēti zobi (P+ p) & $-0,11$ & 0,079 \\
\hline Past.zobiem (P) & $-0,05$ & 0,486 \\
\hline Piena zobiem (p) & $-0,05$ & 0,445 \\
\hline Kopā ekstrahēti zobi (E) & $-0,07$ & 0,378 \\
\hline
\end{tabular}

\subsubsection{BTZ un bērna uzvedības zobārsta kabinetā saistība.}

Pārbaudot saistību starp bērnu bailēm no zobārsta (CFSS-DS) un bērna uzvedību zobārsta krēslā (Frankla skalā), Pīrsona $r=-0,69(\mathrm{p}<0,000)$. Jo izteiktākas bija bērna bailes no zobārsta novērtējums, jo negatīvāka bija bērna uzvedība zobārsta krēslā. 


\subsubsection{Bērnu un vecāku baiḷu no zobārsta saistība}

Pārbaudot saistību starp bērnu un vecāku bailēm no zobārsta, Pīrsona $r=0,28$ $(\mathrm{p}<0,000)$. Tas nozīmē, jo izteiktākas bija vecāku bailes no zobārsta, jo stiprākas bija arī bērnu bailes no zobārsta.

\subsubsection{BTZ saistība ar dažādiem psihosociālajiem faktoriem}

Šajā nodaļā tiks parādīta bērnu baiḷu un trauksmes saistība ar dažādiem psihosociālajiem faktoriem, kā vecāku/informācijas un ǵimenes sociāldemogrāfiskajiem un stresa faktoriem, bērna medicīnisko un zobārstniecības pieredzi, bērna personības faktoriem, kā arī mutes veselības un mutes kopšanas faktoriem.

\subsubsection{Saistība ar sociālekonomiskajiem faktoriem}

Pārbaudot saistību starp bērnu bailēm no zobārsta un gimenes sociālekonomiskajiem faktoriem, tika konstatēta statistiski nozīmīga negatīva korelācija ar gimenes locekḷu skaitu (Pīrsona $\mathrm{r}=-0,21, \mathrm{p}=0,001$ ), mājsaimniecībā dzīvojošo skaitu (P̄̄rsona $\mathrm{r}=-0,17$, $\mathrm{p}=0,008)$ un bērnu skaitu ğimenē (Pīrsona $\mathrm{r}=-0,21, \mathrm{p}=0,001)$ (skat. 3.9. tabulu).

3.9. tabula

Bērnu baiļu no zobārsta saistība ar sociālekonomiskajiem faktoriem

\begin{tabular}{|l|c|c|}
\hline Sociālekonomiskie faktori & $\begin{array}{c}\text { Pīrsona korelācija ar bērnu } \\
\text { bailēm no zobārsta (r) }\end{array}$ & p vērtība \\
\hline Ģimenes locekḷu skaits & $-0,21$ & 0,001 \\
\hline Mājsaimniecības locekḷu skaits & $-0,17$ & 0,008 \\
\hline Bērnu skaits & $-0,21$ & 0,001 \\
\hline Ģimenes stāvoklis (prec.) & $-0,12$ & 0,059 \\
\hline Ģimenes stāvoklis (kopā) & $-0,07$ & 0,315 \\
\hline Mātes vecums & $-0,11$ & 0,090 \\
\hline Tēva vecums & $-0,04$ & 0,499 \\
\hline Mātes izglītība & $-0,10$ & 0,122 \\
\hline Tēva izglīīîa & $-0,14$ & 0,044 \\
\hline Mātes nodarbinātība & $-0,01$ & 0,844 \\
\hline Tēva nodarbinātība & $-0,00$ & 0,958 \\
\hline Ģimenes ienākumu līmenis & 0,05 & 0,454 \\
\hline
\end{tabular}

Tas nozīmē, jo lielākas bija ğimenes un mājsaimniecības un vairāk bērnu gimenē, jo mazākas bija bērnu bailes no zobārsta. Statistiski nozīmīga negatīva korelācija tika konstatēta arī ar 
tēva izglītību (Pīrsona $\mathrm{r}=-0,14, \mathrm{p}=0,04)$. Tātad, jo augstāka bija tēvu izglìtīiba, jo mazākas bija bērnu bailes no zobārsta.

\subsubsection{Saistība ar bērnu medicīnisko pieredzi un attieksmi}

Pārbaudot saistību starp bērnu bailēm no zobārsta, bērnu medicīnisko pieredzi un attieksmi pret ārstiem (izṇemot zobārstus), tika konstatēta statistiski nozīmīga pozitīva korelācija ar bērnu slimošanas biežumu ( $\mathrm{r}=0,13, \mathrm{p}=0,047)$, ārsta apmeklējumu vairāk nekā 4 reizes gadā $(r=0,19, p=0,003)$, piesardzīgu attieksmi pret ārstiem $(r=0,28, p<0,001)$ un bailīgu attieksmi pret ārstiem $(\mathrm{r}=0,41, \mathrm{p}<0,001), \mathrm{ka}$ arī traumatisku pieredzi pie ārstiem, izṇemot zobārstus $(r=0,14, p=0,03)$ (skat. 3.10. tabulu).

3.10. tabula

Bērnu baiļu no zobārsta saistība ar bērnu medicīnisko pieredzi un attieksmi pret ārstiem

\begin{tabular}{|c|c|c|c|}
\hline $\begin{array}{l}\text { Bērnu medicīniskās pieredzes un } \\
\text { attieksmes faktori }\end{array}$ & $\begin{array}{c}\text { Respondentu } \\
\text { skaits }\end{array}$ & $\begin{array}{c}\text { Pīrsona korelācija ar bērnu } \\
\text { bailēm no zobārsta (r) }\end{array}$ & p vērtība \\
\hline Hroniskas saslimšanas & 240 & 0,02 & 0,786 \\
\hline Bērnu slimošanas biežums & 240 & 0,13 & 0,047 \\
\hline Ārstu apmeklēšanas biežums & 238 & 0,13 & 0,053 \\
\hline Ārstu apmeklē vairāk nekā 4x gadā & 238 & 0,19 & 0,003 \\
\hline Draudzīga attieksme pret ārstiem & 240 & $-0,30$ & 0,000 \\
\hline Neitrāla attieksme pret ārstiem & 240 & $-0,26$ & 0,000 \\
\hline Piesardzīga attieksme pret ārstiem & 240 & 0,28 & 0,000 \\
\hline Bailīga attieksme pret ārstiem & 240 & 0,41 & 0,000 \\
\hline Ārsta apmeklējumu biežums & 239 & 0,11 & 0,099 \\
\hline Traumatiska pieredze pie ārstiem & 238 & 0,14 & 0,030 \\
\hline Traumatisku pieredžu skaits & 44 & 0,27 & 0,081 \\
\hline Traumatiskās pieredzes vecums & 41 & 0,05 & 0,770 \\
\hline Ārstēšanās slimnīcā & 240 & $-0,05$ & 0,485 \\
\hline Ārstēšanos slimnīcā skaits & 135 & 0,07 & 0,409 \\
\hline Ārstēšanos slimnīcā vecums & 128 & $-0,16$ & 0,069 \\
\hline Ārstēšana vispārējā narkozē & 240 & $-0,07$ & 0,290 \\
\hline Ārstēšanos vispārējā narkozē skaits & 71 & $-0,17$ & 0,161 \\
\hline Ārstěšanos vispārējā narkozē vecums & 69 & $-0,14$ & 0,237 \\
\hline Bērna fiziskas traumas (izņemot zobus) & 240 & 0,01 & 0,936 \\
\hline Bērna fizisku traumu reizes & 72 & 0,00 & 0,975 \\
\hline Bērna fizisku traumu vecums & 65 & $-0,25$ & 0,044 \\
\hline
\end{tabular}

Bailes no zobārsta statistiski nozīmīgi negatīvi korelē ar draudzīgu attieksmi pret ārstiem $(\mathrm{r}=-0,30, \mathrm{p}<0,001)$, neitrālu attieksmi pret ārstiem $(\mathrm{r}=-0,26, \mathrm{p}<0,001), \mathrm{ka}$ arī bērna vecumu, ciešot pirmo fizisko traumu, kuras dēl bija nepieciešama neatliekamā palīdzība $(\mathrm{r}=-0,25, \mathrm{p}=0,044)$. Tas nozīmē, jo agrākā vecumā bērni cietuši no kādas smagas fiziskās traumas, jo biežāk šie bērni ir slimojuši un apmeklējuši ārstu, un jo piesardzīgāka un bailīgāka 
bija viṇu attieksme pret ārstiem vispār, jo lielākas ir arī viṇu bailes no zobārsta. Netika konstatēta bērnu baiḷu no zobārsta statistiski nozīmīga korelācija ar hroniskām saslimšanām.

\subsubsection{Saistība ar bērnu zobārstniecības pieredzi un attieksmi}

Pārbaudot saistību starp bērnu bailēm no zobārsta, bērnu zobārstniecības pieredzi un attieksmi pret zobārstiem, tika konstatēta cieša statistiski nozīmīga pozitīva korelācija ar grūtībām iepriekšējās zobu ārstēšanas laikā $(r=0,68, p<0,001)$, kā arī ar bērna bailēm un raudāšanu, ejot pie zobārsta $(r=0,55, \mathrm{p}<0,001)$ (skat. 3.11. tabulu). Tāpat bija statistiski nozīmīga pozitīva korelācija ar bērna paniku un histēriju, ejot pie zobārsta $(r=0,34$, $\mathrm{p}<0,001)$, bērna aktīvu protestu un pretestību, ejot pie zobārsta $(\mathrm{r}=0,30, \mathrm{p}<0,001)$, negatīvu pieredzi pie zobārsta $(\mathrm{r}=0,30, \mathrm{p}<0,001)$ un negatīvas pieredzes pārvarēšanu, ārstējot zobus vispārējā anestēzijā $(\mathrm{r}=0,31, \mathrm{p}=0,003)$, bērnam veiktu zobu ārstēšanu vispārējā anestēzijā $(r=0,28, p<0,001)$, bērna nevešanu pie zobārsta vispār $(r=0,19$, $\mathrm{p}=0,003)$ un bērna vešanu pie zobārsta dienas pirmajā pusē $(\mathrm{r}=0,13, \mathrm{p}=0,042)$ (skat. 3.11. tabulu). Tas nozīmē, ka bērni ar lielākām bailēm no zobārsta biežāk izrāda bailes un raud vai aktīvi protestē, vai krīt panikā vai histērijā, ejot pie zobārsta, viņiem ir bijusi negatīva pieredze pie zobārsta, zobu ārstēšana vienmēr vai gandrīz vienmēr noritējusi ar lielām grūtībām, un zobi ir ārstēti vispārējā narkozē.

Savukārt statistiski nozīmīga negatīva korelācija bailēm no zobārsta tika konstatēta ar bērna neitrālu attieksmi, ejot pie zobārsta $(r=-0,36, p<0,001)$ un bērna prieku un interesi, ejot pie zobārsta $(r=-0,29, \mathrm{p}<0,001)$, bērnam iepriekš veiktu zobu higiēnu $(\mathrm{r}=-0,24$, $\mathrm{p}<0,001)$, iepriekš veiktu plombēšanu vietējā anestēzijā $(\mathrm{r}=-0,18, \mathrm{p}=0,005)$ un vecāku nosaukto bērna vecumu (mēnešos) pirmā zobārsta apmeklējuma laikā $(r=-0,16, p=0,011)$ (skat. 3.11. tabulu). Tas nozīmēe, bērniem, kuriem ir veikta zobu higiēna un ārstēšana ar atsāpināšanu, un ir pozitīva vai neitrāla attieksme pret zobārstu, ir mazākas bailes no zobārsta.

Bērnu bailēm no zobārsta nebija statistiski nozīmīgas korelācijas ar bērnam veiktu zobu apskati, zobu plombēšanu bez anestēzijas, zoba ekstrakciju vietējā anestēzijā, vešanu pie zobārsta, kad zobi nedaudz sāp vai traucē, pirmo zobārsta vizīti sakarā ar pamanītām izmaiņām zobos, negatīvās pieredzes pārvarēšanu, dodoties pie zobu higiēnista, kāar ari zobārsta apmeklējumu dažādos dienas laikos. 
3.11. tabula

Bērnu baiḷu no zobārsta saistība ar bērnu pieredzi pie zobārsta un attieksmi pret zobārstiem

\begin{tabular}{|c|c|c|}
\hline $\begin{array}{l}\text { Bērnu zobārstniecības pieredzes un attieksmes } \\
\text { faktori }\end{array}$ & $\begin{array}{l}\text { Pīrsona korelācija ar bērnu } \\
\text { bailēm no zobārsta (r) }\end{array}$ & p vērtība \\
\hline Pirmā vizīte, lai iepazītu kabinetu & $-0,16$ & 0,011 \\
\hline Pirmā vizīte pēc cita ārsta nosūtījuma & 0,08 & 0,245 \\
\hline Pirmā vizīte, jo ievēroja izmaiņas zobos & 0,03 & 0,676 \\
\hline Pirmā vizīte zobu sāpju dēḷ & 0,07 & 0,314 \\
\hline Apmeklējumu regularitāte & 0,08 & 0,209 \\
\hline Pie zobārsta ved katru gadu noteiktos laikos & $-0,09$ & 0,150 \\
\hline Pie zobārsta ved, kad atceras & $-0,15$ & 0,023 \\
\hline Pie zobārsta ved, kad ievēro izmaiņas zobos & 0,12 & 0,067 \\
\hline Pie zobārsta ved, kad nedaudz sāp vai traucē & 0,01 & 0,866 \\
\hline Pie zobārsta ved, kad ir ilgstošas sāpes & 0,09 & 0,172 \\
\hline Pie zobārsta neved vispār & 0,19 & 0,003 \\
\hline Bērnam ir veikta apskate, konsultācija & 0,00 & 0,967 \\
\hline Bērnam ir veikta zobu higiēna & $-0,24$ & 0,000 \\
\hline Bērnam ir veikta plombēšana bez anestēzijas & $-0,01$ & 0,837 \\
\hline Bērnam ir veikta plombēšana ar vietējo anestēziju & $-0,18$ & 0,005 \\
\hline Bērnam ir veikta plombēšana vispārējā anestēzijā & 0,28 & 0,000 \\
\hline Bērnam ir veikta ekstrakcija vietējā anestēzijā & $-0,02$ & 0,797 \\
\hline Bērnam ir veikta ekstrakcija vispārējā anestēzijā & 0,12 & 0,067 \\
\hline Bērnam ir veikta ekstrakcija bez anestēzijas & $-0,12$ & 0,056 \\
\hline Bērnam ir veikta cita ārstēšana & 0,04 & 0,590 \\
\hline Ārstēšanas procesa norise (cik grūti) & 0,68 & 0,000 \\
\hline Ejot pie zobārsta prieks, interese & $-0,29$ & 0,000 \\
\hline Ejot pie zobārsta neitrāla attieksme & $-0,36$ & 0,000 \\
\hline Ejot pie zobārsta satraukums, bažas & 0,10 & 0,115 \\
\hline Ejot pie zobārsta bailes, raudāšana & 0,55 & 0,000 \\
\hline Ejot pie zobārsta aktīvs protests, pretestība & 0,30 & 0,000 \\
\hline Ejot pie zobārsta panika, histērija & 0,34 & 0,000 \\
\hline Negatīva pieredze (NP) pie zobārsta & 0,30 & 0,000 \\
\hline Pēc NP gāja pie higiēnista & 0,03 & 0,790 \\
\hline Pēc NP gāja pie tā paša zobārsta & 0,13 & 0,205 \\
\hline Pēc NP gāja pie cita zobārsta/uz citu klīniku & 0,16 & 0,143 \\
\hline Pēc NP ārstēja zobus vispārējā anestēzijā & 0,31 & 0,003 \\
\hline Pēc NP nogaidīja, neko nedarīja & $-0,16$ & 0,127 \\
\hline Pie zobārsta ved dienas pirmajā pusē & 0,13 & 0,042 \\
\hline Pie zobārsta ved pēcpusdienā & $-0,07$ & 0,270 \\
\hline Pie zobārsta ved vakarā & $-0,08$ & 0,214 \\
\hline Pie zobārsta ved dažādos laikos & $-0,01$ & 0,914 \\
\hline
\end{tabular}

\subsubsection{Saistība ar vecāku un informācijas faktoriem}

Pārbaudot bērnu baiļu no zobārsta saistību ar vecāku un informācijas faktoriem, tika konstatēta statistiski nozīmīga korelācija ar vecāku bailēm no zobārsta $(r=0,28, p<0,001)$, kā arī vairākām bērna sagatavošanas metodēm, ko veic vecāki pirms zobārsta apmeklējuma, piemēram, apsola balvu par labu uzvedību pie zobārsta $(\mathrm{r}=0,25, \mathrm{p}<0,001)$, mierina, ka neko nedarīs un nekas nesāpēs $(r=0,22, p=0,001)$, lasa bērnam priekšā grāmatas par zobārstiem 
( $r=0,18, p=0,007)$, stāsta par savu pieredzi pie zobārsta $(r=0,15, p=0,018)$. Tāpat bailes no zobārsta statistiski nozīmīgi korelē ar faktu, ka vecāki saņem informāciju par bērnu zobu kopšanu no plašsaziņas līdzekḷiem $(r=0,16, p=0,011)$ vai draugiem un paziņām $(r=0,14$, $\mathrm{p}=0,03)$, kā arī par bērna sagatavošanu zobārsta apmeklējumam uzzina no draugiem un paziņām $(\mathrm{r}=0,21, \mathrm{p}=0,001)$. Bērnu bailes no zobārsta pozitīivi korelē arī tā pieaugušā pavadību pie zobārsta, kuru bērns klausa $(\mathrm{r}=0,14, \mathrm{p}=0,03)$, un teikšanu, lai bērns neuztraucas pirms svarīgiem notikumiem $(r=0,17, p=0,008)$, samīḷošanu, kad bērns bēdīgs $(\mathrm{r}=0,16, \mathrm{p}=0,012)$, un bērna iedrošināšanu un uzslavēšanu pirms svarīgiem notikumiem $(r=0,15, p=0,019)$ (skat. 3.12. tabulu).

3.12. tabula

Bērnu baiḷu no zobārsta saistība ar vecāku un informācijas faktoriem

\begin{tabular}{|c|c|c|}
\hline Vecāku un informācijas faktori & $\begin{array}{l}\text { Pīrsona korelācija ar bērnu } \\
\text { bailēm no zobārsta (r) }\end{array}$ & p vērtība \\
\hline Vecāku bailes no zobārsta & 0,28 & 0,000 \\
\hline Lasa priekšā grāmatas par zobārstiem & 0,18 & 0,007 \\
\hline Mierina, ka neko nedarīs un nekas nesāpēs & 0,22 & 0,001 \\
\hline Stāsta par savu pieredzi pie zobārsta & 0,15 & 0,018 \\
\hline N̦em līdzi pie sava zobārsta & 0,12 & 0,076 \\
\hline Apsola balvu par labu uzvedību pie zobārsta & 0,25 & 0,000 \\
\hline Nekā īpaši negatavo & $-0,23$ & 0,000 \\
\hline Pavada māte & 0,05 & 0,428 \\
\hline Pavada tēvs & $-0,07$ & 0,299 \\
\hline Pavada pieaugušais, kam ir laiks & $-0,12$ & 0,059 \\
\hline Pavada pieaugušais, kuru bērns klausa & 0,14 & 0,030 \\
\hline Pavada jebkurš no pieaugušajiem gimenes loc. & 0,08 & 0,242 \\
\hline Informāciju par zobu kopšanu saṇem no ğim. ārsta & 0,11 & 0,087 \\
\hline No zobārsta & $-0,22$ & 0,001 \\
\hline No zobu higiēnista & $-0,17$ & 0,007 \\
\hline No plašsaziņas līdzekḷiem & 0,16 & 0,011 \\
\hline No draugiem un paziṇām & 0,14 & 0,030 \\
\hline Nekur nesaņem informāciju par zobu kopšanu & 0,01 & 0,872 \\
\hline $\begin{array}{l}\text { Informāciju par bērna sagatavošanu vizītei pie } \\
\text { zobārsta saṇem no gimenes ārsta }\end{array}$ & 0,10 & 0,143 \\
\hline No zobārsta & 0,04 & 0,577 \\
\hline No zobu higiēnista & $-0,04$ & 0,538 \\
\hline No plašsaziṇas līdzekḷiem & 0,08 & 0,246 \\
\hline No draugiem un paziṇām & 0,21 & 0,001 \\
\hline Nekur nesaṇem inform. par bērna sagatavošanu & $-0,10$ & 0,119 \\
\hline Samīlo, kad satraucies vai nobijies & 0,13 & 0,051 \\
\hline Saka, lai neuztraucas, kad satraucies vai nobijies & $-0,04$ & 0,499 \\
\hline Samīḷ, kad bēdīgs & 0,16 & 0,012 \\
\hline Saka, lai neuztraucas, kad bēdīgs & 0,01 & 0,937 \\
\hline Iedrošina un uzslavē pirms svarīga notikuma & 0,15 & 0,019 \\
\hline Saka, lai neuztraucas pirms svarīga notikuma & 0,17 & 0,008 \\
\hline Pārrunā savu nepatīkamo pieredzi bērna klātbūtnē & 0,05 & 0,445 \\
\hline Baida bērnu ar zobārstu & $-0,02$ & 0,777 \\
\hline Ir atlikuši zobārsta vizīti nebūtiska iemesla dēl & $-0,02$ & 0,731 \\
\hline
\end{tabular}


Tas nozīmē, ka to vecāku, kam ir bailes no zobārsta un kas pirms vizītes skaidro, ka „pie zobārsta neko nedarīs un nekas nesāpēs”, ,,apsola balvas par labu uzvedību”, bērniem ir lielākas bailes no zobārsta. Tāpat bērniem ir lielākas bailes no zobārsta, ja informāciju par mutes dobuma kopšanu vai bērna sagatavošanu šie vecāki saņem plašsaziņas līdzekḷos un pie draugiem un paziņām, nevis pie zobārstiem vai zobu higiēnistiem.

Savukārt statistiski nozīmīgi negatīvi bailes no zobārsta korelēja ar atbildi „,nekā īpaši negatavo” bērnu pirms zobārsta apmeklējuma $(r=-0,23, p<0,001)$, informācijas saṇemšanu par zobu kopšanu no zobārsta $(r=-0,22, p=0,001)$ vai zobu higiēnista $(r=-0,17$, $\mathrm{p}=0,007$ ) (skat. 3.12. tabulu). Tas nozīmē, ka bērniem, kurus vecāki nekā īpaši nesagatavoja pirms zobārsta vizītes, kā arī pārrunāja bērna mutes kopšanas paradumus ar zobārstniecības speciālistiem, bija zemāks baiḷu no zobārsta līmenis.

Statistiski nozīmīgas korelācijas netika konstatēta bērnu bailēm no zobārsta un bērna biedēšanai ar zobārstu kā soda metodi, zobārsta vizītes atlikšanai bez īpaša iemesla un vecāku negatīiās pieredzes pārrunāšanai bērna klātbūtnē.

3.13. tabula

Atšķiīības bērnu baiḷu no zobārsta līmen̄i atkarībā no tā, kā vecāki paskaidro/sagatavo bērnu vizītei pie zobārsta

\begin{tabular}{|c|c|c|c|c|c|}
\hline Sagatavošanas veids & $\begin{array}{l}\text { Respondentu } \\
\text { skaits (n) }\end{array}$ & $\begin{array}{c}\text { CFSS-DS } \\
(\mathrm{M})\end{array}$ & $S D$ & $\begin{array}{c}\text { ANCOVA } \\
\mathrm{F}_{(1,240)} \\
\end{array}$ & p vērtība \\
\hline \multirow{2}{*}{$\begin{array}{l}\text { Apskata un lasa priekšā bērnu } \\
\text { grāmatas par šo tēmu, pārrunā } \\
\text { redzēto un lasīto }\end{array}$} & $\mathrm{Ja}(\mathrm{n}=35)$ & 37,09 & 12,11 & \multirow{2}{*}{3,44} & \multirow{2}{*}{0,065} \\
\hline & $\mathrm{Ne \overline { }}(\mathrm{n}=205)$ & 31,66 & 10,59 & & \\
\hline \multirow{2}{*}{$\begin{array}{l}\text { Mierina, ka zobārsts tikai } \\
\text { apskatīs zobus, neko nedarīs un } \\
\text { nekas nesāpēs }\end{array}$} & $\mathrm{Jā}(\mathrm{n}=58)$ & 36,71 & 11,83 & \multirow{2}{*}{8,07} & \multirow{2}{*}{0,005} \\
\hline & $\mathrm{Ne}(\mathrm{n}=182)$ & 31,09 & 10,35 & & \\
\hline \multirow{2}{*}{$\begin{array}{l}\text { Stāsta par savu pieredzi pie } \\
\text { zobārsta }\end{array}$} & $\mathrm{Jā}(\mathrm{n}=63)$ & 35,24 & 10,74 & \multirow{2}{*}{4,90} & \multirow{2}{*}{0,028} \\
\hline & $\mathrm{Ne}(\mathrm{n}=177)$ & 31,46 & 10,91 & & \\
\hline \multirow{2}{*}{$\begin{array}{l}\text { Nem bērnu līdz, ejot pie sava } \\
\text { zobārsta }\end{array}$} & $\mathrm{Jà}(\mathrm{n}=32)$ & 35,66 & 13,92 & \multirow{2}{*}{3,13} & \multirow{2}{*}{0,078} \\
\hline & $\mathrm{Ne}(\mathrm{n}=208)$ & 31,96 & 10,39 & & \\
\hline \multirow{2}{*}{$\begin{array}{l}\text { Apsola balvu par labu } \\
\text { uzvešanos pie zobārsta }\end{array}$} & $\mathrm{Jā}(\mathrm{n}=45)$ & 38,02 & 11,46 & \multirow{2}{*}{10,57} & \multirow{2}{*}{0,001} \\
\hline & $\mathrm{Ne \overline { } ( \mathrm { n } = 1 9 5 )}$ & 31,16 & 10,46 & & \\
\hline \multirow{2}{*}{ Nekā īpaši negatavo } & $\mathrm{Jā}(\mathrm{n}=60)$ & 28,03 & 7,71 & \multirow{2}{*}{9,03} & \multirow{2}{*}{0,003} \\
\hline & $\mathrm{Ne}(\mathrm{n}=180)$ & 33,92 & 11,50 & & \\
\hline Cits variants & $\mathrm{Jā}(\mathrm{n}=35)$ & 31,54 & 12,00 & 0,15 & 0,701 \\
\hline
\end{tabular}

Bērniem, kuru vecāki mierina, ka „zobārsts neko nedarīs un nekas nesāpēs”, stāsta par savu pieredzi pie zobārsta un apsola balvu par labu uzvešanos pie zobārsta, bija statistiski augstāks baiļu līmenis nekā vecākiem, kas šādi bērnus nesagatavo (skat. 3.13. tabulu). Statistiski nozīmīgi zemāks baiḷu līmenis bija bērniem, kurus vecāki nekā īpaši negatavo pirms zobārsta apmeklējuma. Citos atbilžu variantos (lasa bērnu grāmatas par zobu ārstēšanu, 
ņem bērnu līdzi pie zobārsta) bērnu baiļu līmenis neatšķīrās statistiski nozīmīgi. Visi aprēķini tika veikti, ņemot vērā bērnu vecumu (vecums bija kovariatīvais mainīgais).

\subsubsection{Saistība ar bērnu zobu kopšanas paradumiem un attieksmi}

Bērnu bailēm no zobārsta bija statistiski nozīmīga pozitīva korelācija ar faktu, ka bērns uztver zobu tīrīšanu kā pienākumu $(r=0,19, \mathrm{p}=0,004)$ vai atsakās no zobu tīrīšanas pat pieaugušo uzraudzībā $(r=0,13, p=0,049)$ (skat. 3.14. tabulu).

3.14. tabula

Bērnu baiḷu no zobārsta saistība ar bērnu zobu kopšanas paradumiem un attieksmi

\begin{tabular}{|c|c|c|}
\hline Bērnu zobu kopšanas paradumi un attieksme & $\begin{array}{l}\text { Pīrsona korelācija ar bērnu } \\
\text { bailēm no zobārsta (r) }\end{array}$ & p vērtība \\
\hline Zobu tīrīšanas regularitāte & 0,05 & 0,470 \\
\hline Uztver zobu tīrīšanu kā pašsaprotamu & $-0,14$ & 0,031 \\
\hline Uztver zobu tīrīšanu kā pienākumu & 0,19 & 0,004 \\
\hline Izvairās no zobu tīrīšanas & $-0,11$ & 0,088 \\
\hline Atsakās tīrìt zobus, bet tīra pieaugušo uzraudzībā & 0,07 & 0,310 \\
\hline Atsakās tīrīt zobus pat pieaugušo uzraudzībā & 0,13 & 0,049 \\
\hline Vecāki pārbauda zobus pēc tīrīšanas & 0,07 & 0,315 \\
\hline
\end{tabular}

Tāpat tika konstatēta statistiski ticama negatīva korelācija bērnu bailēm no zobārsta un bērnu zobu tīrī̌šnu kā pašsaprotamu lietu $(r=-0,14, \mathrm{p}=0,031)$ (skat. 3.14. tabulu). Tas nozīmē, ka bērni, kuri nelabprāt tīra zobus, vairāk baidās no zobārsta.

\subsubsection{Saistība ar bērnu personības un uzvedības faktoriem}

Bērnu bailēm no zobārsta bija statistiski nozīmīga korelācija ar bērna uzvedību zobārsta kabinetā $(\mathrm{r}=-0,69, \mathrm{p}<0,001)$, kā arī statistiski nozīmīga korelācija ar bērna vispārējo trauksmi jeb satraucamību $(r=0,50, p=0,005)$, emocionalitāti $(r=0,18, p=0,005)$ un spēju pašam nomierināties $(\mathrm{r}=-0,27, \mathrm{p}<0,001)$. Tas nozīmē, jo izteiktākas bija bērnu bailes no zobārsta, jo negatīvāka bija viņu uzvedība zobārsta kabinetā, bērns vairāk satraucas dažādās situācijās ar̄̄ ārpus zobārsta, mazāk spēj pats nomierināties un jo spilgtākas ir bērna emociju izpausmes. Tāpat bija arī statistiski nozīmīga bērna baiļu no zobārsta korelācija ar bērna pārdzìvojumu ilgumu un bailēm no zirnekḷiem un kukainiem (skat. 3.15. tabulu). Tomēr bailēm no zobārsta nebija saistības ar bērna sabiedriskumu, aktivitātes līmeni, labilitāti, kautrīgumu, bailēm no palikšanas vienam vai no svešiem cilvēkiem, ne arī ar baiļu skaitu. 
3.15. tabula

Bērnu baiḷu no zobārsta saistība ar bērnu personības un uzvedības faktoriem

\begin{tabular}{|l|c|c|}
\hline Bērnu personības un uzvedības faktori & $\begin{array}{c}\text { Pīrsona korelācija ar bērnu } \\
\text { bailēm no zobārsta (r) }\end{array}$ & p vērtība \\
\hline Sabiedriskums & $-0,02$ & 0,758 \\
\hline Aktivitāte & $-0,06$ & 0,356 \\
\hline Impulsivitāte & $-0,05$ & 0,483 \\
\hline Labilitāte & 0,09 & 0,178 \\
\hline Emocionalitāte & 0,18 & 0,005 \\
\hline Kautrīgums & $-0,08$ & 0,198 \\
\hline Satraucamība (vispārējā trauksme) & 0,50 & 0,005 \\
\hline Spēja pašam nomierināties & $-0,27$ & 0,000 \\
\hline Pārdz̄ivojuma ilgums & 0,15 & 0,021 \\
\hline Bailes no augstuma & $-0,01$ & 0,889 \\
\hline Bailes no slēgtām telpām & 0,11 & 0,097 \\
\hline Bailes no palikšanas vienam & 0,06 & 0,329 \\
\hline Bailes no zirnekḷiem/kukainiem & 0,13 & 0,044 \\
\hline Bailes no nepazistamiem dzīvniekiem & $-0,01$ & 0,881 \\
\hline Bailes no tumsas & 0,05 & 0,452 \\
\hline Bailes no svešiem cilvēkiem & 0,02 & 0,731 \\
\hline Bail̦u daudzums (skaits) & 0,11 & 0,105 \\
\hline Uzvedība pie zobārsta (Frankla skala) & $-0,69$ & 0,000 \\
\hline
\end{tabular}

\subsubsection{Saistība ar gimenes stresa faktoriem}

$\mathrm{Ne}$ vecāku personiskajiem, ne ǵimenes, ne darba stresa faktoriem nebija statistiski nozīmīgas saistības ne ar bērna bailēm no zobārsta, ne mutes dobuma veselību. Šādas saistības nebija arī stresa faktoru daudzumam (summai) (skat. 3.16. tabulu).

Bērnu baiḷu no zobārsta saistība ar gimenes stresa faktoriem

3.16. tabula

\begin{tabular}{|l|c|c|}
\hline Ģimenes stresa faktori & $\begin{array}{c}\text { Pīrsona korelācija ar bērnu } \\
\text { bailēm no zobārsta (r) }\end{array}$ & p vērtība \\
\hline G̦imenes stresa faktori: & & \\
\hline - kāda ğimenes locekḷa pārvākšanās & 0,10 & 0,104 \\
\hline - veselības problēmas kādam no ǵimenes locekḷiem & 0,06 & 0,330 \\
\hline Personiskā stresa faktori: & & \\
\hline - tuva drauga nāve/šk̆iršanās & 0,09 & 0,154 \\
\hline - nepatikšanas ar varasiestādēm & $-0,07$ & 0,282 \\
\hline Darba stresa faktori: & & \\
\hline - pārmainnas karjerā & 0,10 & 0,108 \\
\hline - pārmaiņas darba nosacījumos & 0,10 & 0,108 \\
\hline Stresa faktoru summa & & \\
\hline
\end{tabular}




\subsubsection{BTZ bērniem ar un bez negatīvas pieredzes pie zobārsta}

Pārbaudot atšķirības bērnu baiļu līmenī atkarībā no negatīvas pieredzes, grupai ar negatīvu pieredzi pie zobārsta bija statistiski nozīmīgi augstāks vidējais baiḷu līmenis $(M=36,67, S D=10,86, \mathrm{n}=91)$ nekā grupai bez negatīvas pieredzes pie zobārsta $(M=29,93$, $S D=10,25, \mathrm{n}=148)$, ANOVA $F=23,31, \mathrm{p}<0,001)$.

\subsubsection{Baiḷu no zobārsta un psihosociālo faktoru regresijas analīze}

Pêtîjuma noslēgumā bērnu baiļu no zobārsta saistība ar dažādiem psihosociāliem faktoriem tika pārbaudīta ar lineārās regresijas palīdzību.

Pārbaudot sociālekonomisko/sociāldemogrāfisko faktoru spēju izskaidrot bērnu baiḷu no zobārsta variāciju, tika veikta vairāksoḷu regresijas analīze un konstatēts, ka bērnu bailes no zobārsta visvairāk prognozē KPE $(\beta=0,24, \mathrm{p}=0,001)$, kā arī negatīvā veidā - bērnu skaits $(\beta=-0,15, p=0,034)$ un mātes vecums $(\beta=-0,15, p=0,039)$. Tas nozīmēe jo bērnam ir vairāk kariozu, plombētu vai ekstrahētu zobu un jo mazāk brāļu vai māsu, un jo jaunāka ir mamma, jo lielāka ir iespēja, ka bērnam būs bailes no zobārsta (skat. 3.17. tabulu). Saistībā ar sociālekonomiskajiem/sociāldemogrāfiskajiem faktoriem bērna vecums neprognozēja bērna bailes no zobārsta statistiski nozīmīgi. Kopumā sociālekonomiskie faktori izskaidroja 15\% $\left(\mathrm{R}^{2}=0,15, \mathrm{p}<0,001\right)$ bērnu baiḷu no zobārsta variācijas regresijas analīzes 4 . solī.

3.17. tabula

Vairāksoḷu regresijas analīze sociālekonomiskajiem/sociāldemogrāfiskajiem faktoriem, kas prognozē bērnu bailes no zobārsta (4.solis)

\begin{tabular}{|l|r|r|r|r|r|c|}
\hline Sociālekonomiskie faktori & \multicolumn{1}{|c|}{$\mathrm{B}$} & $\mathrm{SE}$ & $\mathrm{Beta}(\beta)$ & \multicolumn{1}{c|}{$\mathrm{t}$} & $\mathrm{p}$ vērtība & $\mathrm{R}^{2}$ \\
\hline Konstante & \multicolumn{1}{|c|}{5,66} & 5,36 & & 8,89 & 0,000 & 0,15 \\
\hline Vecums & $-0,52$ & 0,32 & $-0,12$ & $-1,63$ & 0,104 & \\
\hline KPE & 0,75 & 0,22 & 0,24 & 3,38 & 0,001 & \\
\hline Bērnu skaits & $-2,57$ & 1,20 & $-0,15$ & $-2,14$ & 0,034 & \\
\hline Mātes vecums & $-0,29$ & $-0,14$ & $-0,15$ & $-2,08$ & 0,039 & \\
\hline
\end{tabular}

Pārbaudot vairāksoḷu regresijas analīzē bērnu medicīniskās pieredzes faktoru spēju izskaidrot bērnu baiļu no zobārsta variāciju, tika konstatēts, ka bērnu bailes no zobārsta visvairāk prognozē bērna bailīga $(\beta=0,43, \mathrm{p}<0,001)$ vai piesardz̄̄ga $(\beta=0,29, \mathrm{p}<0,001)$ attieksme pret ārstiem, izņemot zobārstus, kā arī KPE $(\beta=0,17, p=0,002)$ un apgrieztā veidā - bērna vecums $(\beta=-0,14, p=0,012)$ (skat. 3.18. tabulu). Tas nozīmē, ka mazākiem bērniem ar bailīgu un piesardzīgu attieksmi pret ārstiem, izṇemot zobārstus, un augstāku kariesa intensitāti būs lielākas bailes no zobārsta. Kopumā bērna medicīniskās pieredzes 
faktori izskaidroja 34\% $\left(\mathrm{R}^{2}=0,34, \mathrm{p}<0,001\right)$ bērnu baiḷu no zobārsta variācijas regresijas analīzes 4. solī.

Vairāksoḷu regresijas analīze bērnu medicīniskās pieredzes faktoriem, 3.18. tabula kas prognozē bērnu bailes no zobārsta (4. solis)

\begin{tabular}{|l|r|c|r|r|c|c|}
\hline $\begin{array}{l}\text { Bērnu medicīniskās pieredzes un } \\
\text { attieksmes faktori }\end{array}$ & B & SE & Beta $(\beta)$ & $\mathrm{t}$ & $\mathrm{p}$ vērtība & $\mathrm{R}^{2}$ \\
\hline Konstante & 29,79 & 2,39 & & 12,42 & 0,003 & 0,34 \\
\hline Vecums & $-0,57$ & 0,23 & $-0,14$ & $-2,53$ & 0,012 & \\
\hline KPE & 0,53 & 0,17 & 0,17 & 3,15 & 0,002 & \\
\hline Bailīga attieksme pret ārstu & 16,27 & 2,08 & 0,43 & 7,81 & 0,000 & \\
\hline Piesardzīga attieksme pret ārstu & 6,94 & 1,27 & 0,29 & 5,47 & 0,000 & \\
\hline
\end{tabular}

Pārbaudot vairāksoḷu regresijas analīzē bērnu zobārstniecības pieredzes faktoru spēju izskaidrot baiḷu no zobārsta variāciju, vispirms tika konstatēts, ka bērnu bailes no zobārsta visvairāk prognozē bērnu bailes un raudāšana, ejot pie zobārsta $(\beta=0,49, \mathrm{p}<0,001)$ un zobu ārstēšanas procesa norise ar grūtībām $(\beta=0,25, \mathrm{p}=0,006)$, bet ne KPE un vecums (skat. 3.19. tabulu). Tas nozīmēe, ka bērna raudāšana ejot pie zobārsta un iepriekšēja zobu ārstēšanas norise ar grūtībām norāda uz lielākām bērna bailēm no zobārsta. Šis modelis saistībā ar bērna zobārstniecības pieredzes faktoriem izskaidroja $56 \%\left(\mathrm{R}^{2}=0,56, \mathrm{p}<0,001\right)$ bērnu baiḷ no zobārsta variācijas regresijas analīzes 4 . solī.

3.19. tabula

Vairāksoḷu regresijas analīze bērnu zobārstniecības pieredzes faktoriem, kas prognozē bērnu bailes no zobārsta (4. solis, 1. modelis)

\begin{tabular}{|l|r|r|r|r|r|c|}
\hline $\begin{array}{l}\text { Bērnu zobārstniecības pieredzes un } \\
\text { attieksmes faktori }\end{array}$ & B & SE & Beta( $\beta)$ & $\mathrm{t}$ & p vērtība & $\mathrm{R}^{2}$ \\
\hline Konstante & 26,74 & 3,78 & & 7,07 & 0,000 & 0,56 \\
\hline Vecums & $-0,48$ & 0,23 & $-0,13$ & $-1,64$ & 0,105 & \\
\hline KPE & 0,39 & 0,24 & 0,13 & 1,68 & 0,097 & \\
\hline Bailes un raudāšana, ejot pie zobārsta & 10,59 & 1,83 & 0,49 & 5,79 & 0,000 & \\
\hline $\begin{array}{l}\text { Zobu ārstēšanas procesa norise ar } \\
\text { grūtībām }\end{array}$ & 2,06 & 0,73 & 0,25 & 2,81 & 0,006 & \\
\hline
\end{tabular}

Savukārt, no 1. modeḷa izslēdzot faktoru „bailes un raudāšana, ejot pie zobārsta”, kā visnozīmīgākie faktori parādījās zobu ārstēšanas procesa norise ar grūtībām $(\beta=0,43$, $p<0,001)$ un negatīvā veidā - bērna vecums $(\beta=-0,18, p=0,047)$ un bērna neitrāla attieksme, ejot pie zobārsta $(\beta=-0,17, p=0,049)$ (skat. 3.20. tabulu). Tātad, jaunākiem bērniem ar izteiktākām grūtībām zobu ārstēšanas procesā ir lielākas bērna bailes no zobārsta. Otrais modelis saistībā ar bērnu zobārstniecības pieredzes faktoriem izskaidroja 41\% $\left(\mathrm{R}^{2}=0,41, \mathrm{p}<0,001\right)$ baiḷu no zobārsta variācijas 4 . solī. 
Vairāksoḷu regresijas analīze bērnu zobārstniecības pieredzes faktoriem, kas prognozē bērnu bailes no zobārsta (4. solis, 2. modelis)

\begin{tabular}{|l|r|r|r|r|r|c|}
\hline $\begin{array}{l}\text { Bērnu zobārstniecības pieredzes un } \\
\text { attieksmes faktori }\end{array}$ & B & SE & Beta $(\beta)$ & t & p vērtība & $\mathrm{R}^{2}$ \\
\hline Konstante & 27,43 & 4,39 & & 6,24 & 0,000 & 0,41 \\
\hline Vecums & $-0,68$ & 0,34 & $-0,18$ & $-2,01$ & 0,047 & \\
\hline KPE & 0,46 & 0,27 & 0,15 & 1,69 & 0,094 & \\
\hline $\begin{array}{l}\text { Zobu ārstēšanas procesa norise ar } \\
\text { grūtībām }\end{array}$ & 3,54 & 0,79 & 0,43 & 4,49 & 0,000 & \\
\hline Neitrāla attieksme, ejot pie zobārsta & $-5,44$ & 2,73 & $-0,17$ & $-1,99$ & 0,049 & \\
\hline
\end{tabular}

No 2. modeļa izslēdzot faktoru „zobu ārstēšanas procesa norise ar grūtībām”, kā visnozīmīgākie faktori parādījās panika vai histērija, ejot pie zobārsta $(\beta=0,29, p=0,003)$, un apgrieztā veidā - bērna vecums $(\beta=-0,31, \mathrm{p}=0,001)$ un iepriekš veikta zobu higiēna $(\beta=-0,24, p=0,012)$ (skat. 3.21. tabulu). Tātad, mazākiem bērniem un tiem, kam ejot pie zobārsta viņam parādās panika vai histērija un kam iepriekš nav veikta zobu higiēna, ir lielākas bailes no zobārsta. Trešais modelis saistībā ar bērnu zobārstniecības pieredzes faktoriem izskaidroja $33 \%\left(\mathrm{R}^{2}=0,33, \mathrm{p}<0,001\right)$ baiļu no zobārsta variācijas 4 . solī. Bērna negatīvā pieredze pie zobārsta neparādījās kā nozīmīgs faktors, kas prognozē bērna bailes no zobārsta.

3.21. tabula

Vairāksoḷu regresijas analīze bērnu zobārstniecības pieredzes faktoriem, kas prognozē bērnu bailes no zobārsta (4. solis, 3. modelis)

\begin{tabular}{|l|r|r|r|r|r|c|}
\hline $\begin{array}{l}\text { Bērnu zobārstniecības pieredzes un } \\
\text { attieksmes faktori }\end{array}$ & B & SE & Beta $(\beta)$ & t & p vērtība & $\mathrm{R}^{2}$ \\
\hline Konstante & 45,82 & 4,49 & & 10,21 & 0,000 & 0,33 \\
\hline Vecums & $-1,23$ & 0,36 & $-0,31$ & $-3,43$ & 0,001 & \\
\hline KPE & 0,49 & 0,31 & 0,15 & 1,59 & 0,116 & \\
\hline Panika / histērija, ejot pie zobārsta & 11,00 & 3,65 & 0,29 & 3,01 & 0,003 & \\
\hline Veikta zobu higiēna & $-5,92$ & 2,29 & $-0,24$ & $-2,57$ & 0,012 & \\
\hline
\end{tabular}

Pārbaudot vecāku un informācijas faktoru saistību ar bailēm no zobārsta vairāksoḷu regresijas analīzē, tika konstatēts, ka bērnu bailes no zobārsta visvairāk prognozē KPE $(\beta=0,20, p=0,001)$, vecāku bailes no zobārsta $(\beta=0,17, p=0,003)$ un vecāku stāsti par savu pieredzi pie zobārsta $(\beta=0,18, \mathrm{p}=0,002)$. Tāpat bērnu bailes no zobārsta lielā mērā prognozē arī teikšana, lai neuztraucas pirms svarīgiem notikumiem $(\beta=0,16, p=0,007)$, balvas apsolīšana par labu uzvedību pie zobārsta $(\beta=0,15, \mathrm{p}=0,009)$ un negatīvā veidā $-\mathrm{ka}$ saņem informāciju par zobu kopšanu no zobārsta $(\beta=-0,16, p=0,006)$ (skat. 3.22. tabulu). Mazāk par iepriekš minētajiem faktoriem, bet arī statistiski nozīmīgi bērna bailes no zobārsta 
prognozē arī negatīvā veidā bērna vecums $(\beta=-0,13, \mathrm{p}=0,029)$, tas, ka vecāki saņem informāciju par zobu kopšanu no zobu higiēnista $(\beta=-0,12, p=0,032)$ un ka bērnu pie zobārsta pavada cilvēks, kuram ir laiks $(\beta=-0,12, p=0,044)$. Nelielā mērā bailes no zobārsta prognozē arī tas, ka bērnu pie zobārsta pavada tas, kuru bērns klausa $(\beta=0,11$, $\mathrm{p}=0,049)$. Tas nozīmēe, ka tiem vecākiem, kas baidās no zobārsta, stāsta par savu pieredzi pie zobārsta un saka, lai bērns neuztraucas un sola balvu par labu uzvedību pie zobārsta, būs izteiktākas bērna bailes no zobārsta. Savukārt, vecākiem bērniem un tiem, kam vecāki saņem informāciju par zobu kopšanu no zobārstiem vai zobu higiēnistiem, būs mazākas bailes no zobārsta. Kopumā vecāku un informācijas faktori prognozē $30,8 \%\left(\mathrm{R}^{2}=0,31, \mathrm{p}<0,001\right)$ baiḷu no zobārsta variācijas 10 .solī.

3.22. tabula

Vairāksoḷu regresijas analīze vecāku un informācijas faktoriem, kas prognozē bērnu bailes no zobārsta (10. solis)

\begin{tabular}{|l|r|r|r|r|r|c|}
\hline Vecāku un informācijas faktori & \multicolumn{1}{|c|}{$\mathrm{B}$} & \multicolumn{1}{c|}{$\mathrm{SE}$} & Beta $(\beta)$ & \multicolumn{1}{c|}{$\mathrm{t}$} & $\mathrm{p}$ vērtība & $\mathrm{R}^{2}$ \\
\hline Konstante & 29,58 & \multicolumn{1}{c}{3,33} & & 8,89 & 0,000 & 0,31 \\
\hline Vecums & $-0,53$ & 0,24 & $-0,13$ & $-2,19$ & 0,029 & \\
\hline KPE & 0,61 & 0,18 & 0,20 & 3,49 & 0,001 & \\
\hline Vecāku bailes no zobārsta & 0,54 & 0,18 & 0,17 & 3,02 & 0,003 & \\
\hline $\begin{array}{c}\text { Stāsta par savu pieredzi pie } \\
\text { zobārsta }\end{array}$ & 4,34 & 1,39 & 0,18 & 3,13 & 0,002 & \\
\hline $\begin{array}{c}\text { Sañem informāciju par zobu } \\
\text { kopšanu no zobārsta }\end{array}$ & $-4,17$ & 1,52 & $-0,16$ & $-2,75$ & 0,006 & \\
\hline $\begin{array}{c}\text { Saka, lai neuztraucas pirms } \\
\text { svarīgiem pasākumiem }\end{array}$ & 3,81 & 1,40 & 0,16 & $-2,72$ & 0,007 & \\
\hline Pavada cilvēks, kuram ir laiks & $-2,63$ & 1,29 & $-0,12$ & $-2,03$ & 0,044 & \\
\hline $\begin{array}{c}\text { Apsola balvu par labu uzvedību } \\
\text { pie zobārsta }\end{array}$ & 4,21 & 1,61 & 0,15 & 2,62 & 0,009 & \\
\hline $\begin{array}{c}\text { Saņem informāciju par zobu } \\
\text { kopšanu no zobu higiēnista }\end{array}$ & $-2,69$ & 1,25 & $-0,12$ & $-2,16$ & 0,032 & \\
\hline Pavada cilvēks, ko bērns klausa & 9,66 & 4,75 & 0,11 & 2,04 & 0,043 & \\
\hline
\end{tabular}

Pārbaudot vairāksoḷu regresijas analīzē bērnu zobu kopšanas paradumu spēju izskaidrot bērnu baiļu no zobārsta variāciju, tika konstatēts, ka bērnu bailes no zobārsta visvairāk prognozē KPE $(\beta=0,23, \mathrm{p}<0,001)$ un tas, ka uztver zobu tīrī̌sanu kā pienākumu $(\beta=0,162, p=0,008)$, kā arī negatīvā veidā - bērna vecums $(\beta=-0,19, p=0,002)$ (skat. 3.23. tabulu). Tas nozīmēe, jo vairāk kariozu, plombētu un ekstrahētu zobu un jo jaunāks ir bērns, un vairāk uztver zobu tīrīšanu kā pienākumu, jo lielākas ir bailes no zobārsta. Kopumā zobu tīrīšanas paradumu bloks izskaidro $14 \%\left(\mathrm{R}^{2}=0,14\right.$, $\left.\mathrm{p}<0,001\right)$ baiḷu no zobārsta variācijas 3. solī. 
Vairāksoḷu regresijas analīze bērnu zobu kopšanas paradumiem, kas prognozē bērnu bailes no zobārsta (3.solis)

\begin{tabular}{|l|r|r|r|r|r|c|}
\hline Zobu kopšanas paradumi & \multicolumn{1}{|c|}{ B } & \multicolumn{1}{c|}{ SE } & Beta $(\beta)$ & \multicolumn{1}{c|}{$\mathrm{t}$} & p vērtība & \multicolumn{1}{c|}{$\mathrm{R}^{2}$} \\
\hline Konstante & 32,85 & 2,68 & & 12,25 & 0,000 & 0,14 \\
\hline Vecums & $-0,81$ & 0,26 & $-0,19$ & $-3,15$ & 0,002 & \\
\hline KPE & 0,71 & 0,19 & 0,23 & 3,78 & 0,000 & \\
\hline Uztver zobu tīrı̌šanu kā pienākumu & 3,76 & 1,41 & 0,16 & 2,67 & 0,008 & \\
\hline
\end{tabular}

Pārbaudot vairāksoḷu regresijas analīzē bērnu personības un uzvedības faktoru spēju izskaidrot bailes no zobārsta, vispirms tika konstatēts, ka bērnu bailes no zobārsta visvairāk prognozē bērna uzvedība zobārsta krēslā $(\beta=-0,56, p<0,001)$ un vispārējā trauksme jeb satraucamība $(\beta=-0,24, p<0,001)$ (negatīvais koeficients saistīts ar pretēju vērtējuma skalu). Tāpat bērna bailes no zobārsta statistiski nozīmīgi prognozē arī bērna satraukuma jeb pārdzīvojuma ilgums $(\beta=0,11, p=0,016)$ un KPE $(\beta=0,09, p=0,051)$, savukārt vecumam šajā modelī nebija statistiski nozīmīga ietekme (skat. 3.24. tabulu).

3.24. tabula

Vairāksoḷu regresijas analīze bērnu personības un uzvedības faktoriem, kas prognozē bērnu bailes no zobārsta (5.solis, 1. modelis)

\begin{tabular}{|l|r|r|r|r|r|c|}
\hline Personības un uzvedības faktori & \multicolumn{1}{c|}{ B } & \multicolumn{1}{c|}{ SE } & Beta $(\beta)$ & \multicolumn{1}{c|}{ t } & p vērtība & $\mathrm{R}^{2}$ \\
\hline Konstante & 55,99 & 2,82 & & 19,87 & 0,000 & 0,54 \\
\hline Vecums & 0,01 & 0,20 & 0,00 & 0,06 & 0,950 & \\
\hline KPE & 0,28 & 0,14 & 0,09 & 0,09 & 0,051 & \\
\hline Bērna uzvedība zobārsta krēslā & $-7,44$ & 0,69 & $-0,56$ & $-10,67$ & 0,000 & \\
\hline Vispārējā trauksme & $-3,35$ & 0,68 & $-0,24$ & $-4,93$ & 0,000 & \\
\hline Satraukuma ilgums & 1,21 & 0,49 & 0,11 & 2,43 & 0,016 & \\
\hline
\end{tabular}

Tas nozīmēe bērnam, kas slikti uzvedas zobārsta krēslā un vairāk satraucas (arī ārpus zobārsta kabineta), kā arī ilgāk pārdzīvo, paredzamas lielākas bailes no zobārsta. Kopumā šajā modelī bērnu personības un uzvedības faktori izskaidroja $54 \%\left(\mathrm{R}^{2}=0,54, \mathrm{p}<0,001\right)$ baiḷ no zobārsta variācijas 5. solī.

Savukārt, izslēdzot no 1.modeḷa faktoru „bērna uzvedība zobārsta krēslā”, tika konstatēts, ka bērnu bailes no zobārsta visvairāk prognozē bērna vispārējā trauksme jeb satraucamība $(\beta=-0,44, \mathrm{p}<0,001)$ (negatīvais koeficients saistīts ar pretēju vērtējuma skalu). Tāpat bērna bailes no zobārsta statistiski nozīmīgi prognozē arī bērna $\operatorname{KPE}(\beta=0,18$, $\mathrm{p}=0,002)$, apgrieztā veidā - vecums $(\beta=-0,17, \mathrm{p}=0,003), \mathrm{ka}$ arī bailes no zirnekḷiem/kukaiņiem $(\beta=0,12, \mathrm{p}=0,033)$ (skat. 3.25. tabulu). Tas nozīmē, ka mazākam bērnam, kas satraucas arī ārpus zobārsta kabineta, tai skaitā, redzot zirnekḷus un/vai kukaiņus, ar augstāku kariesa intensitāti būs lielākas bailes no zobārsta. Kopumā otrajā modelī bērnu 
personības un uzvedības faktori izskaidroja vairs tikai 33\% $\left(\mathrm{R}^{2}=0,33, \mathrm{p}<0,001\right)$ baiļu no zobārsta variācijas 4.solī.

3.25. tabula

Vairāksoḷu regresijas analīze bērnu personības un uzvedības faktoriem, kas prognozē bērnu bailes no zobārsta (4. solis, 2. modelis)

\begin{tabular}{|l|r|r|r|r|r|c|}
\hline Bērnu personības un uzvedības faktori & \multicolumn{1}{c|}{ B } & \multicolumn{1}{c|}{ SE } & Beta $(\beta)$ & \multicolumn{1}{c|}{$\mathrm{t}$} & p vērtība & $\mathrm{R}^{2}$ \\
\hline Konstante & \multicolumn{1}{|c}{26,79} & 2,89 & & 16,17 & 0,000 & 0,33 \\
\hline Vecums & $-0,71$ & 0,23 & $-0,17$ & $-3,05$ & 0,003 & \\
\hline KPE & 0,54 & 0,17 & 0,18 & 3,18 & 0,002 & \\
\hline Vispārējā trauksme & $-6,11$ & 0,77 & $-0,44$ & $-8,05$ & 0,000 & \\
\hline Bailes no zirnekḷiem/kukainiem & 2,69 & 1,25 & 0,12 & 2,15 & 0,033 & \\
\hline
\end{tabular}

Pārbaudot baiḷu no zobārsta saistību ar dažādiem psihosociāliem faktoriem ar lineāro regresiju palīdzību, tika konstatēts, ka visvairāk bailes no zobārsta izskaidro bērna zobārstniecības pieredzes un attieksmes faktori $\left(\mathrm{R}^{2}=56 \%\right)$ un personības faktori $\left(\mathrm{R}^{2}=54 \%\right)$. Nedaudz mazāk bailes no zobārsta izskaidro vecāku un informācijas faktori, kā arī bērna medicīniskā pieredze un attieksme (attiecīgi $\mathrm{R}^{2}=31 \%$ un 34\%). Savukārt sociālekonomiskie faktori un zobu kopšanas paradumi bailes no zobārsta izskaidroja pavisam nelielā mērā (attiecīgi $\mathrm{R}^{2}=15 \%$ un $14 \%$ ). Ģimenes stresa faktori bērnu bailes no zobārsta neizskaidroja (sk. 3.17. attēlu). 


\section{Sociālekonomiskie faktori}

- Vecums

- KPE

- Bērnu skaits

- Mātes vecums

Bērnu medicīniskās pieredzes faktori un attieksme

- Vecums

- KPE

- Bailīga attieksme pret ārstu

- Piesardzīga attieksme pret ārstu

Bērnu zobārstniecības pieredzes faktori

- Vecums

- KPE

- Bailes un raudāšana, ejot pie zobārsta

- Zobu ārstēšanas procesa norise ar grūtībām

Vecāku un informācijas faktori

- Vecums

- KPE

- Vecāku bailes no zobārsta

- Stāsta par savu pieredzi pie zobārsta

- Sañem informāciju par zobu kopšanu no zobārsta

- Saka, lai neuztraucas pirms svarīgiem pasākumiem

- Pavada cilvēks, kuram ir laiks

- Apsola balvu par labu uzvedíbu pie zobārsta

- Sañem informāciju par zobu kopšanu no zobu higiēnista

- Pavada cilvēks, ko bērns klausa

\section{Bērnu zobu kopšanas paradumi un attieksme}

- Vecums

- KPE

- Uztver zobu tīī̌šanu kā pienākumu

Bērnu personības un uzvedības faktori

- Vecums

- KPE

- Bērna uzvedíba zobārsta krēslā

- Vispārējā trauksme

- Satraukuma ilgums

3.17. attēls. Regresijas modeḷu apkopojums bērnu baiḷu no zobārsta variāciju izskaidrojošiem faktoriem (kontrolējot vecumu un KPE) 


\section{DISKUSIJA}

Diskusijā uzsvērti pētījuma galvenie rezultāti un salīdzinošs to izvērtējums, atzīmēta to novitāte, aplūkoti to ierobežojumi un izlases atlases ietekme. Bailes no zobārsta ir multifaktoriāla problēma, tāpēc joprojām turpinās visdažādākie pētījumi un diskusijas, cik liela nozīme to izcelsmē ir cilvēka iekšējiem faktoriem (kâa vecums, dzimums un temperaments), bet cik - ārējiem faktoriem (ǵimenes attieksmei, sociālekonomiskajiem faktoriem un zobārstniecības personāla attieksmei). Ir atsevišķi jautājumi, kas ir publicēti metaanalīzēs un par ko diskusijas vairs nenotiek, piemēram, bailes no zobārsta caurmērā ir lielākas jaunākiem bērniem (Klingberg \& Broberg, 2007), un bērnu BTZ vismaz līdz 8 gadu vecumam lielā mērā ir saistītas ar vecāku bailēm un trauksmi zobārstniecīiā (Themessl-Huber et al., 2010). Tajā pašā laikā pasaulē maz ir pētīts, cik liela nozīme ir bērna vecumam pirmās ārstēšanas pieredzes laikā un kā bērnu bailes ietekmē vecāku teiktais pirms zobārsta vizītes. Tāpat ir veikti lineārās regresijas pētījumi par dažādu faktoru ieguldījumu baiḷu no zobārsta izskaidrošanā, bet pārsvarā tie aptver nelielu mainīgo skaitu, kas neraksturo visu ar BTZ saistīto faktoru spektru. Latvijā nav veikti pētījumi par bailēm no zobārsta ne pieaugušajiem, ne bērniem. Nav veikti arī pētījumi par Latvijas kultūrvēsturisko vidi zobārstniecības aspektā, kas apgrūtina diskusiju.

\subsection{CFSS-DS ticamība un validitāte}

CFSS-DS aptauja pētījumā parādīja augstu ticamību un validitāti. CFSS-DS ir pētījumos ļoti bieži izmantota aptauja baiḷu no zobārsta novērtēšanai pirmsskolas un jaunākā skolas vecuma bērniem, kas adaptēta visdažādākajās valodās un ir ar augstu ticamību (Kronbaha alfa bija no 0,83 līdz 0,93) (Alvesalo et.al., 1993; Milgrom et al., 1994; ten Berge et al., 1998; ten Berge et al., 2002; Majstorovič et al., 2003, Arapostathis et al., 2008). CFSSDS parādīja arī vērā ņemamu konverğento validitāti, līdzīgi kā citos pêtījumos (Cuthbert \& Melamed, 1982; Majstorovič et al., 2003).

\subsection{BTZ saistība ar bērnu iekšējiem faktoriem}

Šajā diskusijas daḷā tiks apspriestas bērnu bailes no zobārsta un to saistība ar bērna iekšējiem (personības un uzvedības) faktoriem - vecumu, dzimumu, temperamenta iezīmēm (aktivitāti, emocionalitāti un kautrīgumu), vispārējo trauksmi, ar zobārstniecību nesaistītu baiḷu skaitu un uzvedību zobārstniecības situācijā. 


\subsubsection{BTZ saistība ar bērnu vecumu}

Bērnu vecumam tika konstatēta negatīva statistiski nozīmīga korelācija ar bērnu bailēm un trauksmi zobārstniecībā, tas ir, caurmērā jaunākiem bērniem bija izteiktākas bailes no zobārsta, savukārt vecākiem bērniem - mazāk izteiktas. Tomēr vieni no zemākajiem baiļu rādītājiem bija bērniem 6 gadu vecumā, savukārt vieni no augstākajiem - bērniem 11 gadu vecumā. Kopumā sakarību rezultāti saskanēja ar lielāko daļu pētījumu, kuros konstatēts, ka bērniem vecumposmā no 4 līdz 14 gadiem pakāpeniski samazinās vidējais baiḷu no zobārsta līmenis (Cuthbert \& Melamed, 1982; Klingberg et al., 1994; Milgrom et al., 1995; Raadal et al., 1995; Wogelius et al., 2003, Majstorovic \& Veerkamp, 2005). Tomēr bērnu vecuma un baiļu no zobārsta samazināšanās sakarība ne vienmēr bija lineāra (Milgrom et al., 1995; Raadal et al., 1995; Majstorovic \& Veerkamp, 2005; Akbay-Oba et al., 2009), saglabājoties atsevišķiem baiļu pieauguma ,pīķiem” vēlākos vecumos. Pētījumam līdzīgi rezultāti parādīti Majstorovičas un Verkampa pētījumā, kur 4-11 gadus veciem bērniem visaugstākais baiļu līmenis konstatêts četrgadīgajiem, turpmākā vecumā vidējā BTZ līkne gāja uz leju, bet 11 gadu vecumā atkal būtiski pieauga (Majstorovic \& Veerkamp, 2005). Baiļu no zobārsta samazināšanās, sākot no 4 gadu vecuma, varētu būt saistîta ar bērna vispārīgu attīstību un vārdu krājuma (pareizāk sakot, verbālās izpratnes) palielināšanos (Klingberg \& Broberg, 2009), kā arī ar psiholog̣isku un emocionālu nobriešanu (Lee et al., 2008). Savukārt, minētie „pīḳi”” šajā pētījumā var tikt skaidroti ar individuālajām atšķirībām, kā arī atrašanos krīzes vecumā un/vai individuālo pieredzi pie zobārsta.

\subsubsection{BTZ atšķirības starp dzimumiem}

Pētījumā netika konstatētas statistiski nozīmīgas bērnu BTZ atšķirības zēniem un meitenēm. Tas saskan ar rezultātiem vairākos līdzīgos pētījumos (Milsom et al., 2003; AkbayOba et al., 2009; Beena, 2013), bet atšķiras no lielākās daḷas pētījumu, kuros meitenēm ir augstāks baiļu no zobārsta līmenis nekā zēniem (Murray et al, 1989, Chellapah et al., 1990, Alvesalo et al., 1993, Raadal et al., 1995, Milgrom et al., 1995, Skaret et al., 1998; Versloot et al., 2004; Klingberg \& Broberg, 2007). 


\subsubsection{BTZ saistība ar bērna temperamenta iez̄̄mēm}

Bērnu bailēm no zobārsta bija statistiski nozīmīga korelācija ar bērna emocionalitāti. Tas nozīmē, jo izteiktākas bija bērnu bailes no zobārsta, jo spilgtākas ir bērna emociju ārējās izpausmes vecāku vērtējumā. Jo vieglāk bērns ir ierosināms uz jebkādu emociju izpausmi, jo lielāka ir iespēja, ka bērns spēcīgāk izpaudīs arī bailes no zobārsta. Negatīva emocionalitāte (jeb emocionalitāte, jeb neirotisms) bija saistīta ar bērnu uzvedības traucējumiem pie zobārsta visos gadījumos 8-12 gadu vecumā arī Arnrupas un līdzautoru 2007.gada publikācijā. Tomēr mūsu pētījumā bailēm no zobārsta nebija saistības ar bērna sabiedriskumu, aktivitātes līmeni, labilitāti vai kautrīgumu (atšksirībā no Gustafsones un līdzautoru 2007. gada pētîjuma) vecāku vērtējumā.

\subsubsection{BTZ saistība ar bērna vispārējo trauksmi}

Bērnu bailēm no zobārsta bija statistiski nozīmīga korelācija ar vispārējo trauksmi jeb satraucamību, spēju pašam nomierināties un pārdzīvojuma ilgumu. Tas nozīmē, jo bērns vairāk satraucas dažādās situācijās arī ārpus zobārsta un mazāk spēj pats nomierināties, un ilgāk pārdzīvo par nepatīkamo notikumu, jo izteiktākas bija bērnu bailes no zobārsta. Šie rezultāti saskan ar citiem pētījumiem, kuros konstatēts, ka bērniem ar vispārējo trauksmi, tai skaitā arī ikdienišķāas situācijās, biežāk atrod arī bailes no zobārsta (Chellappah et al., 1990; Klingberg et al., 1994; Klingberg et al., 1995; Folayan et al., 2004; Vogels et al., 2011; Stenebrand et al., 2013). Netika atrasti pētījumi par bērnu pārdzīvojuma ilguma un spējas pašam nomierināties saistību ar vidējo baiļu no zobārsta līmeni.

\subsubsection{BTZ saistība ar bērna citu baiḷu daudzumu}

Tāpat mūsu pētījumā tika konstatēta statistiski nozīmīga bērna baiḷu no zobārsta korelācija ar bērna bailēm no zirnekḷiem un kukaiṇiem. Bailes no zirnekḷiem ir vienas no izplatītākajām bailēm cilvēkiem (Kent \& Blinkhorn, 1991). US National Institute of Mental Health 2015. gada dati rāda, ka apmēram trešdaḷa (30,5\%) amerikāṇu cieš no bailēm no zirnekḷiem. Osterinka ar līdzautoriem norāda, ka no zirnekḷiem un zobu ārstēšanas baidās līdzīgs skaits cilvēku (attiecīgi, 23,3\% un 24,3\%) (Oosterink et al., 2009). Tomēr mūsu pētîjumā bailēm no zobārsta nebija saistības ne ar bailēm no palikšanas vienam vai no svešiem cilvēkiem, ne arī ar cita veida baiļu skaitu. Tas atšķiras no līdzīgiem pētījumiem, kuros teikts, ka respondentiem ar augstāku vidējo baiļu no zobārsta līmeni ir statistiski 
nozīmīgi lielāks cita veida baiḷu skaits (Berggren, 1992; Stenebrand et al., 2013). Iespējams, atšķirīgie rezultāti saistīti ar savādāku pētījuma dizainu un metodiku.

\subsubsection{BTZ saistība ar bērna uzvedību pie zobārsta}

Pētījumā tika konstatēta bērnu baiļu no zobārsta vidēji stipra, statistiski nozīmīga korelācija ar bērnu (negatīvu) uzvedību pie zobārsta, līdzīgi kā citās publikācijās (Suprabha et al., 2011; Klingberg et al., 1994). Tomēr Klingberga ar līdzautoriem atzīmē, ka negatīva uzvedība jeb uzvedības problēmas zobārsta kabinetā var arī nebūt saistīti ar bailēm no zobārsta, bet gan ar bērna temperamenta īpatnībām, piemēram, kautrīgumu (Klingberg \& Broberg, 2009) vai vispārējo trauksmi, depresiju vai raizēm (Gustafsson et al., 2010).

Savukārt Folajana un līdzautoru 2004. gada pētījumā nekonstatēja bērnu baiļu no zobārsta saistību ar viņu uzvedību zobārsta krēslā, tomēr pētījuma grupa bija nedaudz vecāka (8-13 gadi). Tāpat autori savas publikācijas diskusijā piel̦āva kultūras atšķirības, jo Nigērijā, kur veikts minētais pētījums, neesot pieņemts izrādīt tādas emocijas kā bailes publiski, īpaši vīriešiem.

\subsection{BTZ saistība ar ārējiem ğimenes faktoriem}

Šajā diskusijas daḷā tiks apspriestas bērnu bailes no zobārsta un to saistība ar ārējiem ǵimenes (vecāku/informācijas) faktoriem - vecāku baiļu un trauksmes līmeni zobārstniecībā, informāciju un bērna sagatavošanu zobārsta vizītei, kā arī vecāku sociālekonomiskajiem/ sociāldemogrāfiskajiem rādītājiem.

\subsubsection{Bērnu un vecāku BTZ savstarpējā saistība}

Bērnu un vecāku bailēm un trauksmei zobārstniecībā tika konstatēta vidēji stipra, statistiski nozīmīga savstarpējā korelācija, kas atbilst rezultātiem Temeslas-Huberas, kā arī Lahti un Luoto 2010. gada publicētajās metaanalīzēs, kā arī citos pētījumos (Milsom et al., 2003; Lee et al., 2008; Rantavuori et al., 2009; Jafardazeh et al., 2011; Ollak et al., 2013). Abās metaanalīzēs īpaši uzsvērts, ka vecāku un bērnu baiļu no zobārsta līmeṇu saistība ir ievērojama apmēram 80\% gadījumu (pētījumu), kad bērni ir jaunāki par 8 gadiem (ThemesslHuber et al., 2010, Lahti \& Luoto, 2010). Šādi rezultāti varētu būt saistīti gan ar vecāku trauksmes nodošanas mehānismiem bērniem (Fisak \& Grills-Taquechel, 2007), gan vecāku 
audzināšanas stilu ietekmi uz bērna uzvedību zobārsta kabinetā (Aminabadi et al., 2015), gan vecāku personīgās negatīvās zobārstniecības pieredzes atkārtošanu praksē ,uz bērniem” (Smith \& Freeman, 2010). Mātēm ar paaugstinātu trauksmi arī bērni ir ar augstāku trauksmes līmeni, un, iespējams, uztver zobārstniecības situāciju kā bīstamu (draudu un sodu) (Freeman, 2007), tāpēc baidās. Savukārt, Versloot ar līdzautoriem uzskatīja, ka bērna spēja tikt galā ar zobu ārstēšanu ir atkarīga ne tikai no bērna psiholoǵiskā un kognitīvā brieduma, bet arī no vecāku baiļu neesamības (angliski - absence) (Versloot et al., 2004). Protams, jo vecāki kḷūst bērni, jo kopā ar pieaugošu neatkarību lielāka kḷūst viṇu pašu, nevis vecāku pieredzes pie zobārsta loma (Kent \& Blinkhorn, 1991).

Rezultātu interpretācijā būtu jāņem vērā, ka anketas (CFSS-DS) par bērna bailēm no zobārsta aizpildīja vecāki, nevis paši bērni. Šāds lēmums, plānojot pētījumu tika pieņemts, lai varētu iegūt salīdzināmus mainīgo mērījumus visu vecumu bērniem, arī jaunākajiem $(4,5$ vai 6 gadus veciem), kas nevarētu paši izlasīt, noteikt un atzīmēt, cik lielā mērā viṇi baidās no smakšanas vai injekcijām. Tomēr paliek jautājums, vai un cik objektīvs ir vecāku novērtējums bērnu bailēm no zobārsta un vai to neietekmēja vecāku pašu bailes no zobārsta. Piemēram, Luoto ar līdzautoriem veica pētījumu, kurā 11-16 gadus veci bērni vērtēja savas un vecāku bailes no zobārsta, bet vecāki - savas un bērnu bailes no zobārsta. Autori nonāca pie secinājuma, ka bērni un vecāki nevar novērtēt viens otra bailes, jo gan bērnu BTZ pašvērtējuma un bērnu BTZ vecāku vērtējuma, gan vecāku BTZ pašvērtējuma un vecāku BTZ bērnu vērtējuma savstarpējā saistība nebija statistiski nozīmīgā līmenī (Luoto et al., 2010). Arī Patels un līdzautori 2015. gadā konstatēja, ka 7-16 gadus veciem bērniem bērnu BTZ pašvērtējuma un bērnu BTZ vecāku vērtējuma korelācija bija zema vai mērena $(0,17-0,34)$ (Patel et al., 2015). Savukārt Krikena ar līdzautoriem. konstatēja, ka vecāki, aizpildot anketas 7-11 gadus veco bērnu vārdā, viņu bailes novērtē nedaudz augstāk nekā paši bērni (Krikken et al., 2013), tomēr bērnu BTZ pašvērtējuma un bērnu BTZ vecāku vērtējuma korelācija bija mērena $(0,57)$. Vecāki ar augstāku trauksmes līmeni novērtēja savu bērnu bailes ievērojami augstāk nekā vecāki ar zemāku trauksmes līmeni (Krikken et al., 2013). Gustafsson et al. pētījumā 8-12 un 13-19 gadus vecu bērnu BTZ pašvērtējums un bērnu BTZ vecāku vērtējums korelēja mēreni „,normālu baiļu” grupā $(0,46)$, bet vājāk - ,izteiktu baiļu” grupā $(0,29)$ (Gustafsson et al., 2010). Līdzīgā pētîjumā Shindova et al. konstatēja, ka, lai gan vecāki novērtēja savu bērnu bailes augstāk nekā paši 6-12 gadus vecie bērni, atšksirības kopējā rezultātā nebija statistiski nozīmīgas (Shindova et al., 2014). Bērnu BTZ pašvērtējuma un bērnu BTZ vecāku vērtējuma savstarpējā korelācija bija 0,15 . Tomēr vecāku vērtējums par bērnu bailēm bija statistiski nozīmīgi paaugstināts trīs jautājumos - bailēm no „smakšanas”, „zobārstiem” un „kad zobārsts tīra tavus zobus” (Shindova et al., 2014). Tātad, pētījumi par 
to, cik lielā mērā bērnu BTZ vecāku vērtējumā ir objektīvs, ir pretrunīgi rezultāti dažādos pētījumos. Tomēr, neatkarīgi no izmantotās metodikas, pārsvarā visi konstatē, ka bērnu un vecāku bailēm no zobārsta ir savstarpēja saistība.

\subsubsection{BTZ saistība ar vecāku saṇemto un bērniem nodoto informāciju}

Pētījumā tika konstatēta bērnu baiļu no zobārsta statistiski nozīmīga korelācija ar vairākām bērna sagatavošanas metodēm, ko veic vecāki pirms zobārsta apmeklējuma, piemēram, ,apsola balvu par labu uzvedību pie zobārsta”, „mierina, ka neko nedarīs un nekas nesāpēs” un „stāsta par savu pieredzi pie zobārsta”. Tas nozīmēe, ka bērniem, kuriem ir bail no zobārsta, ir vecāki, kuri baidās no zobārsta, kuri nevis paskaidro, kas tiks darīts vizịtes laikā, bet saka, ka pie zobārsta neko nedarīs un nekas nesāpēs, saka, lai bērns neuztraucas, vai vienkārši apsola balvu par labu uzvedību. Trauksme neziņas dēl par gaidāmo (angliski anticipatory anxiety) būtiski ietekmē bērna uzvedību, jo sašaurina pacienta kognitīvos procesus, kā uzmanību, atminu un domāšanu (Jaakkola et al., 2014). Arī vecāki, kas „stāsta par savu pieredzi pie zobārsta” izdara bērniem ,lāča pakalpojumu” un neapzināti sabiedē, ja šī pieredze ir negatīva. Neitrāla stimula gadījumā īpaša loma trauksmes nodošanā ir vecāku teiktajam un tai emocionālajai attieksmei, ko nodod attiecībā uz šo stimulu vecāki kā bērnam svarīgas personas (Field \& Lawson, 2003). Bērna bailes un trauksmi pastiprina nevis tikai informācijas pārneses veids, bet gan informācija kombinācijā ar vecāku trauksmainu uzvedību, kā arī vecums, kurā negatīvā informācija tika prezentēta (Fisak \& Grills-Taquechel, 2007).

Mūsu pētījums parādīja, ka bērniem, kurus vecāki nekā īpaši nesagatavoja pirms zobārsta vizītes, kā arī pārrunāja bērna mutes kopšanas paradumus ar zobārstniecības speciālistiem, bija zemāks baiḷu no zobārsta līmenis. Iespējams, šādi rezultāti norāda uz vecāku zemāku BTZ līmeni, uzticēšanos un paļaušanos uz zobārstiem un zobu higiēnistiem. Savukārt, to vecāku bērniem, kas informāciju par mutes dobuma kopšanu vai bērna sagatavošanu vecāki smēlās plašsaziņas līdzekḷos un pie draugiem un paziņām, nevis pie zobārstiem vai zobu higiēnistiem, bija augstāks BTZ līmenis. To apstiprina Jepa un Slaksmitas atsauces, ka vairāk nekā puse pieaugušo amerikāņu ir izmantojuši internetu, lai atrastu informāciju par veselības jautājumiem (Fox, 2011; Yeap \& Slack-Smith, 2013). Informācija par bērna (pirmo) vizīti pie zobārsta bija viegli atrodama internetā, tomēr ne visos gadījumos precīza, īpaši speciālistu (zobārstu) un vēl jo vairāk neprofesionāļu (vecāku) savstarpējā atbalsta forumos (Yeap \& Slack-Smith, 2013). Pētījuma rezultāti saskan ar Šina un līdzautoru pētījumu, ka vecākiem ar lielākām bailēm no zobārsta ir raksturīgas vājākas 
zināšanas par mutes veselību, kā arī sliktāka bērnu mutes veselība, jo, iespējams, vecāki nesaprot informāciju par bērna diagnozi un ārstēšanas plānu (Shin et al., 2014). Tātad, ne vienmēr informācijai, kas publicēta medijos vai internetā, var uzticēties, tāpēc ir svarīgi, informāciju par mutes veselību un arī BTZ profilaksi padarīt publiski pieejamāku un vizuāli atraktīvāku, lai tai varētu viegli piekḷūt un apgūt.

Atšksirībā no literatūras apskatā minētiem pētījumiem, netika konstatēta bērnu baiļu no zobārsta statistiski nozīmīgas korelācija ar bērna biedēšanu ar zobārstu kā soda metodi, zobārsta vizịtes atlikšanu bez īpaša iemesla un vecāku negatīvās pieredzes pārrunāšanu bērna klātbūtnē. Iespējams, tas saistīts ar anketas subjektivitāti, respektīvi, vecāki neapzinās, ka viņi biedē ar zobārstu kā soda metodi vai pārrunā savu pieredzi bērna klātbūtnē (ja būtu iespējams šos teicienus konkretizēt vai piefiksēt ar novērošanas palīdzību, rezultāti varētu atšķirties).

\subsubsection{BTZ saistība ar vecāku sociālekonomiskajiem rādītājiem}

Pētījumā tika konstatēta bērnu baiļu no zobārsta negatīva, statistiski nozīmīga korelācija ar tādiem sociālekonomiskajiem rādītājiem kā ǵimenes locekḷu skaits, mājsaimniecības locekḷu skaits, bērnu skaits ğimenē, kā arī tēva izglītība, bet netika konstatēta korelācija ne ar ienākumu līmeni, ne vecāku vecumu, ne nodarbinātību, ne laulības statusu. Bērnu baiḷu līmenis samazinājās, pieaugot ğimenes lielumam. Iespējams, lielākās gímenēs ir pierasts vairāk rūpēties vienam par otru, gūstot lielāku pieredzi no brāḷiem un māsām. Citā publikācijā to saista ar iemācītu lielāku pacietību, toleranci un sadarbošanos (Pai et al., 2015). Mūsu pētījumā netika jautāts, vai bērni ir vecākie vai vienīgie bērni gímenē, līdz ar to nav iespējams salīdzināt ar līdzīgiem rezultātiem citos pētījumos.

Pētījums parādīja, ka, jo labāka bija tēva izglītība, jo mazākas bija bērnu bailes no zobārsta. Viens no potenciālajiem izskaidrojumiem atrodams Laras un līdzautoru publikācijā, kurā minēts, ka bērni uztver tēvus kā pamatinformācijas avotus, pēc kuru teiktā izdara secinājumus, vai zobārstniecība ir bīstama vai nav (Lara et al., 2012). Tomēr kopumā tēva izglītības saistību ar bērnu BTZ ir samērā grūti izskaidrot, vēl jo vairāk tāpēc, ka rezultāts tikai gandrīz sasniedz statistiskās nozīmības robežu $(\mathrm{p}=0,044)$. Pereca un līdzautoru pētījumā, kurā bērni un vecāki bija līdzīgā vecuma amplitūdā (bērni 6-14 gadi, vecāku vecums 30-52 gadi), vecāku izglītība nekorelēja ar bērnu bailēm no zobārsta un vecāku vecumu (Peretz et al., 2004). Tomēr minētajā pētījumā bērnu bailes no zobārsta nekorelēja arī ar bērnu skaitu, atšķirīibā no Latvijas pētījuma. Bailes nekorelēja arī ar zemu sociālekonomisko stāvokli jeb ienākumu līmeni, atšķirībā no vairākiem citiem pētījumiem (Klingberg et al., 1994; Arnrup et al., 2002, Gustafsson et al., 2007; Armfield et al., 2007; 
Rantavuori et al., 2009; Shin et al., 2014). Kopumā var teikt, ka bērnu baiļu no zobārsta korelācijai ar sociālekonomiskajiem vai sociāldemogrāfiskajiem faktoriem pētījumos ir pretrunīgi rezultāti (atšķirībā no diezgan viendabīgiem rezultātiem saistībā ar bērna vecumu, dzimumu vai vecāku bailēm). Vairākos pētījumos nav atrasta nekāda saistība ar sociālekonomiskajiem faktoriem (Milsom et al., 2003; Mehrstedt et al., 2004), vai tie variē dažādos pētījumos atkarībā no pētījuma izlases. Atsevišķi autori apgalvo, ka 15 gadus vecu pusaudžu vispārējām bailēm un/vai trauksmei, un attieksmei pret zobārstniecības personālu vispār ir lielāka nozīme nekā tādiem sociāldemogrāfiskajiem faktoriem kā vecums un mātes vecāku izglītība (Stenebrand et al., 2013).

\subsection{BTZ saistība ar ārējiem zobārstniecības faktoriem}

Šajā diskusijas daļā tiks apspriestas bērnu bailes no zobārsta un to saistība ar ārējiem zobārstniecības faktoriem - bērna vecumu pirmās zobu apskates un pirmās zobu ārstēšanas laikā, iepriekšēju negatīvu pieredzi zobārstniecības situācijās, bērna traumatisku medicīnisku pieredzi (bērna ārstēšanos slimnīcā un/vai hroniskas saslimšanas).

\subsubsection{BTZ saistība ar bērna pirmo vizīti pie zobārsta (iemeslu un bērna vecumu)}

Bērnu bailēm no zobārsta tika konstatēta statistiski nozīmīga negatīva korelācija ar vecāku nosaukto bērna vecumu (mēnešos) pirmā zobārsta apmeklējuma laikā. Tas nozīmē, ka teorētiski bērniem, kuri ir (pēc vecāku norādītās informācijas) agrākā vecumā apmeklējuši zobārstu, tiešām ir mazākas bailes no zobārsta. Tas saskan ar teorētiskajā daḷā minētiem rezultātiem (Welly et al., 2011). Tomēr šì baiļu no zobārsta negatīvā korelācija ar vecāku nosaukto bērna vecumu pirmās vizịtes laikā jāvērtē kritiski, jo, BTZ salīdzinot tikai ar dokumentāli pierādāmo bērna vecumu pirmās vizītes laikā, korelācija netika konstatēta (bērnu bailēm no zobārsta nebija statistiski nozīmīgas korelācijas ar bērnam veiktu zobu apskati). Tāpat bērniem vienādā vecumā emocionālais un kognitīvais briedums var būt ļoti atšķirīgs.

Vairāk nekā puse respondentu atzīmēja, ka devušies ar bērnu pirmajā vizītē pie zobārsta profilaktisku iemeslu dēḷ. Šie rezultāti atpaliek no situācijas Skandināvijā, kur visi bērni tiek uzaicināti uz profilaktiskajām pārbaudēm 1 gada vecumā mātes un bērna veselības centros (Poulsen, 2003). No otras puses, mūsu pētījuma rezultāti atšksiras no Taivānā, Bulgārijā un Indijā veiktajiem pētījumiem, kur apmēram pusei no bērniem pirmās vizītes pie zobārsta iemesli bija saistīti ar kariesu vai sāpēm (Lee et al., 2008; Mileva \& Kondeva, 2010; Meera et al., 2008). Protams, viens no iemesliem varētu būt atmiņas kḷūdas, īpaši attiecībā uz 
vecāko bērnu grupu. Ja attiecībā uz pirmo bērnam veikto plombēšanu un ekstrakciju ir viegli iegūt rezultātus no ambulatorās kartes, tad pirmo apmeklējumu un tā iemeslu noteikt pēc ieraksta kartin̄ā nereti ir daudz grūtāk. Bērnu bailēm no zobārsta nebija statistiski nozīmīgas korelācijas arī ar bērna vešanu pie zobārsta, kad zobi nedaudz sāp vai traucē un pirmo zobārsta vizīti sakarā ar pamanītām izmaiṇām zobos.

\subsubsection{BTZ saistība ar iepriekšējo pieredzi pie zobārsta}

Bērnu bailēm no zobārsta nebija statistiski nozīmīgas korelācijas ar bērnam veiktu zobu apskati, zobu plombēšanu bez anestēzijas un zoba ekstrakciju vietējā anestēzijā. Tātad, teorētiskajā daļā minētā bērnu baiļu no zobārsta saistība ar ekstrakcijām (Milsom et al., 2003) vai zobu ārstēšanu bez anestēzijas (Klingberg et al., 1994) šajā pētījumā netika apstiprināta. Tas varētu būt saistîts, piemēram, ar mazo respondentu skaitu, kam bija iespējams pēc ambulatorās kartiņas precīzi noteikt, vai tiek plombēts un ekstrahēts pirmo reizi.

Pārbaudot saistību starp bērnu bailēm no zobārsta, bērnu zobārstniecības pieredzi un attieksmi pret zobārstiem, mūsu pētījumā tika konstatēta cieša statistiski nozīmīga pozitīva korelācija ar grūtībām iepriekšējās zobu ārstēšanas laikā, bērna bailēm un raudāšanu pie zobārsta, bērna paniku un histēriju pie zobārsta, kā arī bērna aktīvu protestu un pretestību, ejot pie zobārsta. Tāpat bērna bailēm no zobārsta bija statistiski nozīmīga korelācija ar bērna negatīvu pieredzi pie zobārsta un negatīvas pieredzes pārvarēšanu, ārstējot zobus vispārējā anestēzijā, bērnam veiktu zobu ārstēšanu vispārējā anestēzijā, bērna nevešanu pie zobārsta vispār un bērna vešanu pie zobārsta dienas pirmajā pusē. Tas nozīmē, ka bērni ar lielākām bailēm no zobārsta biežāk izrāda bailes un raud vai aktīvi protestē, vai krīt panikā vai histērijā, ejot pie zobārsta, viņiem ir bijusi negatīva pieredze pie zobārsta, zobu ārstēšana vienmēr vai gandrīz vienmēr noritējusi ar lielām grūtībām, un zobi ir ārstēti vispārējā narkozē. Tas precīzi saskan ar citu pētījumu, kurā konstatēts, ka bērniem, kuru vecāki atzīmēja iepriekšējo pieredzi pie zobārsta kā negatīvu, tika biežāk novērota nekooperatīva uzvedība turpmākajos apmeklējumos (Pai et al., 2015). Lai gan mūsu pētījuma anketā netika škirots, ar ko tieši saistīta bērna iepriekšèjā negatīvā pieredze (sāpēm vai nepatīkamu attieksmi), pētījumi rāda, ka sāpes ir viens no svarīgiem baiļu no zobārsta iemesliem (Versloot et al., 2004). Ja bērns vienreiz ir izjutis sāpes, tas veicina paliekošu baiḷu no zobārstniecības izveidošanos (Harman et al., 2005; Freeman, 2007). Cits pētījums arī parāda, ka ne tikai sāpes ietekmē bailes no zobārsta, bet arī notiek atgriezenisks process - bailes no zobārsta ietekmē bērna sāpju līmeni (Lee et al., 2008). 
Savukārt mūsu pētījumā statistiski nozīmīga negatīva korelācija bailēm no zobārsta tika konstatēta ar bērna neitrālu attieksmi vai prieku un interesi, ejot pie zobārsta, bērnam iepriekš veiktu zobu higiēnu, iepriekš veiktu plombēšanu vietējā anestēzijā un vecāku nosaukto bērna vecumu (mēnešos) pirmā zobārsta apmeklējuma laikā. Tas nozīmē, bērniem, kuriem ir veikta zobu higiēna un ārstēšana ar atsāpināšanu, un ir pozitīva vai neitrāla attieksme pret zobārstu, ir mazākas bailes no zobārsta. Šie rezultāti saskan ar citiem pētījumiem, ka, jo vairāk pārbaudes vizīšu bērniem ir bijis, pirms viņi pieredzējuši zobu ārstēšanu, jo mazākas ir bailes no zobārsta (Davey, 1989; Rantavuori et al., 2009), ka bērniem, kuriem ārstēšana veikta vietējā anestēzijā, ir mazākas bailes no zobārsta (Klingberg et al., 1994), un ka bērniem, kas sāpes pie zobārsta izjuta dažreiz vai nekad, bija zemāks vidējais baiḷu no zobārsta līmenis (Versloot et al., 2004). Tāpat jāņem vērā, ka zobārstniecības personāla izteikta pacienta kritizēšana, piespiešana, pazemošana un turēšana palielināja jaunās paaudzes bailes no zobārsta (Zhou et al., 2012), un ka bērni un pusaudži ar BTZ ir jūtīgāki pret zobārstniecības personāla uzvedību un attieksmi un biežāk uztver to kā rupju vai neuzmanīgu (Jaakkola et al., 2014).

\subsubsection{BTZ saistība ar bērnu traumatisku medicīnisko pieredzi}

Pārbaudot saistību starp bērnu bailēm no zobārsta, bērnu medicīnisko pieredzi un attieksmi pret ārstiem (izņemot zobārstus), tika konstatēta bērnu BTZ statistiski nozīmīga pozitīva korelācija ar bērnu slimošanas biežumu, ārsta apmeklējumu vairāk nekā 4 reizes gadā, piesardzīgu un bailīgu attieksmi pret ārstiem, kā arī traumatisku pieredzi pie ārstiem, izņemot zobārstus. Bērnu bailes no zobārsta statistiski nozīmīgi negatīvi korelēja arī ar draudzīgu un neitrālu attieksmi pret ārstiem, kā arī bērna vecumu, ciešot pirmo fizisko traumu, kuras dēl bija nepieciešama neatliekamā palīdzība. Tas nozīmē, jo agrākā vecumā bērni cietuši no kādas smagas fiziskas traumas, jo biežāk šie bērni ir slimojuši un apmeklējuši ārstu, un jo piesardzīgāka un bailīgāka bija viņu attieksme pret ārstiem vispār, jo, iespējams, lielākas ir arī viṇu bailes no zobārsta. Netika konstatēta bērnu baiḷu no zobārsta statistiski nozīmīga korelācija ar hroniskām saslimšanām.

Šie rezultāti daḷēji saskan ar rezultātiem citos pētījumos, ka bailes no zobārsta var būt saistītas ar medicīniskām bailēm, ja bērniem ir vai ir bijušas hroniskas, biežas vai smagas saslimšanas (Karjalainen et al., 2003; Wogelius et al., 2003), vai bieži jāapmeklē ārsti vai jāpaliek slimnīcā (Davey, 1989; Hollis et al., 2015), kā arī tad, ja ir bijusi kāda traumatiska medicīniska pieredze, piemēram, invazìva ārstēšana vai medicīniska manipulācija, kas veikta piespiežot ar spēku (Mayou \& Smith, 1997; Karjalainen et al., 2003; de Jongh et al., 2006). 
Tāpat bailes no zobārsta var parādīties saistībā ar sadzīvisku fizisku vai psiholoǵisku traumu (de Jongh et al., 2006). BTZ negatīvi korelēja arī ar bērna vecumu pirmās fiziskās traumas gadījumā, bet nevis ar vecumu pirmās traumatiskas pieredzes pie ārstiem, tad varētu piel̦aut, ka, jo mazāks ir bērns, jo samazinās iespēja, ka viņš spēs apstrādāt šīs traumas sekas (izbīli, sāpes, sekojošu neatliekamo medicīnisko palīdzību un ārstēšanu) kognitīvi, ar prātu. Šajā gadījumā bailes no zobārsta varētu būt kā daḷa no posttraumatiskā stresa sindroma.

No vienas puses, netika atrasta BTZ korelācija ar bērnu hroniskām saslimšanām. No otras puses, parādījās saistība ar slimošanas biežumu un ārstu biežu apmeklējumu, kā arī traumatisku pieredzi ar ārstiem. To varētu izskaidrot, ka ne visu hronisko saslimšanu ārstēšana ir traumatiska (piemēram, bronhiālās astmas gadījumā), atšksirībā no onkologiiskajām vai kaulu deformācijas slimībām. Tādējādi pozitīva BTZ korelācija ar piesardzīgu un bailīgu attieksmi, un negatīva korelācija ar draudzīgu un neitrālu attieksmi pret ārstiem netieši apstiprina Armfîlda kognitīvās ievainojamības teoriju, ka attieksmei pret ārstiem ir lielāka noz̄̄me nekā tiešai negatīvai pieredzei (Armfield, 2006). Apstiprinās arī citā pētījumā izteiktā hipotēze, ka iepriekšējo viz̄̌šu emocionālā kvalitāte ir nozīmīgāka nekā vižšsu skaits (Suprabha et al., 2011) un bērni, kas savu iepriekšējo medicīnisko pieredzi uztver kā pozitīvu, sadarbosies arī zobārstniecības klīnikā (Wright, 2000; Suprabha et al., 2011). Šādi, iespējams, var izskaidrot to, ka vairākos pētījumos netika atrasta saistība starp bērna bailēm no zobārsta un biežām vai hroniskām saslimšanām (Wogelius et al., 2009; Suprabha et al., 2011; Paryab \& Hosseinbor, 2013; Dogan et al., 2013).

\subsection{BTZ saistība ar mutes veselību}

Pētījumā tika konstatēta bērnu BTZ statistiski nozīmīga pozitīva saistība gan ar kariozo zobu skaitu (piena un pastāvīgajiem zobiem), gan ar kopējo KPE (KPE + kp) un kp. Pētījumā iegūtie rezultāti saskan ar Igaunijā veikta pētījuma rezultātiem, kurā 8 līdz 11 gadus vecu bērnu kpez/KPEz un kariozo zobu skaits bija statistiski nozīmīgi saistīts ar bērnu (kopējām) bailēm no zobārsta (Saag \& Olak, 2014). Vairākos pētījumos minēts, ka pacientiem ar augstāku baiļu no zobārsta līmeni ir augstāki kp, kpe, kp/KPE un/vai KPE rādītāji gan bērnu (Milsom et al., 2003; Akbay-Oba et al., 2009; Beena, 2013), gan pusaudžu (Bedi et al., 1992; Kruger et al., 1998), gan pieaugušo izlasēs (Cohen, 1985; Armfield et al., 2009). Mūsu pētījuma rezultāti saskan ar rezultātiem citās publikācijās, ka grupām ar augstāku vidējo baiḷu no zobārsta līmeni ir vairāk kariozu zobu gan pētījumos ar bērniem (Klingberg et al., 1995), gan pieaugušajiem (Cohen, 1985; Eitner et al., 2006). Tomēr citos pētījumos atrasti pretrunīgi rezultāti par BTZ saistîbu ar plombētiem zobiem. Ir pētījumi, 
kuros BTZ negatīvi korelē ar bailēm no zobārsta (tas ir, jo augstāks BTZ līmenis, jo mazāk plombētu zobu) (Klingberg et al., 1995; Cohen, 1985). Vienlaicīgi ir pētījumi, kuros plombēto zobu skaits neatšksiras grupās ar augstiem un zemiem BTZ rādītājiem (Eitner et al., 2006) vai pat bija vairāk plombētu zobu (Bedi et al., 1992). Iespējams, svārstīgos rezultātus ietekmē cits fenomens, proti, baiļu no zobārsta saistība ar plombētiem zobiem ir apgriezta U-veida, t.i., ja respondentiem ir nedaudz bail, tad plombēto zobu skaits pieaug, savukārt tālāk pieaugot baiļu pakāpei, plombēto zobu skaits ievērojami samazinās (Armfield et al., 2009).

Citi pētījumi rāda, ka ekstrakcijas ir nozīmīgs faktors baiḷu no zobārsta etioloǵijā (Bedi et al., 1992; Thomson et al., 2000; Milsom et al., 2003). Mūsu pētījumā netika konstatēta baiḷu no zobārsta statistiski nozīmīga korelācija ar plombēto zobu skaitu (piena un pastāvīgajiem zobiem), ne arī ar ekstrahēto zobu skaitu. Iespējams, rezultāti būtu savādāki, ja tiktu ņemti vērā arī priekšlaicīgas piena zobu ekstrakcijas. Tomēr, saskaņā ar pētījuma laikā pieņemto metodiku, piena zobu ekstrakcijas netika reǵistrētas, savukārt ekstrahētu pastāvīgo zobu bija pārāk maz $(\mathrm{n}=10)$, lai izdarītu secinājumus par savstarpēju sakarību.

Atsevišksos pētījumos netika konstatēta BTZ korelācija ne ar KPE (Taani et al., 2005; Samorodnitzky \& Levin, 2005; Yuzugullu et al., 2014) ne kariozo zobu skaitu (Vignehsa et al., 1990).

\subsection{BTZ izskaidrojošo faktoru regresijas analīze.}

Pētījums parādīja, ka vislabāk bērnu bailes no zobārsta izskaidro ar zobārstniecības pieredzi saistītie faktori un bērna personības faktori. Nedaudz mazāk bērnu BTZ izskaidroja vecāku/informācijas un bērna medicīniskās pieredzes faktori. Savukārt sociālekonomiskie faktori un zobu kopšanas paradumi bailes no zobārsta izskaidroja pavisam nelielā mērā. Kopumā netika atrastas publikācijas, kurās būtu pārbaudīts visu iepriekšminēto faktoru ieguldījums bērna baiḷu no zobārsta etiolog̣ijā. Majstorovičas un līdzautoru pētījumā veiktajā regresijas analīzē iepriekšējā traumatiskā medicīniskā pieredze izskaidroja aptuveni 33-43\% no baiḷu no zobārsta variācijas (Majstorovic et al., 2001), kas labi saskan ar mūsu pētījuma rezultātiem. Lī un līdzautoru pētîjumā mātes bailes no zobārsta, nesadarbošanās pirmās vizītes laikā, vecums līdz 4 gadiem, spēcīgas sāpes pirmās vizītes laikā un dažādu zobārstniecības klīniku apmeklējums bija faktori, kas izskaidroja 36,2\% no baiļu no zobārsta variācijas (Lee et al., 2008). 


\subsection{Pētījuma ierobežojumi}

Pētījumam kopumā bija augsta ticamība un validitāte. Mērījumi tika veikti ar ticamiem instrumentiem - CFSS-DS aptaujas Kronbaha alfa jeb ticamība bija 0,91, savukārt MDAS šis rādītājs bija 0,85. Frankla skalai, kurā tika veikts bērna uzvedības novērtējums, ticamība bija limitēta (jo novērtējums tikai 1 skalā), tomēr tā ir tikusi izmantota daudzos līdzīgos pētījumos.

CFSS-DS ir ļoti bieži izmantota aptauja baiļu no zobārsta novērtēšanai pirmsskolas un jaunākā skolas vecuma bērniem (Alvesalo et al., 1993; Milgrom et al.,1994; ten Berge et al., 1998; ten Berge et al., 2002; Majstorovič et al., 2003, Arapostathis et al., 2008). Tomēr nav iespējams kvalitatīvi salīdzināt Latvijas bērnu datus ar citu pētījumu rezultātiem, jo atšksiras pētījuma vecuma grupas un vides. Oriǵinālajā pētījumā aptaujāti bērni no 5 līdz 13 gadu vecumam (Cuthbert \& Melamed, 1982), bet vēlākos pētījumos, kuros parādās parādās visdažādākās vecuma grupas, piemēram, 4-14 gadus (Klingberg, 1994), 5-15 gadus (Majstorovič et al., 2003), 4-12 gadus (ten Berge et al., 1998; Arapostathis et al., 2008) un 5-8 gadus veci bērni (Chellappah et al., 1990), bet Alvesalo ar līdzautoriem vispār nenorādīja pētījuma grupas vecumu, tikai atzīmēja, ka vidējais bērnu vecums bija 13 gadi (Alvesalo et al., 1993). Š̀̃ aptauja ir piemērota gan bērnu, gan vecāku variantā, un ir tikusi izmantota pētījumiem gan klīniskajā vidē (Arapostathis et al., 2008), gan ārpus tās (skolās) (Chellappah et al., 1990), gan frontāli (Alvesalo et al., 1993), gan neklātienē (vēstulēs) (Cuthbert \& Melamed, 1982; Klingberg, 1994). Diemžēl nevienu no publicētajiem pētījumiem nevarēja izmantot, lai salīdzinātu rezultātus ar mūsu pētījumā iegūtajiem - vai nu atšksīīās pētījumā apskatītās vecuma grupas, vai nebija norādītas bērnu BTZ atšķirības dažādos vecumos, vai arī atšķ̧īrās datu iegūšanas vide un respondenta tips. Tāpēc mūsu pētījumā iegūtos rezultātus par bērnu bailēm un trauksmi zobārstniecībā Latvijā nebija iespējams ticami salīdzināt ar citās valstīs iegūtajiem rezultātiem. CFSS-DS aptauja satur 15 dažādus jautājumos. Šì pētījuma ietvaros publicētajā rakstā redzams, ka ne visi jautājumi ir ar augstu ticamību, piemēram, jautājums „cik lielā mērā Jūsu bērns baidās, kad kāds pētoši skatās uz viņu” ne īpaši labi raksturoja bērna bailes no zobārsta. Piemēram, citas aptaujas, kā Kleinknehta zobārstniecības baiļu aptauja (angliski - Dental Fear Survey jeb DFS) precīzāk raksturo bailes un trauksmi zobārstniecībā, jo tur pievienoti arī jautājumi par ekstrakcijām un izvairǐšanos no zobārsta apmeklējumiem (Kleinknecht \& Bernstein, 1978). Tomēr šo anketu izmanto tikai, sākot no pusaudžu vecuma, līdz ar to mūsu pētījumam tā nebija piemērota. Savukārt MDAS, kas tika izmantota, lai noteiktu vecāku bailes no zobārsta, nepietiekami niansēti raksturoja tieši bērnu bailes un trauksmi zobārstniecībā, jo neaptver jautājumus par slimnīcu vai satikšanos ar 
svešiem cilvēkiem, u.tml. Tāpēc mūsu pētījumā BTZ noteikšanai tika izvēlēta CFSS-DS aptauja.

MDAS ir aptauja, kas pārsvarā tiek izmantota, aptaujājot pieaugušos par bailēm un trauksmi zobārstniecībā. Š̀̄ aptauja balstās uz 1969. gadā publicētu Koras zobārstniecības baiļu skalu (angliski - Corah Dental Anxiety Scale), kas sastāvēja no 4 jautājumiem par vizīti pie zobārsta nākošajā dienā, izjūtām pirms ieiešanas zobārsta kabinetā, pirms zobārsts sāk urbt (Corah, 1969). Modificētajā zobārstniecības baiḷu skalā jeb MDAS pievienots jautājums par pacienta izjūtām tieši pirms anestēzijas injicēšanas, jo pētījumos tika pierādīts, ka bailes no injekcijām ir nozīmīga baiḷu no zobārsta sastāvdaļa (Humphris et al., 1995). MDAS arī atbilžu varianti tika pārveidoti uz Likerta skalu no 1 („nemaz nebaidos”) līdz 5 („,̧oti stipri baidos”). Tomēr mūsu pētījumā tika atstāti oriǵinālie (Corah Dental Anxiety Scale) atbilžu varianti no 1 (,justos brīvi”) līdz 5 (nosvīstu vai justu fizisku nelabumu”), jo šie formulējumi l̦āva respondentiem labāk saprast un novērtēt savas izjūtas saistībā ar zobārsta apmeklējumu.

Aptauja par bērna attieksmi pret zobārstu tika konstruēta no jauna. Autore izstrādāja jautājumus, balstoties uz literatūru, kā arī uz savu pieredzi un novērojumiem, strādājot bērnu zobārstniecībā. Kopumā jautājumi par psihosociālajiem faktoriem 7 blokos un piedāvātie atbilžu varianti bija pietiekoši plaši. Tomēr netika fiksēts apmeklējumu skaits pie zobārsta, atbildējušo vecāku dzimums un dzīvesvieta (Rīga, mazāka pilsēta vai lauki). Jautājums par bērna negatīvo pieredzi pie zobārsta un izvairīšanās pieredzi no zobārsta varēja tikt noskaidrots precīzāk, savukārt jautājumi par mammas reakciju uz bērna stresu - mazāk niansēti. Aptaujā netika jautāts, vai pirmsskolas vecuma bērns apmeklē pirmsskolas izglītības iestādi, jo aptaujāti tika 4 līdz 12 gadu vecu bērnu vecāki, un tādējādi lielākajai daļai respondentu šis jautājums varētu būt neatbilstošs.

PVO anketa tiek plaši izmantota pētījumos par mutes (zobu) stāvokḷa noteikšanu. Kopumā šì metode l̦āva viegli atšksirt piena zobu statusu no pastāvīgo zobu statusa, kā arī reg̣istrēt gan kariozos, gan plombētos zobus. Tomēr šai metodei bija arī vairāki trūkumi. Viens no trūkumiem bija tāds, ka nebija iespējams atzīmēt, kad zobi bija ar defektu vai plombēti traumas, bet kad - kariesa dēḷ. Tāpat nebija iespējams atzīmēt, kurā gadījumā piena zobs bija ekstrahēts, bet kurā - izkritis dabiski (un vēl nebija šķīlies pastāvīgais zobs). Tāpat grūtības radīja situācija, kad mutē persistēja piena zoba sakne un vienlaikus jau bija izšķ̄ilies pastāvīgais zobs.

Frankla skala ir viena no divām visbiežāk pielietotajām metodēm, lai novērtētu bērna uzvedību zobārsta kabinetā. Frankla skalā bērna uzvedībai ir 4 vērtējumi: divi - pozitīvi, bet divi - negatīvi, un tā joprojām tiek izmantota zinātniskajos pētījumos, kaut arī izgudrota pirms vairāk nekā 50 gadiem (Frankl et al., 1962). Lai gan Venhema skalā ir 6 vērtējumi 
(Venham et al., 1980) un tā, iespējams, niansētāk raksturo bērna uzvedību zobārstniecības kabinetā, pēc autores domām, tā vairāk piemērota klīniskās situācijas un iespējamās terapijas metodes novērtēšanai nekā pētniecībai.

Aptaujas ir ļoti plaši izmantota metode, ja informācija nepieciešama par dažādiem respondentu paradumiem. Lai iegūtu salīdzināmus rezultātus par dažāda vecuma bērniem, visas anketas šajā pētījumā aizpildīja vecāki. Lai gan lielākie bērni, piemēram, 10, 11 vai 12 gadus vecie bērni noteikti spētu uz lielāko daļu jautājumu par izjūtām zobārstniecības kabinetā atbildēt paši, mazākajiem bērniem (4, 5 vai 6 gadus veciem) uz šiem jautājumiem atbildēt nebūtu pa spēkam. Vienlaikus, šis aspekts veido būtisku pētījuma ierobežojumu, jo arī par bērna izjūtām aptaujas aizpildīja vecāki. Neskatoties uz to, ka aptaujā tika dots norādījums šaubu gadījumā konsultēties ar bērnu, autori nevar izvērtēt, cik lielā mērā bērna viedoklis tika ņemts vērā katrā individuālajā gadījumā, bet cik - tika atstāts vecāku subjektīvajai interpretācijai. Šis ierobežojums varēja iespaidot rezultātus attiecībā uz bērna subjektīvo vērtējumu, piemēram, bērna baiļu no zobārsta novērtējumu, bērna negatīvo pieredzi pie ārstiem vai zobārstiem, bērna attieksmi pret kādu procedūru. Tomēr vecāku iesaistīšana nevarēja ietekmēt rezultātus objektīvām parādībām, piemēram, cik bieži bērns dodas pie ārsta vai slimo, cik regulāri tīra zobus, kurš visbiežāk ved bērnu pie zobārsta, un tamlīdzīgi.

Otrais ierobežojums attiecas uz parādībām, kas tika aizpildītas pēc atminas. Ja attiecībā uz zobu stāvokli, piemēram, tika izmantoti tikai tie dati, kurus varēja apstiprināt ar ierakstu zobārstniecības ambulatorajā kartiņā, tad attiecībā uz medicīnisko procedūru, hospitalizāciju skaitu un bērna vecumu, var viegli tikt izdarītas kḷūdas (līdzīgi, kā vecāki nereti kḷūdījās, mēǵinot atcerēties bērna vecumu pirmās ārstēšanas laikā).

Nākošais ierobežojums saistîts ar izmantotajām anketām. Iespējams, pētījumā būtu precīzāki rezultāti attiecībā uz personības iezīmēm, ja tiktu izmantotas standartizētas anketas. No otras puses, anketai jau pētījuma brīdī bija 10 lapas, un aizpildīšana aizṇēma 20-30 minūtes. Pagarinot pētījumu līdz 13-15 lapām, arī pētījuma anketas aizpildīšanas laiks pagarinātos par apmēram vienu trešdaļu, un ievērojami tiktu apgrūtināta respondentu piesaiste. Jāatzīst, ka vecāki pie zobārsta nelabprāt atbildēja uz jautājumiem, kas attiecas uz bērna psiholoǵisko attīstību un personību.

Runājot par iegūtajiem rezultātiem, var diskutēt, cik tie ir objektīvi, jo rezultātos lielāka saistība ir bērna reakcijai (bailēm un raudāšanai) nekā objektīvai traumai (negatīvai pieredzei). Tomēr rezultāti saskan ar Armfîlda teoriju par kognitīvo ievainojamību - nozīme ir nevis pašam notikumam, bet cilvēka attieksmei pret to, t. i., ko viņš domā par šo notikumu. 
Pētījuma izlase kopumā bija pietiekami plaša $(n=240)$, tika kontrolēts arī dalībnieku vecuma un dzimuma sadalījums. Šāda izlase l̦āva iegūt validus datus un priekšstatu par visdažādākajiem psihosociālajiem faktoriem, kas varētu būt saistīti ar bērna bailēm no zobārsta, tai skaitā par bērna līdzšinējo medicīnisko un zobārstniecības pieredzi, zobārsta apmeklēšanas un zobu kopšanas paradumiem, vecāku informētību un gimenes sociālekonomiskajiem faktoriem, kā arī bērna personības faktoriem. Tomēr jāṇem vērā, ka pētījuma izlase tika iegūta no respondentiem, kas apmeklēja vienu zobārstniecības iestādi un lielākoties vienu zobārstu. Izlase, iespējams, nav pietiekoši reprezentatīva attiecībā uz respondentu sociālekonomisko stāvokli, zobu ārstēšanas nepieciešamību, kā arī baiļu no zobārsta prevalenci. Tāpēc KPE/kp un BTZ vidējie rādītāji šajā pētîjumā jāinterpretē ar piesardzību.

Autore labprāt turpinātu šķērsgriezuma pētījumus baiļu no zobārsta prevalencei dažādās vecuma grupās, piemēram, 6-7 un 11-12, kā arī 15 gadu vecumā. Tāpat intereses vērts būtu randomizēts kontrolēts pētījums par bērna vecumu pirmās zoba ārstēšanas (plombēšanas vai ekstrakcijas) laikā. Ir vairāki pētījumi par baiḷu no zobārsta saistību ar uzvedības traucējumiem un depresiju, kas varētu būt saistīti ar bailēm un trauksmi zobārstniecībā. 


\section{SECINĀJUMI}

1. CFSS-DS (Bērnu baiḷu pārskata zobārstniecības skala) Latviešu versija ir ticama un valida aptauja bērnu bail̦u no zobārsta novērtēšanai.

2. Bērnu bailes no zobārsta ir saistīti ar bērna iekšējiem (personības un uzvedības) faktoriem:

2.1. bērnu BTZ ir negatīvi saistītas ar bērnu vecumu - kopumā jaunākiem bērniem ir lielākas bailes un trauksme nekā vecākiem bērniem;

2.2. pētījumā nav konstatētas bērnu baiļu no zobārsta atšķirīibas zēniem un meitenēm;

2.3. bērnu bailēm no zobārsta ir pozitīva saistība ar bērnu lielāku emocionalitāti, bet ne ar bērnu aktivitāti un kautrīgumu - emocionālākiem bērniem ir lielākas bailes no zobārsta;

2.4. bērnu vispārējā trauksme ir saistīta ar bērnu bailēm no zobārsta - bērniem ar augstāku trauksmi ir lielākas bailes no zobārsta;

2.5. bērnu bailes no zobārsta nav saistītas ar citu, ar zobārstniecību nesaistītu baiļu skaitu;

2.6. bērnu bailes no zobārsta ir saistîtas ar bērnu uzvedību pie zobārsta - jo lielākas bija bērnu bailes no zobārsta, jo negatīvāka bija bērnu uzvedība pie zobārsta.

3. Bērnu bailes no zobārsta ir saistītas ar ārējiem gímenes (vecāku/informācijas) faktoriem:

3.1. bērnu bailes no zobārsta ir saistītas ar vecāku bailēm no zobārsta - vecākiem ar augstāku baiļu no zobārsta līmeni ir bērni ar lielākām bailēm no zobārsta;

3.2. bērniem, kuru vecāki izmanto tādas pirmsvizītes sagatavošanas metodes kāa ,apsola balvu par labu uzvedību pie zobārsta”, „mierina, ka neko nedarīs un nekas nesāpēs” un „stāsta par savu pieredzi pie zobārsta”, ir lielākas bailes no zobārsta nekā bērniem, kuru vecāki šādas metodes neizmanto; bērniem, kurus vecāki nekā īpaši nesagatavo pirms zobārsta vizītes, kā arī pārrunā bērna mutes kopšanas paradumus ar zobārstniecības speciālistiem, ir zemāks baiḷu no zobārsta līmenis; to vecāku bērniem, kas informāciju par mutes dobuma kopšanu vai bērna sagatavošanu vecāki smeḷas plašsaziņas līdzekḷos un pie draugiem un paziṇām, nevis pie zobārstiem vai zobu higiēnistiem, ir augstāks BTZ līmenis;

3.3. bērnu bailes no zobārsta ir saistītas ar tādiem sociālekonomiskiem/ sociāldemogrāfiskajiem rādītājiem kā ğimenes locekḷu skaits, mājsaimniecības locekḷu skaits, bērnu skaits gimenē, kā arī tēva izglītîba, bet nav atrasta korelācija ne ar ienākumu līmeni, ne vecāku vecumu, ne nodarbinātību, ne laulības statusu. Bērniem, kuriem ir lielāks ğimenes locekḷu un/vai mājsaimniecības locekḷu un/vai 
bērnu skaits ğimenē, kā arī bērniem, kuru tēviem bija augstāka izglīî̄ba, ir mazākas bailes no zobārsta.

4. Bērnu bailes no zobārsta ir saistītas ar ārējiem zobārstniecības faktoriem:

4.1. bērnu bailēm no zobārsta ir saistība ar vecāku nosaukto bērna vecumu (mēnešos) pirmā zobārsta apmeklējuma laikā - bērniem, kuri ir (pēc vecāku norādītās informācijas) agrākā vecumā apmeklējuši zobārstu, ir mazākas bailes no zobārsta; bērnu bailēm no zobārsta nav saistības ar bērnam veiktu zobu apskati, zobu plombēšanu bez anestēzijas un zoba ekstrakciju vietējā anestēzijā;

4.2. bērnu bailēm no zobārsta ir saistība ar iepriekšēju negatīvu pieredzi pie zobārsta bērniem, kuriem ir bijusi iepriekšēja negatīva pieredze zobārstniecības situācijās, ir lielākas bailes no zobārsta;

4.3. bērnu bailes no zobārsta nav saistītas ar hroniskām saslimšanām vai biežāku bērna slimošanu, bet ir saistītas ar bērnu ārsta apmeklējumu biežumu, traumatisku pieredzi pie ārsta un bērna vecumu fiziskas traumas laikā - bērniem, kas apmeklē ārstu vairāk nekā 4 reizes gadā un kam ir bijusi traumatiska pieredze pie ārstiem, kā arī fiziskas traumas agrākā vecumā, ir augstākas bailes no zobārsta.

5. Lielākas bērnu bailes no zobārsta ir saistītas ar augstāku kopējo KPE (KPE + kp) un kp, kā arī lielāku kariozo zobu skaitu $(\mathrm{K}+\mathrm{k}, \mathrm{k}, \mathrm{K})$ visos sakodiena veidos, bet nav saistītas ar plombēto vai ekstrahēto zobu skaitu.

6. Pēc regresijas analīzes model̦iem psihosociālo faktoru blokos bērnu bailes no zobārsta visvairāk izskaidro bērna zobārstniecības pieredzes un attieksmes faktori (bailes un raudāšana pie zobārsta kopā ar grūtībām zobu ārstēšanas laikā, jaunāku bērna vecumu un lielāku KPE), kā arī personības un uzvedības faktori (augstāka vispārējā trauksme, sliktāka bērna uzvedība, ilgāks pārdzīvojums kopā ar lielāku KPE). Nedaudz mazākā mērā tās izskaidro vecāku/informācijas faktori (augstāks vecāku baiļu no zobārsta līmenis kopā ar neatbilstošu bērna sagatavošanu un mierināšanu, jaunāku bērna vecumu un lielāku KPE), kā arī bērna medicīniskās pieredzes un attieksmes faktori (bailīga vai piesardzīga attieksme pret ārstiem kopā ar jaunāku bērna vecumu un lielāku KPE). Ģimenes sociālekonomiskie/sociāldemogrāfískie faktori (lielāks bērnu skaits, mātes vecums un bērna KPE), kā arī zobu kopšanas paradumi un attieksme (lielāks bērna vecums, KPE un zobu tīrīšana kā pienākums) izskaidro bailes no zobārsta ļoti nelielā mērā, savukārt stresam giimenē nav saistības ar bērnu bailēm no zobārsta. 


\section{PRAKTISKĀS REKOMENDĀCIJAS}

1. Informēt ǵimenes ārstus, grūtnieces un jaunās māmiņas, un veicināt bērna pirmo vizīti pie zobārsta atbilstoši daudzu attīstīto valstu vadlīnijām - no bērna pirmā zoba šķilšanās brī̌za līdz 1 gada vecumam, ņemot vērā, ka agrīnas vizītes (apskates) ir saistītas ar mazākām bērnu bailēm no zobārsta.

2. Sniegt vecākiem viegli pieejamu informāciju gan internetā (piemēram, vietnēs www.stomatologijasinstituts.lv, www.tirizobi.lv, www.facebook.com/mantirizobi, www.mammamuntetiem.lv), gan organizēt tieša kontakta kursus jeb t. s. „vecāku skolas” RSU Stomatologijas institūtā par bērnu vecumposmu uztveres īpatnībām saistībā ar zobārstu, par bērna pozitīvu sagatavošanu vizītei pie zobārsta un veidiem, kā nevajadzētu sagatavot bērnu zobārsta apmeklējumam.

3. Veikt jauno speciālistu apmācību darbam ar bērniem psiholoǵiski netraumējošā veidā (apmācības kurss ZF Zobārstniecības un Zobu higiēnistu programmas studentiem „Saskarsme ar pacientiem bērnu zobārstniecībā”, pēcdiploma kursi zobārstiem „Bērns zobārsta kabinetā. Vecuma īpatnības. Bailes no zobārsta un to pārvarēšanas metodes”). 


\section{PUBLIKĀCIJAS UN ZIŅOJUMI PAR PĒTĪJUMA TĒMU}

\section{Publikācijas starptautiski recenzējamos zinātniskos izdevumos}

1. Kronina, L., Rascevska, M., Care, R. Reliability and Validity of Children's Fear Survey Schedule-Dental Subscale (CFSS-DS) Latvian Version. Baltic Journal of Psychology. 2014, 15, 64-72.

2. Kronina, L., Care, R., Rascevska, M. Psycho-social factors correlated with children's dental anxiety. Stomatologija. Baltic Dental and Maxillofacial Journal (iesniegts).

\section{Publikācijas Latvijas recenzējamos zinātniskos izdevumos}

3. Kroniņa, L., Care, R., Raščevska, M. Bailes no zobārsta un to saistība ar pirmās vizītes iemesliem un bērna sagatavošanas veidu zobārsta apmeklējumam. Zinātniskie raksti: 2014. gada medicīnas nozares pētnieciskā darba publikācijas: Internā medicinna. Ķirurǵija. Medicīnas bāzes zinātnes. Stomatologija. Farmācija. Rīgas Stradiña universitāte. - Rīga: Rīgas Stradiṇa universitāte, 2015, 345.-351. lpp.

4. Kroniņa, L., Care, R., Raščevska, M. Četru līdz divpadsmit gadu vecu bērnu bailes no zobārsta un to saistība ar mutes dobuma stāvokli un dažādiem gimenes faktoriem. Zinātniskie raksti: 2013. gada medicīnas nozares pētnieciskā darba publikācijas: Internā medicīna. Kirurgija. Medicīnas bāzes zinātnes. Stomatologìia. Farmācija. Rīgas Stradina universitāte. - Rīga: Rīgas Stradiṇa universitāte, 2014, 403.-410. lpp.

5. Kroniņa, L., Care, R., Raščevska, M. Bērna vecums pirmās ārstēšanas laikā, tā saistība ar bailēm no zobārsta un negatīvu pieredzi. Zinātniskie raksti: 2012. gada medicīnas nozares pētnieciskā darba publikācijas: Internā medicīna. Ķirurgíija. Medicīnas bāzes zinātnes. Stomatologija. Farmācija. Rìgas Stradiņa universitāte. 1. sēj. Rīga: Rīgas Stradiṇa universitāte, 2013, 279.-284. lpp.

\section{Prezentācijas starptautiskās zinātniskās konferencēs}

1. Kronina, L., Care, R., Rascevska, M. "Psychosocial factors correlated with children's dental anxiety in Latvia”, IAPD kongress, Glāzgova, Lielbritānija; stenda referāts, 2015.

2. Kronina, L., Care, R., Rascevska, M. „Dental anxiety related to reasons for child's first dental visit and parent's explanations”, EAPD kongress, Sopota, Polija; mutiska uzstāšanās, 2014.

3. Kronina, L., Care, R., Rascevska, M. „Dental anxiety related to DMFt and other parents’ and children's factors in age 4-12 in Latvia”, IAPD kongress, Seula, Dienvidkoreja; stenda referāts, 2013.

4. Kroniņa, L., Raščevska, M., Care, R. „Baiḷu no zobārsta saistība ar mutes veselību un ǵimenes faktoriem bērniem 4-12 gadu vecumā” - starptautiska konference „Psiholoǵija veselības aprūpē”, Rīga, Latvija; mutiska uzstāšanās, 2013.

5. Kronina, L., Care, R., Rascevska, M. „Dental anxiety related to first dental visit and negative experience in 4-12 years old children in Latvia”, EAPD kongress, Strasbūra, Francija; mutiska uzstāšanās, 2012.

6. Kronina, L., Care, R., Rascevska, M. „Pilot study of different factors related to dental anxiety in 4-12 years old children in Latvia”, IAPD kongress, Atēnas, Grieķija; stenda referāts, 2011.

7. Kronina, L., Care, R., Rascevska, M. „Pilot study of different factors related to dental anxiety in 4-12 years old children in Latvia”, European Conference of Psychological Assessment, Rīga, Latvija; tēzes un stenda referāts, 2011. 


\section{Prezentācijas Latvijas zinātniskās konferencēs}

1. Kroniņa, L., Care, R., Raščevska, M. „Faktori, kas saistīti ar bērnu bailēm un mutes veselību Latvijā”. RSU Zinātniskā konference, mutiska uzstāšanās, 2015.

2. Kroniņa, L. „Bailes - paaudžu mantojums”, mutiska prezentācija LZA sēdē 2015.gada 7.februārī.

3. Kroniņa, L., Care, R., Raščevska, M. „Baiḷu no zobārsta saistība ar bērna vecumu pirmās vizītes laikā, pirmās vizītes iemesliem un bērna sagatavošanas veidu”, RSU Zinātniskā konference, tēzes un mutiska uzstāšanās, 2014.

4. Kroniņa, L. „Bērnu un vecāku bailes no zobārsta: cēloṇi, sekas un risinājumi”, mutiska uzstāšanās Mutes veselības konferencē „Pašvaldības atbalsts mutes veselības saglabāšanā", 2014. gada 28.martā.

5. Kroniņa, L. „Bērnu un vecāku bailes no zobārsta”, mutiska uzstāšanās LZHA sēdē, 2014. gada 8.martā.

6. Kroniņa, L., Care, R., Raščevska, M. „Baiļu no zobārsta saistība ar mutes veselību un gimenes faktoriem bērniem 4-12 gadu vecumā”, RSU Zinātniskā konference, tēzes un mutiska uzstāšanās, 2013.

7. Kroniņa, L., Care, R., Raščevska, M. „Bērna vecums pirmās ārstēšanas laikā, tā saistība ar bailēm no zobārsta un negatīvu pieredzi”, RSU Zinātniskā konference, tēzes un mutiska uzstāšanās", 2012.

8. Kroniņa, L. „Bērna pirmā vizīte pie zobārsta, bailes no zobārsta, zobārstu izmantotās metodes - vadlīnijas un realitāte", mutiska uzstāšanās LZA sēdē, 2013. gada 6.aprīlī.

9. Kroniņa, L., Care, R., Raščevska, M. „Pilotpētījums par faktoriem, kas saistīti ar bērnu bailēm no zobārsta 4-12 gadus veciem bērniem Latvijā̄", RSU Zinātniskā konference, tēzes un mutiska uzstāšanās", 2011.

\section{Tēzes starptautiskās zinātniskās konferencēs}

1. Kronina, L., Care, R., Rascevska, M. "Factors correlated with children's dental anxiety in Latvia”, IAPD kongress, Glāzgova, Lielbritānija, 2015; tēzes, 122.lpp.

2. Kronina, L., Care, R., Rascevska, M. „Dental anxiety related to reasons for child's first dental visit and parent's explanations”, EAPD kongress, Sopota, Polija, 2014; tēzes, 42.lpp.

3. Kronina, L., Care, R., Rascevska, M. „Dental anxiety related to DMFt and other parents’ and children's factors in age 4-12 in Latvia”, IAPD kongress, Seula, Dienvidkoreja, 2013; tēzes, 102.lpp.

4. Kronina, L., Care, R., Rascevska, M. „Dental anxiety related to first dental visit and negative experience in 4-12 years old children in Latvia", EAPD kongress, Strasbūra, Francija, 2012, tēzes, 31.lpp.

5. Kronina, L., Care, R., Rascevska, M. „Pilot study of different factors related to dental anxiety in 4-12 years old children in Latvia”, IAPD kongress, Atēnas, Grieksija, 2011; tēzes, 187.lpp.

\section{Tēzes Latvijas zinātniskās konferencēs}

1. Kroniņa, L., Care, R., Raščevska, M. „Faktori, kas saistīti ar bērnu bailēm un mutes veselību Latvijā̄”. RSU Zinātniskā konference, 2015; tēzes, 300.lpp.

2. Kroniņa, L., Care, R., Raščevska, M. „Baiḷu no zobārsta saistība ar bērna vecumu pirmās vizītes laikā, pirmās vizītes iemesliem un bērna sagatavošanas veidu”, RSU Zinātniskā konference, 2014; tēzes, 133.lpp. 
3. Kroniņa, L., Care, R., Raščevska, M. „Baiļu no zobārsta saistība ar mutes veselību un gimenes faktoriem bērniem 4-12 gadu vecumā”, RSU Zinātniskā konference, 2013; tēzes, 98.lpp.

4. Kroniņa, L., Care, R., Raščevska, M. „Bērna vecums pirmās ārstēšanas laikā, tā saistība ar bailēm no zobārsta un negatīvu pieredzi”, RSU Zinātniskā konference, 2012; tēzes, 115.lpp.

5. Kroniņa, L., Care, R., Raščevska, M. „Pilotpētījums par faktoriem, kas saistīti ar bērnu bailēm no zobārsta 4-12 gadus veciem bērniem Latvijā”, RSU Zinātniskā konference, 2011; tēzes, 117. lpp. 


\section{LITERATŪRAS SARAKSTS}

1. AAPD Guideline on Perinatal and Infant Oral Health. AAPD Reference Manual. 2016, 38(6), 150-154.

2. Akbay-Oba, A., Dulgergil, C. T., Sonmez, I. S. Prevalence of dental anxiety in 7- to 11-year-old children and its relationship to dental caries. Medical Principles and Practice. 2009, 18, 453-457.

3. Alfayad, D. W., Al-Hadithy, E. M. R. Dental anxiety and its relation to serum cortisol level before dental surgical treatment. Anbar Medicine Journal. 2012, 10(1), 35-40.

4. Alvesalo, I., Murtomaa, H., Milgrom, P., Honkanen, A., Karjalainen, M., Tay, K. M. The Dental Fear Survey Schedule: a study with Finnish children. International Journal of Paediatric Dentistry. 1993, 3, 193-198.

5. Aminabadi, N. A., Deljavan, A. S., Jamali, Z., Azar, F. P., Oskouel, S. G. The influence of parenting style and child temperament on child-parent-dentist interactions. Pediatric Dentistry. 2015, 37(4), 342-347.

6. Armfield, J. M. Cognitive vulnerability: a model of the etiology of fear. Clinical Psychology Review. 2006, 26, 746-768.

7. Armfield, J. M., Stewart, J. F., Spencer, A. J. The vicious cycle of dental fear: exploring the interplay between oral health, service utilization and dental fear. BMC Oral Health. 2007, 7, 1.

8. Armfield, J. M. A preliminary investigation of the relationship of dental fear to other specific fears, general fearfulness, disgust sensitivity and harm sensitivity. Community Dentistry and Oral Epidemiology. 2008, 36, 128-136.

9. Armfield, J. M., Slade, G. D., Spencer, A.J. Cognitive vulnerability and dental fear. BMC Oral Health. 2008, 8(2), 1-11.

10. Armfield, J. M., Slade, G. D., Spencer, A. J. Dental fear and adult oral health in Australia. Community Dentistry and Oral Epidemiology. 2009, 37, 220-230.

11. Armfield, J. M., Milgrom, P. A clinician guide to patients afraid of dental injections and numbness. SAAD Digest. 2011, 27, 33-39.

12. Arnrup, K., Broberg, A., Berggren, U., Bodin, L. Lack of cooperation in pediatric dentistry - the role of child personality characteristics. Pediatric Dentistry. 2002, 24(2), 119-128.

13. Arnrup, K., Broberg, A., Berggren, U., Bodin, L. Temperamental reactivity and negative emotionality in uncooperative children referred to specialized paediatric dentistry compared to children in ordinary dental care. International Journal of Paediatric Dentistry. 2007, 17, 419429.

14. Auerbach, S. M., Martelli, M. F., Mercuri, L. G. Anxiety, information, interpersonal impacts, and adjustment to a stressful health care situation. Journal of Personality and Social Psychology. 1983, 44(6), 1284-1296.

15. Bandura, A. Social learning theory. New York: General Learning Press, 1971.

16. Beaton, L., Freeman, R., Humphris, G. Why are people afraid of the dentist? Observations and explanations. Medical Principles and Practice. 2014, 23(4), 295-301.

17. Bedi, R., Sutcliffe, P., Donnan, P., Barrett, N., McConachie, J. Dental caries experience and prevalence of children afraid of dental treatment. Community Dentistry and Oral Epidemiology. 1992, 20, 368-371.

18. Beena, J. P. Dental subscale of children's fear survey Schedule and dental caries prevalence. European Journal of Dentistry. 2013, 7, 181-185.

19. Berggren, U., Meynert, G. Dental fear and avoidance: causes, symptoms, and consequences. Journal of American Dental Association. 1984, 109(2), 247-251.

20. Berggren, U. General and specific fears in referred and self-referred adult patients with extreme dental anxiety. Behavior Research and and Therapy. 1992, 30, 395-401.

21. Bērzin̦a, S. Kariesa un periodonta patologiju izplatība bērniem un pusaudžiem Latvijā: promocijas darba kopsavilkums, medicīnas nozares zobārstniecības specialitāte. Rīga: Rīgas Stradiņa universitāte, 2004.

22. Broome, M. E., Bates, T. A., Lillis, P. P, McGahee, T. W. Children's medical fears, coping behaviour patterns and pain perceptions during a lumbar puncture. European Journal of Cancer Care. 1994, 3, 31-38. 
23. Brukiene, V., Aleksejuniene, J., Balciuniene, I. Is dental treatment experience related to dental anxiety? A cross-sectional study in Lithuanian adolescents. Stomatologija, Baltic Dental and Maxillofacial Journal. 2006, 8(4), 108-115.

24. Buchanan, H., Niven, N. Self-report treatment techniques used by dentists to treat dentally anxious children: a preliminary investigation. International Journal of Paediatric Dentistry. 2003, 13(1), 9-12.

25. Buss, A. H., Plomin, R. A temperament theory of personality development. Oxford: WileyInterscience, 1975.

26. Caglar, E., Sandalli, N., Kirant, B., Kuscu, O. O. Evaluation of words in child-paediatric dentist communication. European Journal of Paediatric Dentistry. 2015, 16(3), 236-238.

27. Carrillo-Diaz, M., Crego, A., Armfield, J. M., Romero-Maroto, M.. Treatment experience, frequency of dental visits, and children's dental fear: a cognitive approach. European Journal of Oral Sciences. 2012, 120, 75-81.

28. Chadwick, B., Hosey, M. T. Child taming: how to manage children in dental practice. London: Quintessence Publishing, 2003.

29. Chellappah, N. K., Vignehsa, H., Milgrom, P., Lo, G. L. Prevalence of dental anxiety and fear in children in Singapore. Community Dentistry and Oral Epidemiology. 1990, 18, 269-271.

30. Cohen, M. E. Dental anxiety and DMFS status: associations within a US naval population versus differences between groups. Community Dentistry and Oral Epidemiology. 1985, 13, 75-78.

31. Corah, N. L. Development of a Dental Anxiety Scale. Journal of Dental Research. 1969, 48, 596.

32. Costa, N. M., Weems, C. F. Maternal and child anxiety: do attachment beliefs or children's perceptions of maternal control mediate their association? Social Development. 2005, 14(4), 574590.

33. Cuthbert, M. I., Melamed, B. G. A screening device: children at risk for dental fears and management problems. Journal of Dentistry for Children. 1982, 49, 432-436.

34. Dadds, M. R., Barrett, P. M. Family processes in child and adolescent anxiety and depression. Behaviour Change. 1996, 13(4), 231-239.

35. Davey, G. C. L.. Dental phobias and anxieties: evidence for conditioning processes in the acquisition and modulation of a learned fear. Behaviour Research and Therapy. 1989, 27, 51-58.

36. de Jongh, A., Bongaarts, G., Vermeule, I., Visser, K., de Vos, P., Makkes, P. Blood-injuryinjection phobia and dental phobia. Behaviour Research and Therapy. 1998, 36, 971-982.

37. de Jongh, A., Fransen, J., Oosterink-Wubbe, F., Aartman, I. Psychological trauma exposure and trauma symptoms among individuāls with high and low levels of dental anxiety. European Journal of Oral Sciences. 2006, 114, 286-292.

38. de Menezes Abreu, D. M., Leal, S. C., Mulder, J., Frencken, J. E. Patterns of dental anxiety in children after sequential dental visits. European Archives of Paediatric Dentistry. 2011, 12(6), 298-302.

39. Dogan, M. C., Yazicioglu, I, Antmen, B. Anxiety and pain during dental treatment among children with haemophilia. European Journal of Paediatric Dentistry. 2013, 14(4), 284-288.

40. Edmunds, R., Buchanan, H. Cognitive vulnerability and the aetiology and maintenance of dental anxiety. Community Dentistry and Oral Epidemiology. 2012, 40, 17-25.

41. Eitner, S., Wichmann, M., Paulsen, A., Holst, S. Dental anxiety - an epidemiological study on its clinical correlation and effects on oral health. Journal of Oral Rehabilitation. 2006, 33, 588-593.

42. Eley, T. C. Contributions of behavioral genetics research: Quantifying genetic, shared environmental and non-environmental influences. In: The developmental psychopatology of anxiety. M. W. Vasey, M. R. Dadds, eds. Oxford: Oxford University Press, 2001.

43. Eysenck, H. J. The biological bases of personality. Springfield: Thomas, 1967.

44. Eysenck, M. W. Attention and arousal: cognition and performance. Berlin Heidelberg: Springer Verlag, 1982.

45. Field, A. P., Lawson, J. Fear information and the development of fears during childhood: effects on implicit fear responses and behavioural avoidance. Behaviour Research and Therapy. 2003, 41(11), 1277-1293.

46. Field, A. P., Lawson, J. The verbal information pathway to fear and subsequent causal learning in children. Cognition and Emotion. 2008, 22(3), 459-479.

47. Fisak Jr., B., Grills-Taquechel, A. E. Parental modeling, reinforcement, and information transfer: risk factors in the development of child anxiety? Clinical Child and Family Psychology. 2007, 10(3), 213-231. 
48. Flury, T., Aebi, C., Donati, F. Febrile seizures and aprental anxiety: does information help? Swiss Medical Weekly. 2001, 131(37-38), 556-560.

49. Folayan, M. O., Adekoya-Sofowora, C. A., Otuyemi, O. D., Ufomata, D. Parental anxiety as a possible predisposing factor to child dental anxiety in patients seen in a suburban dental hospital in Nigeria. International Journal of Pediatric Dentistry. 2002, 12(4), 255-259.

50. Folayan, M. O., Idehen, E. E., Ojo, O. O. The modulating effect of culture on the expression of dental anxiety in children: a literature review. International Journal of Pediatric Dentistry. 2004, $14,241-245$.

51. Folayan, M. O., Idehen, E. E., Ojo, O. O. Dental anxiety in a subpopulation of African children: parents ability to predict and its relation to general anxiety and behaviour in the dental chair. European Journal of Paediatric Dentistry. 2004, 1, 19-23.

52. Folayan, M. O., Idehen, E. E. Effect of information on dental anxiety and behaviour ratings in children. European Journal of Paediatric Dentistry. 2004, 3, 147-150.

53. Folayan, M. O., Idehen, E. E., Ojo, O. O. Identified factors in child-dentist relationship important for the management of dental anxiety in Nigerian children. European Journal of Paediatric Dentistry. 2004, 4, 225-232.

54. Fox, C., Newton, J. T. A controlled trial of the impact of exposure to positive images of dentistry on anticipatory dental fear in children. Community Dentistry and Oral Epidemiology. 2006, 34, 455-459.

55. Fox, S. The social life of health information. PewResearchCenter, 2011.

56. Frankl, S. N., Schiere, F. R., Fogels, H. R. Should the parent remain with the child in the dental operatory? Journal of Dentistry for Children. 1962, 29, 150-163.

57. Fredrickson, B. L., Branigan, C. Positive emotions broaden the scope of attention and thoughtaction repertoires. Cognition \& Emotion. 2005, May 1, 19(3), 313-332.

58. Freeman, R. A fearful child attends: a psychoanalytic explanation of children's responses to dental treatment. International Journal of Pediatric Dentistry. 2007, 17, 407-418.

59. Freids Z. Ievadlekcijas psihoanalīzē. Rīga: Zvaigzne ABC, 2007.

60. Freidson, E., Feldman, J. J. The public looks at dental care. Journal of American Dental Association. 1958, 57, 325.

61. Freud A. The concept of the rejecting mother. In: Anna Freud Selected Writings. R. Ekins, R. Freeman, eds. London: Penguin Books, 1998.

62. Frick, P. J., Sirverthorn, P., Evans, C. Assessment of childhood anxiety using structured interviews: patterns of agreement among informants and association with maternal anxiety. Psychological Assessment. 1994, 6(4), 372-379.

63. Fuentes, D., Gorenstein, C., Hu, L. W. Dental anxiety and trait anxiety: an investigation of their relationship. British Dental Journal. 2009, 206, E17.

64. Greenbaum, P. E., Turner, C., Cook, E. W., Melamed, B. G. Dentists'voice control: effects on children's disruptive and affective behavior. Health Psychology. 1990, 9(5), 546-558.

65. Gustafsson, A., Arnrup, K., Broberg, A., Bodin, L. Psychosocial concomitants to dental fear and behaviour management problems. International Journal of Pediatric Dentistry. 2007, 17, 449459.

66. Gustafsson, A., Arnrup, K., Broberg, A. G., Bodin, L., Berggren, U. Child dental fear as measured with the Dental Subscale of the Children's Fear Survey Schedule: the impact of referral status and type of informant (child versus parent). Community Dentistry and Oral Epidemiology. 2010, 38, 256-266.

67. Gustafsson, A., Broberg, A., Bodin, L., Berggren, U., Arnrup, K. Dental behaviour management problems: the role of child personal characteristics. International Journal of Pediatric Dentistry. 2010, 20, 242-253.

68. Halonen, H., Salo, T., Hakko, H., Rasanen, P. Association of dental anxiety to personality traits in a general population sample of Finnish university students. Acta Odontologica Scandinavica. 2012, 70, 96-100.

69. Hamburg, D., Hamburg, B. Learning to live together. Oxford: Oxford University Press, 2004.

70. Harman, K., Lindsey, S., Adewami, A., Smith, P. An investigationof language used by children to describe discomfort expected and experienced during dental treatment. International Journal of Pediatric Dentistry. 2005, 15, 319-326.

71. Hittner, J. B., Hemmo, R. Psychosocial predictors of dental anxiety. Journal of Health Psychology. 2009, 14(1), 53-59. 
72. Hettema, J. M., Neale, M. C., Kendler, K. S. A review and meta-analysis of the genetic epidemiology of anxiety disorders. The American Journal of Psychiatry. 2001, 158(10), 15681578.

73. Hoeft, K. S., Barker, J. C., Masterson, E. E. Maternal Beliefs and Motivations for First Dental Visit by Low-Income Mexican-American Children in California. Pediatric Dentistry. 2011, 33(5), 392-398.

74. Hollis, A., Willcoxson, F., Smith, A., Balmer, R. An investigation into dental anxiety amongst paediatric cardiology patients. International Journal of Pediatric Dentistry. 2015, 25, 183-190.

75. Holst, A., Schroder, U. Ek, L., Halonsten, A. L., Crossner, C. G. Prediction of behavior management problems in children. Scandinavian Journal of Dental Research. 1988, 96, 457-465.

76. Horney, K. The neurotic personality of our time. London: Routledge, 1999.

77. Hummel, R., Gross, A. Socially anxious children: an observational study of parent-child interaction. Child \& Family Behavior Therapy. 2001, 23, 19-41.

78. Humphris, G., Morrison, T., Linsay, S. The Modified Dental Anxiety Scale: validation and United Kingdom norms. Community Dental Health. 1995, 12, 143-150.

79. Humphris, G., King, K. The prevalence of dental anxiety across previous distressing experiences. Journal of Anxiety Disorders. 2011, 25, 232-236.

80. Inzana, C. M., Driskell, J. E., Salas, E., Johnston, J. H. Effects of preparatory information on enhancing performance under stress. Journal of Applied Psychology. 1996, 81(4), 429-435.

81. Ismail, A. I., Sohn, W., Tellez, M., Amaya, A., Sen, A., Hasson, H., et al.. The International Caries Detection and Assassment System (ICDAS): an integrated system for measuring dental caries. Community Dentistry and Oral Epidemiology. 2007, 35, 170-178.

82. Jaakkola, S., Lahti, S., Raiha, H., Saarinen, M., Tolvanen, M., Aromaa, M., et al. Dental fear affects adolescent perception of interaction with dental staff. European Journal of Oral Sciences. 2014, 122, 339-345.

83. Jackson, C., Lindsay, S. Reducing anxiety in new dental patients by means of leaflets. Brittish Dental Journal. 1995, 179(5), 163-167.

84. Jafarzadeh, M., Keshani, F., Ghazavi, Z., Keshani, F. Reviewing the parental standpoint about origin of the dental fear in children referred to dentistry centers of Isfahan University of Medical Sciences. Iranian Journal of Nursery and Midwifery Research. 2011, 16(1), 133-139.

85. Jerjes, W., Hopper, C., Kumar, M., Upile, T., Madland, G., Newman, S., et al. Psychological intervention in acute dental pain: review. British Dental Journal. 2007, 202(6), 337-343.

86. Karjalainen, S., Olak, J., Söderling, E., Pienihäkkinen, K., Simell, O. Frequent exposure to invasive medical care in early childhood and operative dental treatment associated with dental apprehension of children at 9 years of age. European Journal of Paediatric Dentistry. 2003, 4, 186-190.

87. Kent, G. Memory of dental pain. Pain. 1985, 21(2), 187-194.

88. Kent, G. G., Blinkhorn, A. S. The psychology of dental care. 2nd ed. Oxford: Wright, 1991.

89. Klaassen, M. A., Veerkamp, J. S. J., Hoogstraten, J. Dental fear, communication, and behavioural management problems in children reffered for dental problems. International Journal of Paediatric Dentistry. 2007, 17, 469-477.

90. Kleinknecht, R. A., Bernstein, D. A. The assessment of dental fear. Behaviour Therapy. 1978, 9, 626-634.

91. Klingberg, G. Reliability and validity of the Swedish version of the Dental Subscale of the Children’s Fear Survey Schedule, CFSS-DS. Acta Odontologica Scandinavica. 1994, 52, 255256.

92. Klingberg, G., Berggren, U., Noren, J. G. Dental fear in an urban Swedish child population: prevalence and concomittant factors. Community Dental Health. 1994, 11, 208-214.

93. Klingberg, G., Berggren, U., Carlsson, S. G., Noren, J. G. Child dental fear: cause-related factors and clinical effects. European Journal of Oral Science. 1995, 103, 405-412.

94. Klingberg, G., Broberg, A. Dental fear/anxiety and dental behaviour management problems in children an adolescents: a review of prevalence and concomitant psychological factors. International Journal of Pediatric Dentistry. 2007, 17, 391-406.

95. Klingberg, G., Raadal, M., Arnrup, K. Dental fear and behavior management problems. In: Paediatric dentistry: a clinical approach. 2nd ed. Goran Koch, Sven Poulsen, eds. Oxford: Blackwell Publishing, 2009. 
96. Krain, A. L., Kendall, P. C. The role of parental emotional distress in parent report of child anxiety. Journal of Clinical Child Psychology. 2000, 29(3), 328-335.

97. Krikken, J. B., Van Wijk, A. J., ten Cate, J. M., Veerkamp, J. S. J. Measuring dental fear using the CFSS-DS. Do children and parents agree? International Journal of Paediatric Dentistry. 2013, 23(2), 94-100.

98. Krikken, J. B., Van Wijk, A. J., ten Cate, J. M., Veerkamp, J. S. J. Child dental anxiety, parental rearing style and referral status of children. Community Dental Health. 2012, 29, 289-292.

99. Kruger, E., Thompson, W. M., Poulton, R., Davies, S., Brown, R. H., Silva, P. A. Dental caries and changes in dental anxiety in late adolescence. Community Dentistry and Oral Epidemiology. 1998, 26, 355-359.

100. Kuenkel, A. Kinder- und Jugendpsychologie in der zahnaerztlichen praxis. Hannover: Schluetter, 2000.

101. Lahti, S., Luoto, A. Significant relationship between parental and child dental fear. Evidence Based Dentistry. 2010, 11(3), 77.

102. Lang, P. Stimulus control, response control and desensitization of fear. In: Learning approaches to therapeutic behaviour change. D. Lewis D., ed. Chicago: Aldine Press, 1970.

103. Lara, A., Crego, A., Romero-Maroto, M. Emotional contagion of dental fear to children: the fathers'mediating role in parental transfer of fear. International Journal of Paediatric Dentistry. 2012, 22, 324-330.

104. Lazarus, R. S. Progress on a cognitive-motivational-relational theory of emotion. American Psychologist. 1991, 46(8), 819-834.

105. Leahy, R. L., McGinn, L. K., Busch, F. N., Milrod, B. L. Anxiety disorders. In: Oxford Textbook of Psychoterapy. Glen O. Gabbard, Judith S. Beck, Jeremy Holmes, eds. Oxford: Oxford University Press, 2006.

106. Lee, C. Y., Chang, Y. Y., Huang, S. T. The clinically related predictors of dental fear in Taiwanese children. International Journal of Pediatric Dentistry. 2008, 18, 415-422.

107. Liddell, A., Locker, D. Gender and age diferences in attitudes to dental pain and dental control. Community Dentistry and Oral Epidemiology. 1997, 25(4), 314-318.

108. Locker, D., Shapiro, D., Liddell, A. Negative dental experiences and their relationship to dental anxiety. Community Dental Health. 1996, 13(2), 86-92.

109. Locker, D., Liddell, A., Dempster, L., Shapiro, D. Age of onset of dental anxiety. Journal of Dental Research. 1999, 78(3), 790-796.

110. Lundgren, J., Elfstrom, M. L., Berggren, U. The relationship between temperament and fearfulness in adult dental phobic patients. International Journal of Pediatric Dentistry. 2007, 17, 460-468.

111. Luoto, A., Tolvanen, M., Rantavuori, K., Pohjola, V., Lahti, S. Can parents and children evaluate each other's dental fear? European Journal of Oral Sciences. 2010, 118, 254-258.

112. Majstorovic, M., Skrinjaric, I., Glavina, D., Szirovicza, L. Factors Predicting a Child's Dental Fear. Collegium Antropologicum. 2001, 25(2), 493-500.

113. Majstorovic, M., Veerkamp, J. S. J., Skrinjaric, I. Reliability and validity of measures used in assessing dental anxiety in 5- to 15-year-old Croatian children. European Journal of Paediatric Dentistry. 2003, 4, 197-202.

114. Majstorovic, M., Veerkamp, J. S. J. Developmental changes in dental anxiety in a normative population of Dutch children. European Journal of Paediatric Dentistry. 2005, 1, 30-34.

115. Mayou, R. A., Smith, K. A. Posttraumatic symptoms following medical illness and treatment. Journal of Psychosomatic Research. 1997, 43(2), 121-123.

116. McNeil, D. W., Helfer, A. J., Weaver, B. D., Graves, R. W., Kyle, B. N., Davis, A. M. Memory of pain and anxiety associated with tooth extraction. Journal of Dental Research. 2011, 90(2), 220-224.

117. Meera, R., Muthu, M. S., Phanibabu, M., Rathnaprabhu, V. First dental visit of a child. Journal of the Indian Society of Pedodontics and Preventive Dentistry. 2008, 26(6), 68-71.

118. Mehrstedt, M., Tonnies, S., Eisentraut, I. Dental fears, health status, and quality of life. Anesthesia Progress. 2004, 51, 90-94.

119. Melamed, B. G., Bennett, C. G., Jerrell, G., Ross, S. L., Bush, J. P., Hill, C., et al. Dentists' behavior management as it affects compliance and fear in pediatric patients. Journal of American Dental Association. 1983, 106(3) 324-330. 
120. Mileva, S. P., Kondeva, V. K. Age et and reasons for the first dental visit. Folia Medica. 2010, 52(4), 56-61.

121. Milgrom, P., Mancl, L., King, B., Weinstein, P. Origins of childhood dental fear. Behavior Research and Therapy. 1995, 33(3), 313-319.

122. Milgrom, P., Coldwell, S. E., Getz, T., Weinstein, P., Ramsay, D. S. Four dimensions of fear of dental injections. Journal of American Dental Association. 1997, 128(6), 756-766.

123. Milsom, K. M., Tickle, M., Humphris, G. M., Blinckhorn, A. S. The relationship between anxiety and dental treatment experience in 5-year-old children. British Dental Journal. 2003, 194, 503506.

124. Morgan, G. E. How childhood fears toward dentistry can be controlled. Journal of American Dental Association. 1940, 27, 766-768.

125. Muris, P., Steerneman, P., Merckelbach, H., Meesters, C. The role of parental fearfulness and modeling in children's fear. Behaviour Research and Therapy. 1996, 34(3), 265-268.

126. Murray, P., Liddell, A., Donohue, J. A longitudinal study of the contribution of dental experence to dental anxiety in children between 9 and 12 years of age. Journal of Behavioral Medicine. 1989, 12(3), 309-320.

127. Nakai, Y., Hirakawa, T., Milgrom, P., Coolidge, T., Masahiro, H., Mori, Y., Chicako, I., et al. The Children's Fear Survey Schedule - Dental Subscale in Japan. Community Dentistry and Oral Epidemiology. 2005, 33(3), 196-204.

128. Neverlien, P. O., Backer-Johnsen, T. Optimism-pessimism dimension and dental anxiety in children aged 10 - 12 years. Community Dentistry and Oral Epidemiology. 1991, 19(6), 342-346.

129. Ng, S. K. S., Chau, A. W. L., Leung, W. K. The effect of pre-operative information in relieving anxiety in oral surgery patients. Community Dentistry And Oral Epidemiology. 2004, 32(3), 227235.

130. Oktay, E. A., Kocak, M. M., Sahinkesen, G., Topcu, F. T. The role of age, gender, education and experiences on dental anxiety. Gulhan Medical Journal. 2009, 51, 145-148.

131. Olumide, F., Newton, J. T., Dunne, S., Gilbert, D. B. Anticipatory information in children visiting the dentist: lack of effect of preparatory information. International Journal of Pediatric Dentistry. 2009, 19, 338-342.

132. Oosterink, F. M. D., de Jongh, A., Aartman, I. H. A. What are people afraid of during dental treatment? Anxiety-provoking capacity of 67 stimuli characteristic of the dental setting. European Journal of Oral Sciences. 2008, 116, 44-51.

133. Oosterink, F. M. D., de Jongh, A., Hoogstraten, J. Prevalence of dental fear and phobia relative to other fear and phobia subtipes. European Journal of Oral Sciences. 2009, 117, 135-143.

134. Oosterink, F. M. D., de Jongh, A., Aartman, I. H. A. Negative events and their potential risk of precipitating pathological forms of dental anxiety. Journal of Anxiety Disorders. 2009, 23, 451457.

135. Öhman, A., Flykt, A., Esteves, F. Emotion drives attention: detecting the snake in the grass. Journal of Experimental Psychology General. 2001, 130, 466-478.

136. Öst, L. G. Age of onset in different phobias. Journal of Abnormal Psychology. 1987, 96, $223-$ 229.

137. Pai, R., Mandroli, P., Benni, D., Pujar, P. Prospective analysis of factors associated with dental behavior management problems, in children aged 7-11 years. Journal of Indian Society of Pedodontics and Preventive Dentistry, 2015, 33, 312-318.

138. Paryab, M., Hosseinbor, M. Dental fear and behavioral problems: a study of prevalence and related factors among a group of Iranian children aged 6-12. Journal of Indian Society of Pedodontic and Preventive Dentistry. 2013, 31, 82-86.

139. Patel, H., Reid, C., Wilson, K., Girdler, N. M. Inter-rater agreement between children's selfreported and parents' proxy-reported dental anxiety. British Dental Journal. 2015, 218, E6.

140. Peretz, B., Nazarian, Y., Bimstein, E. Dental anxiety in a students'paediatric dental clinic: children, parents and students. International Journal of Paediatric Dentistry. 2004, 14, 192-198.

141. Piažē, Ž. Bērna intelektuālā attīstība. Rīga: Pētergailis, 2002.

142. Pohjola, V., Lahti, S., Vehkalahti, M. M., Tolvanen, M., Hausen, H. Association between dental fear and dental attendance among adults in Finland. Acta Odontologica Scandinavica. 2007, 65(4), 224-230. 
143. Pohjola, V., Rekola, A., Kunttu, K., Virtanen, J. Association between dental fear and oral habits and treatment need among university students in Finland: a national study. BMC Oral Health. 2016, 16, 26.

144. Poulsen, S. The child's first dental visit. International Journal of Paediatric Dentistry. 2003, 13, 264-265.

145. Poulton, R., Waldie, K. E., Thomson, W. M., Locker, D. Determinants of early- vs late-onset dental fear in a longitudinal epidemiological study. Behaviour Research and Therapy. 2001, 39, 777-785.

146. Raadal, M., Milgrom, P., Weinstein, P., Mancl, L., Cauce, A. M. The prevalence of dental anxiety in children from low-income families and its relationship to personality traits. Journal of Dental Research. 1995, 74, 1439-1443.

147. Raadal, M., Strand, G. V., Amarante, E. C., Kvale, G. Relationship between caries prevalence at 5 years of age and dental anxiety at 10. European Journal of Paediatric Dentistry. 2002, 1, 22 26.

148. Rachman, S. The conditioning theory of fear-acquisition: a critical examination. Behaviour Research and Therapy. 1977, 15, 375-387.

149. Rantavuori, K., Zerman, N., Ferro, R., Lahti, S. Relationship between children’s first dental visit and their dental anxiety in the Veneto Region of Italy. Acta Odontologiska Scandinavica. 2002, 60, 297-300.

150. Rantavuori, K., Tolvanen, M., Hausen, H., Lahti, S., Seppä, L.. Factors associated with different measures of dental fear among children at different ages. Journal of Dentistry for Children. 2009. 76(1), 13-19.

151. Ray, J., Wide-Boman, U., Bodin, L., Berggren, U., Lichtenstein, P., Broberg, A. Heritability of dental fear. Journal of Dental Research. 2010, 89(3), 297-301.

152. Rothbart, M. K., Ahadi, S. A., Hershey, K. L., Fisher, P. Investigations of temperamenta t three to seven years: the Children's Behavior Questionnaire. Child Development, 2001, 72(5), 1394-1408.

153. Saag, M., Olak, J. Impact of mothers' health attitudes on dental health of their children. EPMA Journal. 2014, 5(1), A111.

154. Samorodnitzky, G., Levin, L. Self-assessed dental status, oral behavior, DMF, and dental anxiety. Journal of Dental Education. 2005, 69(12), 1385-1389.

155. Sarnat, H., Arad, P., Hanauer, D., Shohami, E. Communication strategies used during pediatric dental treatment: a pilot study. Pediatric Dentistry. 2001, 23(4), 337-342.

156. Schuller, A. A., Willumsen, T., Holst, D. Are there differences in oral health and oral health behavior between individuals with high and low dental fear? Community Dentistry and Oral Epidemiology. 2003, 31, 116-121.

157. Schuurs, A. H. B., Duivenvoorden, H. J., Thoden van Velzen, S. K., Verhage, F., Makkes, P. C., Eijkman, M. A. J. Psychological correlates of dental anxiety. Community Dentistry and Oral Epidemiology. 1986, 14, 69-72

158. Schuurs, A. H. B., Duivenvoorden, H. J., Makkes, P. C., Thoden van Velzen, S. K., Verhage, F. Personality traits of patients suffering extreme dental anxiety. Community Dentistry and Oral Epidemiology. 1988, 16(1), 38-41.

159. Seligman, M. E. P. Phobias and preparedness. Behavior Therapy, 1971, 307-320.

160. Shapiro, M., Melmed, R. N., Sgan-Cohen, H., Eli, I., Parush, S. Behavioural and psysiological effect of dental environment sensory adaptation on children's dental anxiety. European Journal of Oral Sciences. 2007, 115, 479-483.

161. Shin, W. K., Braun, T. M., Inglehart, M. R. Parents' dental anxiety and oral health literacy: effects on parents'and children's oral health-related experiences. Journal of Public Health Dentistry. 2014, 74, 195-201.

162. Shindova, M., Belcheva, A., Mateva, N. Factors in dental environment related to development od child dental fear and parent-child agreement on its evaluation. Medicine. 2014, 1, 91-95.

163. Skaret, E., Raadal, M., Berg, E., Kvale, G. Dental anxiety among 18-year-olds in Norway. Prevalence and related factors. European Journal of Oral Sciences. 1998, 106, 835-843.

164. Smith, P. A., Freeman, R. Remembering and repeating childhood dental treatment experiences: parents, their children, and barriers to dental care. International Journal of Paediatric Dentistry. 2010, 20, 50-58. 
165. Spafford, P., von Baeyer, C. L., Expected and reported pain in children undergoing ear piercing: a randomized trial of preparation by parents. Behaviour Research and Therapy. 2002, 40(3), 251266.

166. Spielberger, C. D. Anxiety and behaviour . NewYork: AcademicPress, 1966.

167. Stenebrand, A., Wide-Boman, U., Hakeberg, M. General fearfulness, attitudes to dental care, and dental anxiety in adolescents. European Journal of Oral Sciences. 2013, 121, 252-257.

168. Sternberg, R. J. Cognitive psychology. Forthworth: Harcourt Brace College Publisher, 1996.

169. Suprabha, B. S., Rao, A., Choudhary, S., Shenoy, R. Child dental fear and behavior: The role of environmental factors in a hospital cohort. Journal of Indian Society of Pedodontics and Preventive Dentistry. 2011, 29, 95-101.

170. Sussman, N. M., Rosenfeld, H.M. Influence of culture, language, and sex on conversional distance. Journal of Personality and Social Psychology. 1982, 42(1), 66-74.

171. Taani, D. Q., El-Qaderi, S. S., Abu Alhaija, E. S. Dental anxiety in children and its relationship to dental caries and gingival condition. International Journal of Dental Hygiene. 2005, 3(2), 83-87.

172. ten Berge, M., Veerkamp, J. S. J., Hoogstraten, J., Prins, P. J. M. Childhood dental fear in the Netherlands: prevalence and normative data. Community Dentistry and Oral Epidemiology. 2002, 30, 101-107.

173. ten Berge, M., Veerkamp, J. S. J., Hoogstraten, J. The etiology of childhood dental fear: the role of dental and conditioning experiences. Journal of Anxiety Disorders. 2002, 16, 321-329.

174. ter Horst, G., Prins, P., Veerkamp, J., Verhey, H. Interactions between dentists and anxious child patients: a behavioral analysis. Community Dentistry and Oral Epidemiology. 1987, 15(5), 249252.

175. Themessl-Huber, M., Freeman, R., Humphris, G., MacGillivray, S., Terzi, N. Empirical evidence of the relationship between parental and child dental fear: a structured rewiew and meta-analysis. International Journal of Paediatric Dentistry. 2010, 20, 83-101.

176. Thomas, A., Chess, S. Temperament and development. Oxford: Brunner/Mazel, 1977; 1-270.

177. Thomson, W., Locker, D., Poulton, R. Incidence of dental anxiety in young adults in relation to dental treatment experience. Community Dentistry and Oral Epidemiology. 2000, 28, 289-294.

178. Thomson, W. M., Broadbent, J. M., Locker, D., Poulton, R. Trajectories of dental anxiety in a birth cohort. Community Dentistry and Oral Epidemiology. 2009, 37(3), 209-219.

179. Toren, P., Sadeh, M., Wolmer, L., Eldar, S., Koren, S., Weizman, R., Laor, N. Neurocognitive correlates of anxiety disorders in children: a preliminary report. Journal of Anxiety Disorders. 2000, 14(3), 239-247.

180. Tuma, C. F. How to help your child to be a good dental patient: an open letter to parents. Journal of Dentistry for Children. 1954, 21, 81-84.

181. US National Institute of Mental Health Fear/Phobia Statistics. http://www.statisticbrain.com/fear-phobia-statistics/, sk. 23.05.2016.

182. Vann, W. F., Lee, J. Y., Baker, D., Divaris, K. Oral health lteracy among female caregivers: impact on oral health outcomes in early childhood. Journal of Dental Research. 2010, 89, 13951400.

183. Van Wijk, A. J., Hoogstraten, J. Experience with dental pain and fear of dental pain. Journal of Dental Research. 2005, 84(10), 947-950.

184. Varpio, M., Wellfelt, B. Some characteristics of children with dental behavior problems. Fiveyear follow-up of pedodontic treatment. Swedish Dental Journal. 1991, 15, 85-93.

185. Vassend, O., Roysamb, E., Nielsen, C. S. Dental anxiety in relation to neuroticism and pain sensivity. A twin study. Journal of Anxiety Disorders. 2011, 25, 302-308.

186. Venham, L., Gaulin-Kremer, E., Munster, E., Bengston-Audia, D., Cohan, J. Interval rating scales for children's dental anxiety and uncooperative behavior. Pediatric Dentistry. 1980, 2, 195-202.

187. Versloot, J., Veerkamp, J. S. J., Hoogstrasten, J., Martens, L. Children's coping with pain during dental care. Community Dentistry and Oral Epidemiology. 2004, 32, 456-461.

188. Vignehsa, H., Chellapah, N. K., Milgrom, P., Going, R., Teo, C. S. A clinical evaluation of highand low-fear children in Singapore. Journal of Dentistry for Children. 1990, 57, 224-229.

189. Vika, M., Agdal, M. L. Intra-oral injection phobia. In: Cognitive behaviour therapy for dental phobia and anxiety. Lars G. Öst, Erik Skaret, eds. Oxford: Wiley-Blackwell, 2013.

190. Vogels, W. E. J. C., Aartman, I. H. A., Veerkamp, J. S. J. Dental fear in children with a cleft lip and/or cleft palate. The Cleft Palate-Craniofacial Journal. 2011, 48(6), 736-740. 
191. Watson, J. B., Rayner R. Conditional emotional reactions. Journal of Experimental Psychology. 1920, 3, 1-14 (http://psychclassics.yorku.ca/Watson/emotion.htm, sk.12.06.2016).

192. Way, D. C. A psychological approach to dentistry for children. Journal of Canadian Dental Association. 1952, 18, 188-197.

193. Weems, C. F., Costa, N. M. Developmentall differences in the expression of childhood anxiety symptoms and fears. Journal of American Academy of Child and Adolescent Psychiatry. 2005, 44(7), 656-663.

194. Weinstein, P., Getz, T., Ratener, P., Domoto, P. The effect of dentists' behaviors on fear-related behaviors in children. Journal of American Dental Association. 1982, 104(1), 32-38.

195. Welly, A., Lang, H., Welly, D., Kropp, P. Impact of social status and time of the first dental visit on children behaviour and dental chart. International Journal of Paediatric Dentistry. 2011, 21(1), 272 [abstract].

196. Winer, G. A. A review and analysis of children's fearful behaviour in dental settings. Child Development. 1982, 53, 1111-1133.

197. Wogelius, P., Poulsen, S., Sorensen, H. T. Asthma, ear problems, and dental anxiety among 6- to 8-yr-olds in Denmark: a population-based cross-sectional study. European Journal of Oral Sciences. 2003, 111, 472-476.

198. Wogelius, P., Rosthoj, S., Dahllof, G., Poulsen, S. Dental anxiety among survivors of childhood cancer: a cross-sectional study. International Journal of Paediatric Dentistry. 2009, 19, 121-126.

199. Wolpe, J., Lang, P. J. A fear survey Schedule for use in behavior therapy. Behavior Research \& Therapy. 1964, 2, 27-30.

200. Wright, G. Z. Psychological management of children's behaviour. In: Dentistry for the child and adolescent. R. D. Mcdonald, D.R. Avery, eds. $6^{\text {th }}$ ed. St Louis: Mosby; 2000.

201. Yeap, C. K., Slack-Smith, L. M. Internet information on child dental health and the first dental visit. Australian Dental Journal. 2013, 58, 276-282.

202. Yuzugullu, B., Gulsahi, A., Celik, C., Bulut, S. Dental anxiety and fear: realtionship with oral health behavior in a Turkish population. International Journal of Prosthodontics. 2014, 27(1), 50-53.

203. Zhou, Y., Cameron, E., Forbes, G., Humphris, G. Systematic review of the effect of dental staff behaviour on child dental patient anxiety and behaviour. Patient Education and Counseling. 2011, 85, 4-13.

204. Zuckerman, M. Sensation seeking: beyound the optimal level of arousal. Lawrence Erlbaum Associates Software \& Alternative Media, Incorporated, 1979.

205. http://www.eapd.eu/804C40C2.en.aspx [skat.20.01.2017.]

206. http://www.folktandvardenstockholm.se/ [skat.20.01.2017.] 


\section{PATEICĪBAS}

Visdziḷākā pateicība manām darba vadītājām profesorei Rūtai Carei un profesorei Malgožatai Raščevskai par milzīgo ieguldījumu un atbalstu darba rakstīšanas laikā. Paldies profesorei R. Carei par ievirzī̌sanu profesijāâ, bērnu zobārstniecībā. Paldies profesorei M.Raščevskai par lielo rūpību un precizitāti darba laikā, kā arī izglītošanu statistikas laukā.

Paldies kolēgiem Zobu terapijas un mutes veselības katedrā un profesorei Andai Brinkmanei par atbalstu darba veikšanas gaitā.

İpašs paldies profesorei Egitai Senakolai un kolēǵiem Zobu higiēnistu akadēmiskajā skolā par lielo atbalstu un perspektīvas došanu.

Paldies profesorei Ilgai Urtānei par iespēju veikt pētījumu un kolēǵiem RSU Stomatologijas institūta Bērnu nodaḷā par palīdzību darba tapšanā. Paldies arī kolēgiem zobārstniecības klīnikā Akrībija.

Paldies profesorei Ingrīdai Čèmai par morālo atbalstu.

Paldies promocijas darba recenzentiem profesorei Ilzei Akotai, docentei Daigai Kviļūnai un docentei Ingai Skreitulei-Pikšei par veltîto laiku.

Paldies maniem vecākiem par izglītību un vēlmi vienmēr mācīties un apgūt ko jaunu. Paldies māsai par morālo un praktisko atbalstu.

İpašs paldies manam vīram Ivo par mīlestību, pacietību un atbalstu visā garajā mācību ceḷā. 
PIELIKUMI 


\section{1. pielikums}

Veidlapa $\mathrm{Nr} \mathrm{E}-9$ (2)

RSU ĒTIKAS KOMITEJAS LẼMUS

Rĩga, Dzirciema iela 16, LV-1007

Tel.67409137

\begin{tabular}{lll}
\hline Komitejas sastāvs & Kvalifikācija & Nodarbošanās \\
\hline 1. Asoc. prof. Olafs Brūvers & Dr.miss. & teologs \\
2. Profesore Vija Sĩle & Dr.phil. & filozofs \\
3. Docente Santa Purvina & Dr.med. & farmakologs \\
4. Profesore Regīna Kleina & Dr.med. & patanatoms \\
5. Asoc. prof. Egils Korṇevs & Dr.habil.med. & stomatologs
\end{tabular}

\section{Pieteikuma iesniedzējs: Līga Kronina}

RSU, Doktorantūras noda|a

Pētījuma nosaukums: Bērnu baiḷu un trauksmes zobārstniecībā līmeña, izplatības un to saistība ar mutes dobuma stāvokli un citiem psihosociāliem faktoriem, novērtēšana 4-12 gadus veciem bērniem.

lesniegšanas datums: 27.10.2010.

Pētījuma protokols:

(X) Pētījuma veids: anketēšana

(X) Pētījuma populācija: 300 bērni un viṇu vecāki, kas datu vākšanas laikā apmeklēs

RSU Stomatologijas institūtu Bērnu noda|u un piekritīs piedalîties pētījumā

(X) Informācija par pētījumu:

(X) Piekrišana dalībai pētījumã:

Citi dokumenti:

1. Anketa par bërna attieksmi pret zobārstu

2. Bërnu Bailu Pārskats (Zobārstniecības apakšskala)

3. Aptauja par vecāku attieksmi pret zobārstu

4. PVO Mutes veselības novērtē̌xanas forma (IC-DAS)

5. Frankla skala - novērtējums bërna uzvedībai pie zobārsta

6. RSU Stomatologijas institute direktores piekrišana

7. RSU Terapeitiskās Stomatoloǵijas katedras vadītājas piekrišana

Lēmums: piekrist biomedicīniskajam pētîjumam

Komitejas priekšsēenētājs Qlafs Brūvers Tituls: Dr.miss., asoc.prof.

Paraksts

Êtikas komitejas sēdes datums: 28.10.2010. 


\section{Informācijas un piekrišanas veidlapas forma.}

Lūdzu Jūs piedalīties pētījumā par bērnu un viṇu vecāku attieksmi pret zobārstu. Aicinu Jūs rūpīgi iepazīties ar turpmāko informāciju par projektu, lai varētu pieṇemt lēmumu par piedalīšanos vai nepiedalîšanos tajā.

Rīgas Stradiṇa Universitātes doktorante, zobārste Līga Kroniṇa veic pētījumu par bērnu un vinu vecāku attieksmi pret zobārstu un tās iespējamiem cēloṇiem (piemēram, iepriekšēju pieredzi, temperamentu, trauksmi) un to saistību ar zobu veselību. Šì pētījuma ietvaros tiks pārbaudīts mutes dobuma stāvoklis 300 bērniem vecumā no 4 līdz 12 gadiem, kā arī aptaujāti šo bērnu vecāki. Jums tiks jautāts par Jūsu un Jūsu bērna attieksmi, izjūtām un pieredzi pie zobārsta un citiem ārstiem, kā arī par dažām Jūsu bērna rakstura iezīmēm un reakciju dažādās dzīves situācijās. Ja Jums trūks informācijas par bērna izjūtām, lūdzu, pārrunājiet šo jautājumu ar bērnu. Tā kā katrā pētījumā svarīga ir informācija par dalībnieku demogrāfiskajiem datiem, proti, vecumu, izglīīību, ǵimenes stāvokli u.c., tad Jums tiks uzdoti arī šādi jautājumi. Pirms katras anketas būs sniegta instrukcija, kā to aizpildìt. Anketu aizpildī̌sana aizṇems apmēram 15 minūtes. Pēc tam bērnam tiks pārbaudīti un reǵistrēti zobi, kā arī sniegta nepieciešamā zobārstniecības palīdzība (jau ārpus pētījuma ietvariem). Visi Jūsu un Jūsu bērna sniegtie dati būs anonīmi, kā arī tiks saglabāti, ievērojot konfidencialitāti. Jūsu sniegtā informācija palīdzēs labāk izprast bērnu izjūtas un uzvedību pie zobārsta un to iemeslus. Tāpat šie dati palīdzēs noteikt, kāda ir izplatītākā pieredze un attieksme pret zobārstiem tieši Latvijā, jo iepriekš mūsu valstī šãds pētījums nav veikts.

Pētījums nav saistīts ne ar kādiem medicīniskiem riskiem. Tomēr, ja Jūs vai Jūsu bērns nevēlaties atbildēt uz kādu no jautājumiem vai piedalīties šajā pētījumā vispār, Jūs varat atteikties no dalības tajā. Jūsu atteikums nekādā veidā neietekmēs iespējas bērnam saṇemt tos veselības aprūpes pakalpojumus, kas tiek vai tiktu sanemti parasti.

\section{Vienošanās par piekrišanu.}

Šĩ pētījuma būtība man ir pilnībā paskaidrota. Man tika sniegta iespēja uzdot jautājumus par katru no izpētes aspektiem. Es apzinos, ka mana un mana bērna piedalī̌anās pētījumā ir brīvprātīga un es varu savu piekrišanu atsaukt jebkurā laikā. Es saprotu, ka gadījumā, ja nevēlos piedalīties pētījumā, tas nekādā veidā neietekmēs iespējas bērnam saṇemt tos veselības aprūpes pakalpojumus, ko mans bērns parasti saṇem. Mani un mana bērna sniegtie dati ir anonīmi, un turpmāk tiks uzglabāti un apstrādāti, ievērojot konfidencialitāti.

Es, apakšā parakstījies/-usies, ar šo dodu piekrišanu savai un mana bērna līdzdalībai augstāk minētajā pētijjumā. Es esmu saṇēmis/-usi glabāšanā šīs piekrišanas kopiju. Man ir zināms, ka, ja man radīsies kādi jautājumi par šo pētījumu, varu griezties pie dr. Līgas Kroniṇas vai prof. Rūtas Cares, piezvanot pa tel. 29169225. Ja man rastos kādi jautājumi attiecībā uz mana bērna tiesībām, es varu vērsties RSU Ëtikas komisijā.

Ja pēc aț̣aujas veidlapas izlasīšanas Jums vairāk nav jautājumu par piekrišanu, lūdzu parakstieties, kā arī uzrakstiet datumu norādītajā vietā.

Paraksts Datums 


\section{Aptauja par vecāku attieksmi pret zobārstu.}

Lūdzu Jūs atbildēt uz dažiem jautājumiem par Jūsu attieksmi pret zobārstiem un izjūtām saistībā ar zobu ārstēšanu. Lūdzu, izlasiet katru apgalvojumu un atzīmējiet to atbildi, kas visatbilstošāk raksturo Jūsu izjūtas pie zobārsta!

1. Kā Jūs justos, ja Jums nākošajā dienā būtu jāiet pie zobārsta?
o brīvi
o nedaudz nemierīgi
o saspringtāk nekā parasti
o loti satraukti
o nosvīstu vai justu fizisku nelabumu

2. Kā Jūs jūtaties, kad Jūs gaidāt savu kārtu pie zobārsta uzgaidāmajā telpā?
o brīvi
o nedaudz nemierīgi
o saspringtāk nekā parasti
o loti satraukti
o nosvīstu vai justu fizisku nelabumu

3. Kā Jūs jūtaties, sēžot krēslā un gaidot, kamēr zobārsts sagatavos injekciju?
o brīvi
o nedaudz nemierīgi
o saspringtāk nekā parasti
o loti satraukti
o nosvīstu vai justu fizisku nelabumu

4. Kā Jūs jūtaties, sēžot zobārsta krēslā un gaidot, kad zobārsts sāks urbt?
o brīvi
o nedaudz nemierīgi
o saspringtāk nekā parasti
o loti satraukti
o nosvīstu vai justu fizisku nelabumu

5. Kā Jūs jūtaties, kad zobu higiēnists izṇem instrumentus, lai notīrītu zobus ap smaganām?
o brīvi
o nedaudz nemierīgi
o saspringtāk nekā parasti
o loti satraukti
o nosvīstu vai justu fizisku nelabumu 
Aizpildī̌sanas datums

Bērna dzimš.datums

Šifrs

\section{Bērnu Baiḷu Pārskats (Zobārstniecības apakšskala)}

Šīs aptaujas mērķis ir noskaidrot Jūsu bērna izjūtas zobārstniecības situācijās. Turpmāk minēti tipiskākie baiļu iemesli. Lūdzu, izlasiet jautājumus un novērtējiet 5 ballu skalā, cik lielā mērā Jūsu bērnam ir bail katrā no tām. Lūdzu, ielieciet krustiṇu tajā kolonnā, kas vislabāk raksturo Jūsu bērna baiļu pakāpi. Ja Jums trūkst informācijas par bērna izjūtām, lūdzu, pārrunājiet šo jautājumu ar bērnu.

\section{Jautājumi}

1. No zobārstiem

\section{No ārstiem}

3. No injekcijām (špricēm)

4. Kad pārbauda viṇa/viṇas muti

5. Kad viṇam/viṇai jāatver mute

6. Kad nepazīstams cilvēks pieskaras viṇam/vin̦ai

7. Kad kāds pētoši skatās uz viṇu (novēro)

\section{Kad zobārsts urbj}

9. No skata, kad zobārsts urbj

10. No zobu urbšanas trokšṇa,skaṇas

11. Kad viņam/viṇai liek mutē instrumentus

12. No smakšanas vai aizrīšanās

13. Kad jāiet slimnīcā

14. No cilvēkiem baltos halātos

15. Kad zobārsts vai higiēnists tīra viņa/viṇas zobus
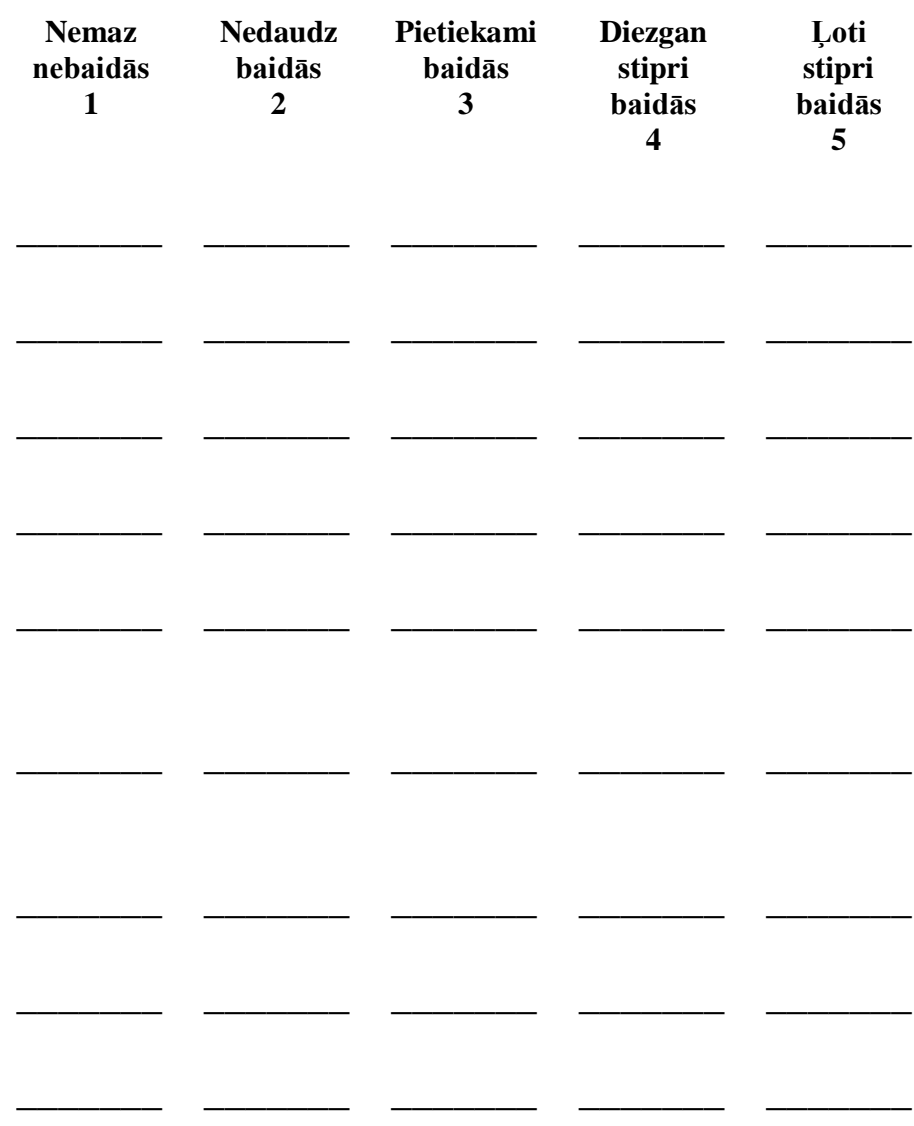

\section{(1)}
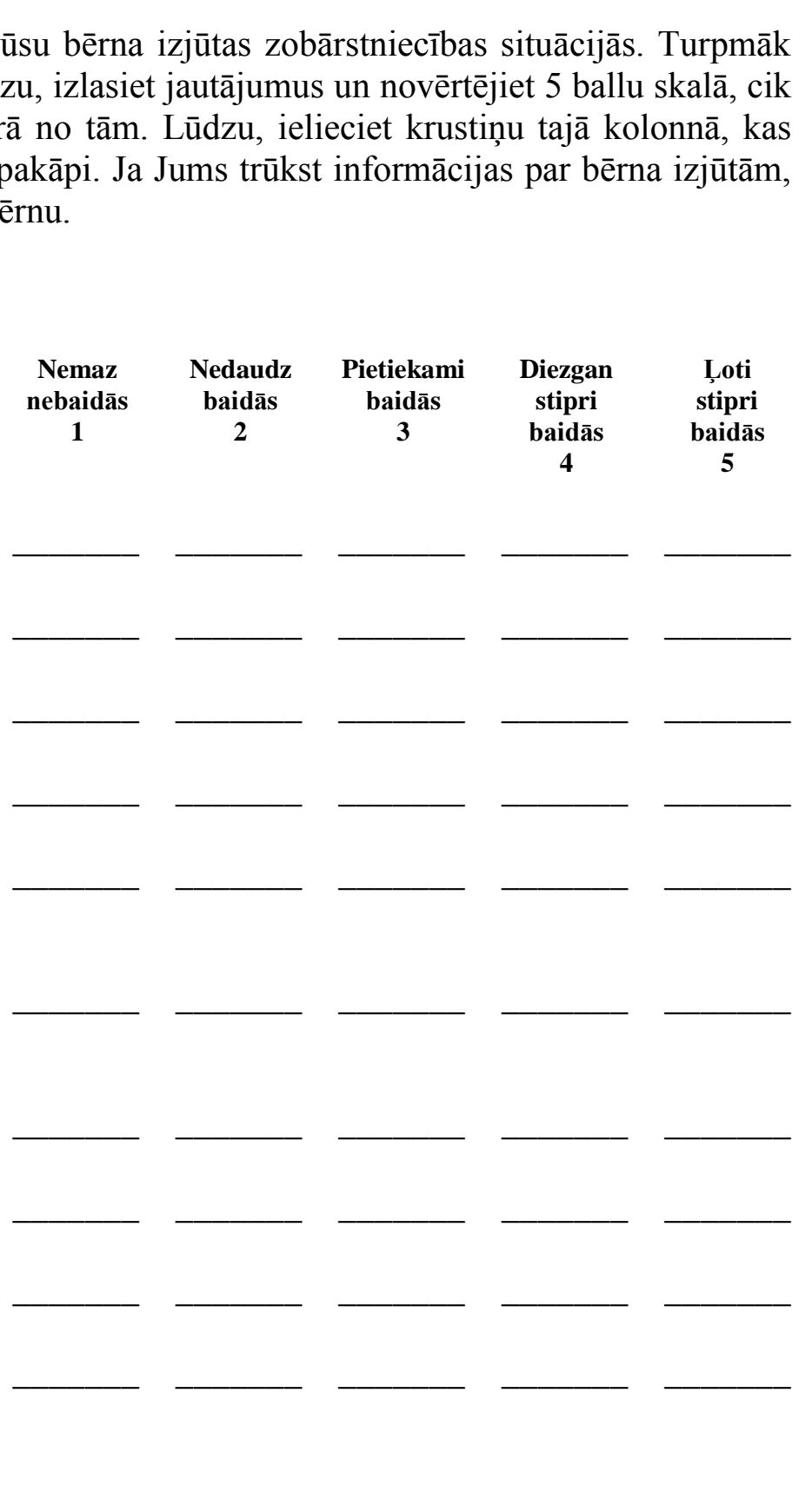

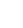




\section{Anketa par bērna attieksmi pret zobārstu.}

Aizpildīšanas datums

Bērna dzimš.datums

Šifrs

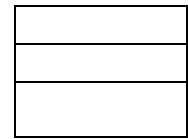

Cienījamie vecāki! Turpmāk Jums tiks lūgta vispārēja informācija par Jūsu ğimeni, kā arī sīkāki dati par Jūsu bērna līdzšinējo pieredzi ar ārstiem un zobārstiem, attieksmi pret zobu veselību, uzvedību dažādās situācijās un stresu gimenē pēdējā gada laikā. Jūsu atbildes palīdzēs labāk izprast bērna izjūtas un uzvedību, apmeklējot zobārstu. Lūdzu, rūpīgi izlasiet jautājumus, izvēlieties Jūsu bērnu vislabāk raksturojošāko atbildi un atzīmējiet to ar krustin̦u (x). Atsevišksos jautājumos, kur norādīts, var atz̄̄mēt vairākas atbildes.

\section{Vispārīgā informācija par bērnu un vinga gimeni}

1. Bērna dzimums (atzīmēiet ar X atbilstošo variantu):: $\square$ meitene $\square$ zēns

2. Dzimšanas dati /datums, mēnesis, gads/

3. Kas dzīvo kopā ar bērnu gimenē:? (atzīmëjiet ar Xatbilstošo variantu):
a) $\square$ māte, b)
b) $\square$ tēvs, c)
c) $\square$ vecmāmiņa, d)
d) $\square$ vectēvs,
e) $\square$ brālis, cik f) $\square$ māsa, cik
g) $\square$ audžumāte,
h) $\square$ audžutēvs
i) $\square$ aizbildnis

4. Vai bērns ir adoptēts vai atrodas aizbildniecībā? (atzīmēiet ar Xatbilstošo variantu): $\square$ jā $\square$ nē

5. Jā uz 4. jautājumu atbildējāt ar ,jā̄", tad cik ilgi bērns ir audžu ğimenēe? /gados/

6. Vecāku pašreizējais ğimenes stāvoklis, t.i. viņi dz̄ivo (atzīmējiet ar X atbilstošo variantu):
a. $\square$ precējušies, dzīvo kopā
b. $\square$ neprecējušies, dzīvo kopā
c. $\square$ precējušies, dzīvo šķirti
d. $\square$ neprecējušies, dzīvo šķirti
e. $\square$ škīirušies
f. $\square$ atraitne/-is

\section{Informācija par māti (audžumāti, aizbildni)}

7.1. Mātes (audžumātes, aizbildnes) vecums /gados/

8.1. Mātes (audžumātes, aizbildnes) izglītība:
a) $\square$ pamatizglīīìba
b) $\square$ pamatizglītība + arodskola
c) $\square$ vidèjā izglìtîba
d) $\square$ vidējā izglīīiba + arodskola
e) $\square$ nepabeigta augstākā izglìtîba (vismaz 1 gads)
f) $\square$ augstākā izglīīîba
g) $\square$ cits variants

9.1. Mātes (audžumātes, aizbildnes) nodarbošanās:

a) apgūtais arods, specialitāte

b)pašreizējā nodarbošanās
Informācija par tēvu (audžutēvu, aizbildni)

7.2. Tèva (audžutēva, aizbildņa) vecums /gados/

8.2. Tèva (audžutēva, aizbildņa) izglītība:
a) $\square$ pamatizglītība
b) $\square$ pamatizglīitiba + arodskola
c) $\square$ vidējā izglìtîba
d) $\square$ vidējā izglìtība + arodskola
e) $\square$ nepabeigta augstākā izglîtîba (vismaz 1 gads)
f) $\square$ augstākā izglītība
g) $\square$ cits variants

9.2. Tēva (audžumātes, aizbildnes) nodarbošanās:
a) apgūtais arods, specialitāte
b)pašreizējā nodarbošanās

10. Kopējais gimenes ienākumu līmenis:
a) $\square 50$ Ls un mazāk latu uz 1 cilvēku gimenē
b) $\square$ no 51- 100 Ls uz 1 cilvēku ğimenē
c) $\square$ no 101-200 Ls uz 1 cilvēku gimenē
d) $\square$ no 201- 400 Ls uz 1 cilvēku gímenē
e) $\square$ virs 401 Ls uz 1 cilvēku ǵimenē

II. Bērna pieredze attiecībās ar ārstiem, medicīnisko personālu (bet ne zobārstiem)

1. Vai bērnam ir kādas hroniskas, pastāvīgas slimības, kas kaut kādā mērā ietekmē (ierobežo) viṇa dzīvesveidu ?
a) $\square$ jā
(lūdzu norādiet, kādas)
b) $\square$ nē 
2. Cik bieži bērns slimo?
a) $\square$ ne biežāk kā 1 reizi gadā
b) $\square$ 2-3 reizes gadā
c) $\square 4$ un vairāk reizes gadā

3. Cik bieži bērns apmeklē ārstus, iznemot zobārstu?
a) $\square$ ne biežāk kā 1 reizi gadā
b) $\square$ 2-3 reizes gadā
c) $\square 4$ un vairāk reizes gadā

4. Kāda attieksme bērnam ir pret ārstiem un citu medicīnisku personālu?
a) $\square$ draudzīga
b) $\square$ neitrāla
c) $\square$ piesardzīga
d) $\square$ bailīga
e) $\square$ citāda

5. Vai bērns ir bijis vizītēs pie ārstiem, izṇemot zobārstu ?

(lūdzu norādiet, kāda)
a. $\square$ nemaz nav bijis
b. $\square$ retāk kā reizi gadā
c. $\square$ vismaz 1 reizi gadā
d. $\square$ 2-3 reizes gadā
e. $\square$ 4-5 reizes gadā
f. $\square$ virs 6 reizēm gadā

6. Vai bērnam ir bijusi kāda traumatiska pieredze ar ārstiem, izṇemot zobārstu?
a) $\square$ jā
(lū $\overline{d z u}$ norādiet, cik reizes un kādà vecumāa)
b) $\square$ nē

7. Vai bērns ir ārstējies slimnīcā?
a) $\square \mathrm{jā}$
(lūdzu norādiet, cik reizes un kādā vecumā)
b) $\square$ nē

8. Vai bērns ir ārstēts vispārējā narkozēê?
a) $\square$ jā
(lüdzu norādiet, cik reizes un kādà vecumā)
b) $\square$ nē

9. Vai bērnam bijušas kādas traumas, kuru dēḷ bija nepieciešama neatliekamā palīdz̄̄ba?
a) $\square$ jā
b) $\square$ nē

(lūdzu norādiet, cik reizes un kādā vecumāa)

\section{Bērna pieredze pie zobārstiem.}

1. Kādā vecumā bērns pirmo reizi tika aizvests pie zobārsta?

Lūdzu, ja iespējams, norādiet bērna vecumu gados un mēnešos gadi mēneši

2. Kādā vecumā, Jūsuprāt, būtu jābūt bērna pirmajai vizītei pie zobārsta?

3. Pirmo reizi pie zobārsta devāties:
a. $\square$ lai iepazītu zobārsta kabinetu, pārbaudītu zobus
b. $\square$ nosūtīja kāds cits ārsts
c. $\square$ ievērojāt kādas izmainas bērna zobos
d. $\square$ zobu sāpju dēl
e. $\square$ cits iemesls

4. Cik regulāri vediet bērnu pie zobārstu, lai pārbaudītu zobu stāvokli?
a.
$\square$ ik pēc pusgada ( jeb 2 reizes gadā)
b.
apmēram 1 reizi gadā
c. $\quad \square$ retāk kā 1 reizi gadā
d. $\square$ gandrīz neesam apmeklējuši

5. Kad Jūs parasti vediet bērnu pie zobārsta?
a.
$\square$ katru gadu noteiktos laikos
b.
kad atceros
c. $\quad \square$ kad ievēroju kādas izmaiņas zobos
d. $\square$ kad nedaudz sāp vai traucē
e. $\quad \square$ kad ir ilgstošas zobu sāpes, kas nepāriet
f. $\square$ neejam vispār 
6. Kā sagatavojiet bērnu zobārsta apmeklējumam?

a. $\square$ apskatot un lasot priekšā bērnu grāmatas par šo tēmu, pārrunājat redzēto un lasīto

b. $\square$ mierinot, ka zobārsts tikai apskatīs zobus, neko nedarīs un nekas nesāpēs

c. $\square$ stāstot par savu pieredzi pie zobārsta

d. $\square$ ñemot bērnu līdz, ejot pie sava zobārsta

e. $\square$ apsolot balvu par labu uzvešanos pie zobārsta

f. $\square$ nekā īpaši nesagatavojat

g. $\square$ cita atbilde

7. Kādu ārstēšanu pie zobārsta bērns saṇēmis līdz šim? Lūdzu, atzīmējiet visus pieredzētos ārstēšanas veidus un pēc iespējas precīzāk norādiet, kādā vecumā tā tika veikta 1.reizi?

a. $\square$ pārbaudi un/vai konsultāciju

b. $\quad \square$ zobu higiēnu

c. $\square$ plombēšanu bez narkozes

d. $\square$ plombēšanu vietējā narkozē

e. $\quad \square$ plombēšanu vispārējā narkozē

f. $\square$ zoba ekstrakciju (izraušanu) vietējā narkozē

g. $\square$ zoba ekstrakciju (izraušanu) vispārējā narkozē

h. $\quad \square$ ekstrakciju (izraušanu) bez narkozes

i. $\quad \square$ citu ārstēšanu

8. Līdz šim veiktās zobārsta ārstēšanas procedūras noritēja:

a. $\quad \square$ vienmēr bez grūtībām, bērns viegli tās pien̦ēma

b. $\quad \square$ pārsvarā bez grūtībām

c. $\quad \square$ pārsvarā ar nelielām grūtībām

d. $\square$ gandrīz vienmēr ar grūtībām

e. $\quad \square$ vienmēer ar lielām grūtībām

9. Kādas emocijas bērnam parādās, ejot pie zobārsta?

a. $\square$ prieks, interese

b. $\quad \square$ neitrāla, vienaldzīga attieksme

c. $\square$ satraukums, bažas

d. $\square$ bailes, raudāšana

e. $\quad \square$ aktīvs protests un pretestība

f. $\quad \square$ panika vai histērija

10. Vai bērnam ir bijusi negatīva, traumatiska pieredze pie zobārsta (piemēram, sāpes, neiejūtīga attieksme)?
a) $\square$ jā, kāda
b) $\square$ nē

11. Ja bērnam bija negatīva pieredze pie zobārsta, ko darījāt tālāk?
a. $\quad \square$ gājāt tikai pie higiēnista
b. $\quad \square$ gājāt vēlreiz pie tā paša zobārsta
c. $\quad \square$ gājāt pie cita zobārsta/ uz citu klīniku
d. $\square$ ārstējāt zobus vispārējā narkozē
e. $\square$ negājāt nekur, nogaidījāt

12. Vai Jums ir gadījies pārrunāt savu person̄̄go negatīvo pieredzi pie zobārsta (piemēram, sāpes, agrākās ārstēšanas metodes, neiejūtīga attieksme) bērna klātbūtnēe
a) $\square$ jā
b) $\square$ nē

13. Vai Jums ir gadījies baidīt bērnu ar zobārstu (kā soda metodi)?
a. $\square$ nē, nekad
b. $\quad \square$ jā, vienreiz
c. $\square \mathrm{jā}$, dažas reizes
d. $\square$ jā, vairākas reizes 
14. Vai esiet atlikuši jau sarunātu bērna vizīti pie zobārsta kāda nebūtiska iemesla dēḷ, piemēram, nolēmāt doties citur vai darīt ko citu?
a. $\square$ nē, nekad
b. $\quad \square \mathrm{jā}$, vienreiz
c. $\quad \square$ jā, dažas reizes
d. $\square$ jā, vairākas reizes

15. Kas parasti pavada bērnu pie zobārsta?
a. $\square$ tikai māte
b. $\square$ tikai tēvs
c. $\quad \square$ kuram ir laiks
d. $\quad \square$ kurš pats nebaidās no zobārsta
e. $\quad \square$ kuru klausa bērns
f. $\square$ jebkurš no gimenes pieaugušajiem locekḷiem

16. Kurā dienas laikā parasti vedat bērnu pie zobārsta?
a. $\square$ parasti dienas pirmajā pusē
b. $\quad \square$ parasti pēcpusdienā, pēc bērnudārza/skolas
c. $\square$ parasti vakarā, pēc darba
d. $\square$ dažādos laikos

\section{Bērna attieksme pret zobu veselību}

1. Cik regulāri Jūsu bērns tīra zobus?
a. $\square$ katru dienu vismaz 2 reizes
b. $\square$ katru dienu vismaz 1 reizi
c. $\square$ neregulāri, bet vairākas reizes nedēḷā
d. $\square$ neregulāri, bet vairākas reizes mēnesī

2. Vai pārbaudiet bērna zobus pēc tīrǐšanas? a) $\square$ jā b) $\square$ nē

3. Kā Jūsu bērns uztver ikdienišķo zobu tīrīšanu?
a. $\square$ kā pašsaprotamu, ar izpratni, ka to vajag zobu veselības dēl
b. $\square$ kā pienākumu
c. $\square$ izvairās no tīrī̌sanas
d. $\square$ atsakās to veikt, bet izdara to pieaugušā uzraudzībā
e. $\square$ atsakās to veikt un nedara to pat pieaugušā uzraudzībā

4. Vai Jūsu bērns lieto fluora tabletes?
a. $\square$ jā, regulāri
b. $\square$ jā, neregulāri
c. $\square$ agrāk lietoja, patlaban vairs nē
d. $\square$ nelieto un nekad nav lietojis

5. Kur saṇemiet informāciju par bērna zobu kopšanu?
a. $\square$ no bērnu ārsta/ğimenes ārsta
b. $\square$ no zobārsta
c. $\square$ no zobu higiēnistiem
d. $\square$ no plašsaziņas līdzekḷiem (laikrakstiem, žurnāliem, TV, radio, interneta portāliem utt.)
e. $\square$ no draugiem un paziņām
f. $\square$ nekur nesañemat
g. $\square$ cita atbilde

6. Kur saṇemat informāciju par bērna sagatavošanu vizītei pie zobārsta?
a. $\square$ no bērnu ārsta/gimenes ārsta
b. $\square$ no zobārsta
c. $\square$ no zobu higiēnistiem
d. $\square$ no plašsaziņas līdzekḷiem (laikrakstiem, žurnāliem, TV, radio, interneta portāliem utt.)
e. $\square$ no draugiem un paziṇām
f. $\square$ nekur nesanemat
g. $\square$ cita atbilde 


\section{Bērna uzvedības raksturojums}

1. Lūdzu, novērtējiet 10 ballu sistēmā, cik lielā mērā Jūsu bērnam ir izteiktas šādas īpašības (vērtējuma polos ir ìpašîbu galējas izpausmes):

a. sabiedriskums

$\begin{array}{llllllllllll}\text { Dod priekšroku } & 1 & 2 & 3 & 4 & 5 & 6 & 7 & 8 & 9 & 10 & \text { L.oti labprāt }\end{array}$ vienatnei

b. aktivitāte

$\begin{array}{llllllllllll}\text { Nav aktīvs, } & 1 & 2 & 3 & 4 & 5 & 6 & 7 & 8 & 9 & 10 & \text { Aktīvi darbojas vis }\end{array}$ àtri nogurst

c. impulsivitāte

$\begin{array}{llllllllllll}\text { Var ilgstoši darīt } & 1 & 2 & 3 & 4 & 5 & 6 & 7 & 8 & 9 & 10 & \text { Nepārtraukti }\end{array}$

kaut ko vienu $\quad \square \quad \square \quad \square \quad \square \quad \square \quad \square \quad \square \quad \square \quad \square \quad \square \quad$ pārslēdzas uz

jaunām darbībām

d. emocionāla labilitāte

$\begin{array}{llllllllllll}\text { Noskaņojums ir } & 1 & 2 & 3 & 4 & 5 & 6 & 7 & 8 & 9 & 10 & \text { Âtri mainās }\end{array}$ noturīgs, stabils $\quad \square \quad \square \quad \square \quad \square \quad \square \quad \square \quad \square \quad \square \quad \square \quad \square \quad$ noskaņojums,

e. emocionalitāte

$\begin{array}{llllllllllll}\text { Nepauž } & 1 & 2 & 3 & 4 & 5 & 6 & 7 & 8 & 9 & 10 & \text { Emocijas ir loti spilgtas, } \\ \text { emocijas } & \square & \square & \square & \square & \square & \square & \square & \square & \square & \square & \text { acīmredzamas }\end{array}$

f. kautrīgums

$\begin{array}{llllllllllll}\text { Lēni iejūtas } & 1 & 2 & 3 & 4 & 5 & 6 & 7 & 8 & 9 & 10 & \text { Ātri iejūtas jaunās }\end{array}$ jaunās attiecībās $\square \quad \square \quad \square \quad \square \quad \square \quad \square \quad \square \quad$ attiecībās ar cilvēkiem

2. Vai Jūsu bērns parasti ir viegli satraucams?
a. $\square$ pārsvarā jā
b. $\square$ main̄̄gi, atkarībā no situācijas
c. $\square$ pārsvarā nē
d. $\square$ nav īpaši satraucams

3. Vai bērns spēj pats tikt galā ar savu satraukumu / stresu, nomierināties?
a. $\square$ pārsvarā jā
b. $\square$ main̄igi, atkarībā no situācijas
c. $\square$ pārsvarā nē
d. $\square$ nemaz nevar tikt galā

4. Cik ilgi bērns pārdzīvo kādu satraucošu notikumu vai pieredzi?
a. $\square$ vairākas minūtes
b. $\square$ dažas stundas
c. $\square$ vienu dienu
d. $\square$ vairākas dienas

5. Kas, pēc Jūsu domām, ir bijusi visnepatīkamākā, satraucošākā pieredze bērna mūžā? Kādā vecumā tas notika?

6. Kā Jūs parasti nomierināt bērnu, kad viṇš/a ir satraucies vai nobijies?
a. $\square$ samīlojat
b. $\square$ pārrunājat sīkāk
c. $\square$ pievēršat bērna uzmanību kaut kam citam
d. $\square$ sakāt, lai neuztraucas
e. $\square$ neko īpašu nedarāt
f. $\square$ cita atbilde 
7. Kā Jūs parasti mieriniet bērnu, kad redziet, ka viṇš/a ir bēdīgs/a?

a. $\square$ samīlojat

b. $\square$ pārrunājat sīkāk

c. $\square$ pievēršat bērna uzmanību kaut kam citam

d. $\square$ sakāt, lai neuztraucas

e. $\square$ neko îpašu nedarāt

f. $\square$ cita atbilde

8. Kā Jūs parasti gatavojaties kādam gaidāmam atbildīgam vai satraucošam notikumam?
a. $\square$ pārrunājat sīkāk gaidāmo notikumu
b. $\quad \square$ iedrošināt un uzslavējat bērnu
c. $\square$ sakāt, lai neuztraucas
d. $\square$ neko īpašu nedarāt
e. $\square$ cita atbilde

9. Vai Jūsu bērns baidās no (var atzīmèt vairākas atbildes):
a. $\square$ augstuma
b. $\square$ slēgtām telpām
c. $\square$ palikšanas vienam
d. $\square$ zirnekḷiem/kukainiem
e. $\square$ nepazīstamiem dzīvniekiem
f. $\square$ tumsas
g. $\square$ no svešiem cilvēkiem
h. $\square$ no kā cita

\section{Stress un tā pārvarēšana}

1. Vai pēdējā gada laikā jūsu ğimene ir piedz̄ivojusi kādu no turpmāk minētajiem notikumiem (var atzīmēt vairākas atbildes):
a. $\quad \square$ dzīvesbiedra vai cita ǵimenes locekḷa nāve
b. $\square$ šķiršanās, ğimenes izjukšana
c. $\square$ ǵimenes locekḷa veselības pasliktināšanās
d. $\square$ jauna cilvēka ienākšana ğimenē
e. $\quad \square$ bērnu vai citu ǵimenes locekḷ pārcelšanās uz citu dzīves vietu
f. $\square$ nopietni strīdi ğimenē

2. Vai pēdējā gada laikā Jūs personiski piedzīvojāt kādus turpmāk minētus notikumus (var atzīmēet vairākas atbildes):
a. $\square$ nopietna slimība
b. $\quad \square$ jūtamas dzīves apstākḷu izmainas
c. $\square$ nepatikšanas ar varas iestādēm
d. $\square$ tuva drauga nāve/attiecību izjukšana
e. $\square$ dzīvesvietas maina
f. $\square$ miega traucējumi/bezmiegs
g. $\square$ atvalinājums

3. Vai pēdējā gada laikā darbā Jūs piedzīvojāt kādus turpmāk minētus notikumus (var atzīmēet vairākas atbildes):
a. $\square$ aiziešana pensijā
b. $\square$ atlaišana no darba
c. $\square$ darbavietas maiņa
d. $\square$ pārmaiṇas karjerā (paaugstinājums)
e. $\square$ konflikts ar priekšniecību
f. $\square$ pārmaiņas darba mikroklimatā/apstākḷıs

Paldies par sadarbību! 


\section{AIZPILDA ZOBĀRSTS!}

\section{PVO MUTES VESELĪBAS NOVĒRTĒŠANAS FORMA (ICDAS)}

Vecums (gados)

Dzimte $(\mathrm{V}=1, \mathrm{~S}=2)$

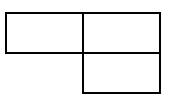

Aizpildīšanas datums

Bērna dzimš.datums

Šifrs

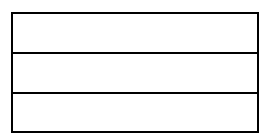

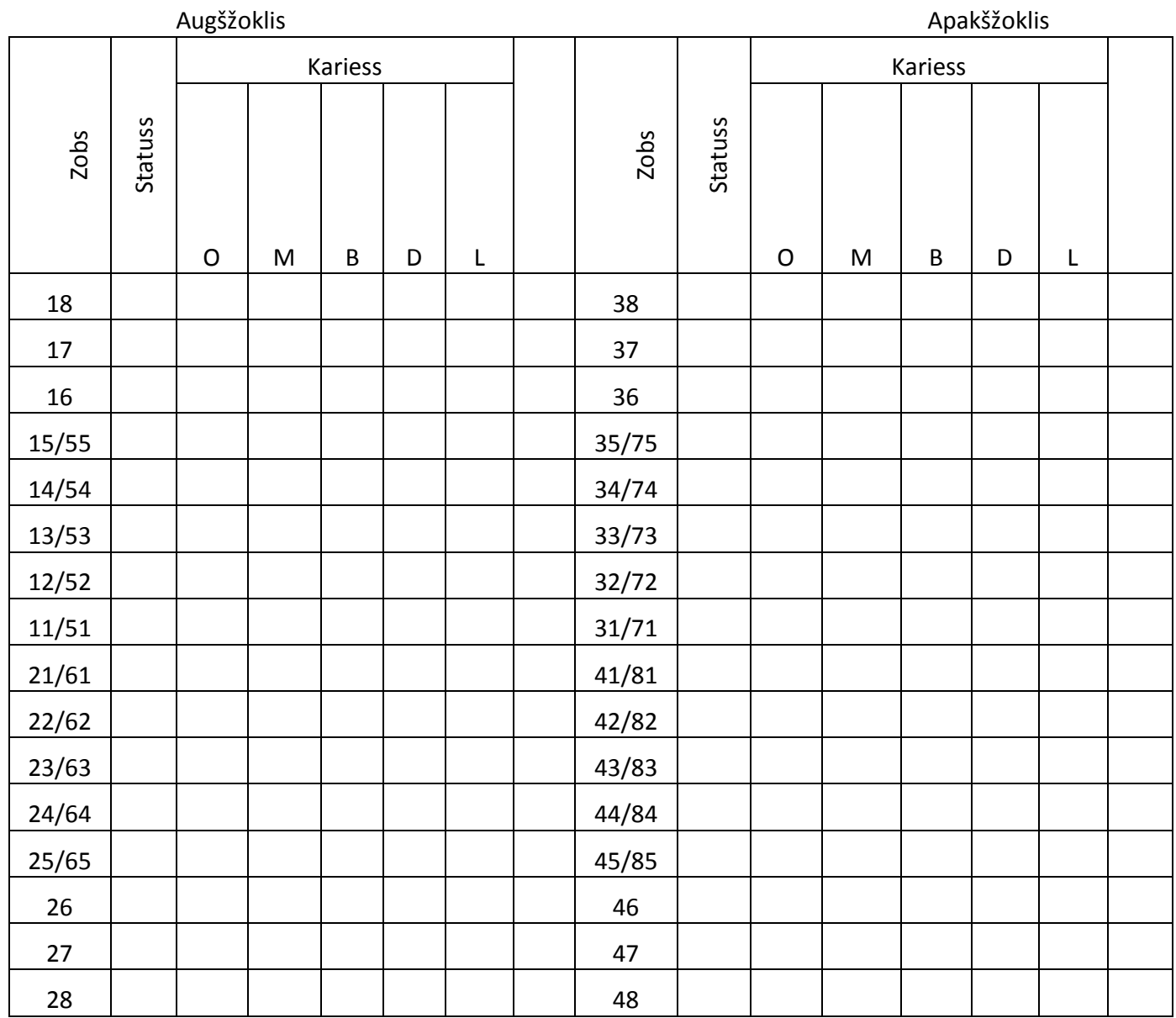

Stāvoklis:

$A=$ intakts piena zobs

$B=$ kariozs piena zobs

$C=$ plombēts piena zobs

$\mathrm{D}=$ neizšḳīlies pastāvīgais zobs

$E=$ ekstrahēts pastāvīgais zobs

$\mathrm{P}=$ izškīilies pastāvīgais zobs
Kariess:

$0=$ intakts

2 = emaljas kariess

$3=$ dentīna kariess

$4=$ kariess ar pulpas iesaistī̌sanos

5 = plombēts ar primāru kariesu

6 = plombēts ar sekundāru kariesu

7 = plombēts

$8=$ izslēgtas virsmas

$9=$ silants vai laka 


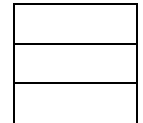

\section{AIZPILDA ZOBĀRSTS!}

\section{Frankla skala - novērtējums bērna uzvedībai pie zobārsta :}

Lūdzu, atzīmējiet ar krustiṇu tajā lodziṇā, kas visprecīzāk raksturo bērna uzvedību pie zobārsta.

\begin{tabular}{|l|l|}
\hline 1. $\begin{array}{l}\text { Izteikti negatīva (bērns atsakās no } \\
\text { ārstēšanas un jebkāda sadarbošanās } \\
\text { ar zobārstu, stipri kliedz, raud vai } \\
\text { citādi protestē, nav iespējams } \\
\text { nodibināt kontaktu ar bērnu) }\end{array}$ & \\
\hline $\begin{array}{l}\text { Drīzāk negatīva ( ar grūtībām } \\
\text { nodibina kontaktu un sadarbojas ar } \\
\text { zobārstu un negribīgi, nelabprāt } \\
\text { atlauj zobu ārstēšanu) }\end{array}$ & \\
\hline $\begin{array}{l}\text { Drīzāk pozitīva (piekrīt ārstēšanai, } \\
\text { brīžiem piesardzīgs, atturīgs vai } \\
\text { noraizējies, bet kopumā sadarbojas } \\
\text { ar zobārstu un seko norādījumiem) }\end{array}$ & \\
\hline $\begin{array}{l}\text { àrstēšanas procesu, smaida un } \\
\text { labprāt lauj ārstēt zobus) }\end{array}$ & \\
\hline \\
zobārstu, interesējas par zobu \\
\hline
\end{tabular}


Aizpildīšanas datums Bērna dzimš.datums

\section{Опросник об отношении родителей к стоматологу.}

Прошу Вас ответить на несколько вопросов об отношении к стоматологу и об ощущениях, связанных с лечением зубов. Пожалуйста, прочтите каждое утверждение и отметьте крестиком тот ответ, который лучше всего характеризует Ваши ощущения у стоматолога.

1. Как Вы себя чувствуете, если в следующий день Вам надо идти к стоматологу?

$\square$ свободно

$\square$ немного неспокойно

$\square$ настороженно

$\square$ сильно волновался (-лась)

$\square$ попотел (-а) или чувствовал (-a) тошноту

2. Как Вы себя чувствуете, когда Вы ждите свою очередь в прихожей?

$\square$ свободно

$\square$ немного неспокойно

$\square$ настороженно

$\square$ сильно волновался (-лась)

$\square$ попотел (-а) или чувствовал (-а) тошноту

3. Как Вы себя чувствуете, сидя в кресле и ожидая, пока стоматолог приготовит инъекцию?

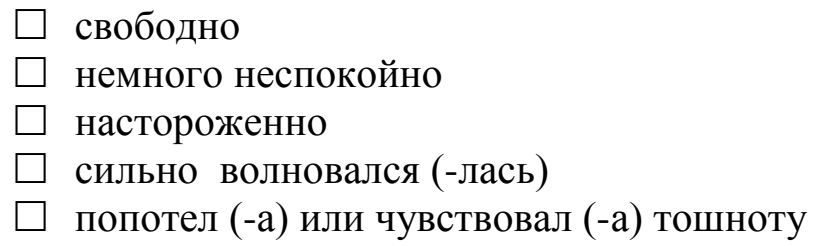

4. Как Вы себя чувствуете, сидя в кресле и ожидая, когда стоматолог начнёт сверлить?

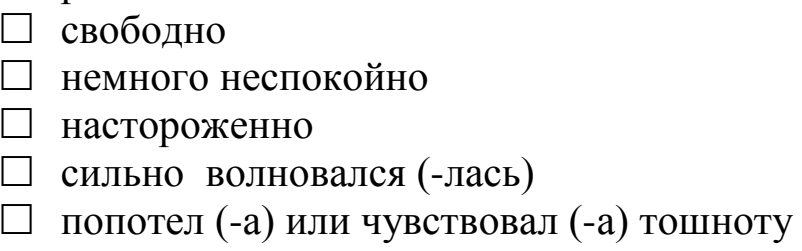

5. Как Вы себя чувствуете, когда зубной гигиенист берёт инструменты, чтобы почистить зубы около дёсен?

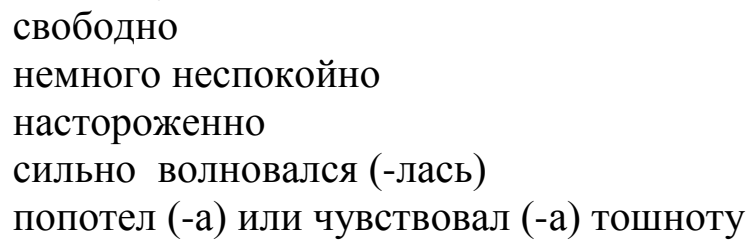


Aizpildīšanas datums

Bērna dzimš.datums

Šifrs

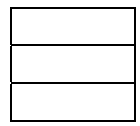

\section{Перечень детских страхов (зубоврачебная шкала )}

Цель этого опроса выяснить ощущения Вашего ребёнка у зубных врачей. Далее упомянуты самые типичные возбудители (причины) страхов. Пожалуйста, прочтите вопросы и оцените в 5-балловой шкале, в какой мере Ваш ребёнок боится каждого из них! Пожалуйста, поставьте крестик в той колонне, которая лучше всего характизирует степень страха Вашего ребёнка каждого из упомянутых причин. Если Вам не хватает информации об ощущениях ребёнка, переговорите этот вопрос с ним/ней.

\section{Вопросы}

1. Зубных врачей

\section{2. Врачей}

\section{3. Инъекций (уколов)}

4. Когда кто-то проверяет его/её рот

5. Когда он/она должен /-на открыть рот

\section{6. Когда незнакомый человек к} нему/ней прикасается

7. Когда кто-то наблюдает за ним/неё

8. Когда зубной врач сверлит

9. Когда он/она видит, как зубной врач сверлит

10. Когда он/она слышит, как зубной врач сверлит

\section{1. Когда врач вводит в полость его/ее рта инструменты}

12. Того, что он задохнется или подавится

\section{3. Когда надо идти в больницу}

14. Людей в белых халатах

15. Когда врач или гигиенист чистит ему/ей зубы

$\begin{array}{ccccc}\begin{array}{c}\text { Совсем не } \\ \text { боится }\end{array} & \begin{array}{c}\text { Немного } \\ \text { боится }\end{array} & \begin{array}{c}\text { Основательно } \\ \text { боится }\end{array} & \begin{array}{c}\text { Довольно } \\ \text { сильно }\end{array} & \begin{array}{c}\text { Очень } \\ \text { боится }\end{array} \\ 1 & 2 & 3 & \text { боится } & 5 \\ & & & & 4\end{array}$
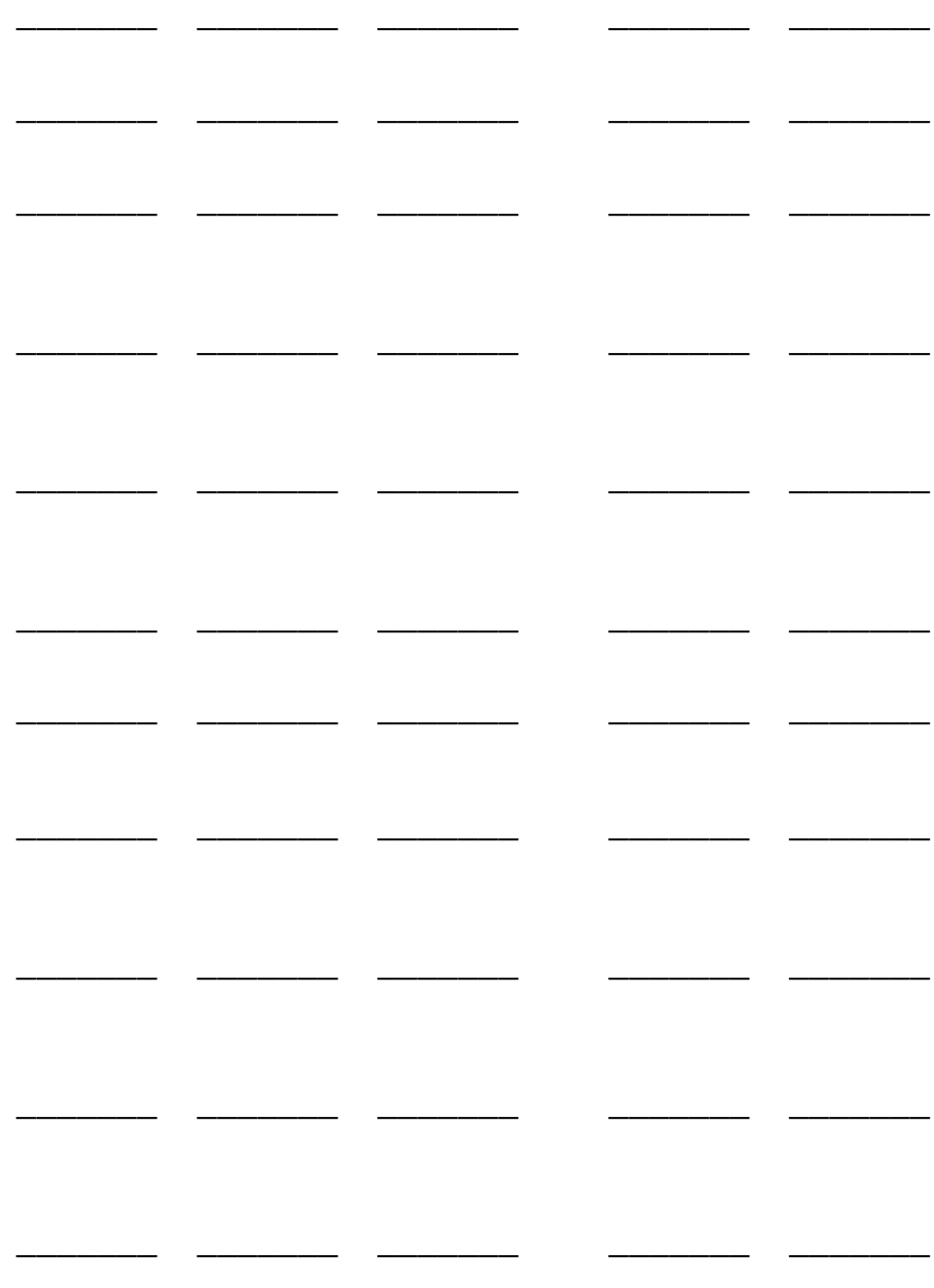

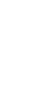




\section{Опросник об отношении детей к стоматологу.}

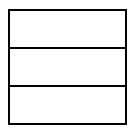

Уважаемые родители! В дальнейшем Вы будете опрошены насчет общих данных о Вашей семье и более подробной информации о прежнему опыту с зубными и другими врачами, об отношении к здоровью зубов и о поведении в разных жизненных ситуациях Вашего ребёнка, а также о стрессе в Вашей семьи в последнем году. Ваши ответы помогут лучше понять ощущения и поведение Вашего ребёнка у стоматолога. Пожалуйста, внимательно прочтите вопросы и отметьте крестиком (х) тот ответ, который лучше всего характеризует ощущения Вашего ребёнка у стоматолога. В отдельных вопросах, где указано, можно отметить несколько ответов.

\section{I. Общая информация о ребёнке и его семье}

1. Пол ребёнка (отметьте X соответствуюипйвариант): $\square$ девочка $\square$ мальчик

2. Дата рождения /дата, месяц, год/

3. Кто живёт в семье вместе с ребёнком? (отметьте X соответствуюиий вариант):
a) $\square$ мама, b)
b) $\square$ отец, с) $\square$ бабушка,
d) $\square$ дедушка,
е) $\square$ брат, сколько f) $\square$ сестра, сколько g) $\square$ приёмная мама ,
h) $\square$ приёмный отец
i) $\square$ опекун

4. Адоптирован ли Ваш ребёнок или взят в опекунстве? (отметьте X соответствуюиий вариант): $\square$ да $\square$ нет

5. Если на 4. вопрос Вы ответили „да”, как долго он или она живёт в семье? /лет/

6. Теперешнее семейное положение родителей, то есть, они живут (отметьте X coomветствуюиий вариант):
a. $\square$ в браке, живут вместе
b. $\square$ не женаты, живут вместе
c. $\square$ в браке, живут отдельно
d. $\square$ не женаты, живут отдельно
е. $\square$ разведены
f. $\square$ вдова/вдовец

Информация о матери (приёмной матери, опекунще)

7.1. Возраст матери (приёмной матери, опекунши) /вгодах/

8.1. Образование матери (приёмной матери, опекунши):
a) $\square$ основное образование
b) $\square$ основное образование+профтехшкола
c) $\square$ среднее образование
d) $\square$ среднее образование + профтехшкола
е) $\square$ незаконч. высшее образование (мин.1 год)
f) $\square$ высшее образование
g) $\square$ другой вариант

9.1. Занятие матери (приёмной матери, опекунши):

а) усвоенная профессия

b) нынечное занятие

10. Общий уровень доходов семьи:
Информация об отце (приёмном отце, опекуне)

7.2. Возраст отца (приёмного отца, опекуна) /вгодах//

8.2. Образование отца (приёмного отца, опекуна):
a) $\square$ основное образование
b) $\square$ основное образование+профтехшкола
c) $\square$ среднее образование
d) $\square$ среднее образование + профтехшкола
е) $\square$ незаконч. высшее образование (мин.1
год)
f) $\square$ высшее образование
g) $\square$ другой вариант

9.2. Занятие отца (приёмного отца, опекуна) :

a) усвоенная профессия

b) нынечное занятие

a) $\square 50$ и меньше латов на 1 человек в семье

b) $\square$ 51- 100 латов на 1 человек в семье

c) $\square$ 101-200 латов на 1 человек в семье

d) $\square$ 201- 400 латов на 1 человек в семье

е) $\square$ больше 401 латов на 1 человек в семье 
1. Есть ли у ребенка какие-то хронические или постаянные болезни, которые имеют некоторое воздействия (ограничения) на его образ жизни ?
а) $\square$ да
b) $\square$ нет
(укажите,какие именно)

2. Как часто ребенок болеет?
а) $\square$ не чаще, чем 1 раз в год
b) $\square$ 1-3 раза в год
c) $\square$ чаще, чем в 3 раза в год

3. Как часто ребенек обращается к врачам, за исключением стоматологов?
a) $\square$ не чаще, чем 1 раз в год
b) $\square$ 2-4 раза в год
c) $\square$ чаще, чем в 4 раза в год

4. Какое отношение имеет ребенок к врачам и медперсоналу?
а) $\square$ дружественное
b) $\square$ нейтральнное
c) $\square$ осторожное
d) $\square$ тревожное
е) $\square$ другое
(укажите,какое именно)

5. Посещает ли ребёнок врачей, кроме стоматологов ?
a. $\square$ не посещает
b. $\square$ меньше чем 1 раз в год
c. $\square$ минимум 1 раз в год
d. $\square$ 2-3 раза в год
е. $\square$ 4-5 раза в год
f. $\square$ более чем в 6 раз в год

6. Пережил ли ребёнок травматический опыт с врачами, кроме стоматологов?
a) $\square$ да (укажите, сколько раз и в каком возрасте)
b) $\square$ нет

7. Лечился ли ребенок в больнице?
а) $\square$ да
b) $\square$ нет
(укажите, сколько раз и в каком возрасте)

8. Проходил ли ребенок лечение под общим наркозом?
a) $\square$ да
(укажите, сколько раз и в каком возрасте)
b) $\square$ нет

9. Были ли у ребенка какие-либо травмы, требующие неотложного лечения?
а) $\square$ да
b) $\square$ нет
(укажите, сколько раз и в каком возрасте)

\section{III. Лечение зубов у ребёнка}

1. В каком возрасте ребенок впервые попал к стоматологу? Пожалуйста, если возможно, укажите возраст ребенка в годах и месяиах года месяцев

2. Как вы думаете, в каком возрасте должен быть первый визит ребенка к зубному врачу?

3. Впервые к стоматологу Вы обратились:
а. $\square$ чтобы изучить стоматологический кабинет
b. $\square$ направил другой врач
c. $\square$ заметили изменения в зубах ребенка
d. $\square$ из-за зубной боли
е. $\square$ другая причина
(укажите,какая именно)

4. Как часто Вы ходите с ребенком к стоматологу проверить зубы?
a. $\square$ каждое полгода (2 раза в год)
b. $\square$ примерно 1 раз в год
c. $\square$ меньше чем 1 раз в год
d. $\square$ почти не посещали 
5. Когда Вы обычно ведете ребенка к стоматологу?
а. $\square$ каждый год в определенное время
b. $\square$ когда вспомню
c. $\square$ когда замечаю какие-либо изменения в зубах
d. $\square$ когда зуб немного болит или мешает
е. $\square$ при длительной зубной боли, которая непереходит
f. $\square$ не ходим вообще

6. Как Вы подготовливаете ребенка перед визитом у стоматолога?
a. $\square$ просмотриваете и чтите детские книжки на эту тему, обсуждая прочитанное и услышанное
b. $\square$ успакаивая, что стоматолог просто посмотрит на его зубы, ничего не будет делать и ничего не будет болеть
c. $\square$ рассказывая о своем опыте у стоматолога
d. $\square$ вместе с ребенком идём к своему стоматологу
е. $\square$ обещая награду за хорошее поведение у стоматолога
f. $\square$ никак не подготовливаю
g. $\square$ другой ответ

7. Какое лечение ребенок получал до сих пор? Пожалуйста, отметьте все прой-денные виды лечения и, как можно, точнее укажите, в каком возрасте 1.pаз?
а. $\square$ осмотр и / или консультацию
b. $\square$ гигиену зубов
c. $\square$ пломбирование без анестезии
d. $\square$ пломбирование под местной анестезией
е. $\square$ пломбирование под общим наркозом
f. $\square$ удаление зуба без анестезии
g. $\square$ удаление зуба под местной анестезией
h. $\square$ удаление зуба под общим наркозом
i. $\square$ другое лечение

8. До сих пор лечение зубов проходило:
а. $\square$ всегда без трудностей, ребёнок легко сотрудничал
b. $\square$ в основном без трудностей
c. $\square$ в основном с небольшими трудностьями
d. $\square$ почти всегда с трудностьями
е. $\square$ всегда с большими трудностьями

9. Какие эмоции возникают у ребенка перед походом к зубному врачу?
а. $\square$ радость, интерес
b. $\square$ нейтральное, равнодушное отношение
c. $\square$ тревога, беспокойство
d. $\square$ страх, плач
е. $\square$ активный протест и сопротивление
f. $\square$ паника, истерия

10. Был ли у ребенка отрицательный, травматический опыт у стоматолога (например, боль, нечуткое отношение врача)?
а. $\square$ да, какой
b) $\square$ нет

11. Если ребенок имел негативный опыт с зубным, что вы делали следующий раз?
а. $\square$ ходили к гигиенисту
b. $\square$ ходили к тому же стоматологу
c. $\square$ ходили к другому стоматологу или клинику
d. $\square$ лечили под общим наркозом
е. $\square$ не лечили, переждали 
12. Обсуждали ли Вы когда-либо Ваш личный отрицательный опыт у стоматолога (например, боль, методы лечения, нечуткое отношение) в присутствии ребенка?
а) $\square$ да
b) $\square$ нет

13. Приходилось ли Вам когда-нибудь запугивать ребенка стоматологом за провинность?
а. $\square$ нет, никогда
b. $\square$ да, один раз
c. $\square$ да, несколько раз
d. $\square$ да, часто

14. Приходилось ли Вам переложить визит Вашего ребенка к стоматологу по незначительной причине (например, решили сходить в другое место)?
a. $\square$ нет, никогда
b. $\square$ да, один раз
c. $\square$ да, несколько раз
d. $\square$ да, часто

15. Кто из взрослых обычно сопровождает ребенка к стоматологу?
а. $\square$ только мама
b. $\square$ только отец
c. $\square$ у которого есть время
d. $\square$ тот кто не боится
е. $\square$ которого слушается
f. $\square$ любой из взрослых членов семьи

16. В какое время дня Вы обычно ведете ребенка к стоматологу?
a. $\square$ обычно в первой половине дня
b. $\square$ обычно после обеда, после детского сада / школы
c. $\square$ обычно вечером, после работы
d. $\square$ в разные времена дня

\section{IV. Отночение ребёнка к здоровью зубов}

1. Как часто ваш ребенок чистить зубы?
а. $\quad \square$ каждый день по крайней мере в 2 раза
b. $\square$ каждый день по крайней мере в 1 раза
c. $\square$ нерегулярно, но несколько раз в неделю
d. $\square$ нерегулярно, но несколько раз в месяц

2. Проверяете ли Вы зубы ребенка после очистки?
a) $\square$ да
b) $\square$ нет

3. Как Ваш ребенок воспринимает чистку зубов каждый день?
a. $\square$ как должное и нужное, с понятием
b. $\square$ как долг
c. $\square$ избегает чистки
d. $\square$ отказывается, но чистит в присутствии взрослых
е. $\square$ отказывается даже в присутствии взрослых

4. Принимает ли Ваш ребенок таблетки фтора?
а. $\square$ да, регулярно
b. $\square$ да, но нерегулярно
c. $\square$ ранее принимал, в настоящее время уже нет
d. $\square$ не принимает и никогда не принимал 
5. Где Вы обретаете информацию об уходом за зубами ребенка?
a. $\square$ у детского врача / у семейного врача
b. $\square$ у стоматолога
c. $\square$ у зубного гигиениста
d. $\square$ из средств массовой информации (газеты, журналы, телевидение, радио, веб-сайты и т.д.)
е. $\square$ у друзей и знакомых
f. $\square$ нигде не обретаете
g. $\square$ другой ответ

6. Где получаете информацию о подготовке ребенка для визита к стоматологу?
а. $\square$ у детского врача / у семейного врача
b. $\square$ у стоматолога
c. $\square$ у зубного гигиениста
d. $\square$ из средств массовой информации (газеты, журналы, телевидение, радио, веб-сайты и т.д.)
е. $\square$ у друзей и знакомых
f. $\square$ нигде не обретаете
g. $\square$ другой ответ

\section{V. Характеристика поведения ребенка}

1. Пожалуйста, прочтите вопросы и оцените в 10-балловой шкале, в какой мере Вашему ребёнку характерны следующие качества (в полюсах крайние проявление качеств):

а. общительность

$\begin{array}{llllllllllll}\text { Предпочетает } & 1 & 2 & 3 & 4 & 5 & 6 & 7 & 8 & 9 & 10 & \text { Охотно бывает } \\ \text { одиночество } & \square & \square & \square & \square & \square & \square & \square & \square & \square & \square & \text { в обществе }\end{array}$

b. активность

$\begin{array}{llllllllllll}\text { Не активен, } & 1 & 2 & 3 & 4 & 5 & 6 & 7 & 8 & 9 & 10 & \text { Активно } \\ \text { быстро устаёт } & \square & \square & \square & \square & \square & \square & \square & \square & \square & \square & \text { действует весь }\end{array}$

с. импульсивность

$\begin{array}{llllllllllll}\text { Может долго } & 1 & 2 & 3 & 4 & 5 & 6 & 7 & 8 & 9 & 10 & \text { Беспрерывно } \\ \text { заниматься чем- } & \square & \square & \square & \square & \square & \square & \square & \square & \square & \square & \begin{array}{l}\text { переключается } \\ \text { то одним }\end{array}\end{array}$

d. эмоциональная лабильность

$\begin{array}{llllllllllll}\text { Очень спокой- } & 1 & 2 & 3 & 4 & 5 & 6 & 7 & 8 & 9 & 10 & \text { Мгновенно } \\ \text { ный, уровно- } & & & & & & & & & \\ \text { веагирует на }\end{array}$

e. эмоциональность

$\begin{array}{llllllllllll}\text { Не выра- } & 1 & 2 & 3 & 4 & 5 & 6 & 7 & 8 & 9 & 10 & \text { Эмоции очень } \\ \text { жает } & \square & \square & \square & \square & \square & \square & \square & \square & \square & \square & \text { яркие, заметные }\end{array}$
эмоции

f. стеснительность

$\begin{array}{llllllllllll}\text { Медленно } & 1 & 2 & 3 & 4 & 5 & 6 & 7 & 8 & 9 & 10 & \text { Быстро } \\ \text { осваевается к } & & & & & & & & & \\ \text { новым осваевается к } \\ \text { ниям }\end{array}$




\section{2. Легко ли раздражителен Ваш ребенок?}
а. $\square$ в основном да
b. $\square$ зависит от ситуации
c. $\square$ в основном нет
d. $\square$ почти не раздражается

3. Может ли Ваш ребенок сам справится с тревогой / стрессом, успокоиться?
а. $\square$ в основном да
b. $\square$ зависит от ситуации
c. $\square$ в основном нет
d. $\square$ не спраляется вообще

4. Как долго ребенок переживает тревожные события или опыт?
а. $\square$ несколько минут
b. $\square$ несколько часов
c. $\square$ один день
d. $\square$ несколько дней

5. Что, по Вашему мнению является самым неприятным, тревожным опытом в жизни ребенка? В каком возрасте это произошло?

6. Как Вы обычно успокаевете ребенка, когда он / она расстроился или боится?
a. $\square$ поласкаете
b. $\square$ обсуждаете более подробно
c. $\square$ привлекаете внимание ребенка на что-нибудь другое
d. $\square$ говорите, чтоб не волнавался
е. $\square$ ничего особенного неговорите
f. $\square$ другой ответ

7. Как Вы обычно успокаевете ребенка, когда он / она грустит?
a. $\square$ поласкаете
b. $\square$ обсуждаете более подробно
c. $\square$ привлекаете внимание ребенка на что-нибудь другое
d. $\square$ говорите, чтоб не волнавался
е. $\square$ ничего особенного неговорите
f. $\square$ другой ответ

8. Как Вы обычно готовитесь к ответственному или тревожному событию?
a. $\square$ более подробно обсуждаете предстоящие события
b. $\square$ подбадриваете и похваливаете
c. $\square$ говорите, чтоб не волнавался
d. $\square$ ничего особенного неговорите
е. $\square$ другой ответ

9. Боится ли Ваш ребенок (можно отметить несколько ответов):
а. $\square$ высоты
b. $\square$ закрытых помещений
c. $\square$ оставаться одному
d. $\square$ пауков / насекомых
е. $\square$ неизвестных животных
f. $\square$ темноты
g. $\square$ незнакомых людей
h. $\square$ чего-то/кого-то другого 


\section{VI. Стресс и его преодоление}

1. Пережила ли Ваша семья в течении в последнего года любое из далее названных событий (можно отметить несколько ответов):
a. смерть супруга или другого члена семьи
b. развод, распад семьи
c. ухудшение здоровья члена семьи
d. появление нового члена семьи
е. переезд в другое место жительство детей или других членов семьи
f. серёзные ссоры в семье

2. Пережили ли Вы лично в течении в последнего года любое из далее названных событий (можно отметить несколько ответов) :
а. тяжелая болезнь
b. заметные изменения в условиях жизни
c. проблемы с властями
d. смерть / изменения отношения близкого друга
е. смена места жительства
f. нарушение сна / бессонница
g. отпуск

3. Пережили ли Вы в течении в последнего года любое из далее названных событий на работе любое из далее названных событий (можно отметить несколько ответов):
a. уход на пенсию
b. увольнение с работы
c. смена работы
d. изменения в карьере (повышение)
е. конфликт с начальством
f. изменения в микроклимате / условий работы

Спасибо за сотрудничество! 